\title{
Review of Industry Efforts To Manage Pressurized Water Reactor Feedwater Nozzle, Piping, and Feedring Cracking and Wall Thinning
}

Manuscript Completed: March 1997

Date Published: March 1997

Prepared by

V. N. Shah, A. G. Ware, A. M. Porter

Idaho National Engineering Laboratory Lockheed Idaho Technologies Company

Idaho Falls, ID 83415-3129

E. J. Brown, NRC Technical Monitor

E. A. Trager, NRC Project Manager

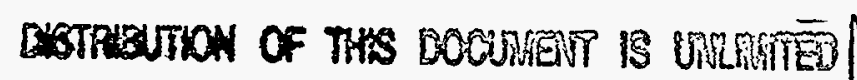

Prepared for

Safety Programs Division

Office for Analysis and Evaluation of Operational Data

U.S. Nuclear Regulatory Commission

Washington, DC 20555-0001

NRC Job Code E8238

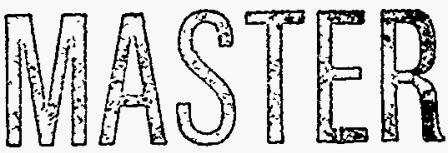




\title{
UNITED STATES \\ NUCLEAR REGULATORY COMMISSION \\ WASHINGTON, D.C. 20555-0001
}

TO ALL RECIPIENTS:

\author{
SUBJECT: "REVIEW OF INDUSTRY EFFORTS TO MANAGE PRESSURIZED WATER \\ REACTOR FEEDWATER NOZZLE, PIPING, AND FEEDRING CRACKING AND \\ WALL THINNING," NUREG/CR-6456 (INEL 96/0089)
}

Attached for your information and use is a copy of the report, "Review of Industry Efforts to Manage Pressurized Water Reactor Feedwater Nozzle, Piping, and Feedring Cracking and Wall Thinning," NUREG/CR-6456. The study objective was to provide a comprehensive overview document discussing pressurized-water reactor (PWR) feedwater nozzle, piping, and feedring cracking and wall thinning; safety aspects; and industry actions taken to manage these issues. The report should be useful in identifying, assessing, and evaluating program options to manage these issues. The time frame spans from initial discovery of feedwater nozzle cracking in 1979 through 1996.

The review and assessment effort covers relevant field experience with PWR feedwater systems, the factors causing the damage, design modifications, operating procedure changes, augmented inspection programs, and repair and replacement activities carried out because of the degradation that occurred. The effort focused on the feedwater system adjacent to the feedwater nozzle where fatigue cracking and wall thinning had been reported. This includes the main and auxiliary feedwater piping adjacent to the feedwater nozzle, and the thermal sleeve, feedring, and J-tubes. The principal areas reviewed were (1) feedwater system design, (2) safety significance of feedwater line rupture, (3) fatigue cracking experience, (4) flow-accelerated corrosion-induced wall thinning experience, (5) steam generator water hammer damage experience, (6) degradation mechanisms, (7) inservice inspection methods, and (8) mitigation, monitoring, and replacement activities.

This effort emphasized understanding the technical aspects for each area in order to assess the impact on managing (establish confidence that limits for safe operation are maintained) degradation of these components. In this context, the study concentrates on causes, mechanisms, conditions (temperature, pressure, environment, etc.), inspections, procedures, and corrective actions from the perspective of capability to assess a specific aspect such as crack characterization. Thus, the report is directed toward determining whether current technology is sufficient to "manage the problem".

The operating experience review addressed feedwater nozzle cracking caused by thermal fatigue; flow-accelerated corrosion wall thinning of carbon steel J-tubes, feedrings, and thermal sleeves in top-feed steam generators, and auxiliary feedwater lines in preheat steam generators; and water hammer damage in both types of steam generators. Feedwater nozzle cracking was detected in 18 PWRs from 1979 through 1983. These were found as a result of IE Bulletin 79-13, "Cracking in Feedwater System Piping," 1979. 
There was approximately one event per year from 1983 until bulletin closure in 1991. The nozzle cracking event frequency increased to six per year for 1992 and 1993 but no additional events were detected from then through 1996. It appears that licensee action has been sufficient to minimize flow-accelerated wall thinning in J-tubes and auxiliary feedwater lines and while wall thinning in feedrings and thermal sleeves was not addressed by specific action, there was evidence of visual inspection and repair when needed. Similarly, it appears that licensees have taken sufficient action, primarily design modifications and operating procedure changes, to minimize water hammer events. There were 28 events reported during the 1970s, 6 during the 1980s, and none after that.

The technical findings as a whole indicate that appropriate analysis, inspection, monitoring, mitigation (including operational procedures), and replacement techniques have been developed so that thermal fatigue and flow-accelerated corrosion damage to feedwater nozzles, piping, and feedrings can be managed effectively. This simply means the tools are available to manage. However, this managing process requires detailed knowledge about component and system design, construction, and materials; cognizance of operating procedures (especially the potential for extended operation at startup or hot standby with automatic auxiliary feedwater control); in-depth understanding of factors that cause thermal fatigue and flow-accelerated corrosion; and adequate training in the use of predictive analysis methods and advanced inspection techniques. The staff at several PWR plants have been proactive in managing this type of damage.

An overview observation from the study is that plant specific aspects control both the degree of susceptibility and the appropriate solution scheme to "manage the problem". Therefore, plant specific solutions would be anticipated as the rule rather than a generic program.

The Office of Nuclear Reactor Regulation and Office of Nuclear Regulatory Research provided review comments on drafts of this report. In addition, comments were received from technical experts who provided information during plant visits or information in the technical literature. The organizations included were the Tennessee Valley Authority, Southern California Edison, Pacific Gas and Electric, Westinghouse Electric, and Electric Power Research Institute.

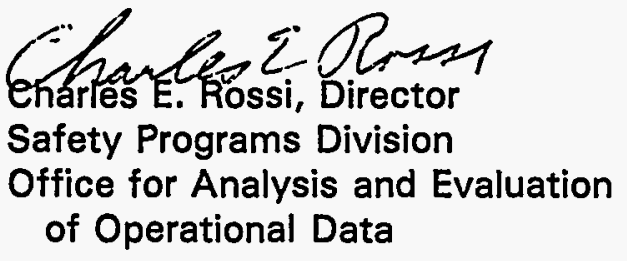




\section{ABSTRACT}

This report presents our review of the nuclear industry efforts to manage thermal fatigue, flow-accelerated corrosion, and water hammer damage to pressurized water reactor (PWR) feedwater nozzles, piping, and feedrings. The review includes an evaluation of design modifications, operating procedure changes, augmented inspection and monitoring programs, and mitigation, repair and replacement activities. Four specific actions were taken to perform the evaluation: (a) review of field experience to identify trends of operating events, (b) review of related technical literature, (c) visits to three PWR plants and a PWR vendor, and (d) solicitation of information from eight other countries.

The characteristics and safety implications of the damage caused by flow stratification-induced thermal fatigue are different than those caused by flow-accelerated corrosion. Thermal fatigue cracking has generally occurred in a relatively local, safety-related portion of the feedwater piping inside the containment, whereas wall-thinning caused by flow-accelerated corrosion has typically occurred, with few exceptions, in the nonsafety-related balance of plant piping outside the containment. Field experience has shown that through-wall thermal fatigue cracks in the feedwater nozzles and piping have leaked and provided warning, whereas a component damaged by flow-accelerated corrosion loses its strength and can fail catastrophically without warning during normal operation.

The factors causing thermal fatigue and flow-accelerated corrosion are well understood. Inservice inspection techniques are available for reliable detection and accurate sizing of thermal fatigue cracks. Costeffective radiographic techniques for measuring wall thinning are being developed. Modifications in the plant operating procedures and the feedwater system designs have been made to mitigate thermal fatigue damage. Optimized water chemistry has been developed for mitigating flow-accelerated corrosion damage to both single- and two-phase portions of the PWR secondary systems. Corrosion resistant materials are used to replace the carbon steel components damaged by flow-accelerated corrosion.

Our assessment of field experience is that the USNRC licensees have apparently taken sufficient action to minimize the feedwater nozzle cracking caused by thermal fatigue and the wall thinning of J-tubes and feedwater piping. However, we did not find specific industry actions to minimize the wall-thinning in feedrings and thermal sleeves, but we found visual inspection being performed and repair when needed.

Our assessment of field experience also indicates that the USNRC licensees have taken sufficient action to minimize steam generator water hammer in both top-feed and preheat steam generators. However, we have not evaluated the industry efforts to minimize multiple check valve failures that have allowed backflow of steam from a steam generator and have played a major role in several steam generator water hammer events.

A major finding of this review is that analysis, inspection, monitoring, mitigation, and replacement techniques have been developed for managing thermal fatigue and flow-accelerated corrosion damage to feedwater nozzles, piping, and feedrings. Adequate training and appropriate applications of these techniques would ensure effective management of this damage. Several PWR plant operators have been proactive in managing this damage. 


\section{DISCLAIMER}

Portions of this document may be illegible in electronic image products. Images are produced from the best available original document. 


\section{DISCLAIMER}

This report was prepared as an account of work sponsored by an agency of the United States Government. Neither the United States Government nor any agency thereof, nor any of their employees, make any warranty, express or implied, or assumes any legal liability or responsibility for the accuracy, completeness, or usefulness of any information, apparatus, product, or process disclosed, or represents that its use would not infringe privately owned rights. Reference herein to any specific commercial product, process, or service by trade name, trademark, manufacturer, or otherwise does not necessarily constitute or imply its endorsement, recommendation, or favoring by the United States Government or any agency thereof. The views and opinions of authors expressed herein do not necessarily state or reflect those of the United States Government or any agency thereof. 


\section{CONTENTS}

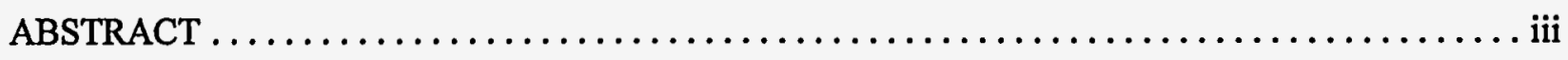

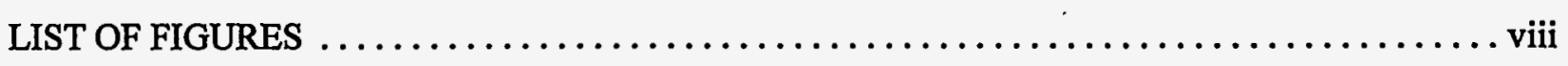

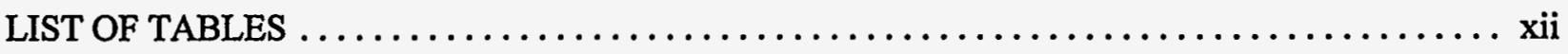

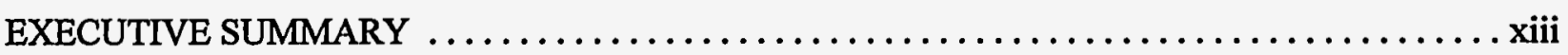

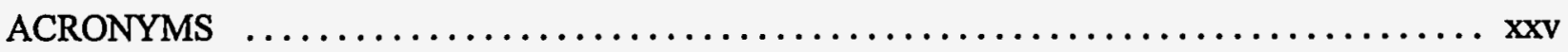

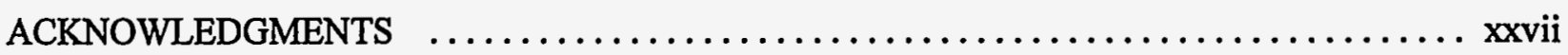

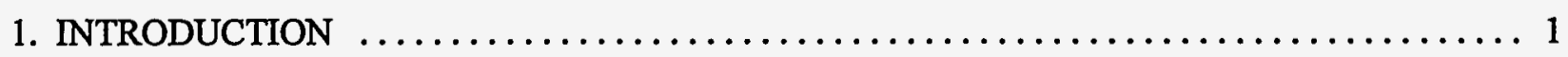

2. MAIN AND AUXILIARY FEEDWATER SYSTEM DESCRIPTIONS $\ldots \ldots \ldots \ldots \ldots \ldots \ldots 4$

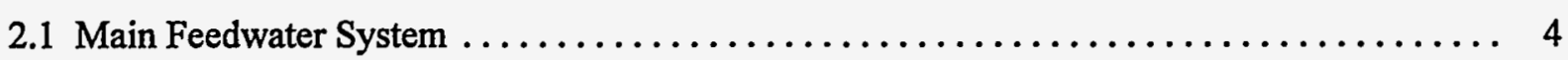

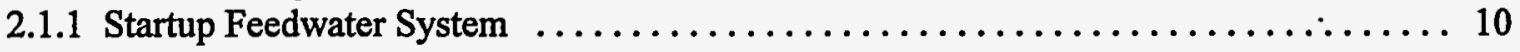

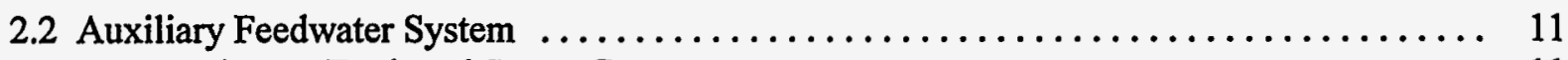

2.2.1 Preheater-Equipped Steam Generators $\ldots \ldots \ldots \ldots \ldots \ldots \ldots \ldots \ldots \ldots \ldots \ldots \ldots \ldots$

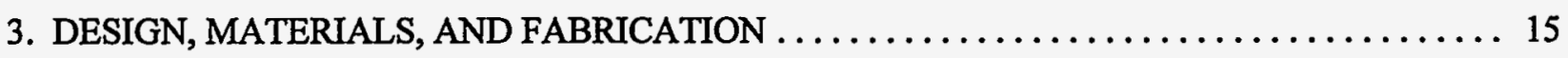

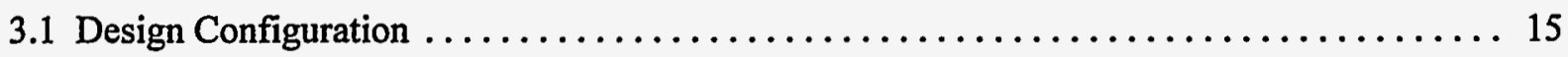

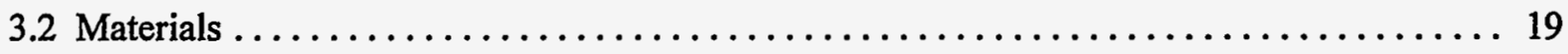

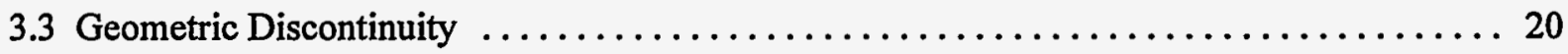

4. OPERATING TRANSIENTS AND ENVIRONMENT $\ldots \ldots \ldots \ldots \ldots \ldots \ldots \ldots \ldots \ldots \ldots \ldots$

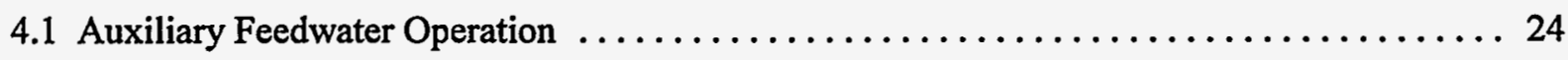

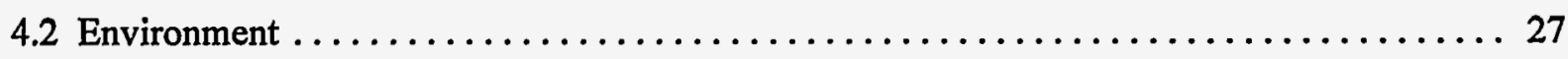

5. THE SAFETY SIGNIFICANCE OF FEEDWATER LINE RUPTURE $\ldots \ldots \ldots \ldots \ldots \ldots \ldots 29$

6. FIELD EXPERIENCE RELATED TO CRACKING AND WALL THINNING OF FEEDWATER NOZZLES, PIPING, AND FEEDRINGS $\ldots \ldots \ldots \ldots \ldots \ldots \ldots \ldots \ldots \ldots \ldots \ldots$

6.1 Initial Discoveries of Fatigue Cracking $\ldots \ldots \ldots \ldots \ldots \ldots \ldots \ldots \ldots \ldots \ldots \ldots \ldots \ldots \ldots \ldots, 32$ 
6.2 Crack Discoveries Between Initial Inspections and Bulletin Closeout $\ldots \ldots \ldots \ldots \ldots \ldots$

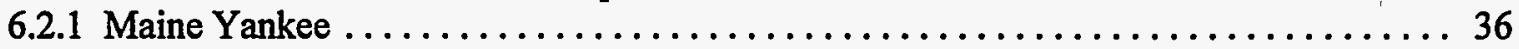

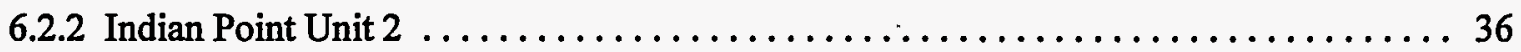

6.3 Fatigue Cracking After Bulletin Closeout $\ldots \ldots \ldots \ldots \ldots \ldots \ldots \ldots \ldots \ldots \ldots \ldots \ldots . \ldots 1$

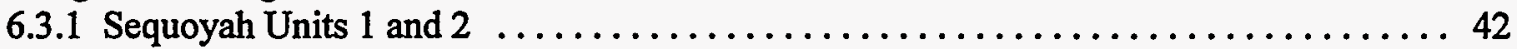

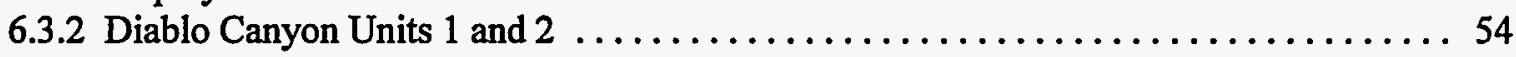

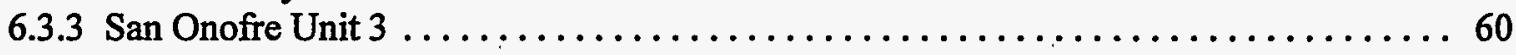

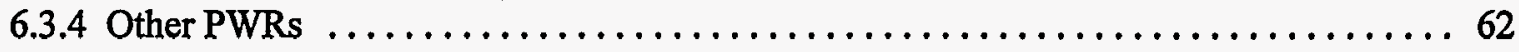

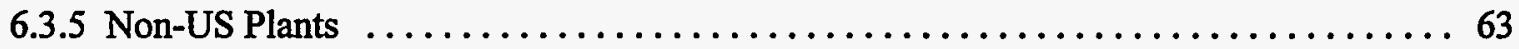

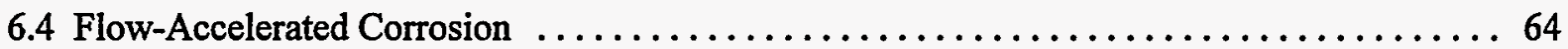

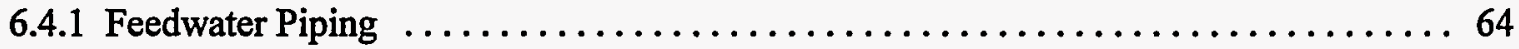

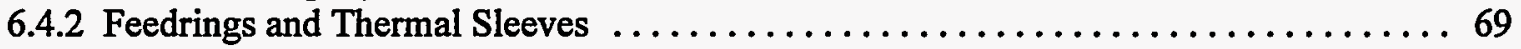

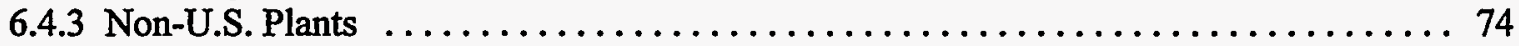

6.5 Steam Generator Water Hammer Damage $\ldots \ldots \ldots \ldots \ldots \ldots \ldots \ldots \ldots \ldots \ldots \ldots$

6.5.1 Steam Generator Water Hammer Phenomenon $\ldots \ldots \ldots \ldots \ldots \ldots \ldots \ldots \ldots \ldots$

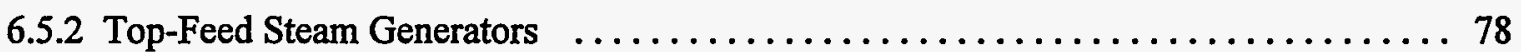

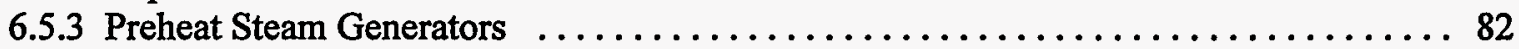

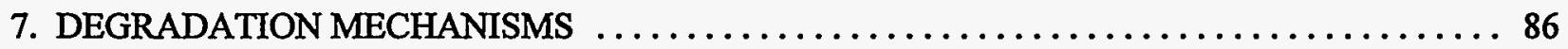

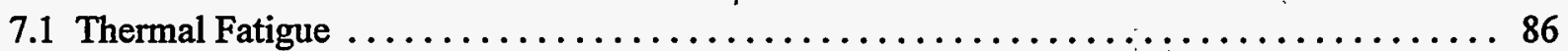

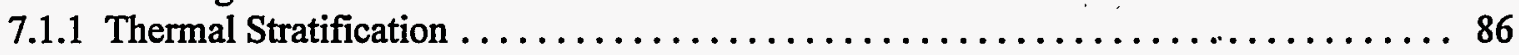

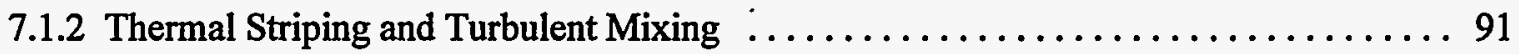

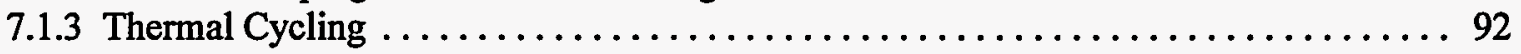

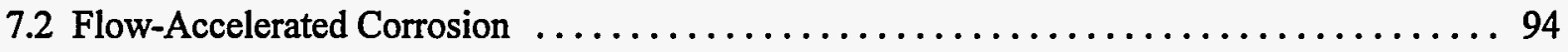

7.2.1 Flow-Accelerated Corrosion Phenomena ....................... 94

7.2.2 Factors Affecting Flow-Accelerated Corrosion $\ldots \ldots \ldots \ldots \ldots \ldots \ldots \ldots \ldots$

8. INSERVICE INSPECTION OF PRESSURIZED WATER REACTOR

FEEDWATER NOZZLES AND PIPING $\ldots \ldots \ldots \ldots \ldots \ldots \ldots \ldots \ldots \ldots \ldots \ldots \ldots \ldots \ldots \ldots$

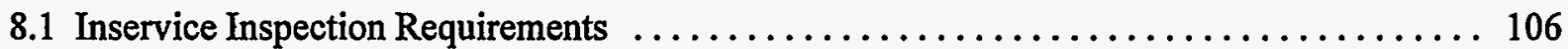

8.1.1 Fabrication, Preservice Inspection, and Inservice Inspection Requirements . . . . . 106

8.1.2 Inspections in Response to IE Bulletin $79-13 \ldots \ldots \ldots \ldots \ldots \ldots \ldots \ldots \ldots \ldots$

8.1.3 Activities Since Close-out of IE Bulletin $79-13 \ldots \ldots \ldots \ldots \ldots \ldots \ldots \ldots \ldots$

8.2 Advancements for Inservice Inspection of Fatigue Cracks $\ldots \ldots \ldots \ldots \ldots \ldots \ldots$

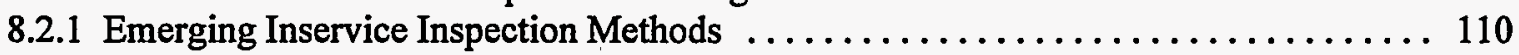

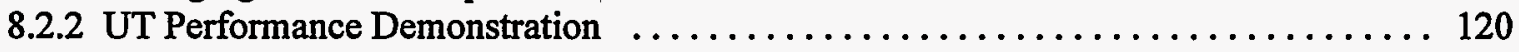

8.2.3 Risk-based Inspection (ASME Section XI Code Case) .............. 121

8.3 Inservice Inspection of Wall Thinning Caused by Flow-Accelerated Corrosion $\ldots \ldots \ldots 121$

8.3.1 Inspection in Response to Bulletin 87-01 ..................... 122

8.3.2 Emerging Inservice Inspection Methods for Wall Thinning $\ldots \ldots \ldots \ldots \ldots \ldots \ldots 123$

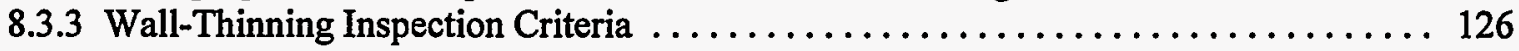

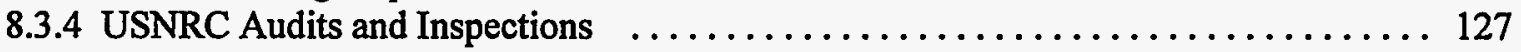




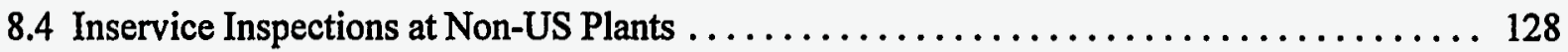

8.4.1 Inservice Inspections of Fatigue Cracks at Non-US Plants $\ldots \ldots \ldots \ldots \ldots \ldots \ldots \ldots$

8.4.2 Inservice Inspections of Wall Thinning at Non-US Plants $\ldots \ldots \ldots \ldots \ldots \ldots \ldots 129$

9. MITIGATION AND MONITORING OF FATIGUE, FLOW-ACCELERATED CORROSION, AND WATER HAMMER DAMAGE $\ldots \ldots \ldots \ldots \ldots \ldots \ldots \ldots \ldots \ldots \ldots \ldots \ldots \ldots \ldots \ldots$

9.1 Mitigation of Thermal Fatigue Damage $\ldots \ldots \ldots \ldots \ldots \ldots \ldots \ldots \ldots \ldots \ldots \ldots \ldots \ldots \ldots \ldots$

9.2 Fatigue Monitoring of Feedwater Lines $\ldots \ldots \ldots \ldots \ldots \ldots \ldots \ldots \ldots \ldots \ldots \ldots \ldots \ldots$

9.3 Mitigation of Flow-Accelerated Corrosion Damage $\ldots \ldots \ldots \ldots \ldots \ldots \ldots \ldots \ldots \ldots$

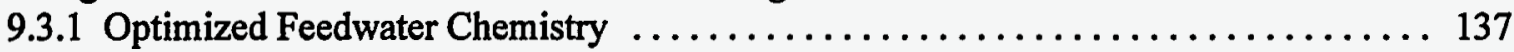

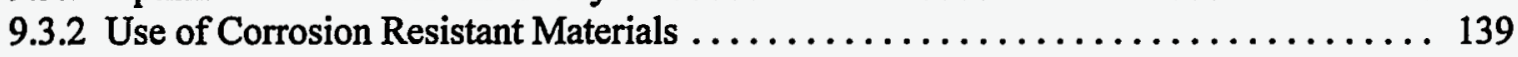

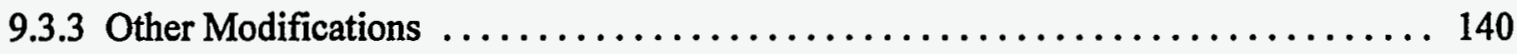

9.4 Mitigation of Water Hammer Damage $\ldots \ldots \ldots \ldots \ldots \ldots \ldots \ldots \ldots \ldots \ldots \ldots \ldots$

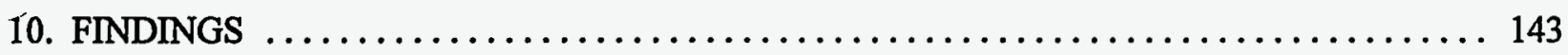

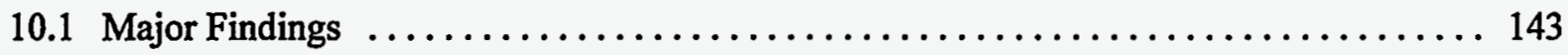

10.2 Specific Findings - Degradation Mechanisms $\ldots \ldots \ldots \ldots \ldots \ldots \ldots \ldots \ldots \ldots \ldots \ldots$

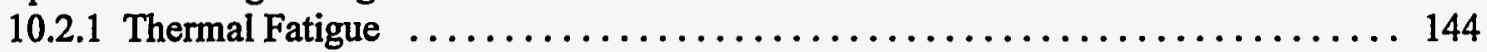

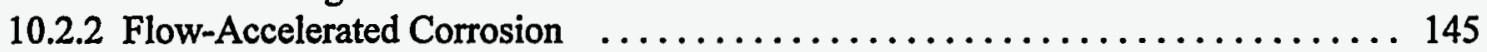

10.3 Specific Findings - Inservice Inspections $\ldots \ldots \ldots \ldots \ldots \ldots \ldots \ldots \ldots \ldots \ldots \ldots \ldots$

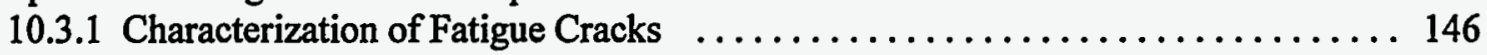

10.3.2 Characterization of Wall Thinning $\ldots \ldots \ldots \ldots \ldots \ldots \ldots \ldots \ldots \ldots \ldots \ldots \ldots \ldots \ldots \ldots \ldots \ldots \ldots$

10.4 Specific Findings - Mitigation, Monitoring, Repair, and Replacement $\ldots \ldots \ldots \ldots 147$

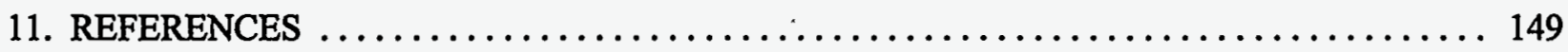

APPENDIX - Questionnaire Submitted to Foreign Countries $\ldots \ldots \ldots \ldots \ldots \ldots \ldots \ldots \ldots$ A-1 


\section{LIST OF FIGURES}

1. Sketch of a portion of the PWR feedwater system and its components

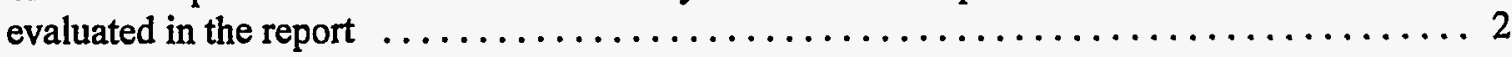

2. Schematic of a typical main feedwater system for a Westinghouse 4-loop plant

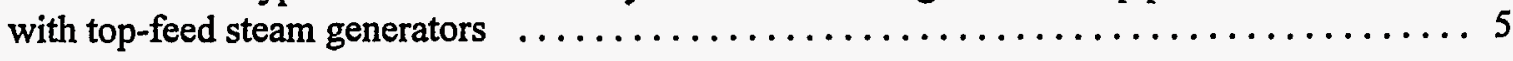

3. Sketch of a recirculating steam generator without a preheater $\ldots \ldots \ldots \ldots \ldots \ldots \ldots \ldots$

4. Sketch of a recirculating steam generator with a preheater $\ldots \ldots \ldots \ldots \ldots \ldots \ldots \ldots$

5. Top view of Diablo Canyon feedring $\ldots \ldots \ldots \ldots \ldots \ldots \ldots \ldots \ldots \ldots \ldots \ldots \ldots$

6. Schematic of a typical main feedwater system for a Babcock \& Wilcox plant ......... 8

7. Cross-section of a Babcock \& Wilcox once-through steam generator with external

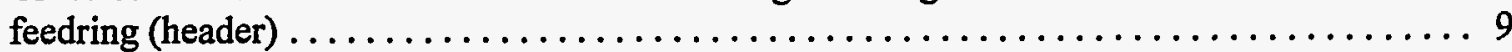

8. Schematic of an auxiliary feedwater system for a 4-loop Westinghouse plant with

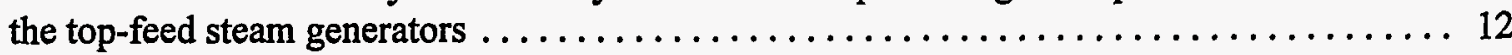

9. Schematic of a feedwater system for a Westinghouse plant with steam

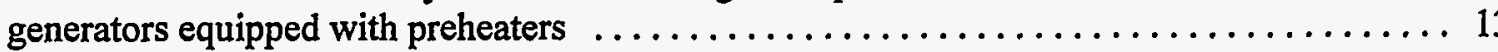

10. 90-degree elbow joining feedwater nozzle and piping in the original

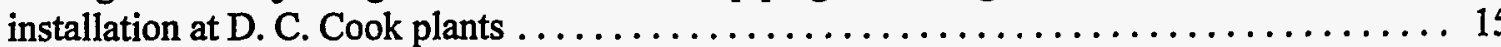

11. Expander joining feedwater nozzle and piping at the San Onofre 1 plant $\ldots \ldots \ldots \ldots$

12. Sketch of a feedwater nozzle at a typical Combustion Engineering plant $\ldots \ldots \ldots \ldots \ldots$

13. Modified feedwater nozzle and piping configuration at D. C. Cook plant $\ldots \ldots \ldots \ldots 17$

14. San Onofre Units 2 and 3 feedwater distribution piping $\ldots \ldots \ldots \ldots \ldots \ldots \ldots \ldots \ldots$

15. Typical PWR feedwater nozzle-to-pipe weld with a counterbore $\ldots \ldots \ldots \ldots \ldots \ldots$

16. Construction drawing of transition piece for Sequoyah Units 1 and $2 \ldots \ldots \ldots \ldots \ldots \ldots 21$

17. Construction drawings for feedwater nozzle and piping welds at

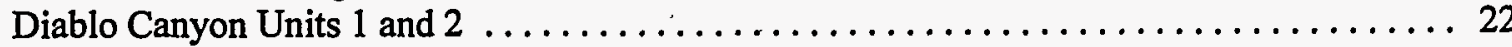

18. Geometric discontinuity introduced by the field welding between the feedwater nozzle and the transition piece 
19. Flow stratification in PWR feedwater nozzle during low flow conditions $\ldots \ldots \ldots \ldots 25$

20. Auxiliary feedwater flow for Sequoyah Unit 1 showing automatic and manual controls .... 26

21. Auxiliary feedwater flow for Sequoyah Unit 2 showing automatic and manual controls . . . . 27

22. Typical fatigue crack orientation at feedwater nozzle counterbore $\ldots \ldots \ldots \ldots \ldots \ldots$

23. Locations of thermal fatigue cracks in an Indian Point Unit 2 feedwater nozzle and steam generator shell caused by bypass leakage of cold feedwater $\ldots \ldots \ldots \ldots \ldots \ldots \ldots$

24. Indian Point Unit 2 feedwater nozzle sealing sleeve installed to prevent

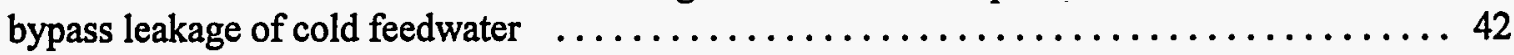

25. Stratified flows during operation of auxiliary feedwater system $\ldots \ldots \ldots \ldots \ldots \ldots \ldots$

26. Through-wall crack in the feedwater nozzle weld at Sequoyah Unit $1 \ldots \ldots \ldots \ldots$

27. Extent and orientation of primary cracks in feedwater nozzle-to-transition field weld at Sequoyah Units 1 and 2 found in $1992 \ldots \ldots \ldots \ldots \ldots \ldots \ldots \ldots \ldots$

28. Direction of propagation of a primary crack at Sequoyah Unit $1 \ldots \ldots \ldots \ldots \ldots$

29. Loop 1 auxiliary feedwater flow rates during manual and automatic operation at Sequoyah Unit 1 on November $29,1994 \ldots \ldots \ldots \ldots \ldots \ldots \ldots \ldots \ldots \ldots$

30. New thermal liner protecting the feedwater nozzle and elbow from

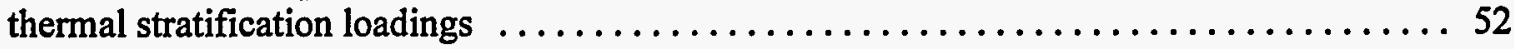

31. Weld buildup to eliminate counterbore as a stress raiser $\ldots \ldots \ldots \ldots \ldots \ldots \ldots \ldots \ldots \ldots$

32. Feedwater nozzle area layout at Diablo Canyon Units 1 and $2 \ldots \ldots \ldots \ldots \ldots \ldots$

33. Temperatures and flow rate during cooldown on $9 / 13 / 92$ at Diablo Canyon

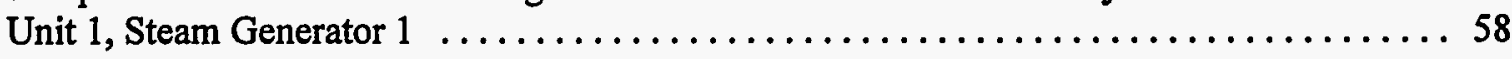

34. Distribution of axial stresses in a long horizontal feedwater piping for two different elevations of hot-and-cold coolant interface and for two different boundary conditions for the pipe ends $\ldots \ldots \ldots \ldots \ldots \ldots \ldots \ldots \ldots \ldots \ldots \ldots \ldots \ldots$

35. San Onofre Units 2 and 3 feedwater nozzle region $\ldots \ldots \ldots \ldots \ldots \ldots \ldots \ldots \ldots \ldots \ldots$

36. Surry feedwater pipe rupture caused by flow-accelerated corrosion $\ldots \ldots \ldots \ldots \ldots \ldots$

37. Changes in the Diablo Canyon J-tube design to mitigate flow-accelerated

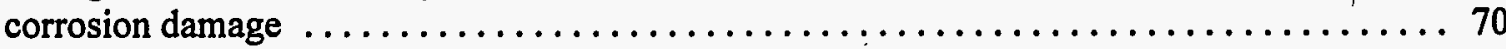


38. A redesigned feedwater nozzle-to-piping connection at Diablo Canyon Units 1 and $2 \ldots \ldots 72$

39. Loviisa Unit 1 feedwater pipe rupture caused by flow-accelerated corrosion $\ldots \ldots \ldots \ldots 74$

40. Sequence of events leading to water hammer $\ldots \ldots \ldots \ldots \ldots \ldots \ldots \ldots \ldots \ldots \ldots \ldots$

41. Older vintage feedring design for top-feed steam generators $\ldots \ldots \ldots \ldots \ldots \ldots \ldots \ldots$

42. Main and auxiliary feedwater systems for KRSKO $\ldots \ldots \ldots \ldots \ldots \ldots \ldots \ldots \ldots$

43. KRSKO Loop 2 auxiliary feedwater line $\ldots \ldots \ldots \ldots \ldots \ldots \ldots \ldots \ldots \ldots \ldots$

44. Thermal stresses in a pipe with stratified flow $\ldots \ldots \ldots \ldots \ldots \ldots \ldots \ldots \ldots \ldots \ldots$

45. Fatigue data for SA-106 Grade B carbon steel smooth base metal specimens in air

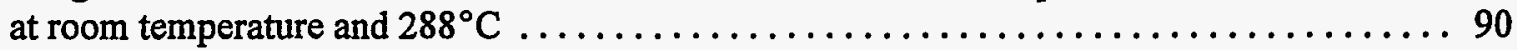

46. Turbulence interaction regions $\ldots \ldots \ldots \ldots \ldots \ldots \ldots \ldots \ldots \ldots \ldots \ldots \ldots \ldots \ldots \ldots \ldots \ldots \ldots \ldots \ldots$

47. A change in the penetration depth of turbulence from power variations can cause thermal stratification and cycling in a branch line $\ldots \ldots \ldots \ldots \ldots . .93$

48. The flow-accelerated corrosion model $\ldots \ldots \ldots \ldots \ldots \ldots \ldots \ldots \ldots \ldots \ldots \ldots \ldots$

49. Flow and temperature dependence of flow-accelerated corrosion rates $\ldots \ldots \ldots \ldots \ldots$

50. Influence of fluid temperature on flow-accelerated corrosion rates for carbon steel fittings estimated using the Chexal-Horowitz model . . . . . . . . . . . 98

51. Influence of fluid velocity on flow-accelerated corrosion rates for a 90-degree carbon steel elbow, estimated using the Chexal-Horowitz model

52. Influence of chromium content on flow-accelerated corrosion rates for a 90-degree carbon steel elbow, estimated using the Chexal-Horowitz model $\ldots \ldots \ldots \ldots \ldots 100$

53. The calculated influence of the temperature on the ferrous ion concentration

54. Influence of dissolved oxygen content on flow-accelerated corrosion rates for a 90-degree carbon steel elbow, estimated using the Chexal-Horowitz model . . . . . 102

55. Effect of cold $\mathrm{pH}$ on solubility of magnetite in deoxygenated water $\ldots \ldots \ldots \ldots \ldots$

56. Influence of cold $\mathrm{pH}$ on flow-accelerated corrosion rates for a 90-degree carbon steel elbow, estimated using the Chexal-Horowitz model

57. Typical PWR feedwater nozzle-to-pipe weld with geometric discontinuity (counterbore) and cracking outside the Code examination volume 
58. Probability of detection versus depth of thermal fatigue cracks in clad ferritic and cast austenitic pipe and of IGSCC cracks in wrought austenitic pipe - piping inspection round robin results

59. Depth of thermal fatigue cracks in clad ferritic material as estimated by the six inservice inspection teams with the conventional UT techniques versus that estimated by Pacific Northwest Laboratory with the enhanced UT techniques.

60. Scheme of ultrasonic fields of creeping wave probe in test specimen depicting front and back surface creeping waves, direct and indirect longitudinal waves, and direct and indirect shear waves

61. Potential beam propagation paths for multimode approach using creeping wave probe .... 115

62. Examples of time-of-flight diffraction (TOFD) signals $\ldots \ldots \ldots \ldots \ldots \ldots \ldots \ldots \ldots \ldots$

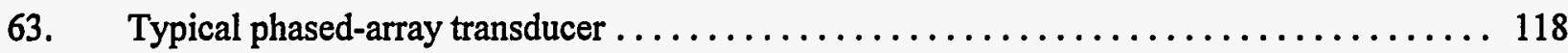

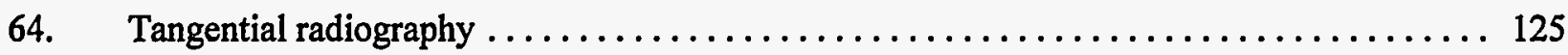

65. Original layout of the feedwater distribution piping inside Siemens/KWU steam generators

66. Modified layout of the feedwater distribution piping inside Siemens/KWU steam generators. The upward bend in the piping prevents flow stratification .

67. Antistratification device for effective mixing of hot and cold coolants in the feedwater nozzle .

68. Local on-line fatigue monitoring of feedwater nozzle-to-pipe weld at

Diablo Canyon Unit 1

69. Local on-line fatigue monitoring results for feedwater nozzle-to-pipe weld at

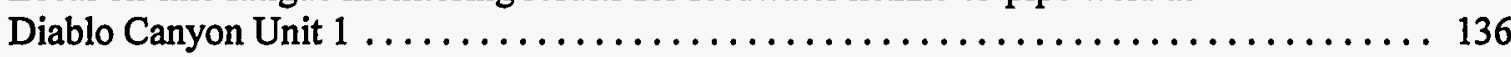

70. Local on-line fatigue monitoring of Beaver Valley Unit 1 feedwater line $\ldots \ldots \ldots \ldots \ldots 138$ 


\section{LIST OF TABLES}

1. Typical materials and fabrication codes for feedwater piping $\ldots \ldots \ldots \ldots \ldots \ldots \ldots \ldots$

2. Typical Diablo Canyon auxiliary feedwater evolutions $\ldots \ldots \ldots \ldots \ldots \ldots \ldots \ldots \ldots$

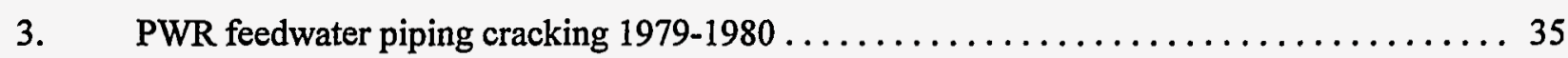

4. PWR feedwater nozzle cracking 1983 to present $\ldots \ldots \ldots \ldots \ldots \ldots \ldots \ldots \ldots \ldots \ldots$

5. Repair/replacement activities 1983 to present $\ldots \ldots \ldots \ldots \ldots \ldots \ldots \ldots \ldots \ldots \ldots$

6. Results of Sequoyah radiographic inspection $\ldots \ldots \ldots \ldots \ldots \ldots \ldots \ldots \ldots \ldots \ldots$

7. PWR plants with pipe wall thinning in the feedwater-condensate systems $\ldots \ldots \ldots \ldots 67$

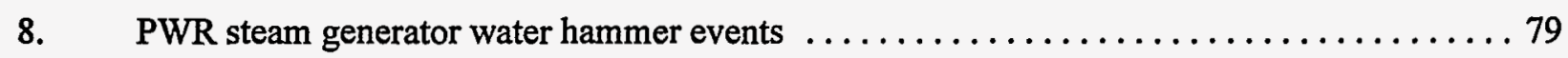




\section{EXECUTIVE SUMMARY}

Pressurized water reactor (PWR) feedwater nozzles, piping, and feedrings have experienced cracking and wall thinning during operation. The cracking was caused by thermal fatigue resulting from flow stratification, and the wall thinning was caused by flow-accelerated corrosion. ${ }^{1}$ In response, the USNRC issued Bulletin 79-13 Cracking in Feedwater System Piping (Revisions 0, 1, 2) in 1979 and Bulletin 87-01 Thinning of Pipe Walls in Nuclear Power Plants in 1987, requesting the nuclear plant operators in the United States (USNRC licensees) inspect susceptible regions of their feedwater systems and take other specific actions. NRC Bulletin 79-13 addressed the fatigue cracking problem, and NRC Bulletin 87-01 addressed the wall-thinning problem. The USNRC licensees performed the inspections requested by the bulletins, made appropriate repairs and replacements, and established corrective programs to manage the cracking and wall thinning issues. USNRC Bulletin 79-13 was closed in 1991.

The objective of this study was to evaluate the effectiveness of industry efforts to manage thermal fatigue, flow-accelerated corrosion, and water hammer damage in feedwater piping. Four specific actions were taken to accomplish the objective: (a) review of field experience to identify trends of operating events, (b) review of related technical literature, (c) visits to three PWR plants where fatigue cracking occurred since the closure of Bulletin 79-13 and a PWR vendor; and (d) solicitation of information from eight other countries.

The report surveys the relevant field experience with PWR feedwater systems, assesses the factors causing the damage, and evaluates the design

1 In the United States, flow-accelerated corrosion is commonly known as erosion-corrosion. We have used the term flow-accelerated corrosion in this report because it describes the degradation process causing the observed wall thinning damage to the PWR feedwater piping. The term flow-accelerated corrosion is now also used in France where the term flow-assisted corrosion was used earlier. modifications, operating procedure changes, augmented inspection programs, and repair and replacement activities that have been carried out because of these problems. The effort focused on a portion of the feedwater system adjacent to the feedwater nozzle where fatigue cracking and wall thinning have been reported in the field. This portion of the feedwater system includes the main and auxiliary feedwater piping adjacent to the feedwater nozzle, and the thermal sleeve, feedring, and J-tubes. The primary areas addressed in this study are as follows: 1) feedwater system design, 2) safety significance of feedwater line ruptures, 3) fatigue cracking experience, 4) flow-accelerated corrosion-induced wall thinning experience, 5) steam generator water hammer damage experience, 6) degradation mechanisms, 7) inservice inspection methods, and 8) mitigation, monitoring, and replacement.

Main and Auxiliary Feedwater System Designs. Each PWR has main and auxiliary feedwater systems, both of which are used to remove heat from the reactor coolant system through the steam generator tubes. The main feedwater system provides the water required to maintain the steam generator secondary side water level during normal operation, whereas the auxiliary feedwater system is used to maintain a heat sink in the steam generators during design basis events such as a reactor trip or a loss of offsite power. The auxiliary feedwater system is also used in most plants, to provide feedwater to the steam generators during plant startup, hot standby, and shutdown.

The main feedwater systems include multiple trains of feedwater piping. The feedwater passes through several feedwater heaters, pumps, common headers, control valves, isolation valves, and check valves, and then enters the steam generator through the main feedwater nozzle. The main feedwater systems are designed to handle large volumes of water [for example, $6.8 \times 10^{6} \mathrm{~kg} / \mathrm{h}\left(15 \times 10^{6} \mathrm{lb} / \mathrm{h}\right)$ at a typical 1,000 MWe unit]. The pressure and temperature of that water increase from 2.0 to 
$3.5 \mathrm{MPa}(300$ to $500 \mathrm{psia})$ and 160 to $204^{\circ} \mathrm{C}(320$ to $400^{\circ} \mathrm{F}$ ) at the discharge from the condensate system to 5.5 to $7.9 \mathrm{MPa}$ (800 to $1150 \mathrm{psia}$ ) and 210 to $238^{\circ} \mathrm{C}\left(410\right.$ to $\left.460^{\circ} \mathrm{F}\right)$ at the steam generator inlet. The auxiliary feedwater source is the condensate storage tank, which is typically at about 38 to $50^{\circ} \mathrm{C}\left(100\right.$ to $\left.120^{\circ} \mathrm{F}\right)$. (This temperature can be lower than $38^{\circ} \mathrm{C}$ for plants with the condensate storage tank located outdoors.) The flow passes through parallel auxiliary feedwater lines, each having an auxiliary feedwater pump, check valves, control valves, and isolation valves.

The thermal fatigue and flow-accelerated corrosion in PWR feedwater systems depend, in part, on the arrangement (design) of the system. The arrangement of the feedwater system associated with recirculating steam generators used in Westinghouse and Combustion EngineeringPWRs and once-through steam generators used in Babcock \& Wilcox PWRs varies. In plants with recirculating steam generators not equipped with preheaters, the cold auxiliary feedwater is typically discharged into the main feedwater line before entering the steam generator. (However, there are some exceptions. In at least one plant with the recirculating steam generators that are not equipped with preheaters, the auxiliary feedwater is discharged directly into the steam generators.) This configuration introduces stratified flow in the main feedwater line and makes it susceptible to fatigue cracking. The main feedwater line is connected to a nozzle located above the tube bundle, which is in turn connected to a feedring and J-tubes; the J-tubes distribute the feedwater in the steam generator.

During plant startup, hot standby, and shutdown, the typical source of feedwater to recirculating steam generators not equipped with preheaters is the auxiliary feedwater; main feedwater can provide the feedwater during these operations if a plant is equipped with electrically driven main feedwater pumps. Generally, this feedwater is cold, but in two Westinghouse PWRs, Wolf Creek and Callaway, a special startup system is provided to supply heated feedwater to the steam generator during startup, hot standby, and shutdown. The main objective of the special startup system is to avoid flow stratification-induced thermal fatigue cracking of the feedwater nozzle and piping.

In plants with preheater-equipped recirculating steam generators, the main feedwater nozzle is located near the tubesheet on the cold-leg side and the cold auxiliary feedwater is discharged directly into the steam generator above the tube bundle. In these plants, the main feedwater is also discharged into the steam generators through the auxiliary feedwater nozzle during startup (when the power is less than about 15 to $20 \%$ of full power), which eliminates the possibility of a condensation-induced water hammer in the preheater. At the 15 to $20 \%$ power level, a very small amount of main feedwater flow is directed through the main feedwater nozzle, which slowly flushes the cold feedwater from the piping downstream of the main feedwater isolation valve and warms up the piping. The main purpose of warming up the piping is to prevent the cold feedwater from collapsing any steam bubbles in the preheater section, which could cause water hammer damage to the preheater. The small amount of feedwater flow used for flushing causes thermal stratification in the main feedwater nozzle and adjacent piping with a top-to-bottom temperature difference, for example, of about $164^{\circ} \mathrm{C}\left(295^{\circ} \mathrm{F}\right)$. The main feedwater nozzles of the preheater-equipped steam generators have been designed for these stratified flow cycles. At full power, about 14 to $18 \%$ of the main feedwater flow is diverted to the auxiliary feedwater nozzle and then into the steam generator. The purpose of splitting the flow during operation, which was not included in the original design, was to reduce fretting damage to the steam generator tubes in the preheater section of some Westinghouse-designed steam generators. However, the auxiliary feedwater piping and the preheater bypass line were not designed for this high flow during operation and, as a result, have experienced significant wall thinning caused by flowaccelerated corrosion.

In plants with once-through steam generators, the main and auxiliary feedwater pass through separate headers located external to the steam generator shell. The feedwater from the headers is introduced into the steam generator through several risers which function like J-tubes in keeping the 
headers full of water. This configuration does not introduce stratified tlows in the main feedwater line.

Safety Significance of Feedwater Line Rupture. Main feedwater line rupture is a design basis accident; its consequences include a potential for core damage. The rupture reduces the ability to remove heat generated by the core from the reactor coolant system. In addition, the resulting loss of feedwater would activate and challenge safety-related systems to cool the reactor core. Thermal fatigue has caused through-wall cracking, but no ruptures of cracked pipes have been reported. However, a cracked feedwater pipe could rupture if it were subjected to seismic or water hammer loads. The USNRC has not accepted the leak-before-break concept for PWR feedwater lines. Flow-accelerated corrosion has caused significant wall-thinning of main feedwater piping and, in a few cases, it has resulted in rupture.

The consequences of a major feedwater line rupture depend on the size and location of the break and the plant operating conditions. If the break occurs between the steam generator and the first check valve on the feedwater piping, secondary coolant from the steam generator can be discharged through the break. The faulted steam generator would rapidly depressurize and as a result, the differential pressure across the faulted steam generator tubes would increase and multiple ruptures of degraded steam generator tubes might occur. If the first check valve is outside the containment and the break is between the containment wall and the check valve, tube leakage would cause release of radioactive products through the break into the environment.

Field Experience Related to Fatigue Cracking. PWR feedwater nozzle cracks were first discovered at the D. C. Cook Unit 2 plant in 1979. As a result, the USNRC issued Bulletin 79-13. Inspections conducted in response to the Bulletin revealed instances of cracking in 18 PWRs, 16 of Westinghouse design and two of Combustion Engineering design. Only the cracks found in the two D. C. Cook Unit 2 feedwater nozzles were through-wall cracks. Typical cracks were trans- granular with a circumferential orientation, initiated at the inside surface, and located at geometric discontinuities in the counterbore region or at nozzle-to-pipe welds. Metallographic studies of the cracked feedwater nozzle samples determined that the cracking was caused by thermal fatigue. Laboratory and field testing indicated that the root cause of cracking was thermal stratification between cold auxiliary feedwater and hot steam generator secondary coolant.

Thermal fatigue cracking of feedwater piping has generally not been reported at plants where the auxiliary feedwater is introduced into the steam generator shell rather than into the main feedwater line; however, in at least one case, fatigue cracking in an auxiliary feedwater nozzle inside radius region has been reported. This cracking occurred because of cold coolant leaking into the gap between the auxiliary feedwater nozzle and its thermal sleeve.

After the inspections conducted in response to NRC Bulletin 79-13 were completed and licensees had performed appropriate repairs and established other corrective actions (approximately from 1979 through 1983), eight more PWRs experienced feedwater nozzle cracking (from 1983 through 1991). Most of these fatigue cracks were similar to those discovered in the 1979 round of inspections, but there were two notable exceptions: leakage at Maine Yankee in 1983, and extensive cracking at Indian Point 2 during the 1989 to 1991 period. The Maine Yankee cracking resulted in a leak when a water hammer caused fracture of an already existing fatigue crack located in the counterbore region of the feedwater line. Fatigue cracking occurred at several locations in the Indian Point 2 steam generators, including the pipe-to-nozzle weld region, the feedwater nozzle bore region under the thermal sleeve, the nozzle inner radius section, and the heat-affected zone of the weld between the feedwater nozzle and the steam generator shell of two steam generators. The cracking in the nozzle bore and blend radius was caused by cold feedwater leaking through a small gap between the nozzle and the thermal sleeve. A feedwater nozzle sealing sleeve was installed in 1991 to eliminate leakage of cold feedwater into 
the gap between the thermal sleeve and nozzle and thus mitigate the nozzle cracking. Similar cracking has been reported in a main feedwater nozzle in a non-U.S. PWR and in an auxiliary feedwater nozzle in a U.S. PWR, as mentioned earlier.

Cracking events in PWR feedwater nozzles have continued to occur since the 1991 closeout of NRC Bulletin 79-13. Leakage through a circumferential crack was found at Sequoyah Unit 1 in March 1992. The crack was located at the feedwater nozzle-to-transition piece weld region at a geometric discontinuity. Metallographic examination revealed that significant cracking was present at five out of eight feedwater nozzles for Units 1 and 2. Most of the major cracks were located on the transition piece side of the weld but two of the major cracks were located on the nozzle side of the weld. During earlier ultrasonic inspections, there were indications recorded at the sites of the cracks, but they were misinterpreted as geometry effects. All the transition pieces were replaced. A subsequent ultrasonic examination at Sequoyah in April 1993 revealed cracking in five of the eight replaced transition pieces; radiographic examination was not able to confirm any of these indications.

The root cause of the cracking at the Sequoyah plants was attributed to thermal fatigue caused by periodic thermal stratification when cold auxiliary feedwater was injected into the main feedwater line and then into the steam generator during hot standby operations. The on-off operation of the auxiliary feedwater flow during the automatic mode of operation produced about three cycles of thermal stratification every hour during hot standby. After the 1993 discovery of cracks, the operating procedures were modified to reduce the time for on-off operation of the auxiliary feedwater flow and to minimize the fluctuations in the flow rate. The other corrective actions included improved inservice inspection procedures, use of enhanced ultrasonic examination techniques, and better training of inservice inspection personnel. In addition, long thermal liners were installed in two feedwater nozzles to protect the nozzle-to-transition piece weld, transition piece, and transition piece-to-elbow weld.
In September 1992, enhanced ultrasonic examination revealed circumferential indications in the counterbore region of the feedwater nozzles at Diablo Canyon Unit 1. Metallographic examinations of samples removed from the counterbore region showed that the ultrasonic examination overestimated the crack size; a crack that was identified by ultrasonic examination as $8.9-\mathrm{mm}$ $(0.35$-in.) deep was found to be only about one tenth that depth. Segregates found in the material near the crack location may have caused the incorrect sizing by the ultrasonic examination. The root cause of the cracking was the same as that identified for the cracking at the Sequoyah plants. The licensee replaced the damaged portion of piping at all four Unit 1 feedwater nozzles, and the auxiliary feedwater cycles are being monitored at both units. Thermal sleeves and feedrings have experienced wall thinning at these two units, as discussed later in this summary.

Ultrasonic examination of the safe ends of the San Onofre Unit 3 feedwater nozzles during 1993 revealed circumferential cracking. It was determined that periodic thermal stratification resulting from the earlier on-off operation of the auxiliary feedwater flow was the root cause of this cracking. In 1985, the licensee modified operation of the auxiliary feedwater flow to minimize the fluctuations in the flow rate. The corrective actions included weld repair of the cracks and use of an augmented inservice inspection program.

Inservice inspections during 1992 and 1993 revealed several unacceptable indications in the feedwater nozzle welds for Salem Unit 1 and the Haddam Neck plant. The indications were removed by grinding. Circumferential cracking at feedwater nozzle welds has been reported in Belgian, Swiss, French and German PWRs.

Field Experience Related to Flow-Accelerated Corrosion. Flow-accelerated corrosion has caused significant wall thinning of the feedwater piping outside the containment at a number of plants, resulting in failures at several of these plants including the failures at the Trojan plant in 1985 and Surry Unit 2 in 1986 . A pressure pulse ultimately caused a rupture of the damaged piping at both Trojan and Surry Unit 2. There was no 
leak or other warning signs indicating incipient failure during either event. Eight workers were burned by flashing feedwater during the Surry accident, four of whom subsequently died. As a result of the Surry accident, the USNRC issued Bulletin 87-01 requesting all utilities with operating nuclear power plants to inspect their high-energy carbon steel piping.

There has also been evidence of damage caused by flow-accelerated corrosion in the safety-related portion of the feedwater piping inside the containment. However, in one instance, it was later found that certain damage was not caused by flow-accelerated corrosion. In 1987, it was initially reported that flow-accelerated corrosion caused significant wall thinning in the horizontal and vertical portions of the feedwater piping inside the containment at the Trojan plant. These portions of the piping were not considered susceptible to flow-accelerated corrosion damage and not included in the inspection program because they were at least seven pipe diameters away from an elbow or any other fittings that could cause turbulence. However, after further analysis the plant operator determined that the damage to these horizontal and vertical portions of the piping was minor and judged not caused by flow-accelerated corrosion but was rather from an initial manufacturing defect. No other utility has reported flow-accelerated corrosion damage in straight piping away from discontinuities. Further inspection of all the high-energy carbon steel piping at Trojan revealed wall thinning at about 30 additional sites, 10 of which were in the safety-related portion of the feedwater system (portion of the system inside the containment), whereas the remaining sites were in the nonsafety-related piping. Failure analysis indicated that flow-accelerated corrosion caused the wall thinning at these additional sites. Failure analysis also indicated that cavitation caused by severe flow conditions at the pump discharge elbows also contributed to the wall thinning at the sites in the nonsafety-related piping.

Flow-accelerated corrosion induced wall thinning has resulted in several feedwater piping ruptures at non-U.S. plants. In 1990, a feedwater pipe at Loviisa Unit 1 ruptured when the plant was operating at full power. The failure location was immediately downstream of a flowmeter flange.
Three reasons have been reported for the Loviisa wall thinning: (1) neutral water chemistry (cold $\mathrm{pH}=7$ ) with low dissolved oxygen, (2) a geometric discontinuity introduced by a flow orifice that produced high flow velocities, and (3) the low-alloy content of the piping material. Nonradioactive water and steam released from the ruptured pipe caused significant damage to nearby cables and small piping, but no important functions were lost.

Generally, the auxiliary feedwater system is in standby during normal operation and, therefore, not susceptible to flow-accelerated corrosion damage. However, for some Westinghouse recirculating steam generators equipped with preheaters, a small portion of the main feedwater flow is diverted through the auxiliary feedwater line during normal operation to reduce fretting damage to the steam generator tubes in the preheater region. This diversion of main feedwater has resulted in significant wall thinning of the auxiliary feedwater piping in some of those Westinghouse plants. If this piping had ruptured, the break would not have been isolable and would have resulted in the steam generator coolant being released outside the containment.

The carbon steel J-tubes and feedrings in the topfeed recirculating steam generators have also experienced significant wall thinning caused by flow-accelerated corrosion. Wall thinning and through-wall penetration of the original carbon steel J-tubes were reported in the late 1970s; and they were replaced with stainless steel or Alloy 600 J-tubes. However, the joint design between the new J-tubes and the feedring introduced geometric discontinuities on the inside surface of the feedring. The resulting turbulence has caused wall thinning of the feedrings at the Diablo Canyon, Surry, and North Anna plants.

Thinning of thermal sleeves has been reported at the Salem Unit 1, Diablo Canyon Units 1 and 2, Prairie Island, Trojan, San Onofre, and Arkansas Nuclear One Unit 2 plants. The damage mechanism was flow-accelerated corrosion. The resulting increased gap between the feedwater nozzle and the thermal sleeve permits increased bypass leakage of the colder feedwater into the hot steam generator coolant present near the nozzle blend 
radius region. Such bypass leakage caused cracking of the nozzle at the Indian Point 2 plant. Monitoring of the nozzle wall temperatures can aid in detecting leakage taking place because of thinning of the thermal sleeves. The repair at the Diablo Canyon plant included installation of a forging that protects the leading edge of the thermal sleeve from flow-accelerated corrosion and protects the nozzle from fatigue damage. Installation of a thermal liner at D. C. Cook, Sequoyah, Beaver Valley and other PWR plants also provide similar protection to the thermal sleeve and the nozzle.

Field Experience Related to Steam Generator Water Hammer. The portions of the main and auxiliary feedwater piping adjacent to main and auxiliary feedwater nozzles have been damaged by steam generator water hammer, which is caused by the collapse of a steam bubble. The sequence of events leading to steam generator water hammer is as follows: (a) when a feedring with bottomdischarge holes is uncovered, the upper portion of the drained feedring and the horizontal length of the adjacent feedwater piping is filled with steam; (b) the auxiliary feedwater flow, which is resumed shortly, enters the horizontal length of the piping and flows under the steam blanket; (c) if the flow rate is high, the resulting turbulence seals off a pocket of steam and forms a slug of cold water; (d) the trapped steam condenses rapidly and, as a result, the slug accelerates into the void; and (e) finally the slug traveling with a high velocity impacts an incoming water column and a pressure pulse is produced. The magnitude of the pressure pulse depends on the slug velocity, which is determined by the distance (horizontal length of the adjacent piping) it has traveled.

About 37 steam generator water hammer events associated with the main and auxiliary feedwater lines of 17 top-feed generators have been reported. Five of these events occurred prior to commercial operation, whereas the others occurred afterward. The data show that the reported occurrences of steam generator water hammer events dramatically decreased after 1979; 28 events occurred during the $1970 \mathrm{~s}$, whereas only 6 occurred during the 1980s. A few steam generator water hammer events associated with the auxiliary feedwater line have also been reported.

Water hammer damage was typically limited to the plant piping support system. However, in a few cases water hammer events have resulted in significant damage to the steam generator internals, including cracked feedrings and expanded thermal sleeves, and cracking and bulging of the main feedwater line. The most damaging event was at Indian Point Unit 2 in 1973, which resulted in a 180-degree circumferential through-wall crack in a 460-mm (18-in.) diameter main feedwater line at the containment penetration. To preclude the recurrence of water hammer events, the feedring was modified to prevent rapid draining by plugging the sparging holes and installing J-tubes on the top of the ring. In addition, the elevation of the long horizontal run of feedwater piping outside the steam generator was lowered about $0.4 \mathrm{~m}$ (16 in.) to prevent the water in this horizontal run from draining into the steam generator whenever the water level in the steam generator dropped below the feedring.

In 1983, a water hammer occurred at the Maine Yankee plant about 15 minutes after the reactor tripped from full power. The water hammer caused rupture of a main feedwater line near the steam generator feedwater nozzle where a preexisting fatigue crack caused by flow stratification was most likely present. Each steam generator feedring was later modified by closing offall 76 bottom-mounted, $25-\mathrm{mm}$ ( 1 -in.) diameter nozzles and installing 28 top-mounted, $90-\mathrm{mm}$ (3.5-in.) diameter elbows. Other preventive actions included removing stress raisers from the pipe inside surface and modifying operations instruction and guidance to reduce the probability of thermal cycling and steam generator water hammer events.

In 1985 , a severe water hammer occurred at San Onofre Unit 1. The events leading to water hammer included loss of power to a main feedwater pump while another one remained energized; failures of multiple check valves that allowed back flow of high-pressure feedwater which ruptured a condenser tube; drainage of the feedwater through 
a ruptured condenser tube; and filling of a long, horizontal portion of the main feedwater line with steam from the steam generator. Water hammer occurred when the auxiliary feedwater flow was established and the isolation valves and flow control valves were closed. As a result, the 254-mm (10-in.) diameter pipe inside the containment was distorted from its original configuration, pipe supports were damaged, and a $2-\mathrm{m}$ (80-in.) long crack was developed. The corrective actions included replacing faulty and damaged check valves, implementing logic which closes the flowcontrol valves upon a loss of main feedwater, and installing redundant check valves in the feed water piping.

The preheat steam generators were not expected to experience water hammer events because the lessons learned from the experience with the water hammer events associated with the top-feed steam generators were incorporated in the preheat steam generator designs. However, a water hammer occurred in the auxiliary feedwater line of a preheat steam generator at KRSKO, a two-loop Westinghouse plant in the former Yugoslavia, during preoperational testing of the auxiliary feedwater line. The water hammer was caused by a steam bubble collapse in an auxiliary feedwater line during a hot functional test in July 1981. The horizontal portion of the line where the water hammer occurred was about $50 \mathrm{ft}$ below the auxiliary feedwater nozzle. Damage was mainly limited to inside the containment: the piping was shifted and bulged about $6 \mathrm{~mm}(0.25$ in.) near the secondary wall (the probable location of water slug impact), and the pipe hangers were damaged. The piping movement was negligible in the intermediate building, but paint on the auxiliary feedwater piping was blistered back to the motordriven auxiliary feedwater pumps. The sequence of events that led to the KRSKO water hammer are not well understood. However, the observed paint damage implies that significant back leakage of steam from the steam generator through the auxiliary feedwater line must have taken place, and several check valves in the auxiliary feedwater lines must have leaked.
Degradation Mechanisms. The characteristics of the damage caused by thermal fatigue are different from those caused by flow-accelerated corrosion. Thermal fatigue cracking generally occurs in a relatively local, safety-related portion of the feedwater piping inside the containment, whereas wall-thinning caused by flow-accelerated corrosion typically occurs, with few exceptions, in the non-safety related balance-of-plant piping outside the containment. A through-wall crack caused by thermal fatigue will generally leak before the component ruptures. However, during an unlikely event resulting in a large overload, a pipe with fatigue cracks might fail catastrophically with no prior leakage. A component damaged by flow-accelerated corrosion loses its strength and can fail under normal operating pressure; a large fitting or pipe might fail catastrophically without warning.

Sites susceptible to thermal fatigue cracking have only been found in those horizontal portions of the piping and nozzles where stratified flows and coolant leakage, respectively, are present; these locations are generally well identified. Sites susceptible to flow-accelerated corrosion are found throughout the feedwater system where the fluid velocities are high and very low-alloy content piping materials are present. These sites are difficult to identify without predictive analysis.

Three different phenomena have caused thermal fatigue damage to PWR feedwater piping: local thermal stratification and thermal striping caused by the flow stratification, and turbulent mixing caused by the bypass leakage through the gap between the thermal sleeve and feedwater nozzle. The most severe fatigue cracking is caused by local thermal stratification. Factors causing high stresses during thermal stratification are the temperature difference between the hot steam generator coolant and the cold auxiliary feedwater, and geometric discontinuities on the inside surface of the feedwater piping. The stress distributions resulting from thermal stratification are complex because of the feedwater nozzle and elbow end constraint effects and because of the geometric discontinuities at the inside surface of the piping. 
The temperature distribution in a pipe wall caused by thermal stratification is plant-specific, because in addition to the differential temperature between the hot and cold stratified fluids and the flow rate, it depends on the piping configuration. Therefore, the results from certain laboratory tests or from some plants may not be directly applicable to another plant.

Thermal striping takes place when high relative velocities between the hot and cold coolants are present and, as a result, the gradient Richardson number is small (for example, less than 0.25 ). The gradient Richardson number is the ratio of the density gradient and horizontal velocity gradient across the thickness of the interface layer between the hot and cold coolants. Stresses produced by thermal striping can initiate cracks on the inside surface but do not cause any significant crack propagation through the thickness, because through-thickness stresses attenuate rapidly. It appears that thermal striping might have contributed to initiation of some fatigue cracks found in the feedwater piping. As discussed above, bypass leakage through the gap between the thermal sleeve and feedwater nozzle has caused fatigue cracking in the nozzle bore, nozzle inside radius, and steam generator shell. It is not known whether such cracking is a common occurrence. Thermal cycling could cause cracking in the auxiliary feedwater piping where it connects to the main feedwater line. However, such cracking has not been reported.

Flow-accelerated corrosion of carbon steel feedwater piping occurs through dissolution of a porous oxide layer of magnetite present on the inside surface of piping and simultaneous formation of a new oxide layer at the metal-oxide interface, a process that reduces the piping wall thickness over time. The kinetics of metal removal by an oxide dissolution process are linear (that is, the corrosion rate is constant in time). The wall thinning rates observed in the field are essentially constant when the influencing factors do not vary. Severely corroded large-diameter piping surfaces produced by single-phase flow-accelerated corrosion are characterized by overlapping horseshoe pits that give an orange peel appearance.
Laboratory test results and data from operating plants have identified several factors that affect flow-accelerated corrosion rates; these factors may be divided in three groups: (a) hydrodynamic variables - fluid velocity, pipe roughness, and flow path geometry defined by piping configuration; (b) metallurgical variables - weight percent of chromium, molybdenum and copper in the steel; and (c)environmental variables - coolant temperature and water chemistry including dissolved oxygen, $\mathrm{pH}$, and the amine used for $\mathrm{pH}$ control.

All PWR plants in the United States use the CHECWORKS code (or its predecessor code CHECMATE) for estimating flow-accelerated corrosion rates. This code has capabilities for estimating parameters (such as local water chemistry and flow rate) that affect corrosion rates, and for predicting corrosion rates and helping to select inspection locations. This computer code was developed by the Electric Power Research Institute and is based on laboratory data from France, England, and Germany, and a set of U.S. plant data. The code has been validated using another set of U.S. plant data, different from the one used to develop the model. The comparison between the predicted results and measurements show that the code predicts flow-accelerated corrosion rates within $\pm 50 \%$. The main sources of uncertainties are associated with the original thickness and thickness profile of the piping components, trace amounts of alloy content in the piping material, actual number of hours of operation, plant chemistry history, and discontinuities on the inside surface of the piping.

Inservice Inspection. Conventional amplitudebased ultrasonic testing (UT) techniques can detect fatigue cracks in ferritic steel piping but have a very poor sizing capability for these cracks. This is illustrated by the round robin UT inspections of thermal fatigue cracks in clad, ferritic steel piping conducted in 1981 by the Pacific Northwest Laboratory. Enhanced UT techniques such as tip diffraction techniques can accurately size the depth of the fatigue cracks. Creeping wave and related mode conversion techniques are also used to detect and qualitatively size fatigue cracks. Radiographic examinations are not adequate for detecting tight thermal fatigue cracks but can detect the cracks 
that are open and filled with corrosion products. Use of an imaging technique such as SyntheticAperture Focusing Technique for Ultrasonic Testing (SAFT-UT) can provide accurate sizing of a crack.

The phased array technique is used for inservice inspection of components such as feedwater nozzles which have a complex geometry, and have very limited access and clearance. Computer modeling can help in determining the best position and angle for a given probe for inspecting a crack of given size and orientation, located in the nozzle inside radius region.

Discrimination of reflectors, such as geometry effects, inclusions, and crack tips, is essential for reliable detection and accurate sizing of fatigue cracks. Use of more than one inspection technique can provide more reliable sizing of the cracks. Implementation of the mandatory Appendix VIII, Performance Demonstrations for Ultrasonic Examination Systems, of ASME Section XI will improve the reliability of detection and the accuracy of sizing of thermal fatigue cracks.

Risk-based criteria for selection of inspection sites are also being developed. Use of these criteria would result in the inspection of locations such as counterbores that are susceptible to thermal fatigue cracking; these locations have often been missed by the current ASME Code selection criteria.

Use of conventional radiographic testing for thickness measurements is limited to smalldiameter piping; inspection of large-diameter piping requires longer exposure times resulting in higher costs and increased personnel exposure. The main advantage of radiography is that it does not require removal of the insulation. Use of filmless radiography with phosphor plates is being evaluated in the field. This technique is expected to dramatically reduce the exposure dose and significantly reduce the inspection time and personnel safety concerns associated with performing radiography within a plant.

Manual UT is the most commonly used inspection method for the detection and trending of changes in the wall thickness because of its accuracy and relatively low cost. A properly conducted UT examination can estimate the pipe wall thickness to within $5 \%$ of the actual value. Industry practice is to overlay a grid on the pipe wall and then spot measure the thickness at each grid location.

The computer code CHECWORKS (or the earlier CHECMATE) discussed above is used by all U.S. PWR utilities for helping to select inservice inspection locations in feedwater piping. Some utilities perform inspections at additional locations based on industry experience or because of the uncertainties associated with several input parameters to the code.

Mitigation, Monitoring, and Replacement. Use of continuous auxiliary feedwater flow rather than intermittent flow significantly reduces the thermal fatigue damage to feedwater piping. Several utilities have implemented continuous flow operation by making physical modifications to the feedwater system and changes in the operating procedures. Also, some plants use heated main feedwater during plant startup and hot standby conditions to mitigate the thermal fatigue damage in the feedwater nozzle region.

Two design changes that reduce the thermal stresses produced by stratified flows include a redesign of the counterbore to reduce the stress raiser, and installation of a thermal liner to protect the counterbore and other susceptible sites from thermal fatigue damage. Several design changes have been made by Framatome and Siemens/KWU to reduce or eliminate the occurrence of flow stratification. These changes include, for example, installation of an antistratification device that breaks down the stratification by mixing the hot and cold coolants, and incorporation of an upward bend in the piping connecting the thermal sleeve to the feedring inside the steam generator. This antisiphon configuration prevents backflow from the steam generator.

Use of a fatigue monitoring system can assist in detecting the presence of thermal stratification and in predicting temperature distributions and flow rates so that the fatigue usage can be estimated more accurately. 
Low-alloy steels such as $11 / 4 \mathrm{Cr}-1 / 2 \mathrm{Mo}$ steel (SA335, Grade P11) and 21/4Cr-1Mo steel (SA-335, Grade P22), austenitic stainless steel, and Alloy 600 are used to replace the existing carbon steel piping when excessive wall thinning caused by flow-accelerated corrosion is found. The presence of $0.1 \mathrm{wt} \%$ or more chromium provides protection against flow-accelerated corrosion.

The optimum $\mathrm{pH}$ in the PWR secondary steam/ water system is generally achieved by the addition of reagents such as ammonia, morpholine, and ethanolamine in the demineralized water. These amines are volatile and, therefore, maintain a slightly alkaline $\mathrm{pH}$ in both the single-phase and two-phase regimes of the secondary system, which reduces the flow-accelerated corrosion in the entire system. The selection of $\mathrm{pH}$ is mainly a compromise between the acceptable corrosion of piping and components made of carbon steel and copper alloys. Ammonia can be used for $\mathrm{pH}$ control in feedwater systems with no copper alloy materials and no condensate polishers; however, the cold pH should be increased, at least up to 9.7 , to avoid flow-accelerated corrosion damage. Morpholine is widely used in the feedwater systems with copper alloy materials in the water heaters and condensers to maintain the cold $\mathrm{pH}$ in the range of 8.8 to 9.2, provided there are no condensate polishers. Another amine, ethanolamine, may be used instead of morpholine when condensate polishers are present. The nuclear industry experience indicates that transport of corrosion products with ethanolamine is lower than that with ammonia, and even lower than that with morpholine. A large number of U.S. PWRs are currently switching or contemplating switching to ethanolamine.

Use of optimum water chemistry reduces wall thinning rates but does not eliminate them; some research results show that the maximum rates are still about 0.1 to $0.2 \mathrm{~mm} / \mathrm{yr}(0.004$ to $0.008 \mathrm{in} . / \mathrm{yr})$, even when the water chemistry is optimum. Therefore, comprehensive, exhaustive, and conservative analyses of the feedwater system need to be performed to identify all sites susceptible to flow accelerated corrosion and these sites need to be inspected periodically for wall thickness loss.
Several design modifications and operational procedure changes made to the feedwater systems in the 1970s and 1980s appear to be adequate for preventing water hammer in the top-feed steam generators; no water hammer events have been reported recently. The holes in the bottomdischarge feedring were plugged, and J-tubes or discharge elbows were installed on the top of the feedring. This modification prevents rapid draining of the feedring when it is uncovered. In addition, the length of the horizontal run of feedwater piping was reduced to less than $2.44 \mathrm{~m}$ $(8 \mathrm{ft})$ so that the magnitude of the pressure pulse resulting from the water hammer is sufficiently reduced. In some new steam generators, the thermal sleeve is welded to the feedwater pipe to stop the drainage through the gap between the sleeve and the nozzle in the event the feedring is uncovered. The operating procedure change required prompt resumption of feedwater flow into the steam generator to minimize the amount of steam that enters the feedring and piping. However, the feedwater flow rate must be limited to about $570 \mathrm{l} / \mathrm{min}$ (150 gpm) so that a slug of cold water does not form.

Findings. Our assessment of field experience related to PWR feedwater nozzle cracking is that the USNRC licensees have apparently taken sufficient actions to minimize the feedwater nozzle cracking caused by thermal fatigue. As a result of the examinations conducted in response to Bulletin 79-13, feedwater nozzle fatigue cracking was detected in 18 PWRs during 1979 to 1983 . Then, there was about one fatigue cracking event per year from 1983 to the bulletin closure in 1991. The frequency of feedwater nozzle cracking events increased to six per year during 1992 and 1993. But since then through 1996, we have not identified any additional feedwater nozzle cracking event.

Our assessment of field experience related to flowaccelerated corrosion damage shows four components in the portion of the feedwater piping within the scope of this report that have experienced significant wall thinning: carbon steel J-tubes, feedrings, and thermal sleeves in the top-feed 
steam generators, and auxiliary feedwater lines in the preheat steam generators. The USNRC licensees have taken sufficient action to minimize the wall thinning in J-tubes and auxiliary feedwater lines. However, we did not find specific industry actions to minimize the wall thinning in feedrings and thermal sleeves, but we found visual inspection being performed and repair when needed.

Our assessment of field experience related to steam generator water hammer damage indicates that the USNRC licensees have taken sufficient action to minimize water hammer in both top-feed and preheat steam generators. However, we have not evaluated the industry efforts to minimize the multiple check valve failures that have played a major role in several steam generator water hammer events.

The major technical findings are as follows.

- The characteristics of the damage caused by thermal fatigue are different than those caused by flow-accelerated corrosion. Thermal fatigue cracking generally occurs in a relatively local, safety-related portion of the feedwater piping inside the containment, whereas wall-thinning caused by flowaccelerated corrosion typically occurs, with few exceptions, in the non-safety related balance-of-plant piping outside the containment.

- A through-wall crack caused by thermal fatigue will generally leak long before the component ruptures. However, during an unlikely event of a large overload, a pipe with fatigue cracks might fail catastrophically without any prior leakage. A component damaged by flow- accelerated corrosion loses its strength and can fail under normal operating pressure; a large fitting or piping might fail catastrophically without any warning.

- Sites susceptible to thermal fatigue cracking are found in those portions of the feedwater piping and nozzles where stratified flows and coolant leakage, respectively, are present; these locations are generally well identified. Sites susceptible to flow-accelerated corrosion are found throughout the feedwater system and are difficult to identify without predictive analysis because several factors are involved.

- The factors causing thermal fatigue and flowaccelerated corrosion damage are well understood. Advanced ultrasonic examination techniques can be used to reliably characterize thermal fatigue cracks. Cost-effective radiographic techniques for estimating wall thickness are being developed as a means to assess flow-accelerated corrosion damage.

- Several effective techniques have been developed for monitoring, mitigating, and repairing the damage caused by thermal fatigue and flow-accelerated corrosion.

The above findings indicate that appropriate analysis, inspection, monitoring, mitigation, and replacement techniques have been developed for managing thermal fatigue and flow-accelerated corrosion damage to feedwater nozzles, piping, and feedrings. Adequate training and appropriate applications of these techniques will ensure effective management of the damage. Several PWR plant operators have been proactive in managing this damage. 


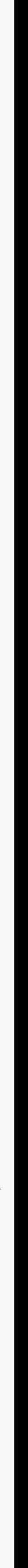




\section{ACRONYMS}

\begin{tabular}{|c|c|}
\hline AFW & auxiliary feedwater \\
\hline ANSI & American National Standards Institute \\
\hline ASME & American Society of Mechanical Engineers \\
\hline ASTM & American Society for Testing and Materials \\
\hline$B \& W$ & Babcock and Wilcox \\
\hline BWR & boiling water reactor \\
\hline CANDU & Canadian Deuterium Uranium \\
\hline CERL & Central Electric Research Laboratories \\
\hline CHECWORKS & Chexal-Horowitz Engineering-Corrosion WORKStation \\
\hline CT & computer tomography \\
\hline DAC & distance amplitude correction \\
\hline EPRI & Electric Power Research Institute \\
\hline FATS & Focused Array Transducer System \\
\hline HPSI & high pressure safety injection \\
\hline IGSCC & intergranular stress corrosion cracking \\
\hline ISI & inservice inspection \\
\hline JAPEIC & Japan Power Engineering and Inspection Corporation \\
\hline LVDT & linear variable differential transformer \\
\hline MFIV & main feedwater isolation valve \\
\hline MINAC & miniature linear accelerator \\
\hline $\mathrm{MT}$ & magnetic particle testing \\
\hline NDE & non-destructive examination \\
\hline NPS & nominal pipe size \\
\hline NSP & Northern States Power \\
\hline NSSS & nuclear steam supply system \\
\hline OD & outside diameter \\
\hline OECD & Organization for Economic Cooperation and Development \\
\hline PARIS & Portable Automated Remote Inspection System \\
\hline PATT & pulse arrival time techniques \\
\hline PISC & Program for Inspection of Steel Components \\
\hline PNL & Pacific Northwest Laboratory \\
\hline PSI & preservice inspection \\
\hline PWR & pressurized water reactor \\
\hline RCS & reactor coolant system \\
\hline RHR & residual heat removal \\
\hline RMS & root mean square \\
\hline RT & radiographic testing \\
\hline RTD & Rontgen Technische Dienst \\
\hline RTR & real time radiography \\
\hline SAFT-UT & Synthetic Aperture Focusing Technique for Ultrasonic Testing \\
\hline SNUPPS & Standard Nuclear Unit Power Plant System \\
\hline SPOT & Satellite Pulse Observation Technique \\
\hline TEMP & Transient ElectroMagnetic Probe \\
\hline TOFD & time of flight diffraction \\
\hline USAS & United States of America Standard \\
\hline USNRC & United States Nuclear Regulatory Commission \\
\hline UT & ultrasonic testing \\
\hline
\end{tabular}




\section{ACKNOWLEDGMENTS}

We acknowledge the significant role played by E. J. Brown of the United States Nuclear Regulatory Commission (USNRC) in providing technical guidance and several reviews of the report. We also acknowledge E. A. Trager and J. R. Boardman of USNRC in providing programmatic guidance.

We sincerely thank the following technical experts for providing information during the plant visits and reviewing the report: G. Wade, K. House, W. Goins, M. Lee, T. Greer, and W. C. Ludwig of Tennessee Valley Authority; the late E. Regala and S. Shaw of Southern California Edition; and P. Hirschberg, H. J. Thailer, D. Gonzalez, L. F. Goyette, and K. J. Dalal of Pacific Gas and Electric. The authors also thank W. Cullen, J. Houtman, W. Bamford, D. Kurek, D. Popovich, A. Thurman, and C. Hu of Westinghouse Electric for providing technical information about the fatigue cracking in feedwater nozzles and reviewing the report.

We sincerely thank R. E. Johnson of USNRC and P. E. MacDonald of Lockheed Martin Idaho Technologies Company (LMITCO) for an in-depth, critical review of the entire report. We also thank L. F. Goyette of Pacific Gas and Electric for several discussions on flow-accelerated corrosion damage to feedwater piping.

We sincerely acknowledge the following technical experts for reviewing several sections of the report: D. Munson, R. Carter, S. R. Gosselin and their coworkers at the Electric Power Research Institute; K. Parczewski, M. Hartzman and D. Terao of USNRC; and J. A. Seydel, M. T. Anderson, M. B. Sattison, J. F. Cook and W. J. Galyean of LMITCO. We would like to thank D. A. Prawdzik, W. F. Steinke, and J. B. Hudson also of LMITCO for providing description of several special features of the feedwater system operation. The authors would like to acknowledge the efforts of S. T. Khericha in preparing parts of Section 2 and 5.

We sincerely acknowledge J. H. Bryce for providing the programmatic guidance and performing an editorial review of the complete report. Our thanks to the Idaho National Engineering Laboratory technical library staff for their prompt and courteous response to our numerous requests for technical reports and papers. Our special thanks to L. Brown for performing many searches for the documents in the Nuclear Documents System. We also thank A. J. Haroldsen and C. E. White for preparing the figures and D. R. Pack for providing editorial guidance. Finally, we sincerely acknowledge A. M. Grimes for her countless efforts and patience in promptly incorporating many of our changes in the report and preparing the final manuscript of the report. 


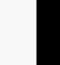




\section{Review of Industry Efforts to Manage Pressurized Water Reactor Feedwater Nozzle, Piping, and Feedring Cracking and Wall Thinning}

\section{INTRODUCTION}

Several pressurized water reactor (PWR) feedwater nozzles, piping, and feedrings have experienced cracking and wall thinning during operation. The cracking of feedwater nozzles and piping was caused by thermal fatigue resulting from the use of cold auxiliary feedwater during certain plant operations such as startup and hot standby and from feedwater leakage bypassing the thermal sleeve. The specific thermal fatigue mechanisms causing cracking include thermal stratification, thermal striping, and turbulent mixing. The wall thinning of carbon steel piping and feedrings was caused by a corrosion process resulting from the use of deoxygenated feedwater and high local fluid velocities. The specific corrosion mechanism causing wall thinning is flow-accelerated corrosion. ${ }^{1}$

Main feedwater line rupture is a design basis accident. The rupture reduces the ability to remove heat generated by the core from the reactor coolant system. In addition, the resulting loss of feedwater would activate and challenge safetyrelated systems to cool the reactor core. Thermal fatigue has caused through-wall cracking of feedwater piping at a few PWRs but has not caused rupture of feedwater piping. However, a cracked feedwater pipe could rupture if it were subjected to seismic or water hammer loads. Flow-accelerated corrosion has caused significant wall-thinning of main feedwater piping and feedrings, and, in several instances, it has resulted in rupture. Steam

1 In the United States, flow-accelerated corrosion is commonly referred to as erosion-corrosion. The term flowaccelerated corrosion is now also used in France where the term flow-assisted corrosion was used earlier. generator water hammer events have also caused a few.ruptures of feedwater piping and feedrings.

In response to the cracking and wall thinning events, the United States Nuclear Regulatory Commission (USNRC) issued Bulletins $79-13^{2}$ and $87-01^{3}$ that requested U.S. nuclear power plant operators to perform inspections of susceptible regions and take several other specific actions. The USNRC licensees performed the inspections identified in the Bulletins, made appropriate repairs and replacements, and established corrective programs to manage the cracking and wall thinning issues. The Bulletin addressing the cracking problem was issued in 1979 and closed in 1991. The Bulletin addressing the wall-thinning problem was issued in 1987.

The main objective of this report is to review operating experience and evaluate the effectiveness of the licensees' programs for managing thermal fatigue, flow-accelerated corrosion, and water hammer damage in the feedwater piping. This includes an evaluation of design modifications, operating procedure changes, augmented inspection programs, and repair and replacement activities.

Four specific actions were taken to accomplish the objective: (a) review of field experience to identify trends of operating events, (b) review of related technical literature, (c) visits to PWR plants and to

2 USNRC Bulletin 79-13: Cracking in Feedwater System Piping, Revisions 0, 1, 2.

3 USNRC Bulletin 87-01: Thinning of Pipe Walls in Nuclear Power Plants. 
a PWR vendor, and (d) solicitation of information from non-US utilities.

The literature reviewed included Information Notices and Bulletins issued by the USNRC, documents submitted to the USNRC by PWR utilities and vendors, reports published by the USNRC and the Electric Power Research Institute (EPRI), journal articles, papers presented at technical meetings, and conference proceedings. We visited three PWR plants where fatigue cracking occurred after the Bulletin 79-13 closed in 1991: Diablo Canyon, San Onofre, and Sequoyah. We visited Westinghouse Electric Corporation, which was involved from the beginning in resolving the feedwater nozzle cracking problem. PWR utilities from eight other countries responded to our request to the Organization for Economic Cooperation and Development (OECD) for plant-specific information about managing feedwater line cracking and wall thinning. Questions requesting the information are listed in the Appendix.
The main focus of the report is on the portion of the feedwater system adjacent to the feedwater nozzle where fatigue cracking and wall thinning have been reported in the field. Figure 1 is a sketch of this portion of the feedwater system, which includes the main and auxiliary feedwater piping adjacent to the feedwater nozzle, and the thermal sleeve, feedring, and J-tubes.

The overall design of the main and auxiliary feedwater systems for top-feed steam generators is described in Section 2. The relevant differences in the feedwater system layout for the steam generators with preheaters are also identified. The design, materials, and fabrication of the feedwater nozzles, piping, and feedring are described in Section 3. The operating transients and environment for feedwater piping and nozzles are described in Section 4. The safety significance of main feedwater line break events is evaluated in Section 5. The field experience related to thermal fatigue cracking, wall thinning caused by flow-

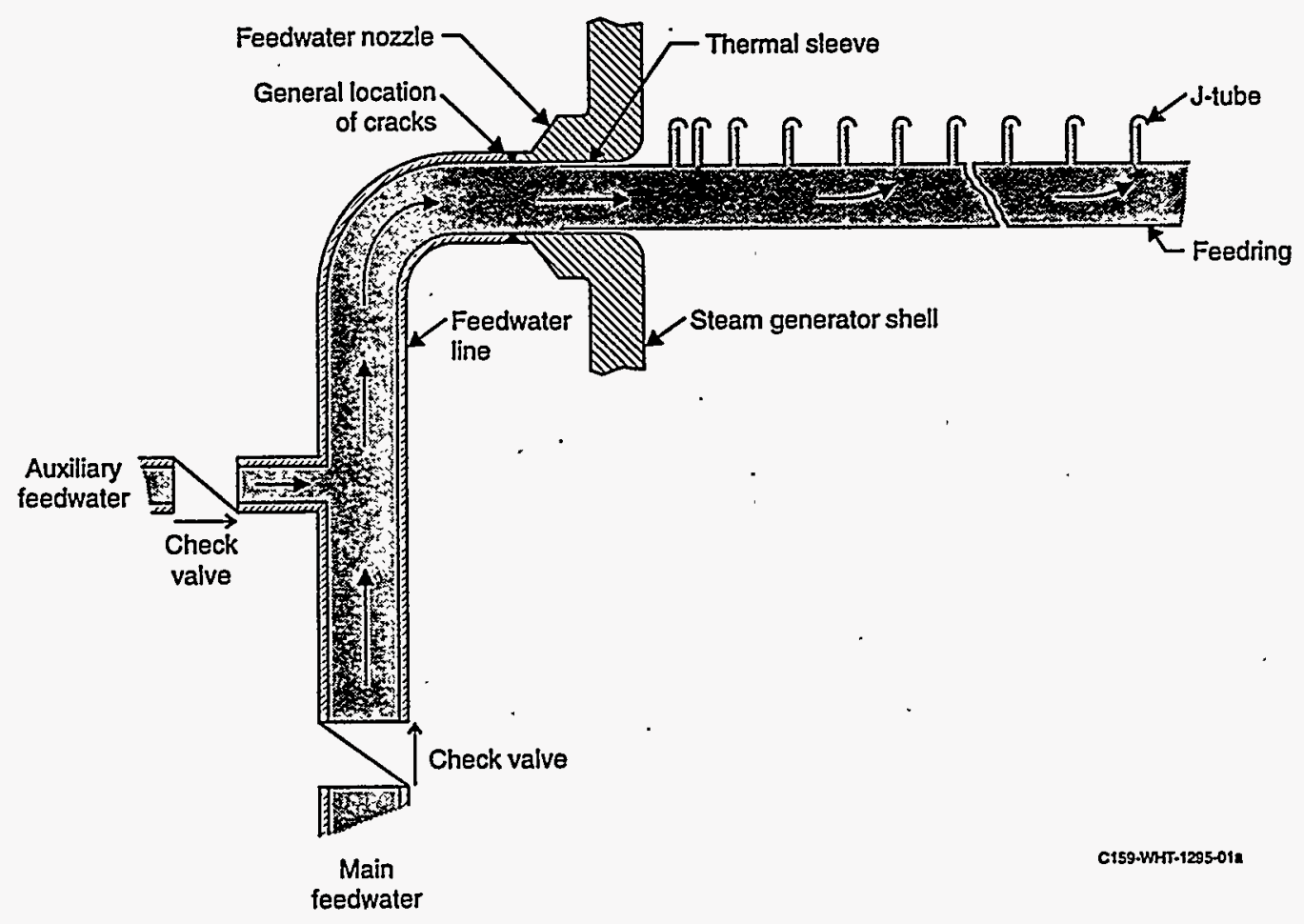

Figure 1. Sketch of a portion of the PWR feedwater system and its components evaluated in the report. 
accelerated corrosion, and steam generator water hammer damage is summarized in Section 6. This section presents root cause analyses for damage experienced in the field. It summarizes the inspections performed by the licensees to characterize the damage, and the actions taken to mitigate the damage. The information obtained from non-US utilities is also summarized in this section.

The remaining sections of the report include discussion on how the interactions between design, materials, stresses, and environment cause fatigue cracking and wall thinning of the feedwater piping and the other components shown in Figure 1, and how the damage can be characterized and mitigated. The qualitative and quantitative effects of piping materials, design and layout; coolant chemistries and temperatures; and flow velocities on thermal fatigue cracking and on wall thinning caused by flow-accelerated corrosion are discussed in Section 7. Different inspection techniques developed to characterize fatigue cracks and wallthinning are evaluated in Section 8. The related field experience in the United States and other countries is also summarized in this section. The current inservice inspection requirements are also summarized. Several techniques to mitigate and monitor thermal fatigue, flow-accelerated corrosion, and water hammer damage to feedwater piping, feedwater nozzles, thermal sleeves, feedrings, and J-tubes are described in Section 9. Finally, the specific findings related to the effectiveness of the industry efforts for managing thermal fatigue cracking and wall thinning of PWR feedwater system components are presented in Section 10. 


\section{MAIN AND AUXILIARY FEEDWATER SYSTEM DESCRIPTIONS}

Both main and auxiliary feedwater systems are used to remove heat from the reactor coolant system. The main feedwater system provides water required to maintain steam generator water level during normal operation, after startup and before shutdown. The auxiliary (or emergency) feedwater system is used to maintain a heat sink in the steam generators during design basis events such as loss of main feedwater, reactor trip, and loss of offsite power. In most plants, the auxiliary feedwater system is also used to provide a source of feedwater to the steam generators during plant startup, hot standby, and shutdown. Thus the auxiliary feedwater system is used when the main feedwater system is not available and the pressure in the reactor coolant system is too high to permit heat removal by the residual heat removal system.

\subsection{Main Feedwater System}

PWR main feedwater systems generally include multiple trains of feedwater piping (usually with a few large headers at selected points) to handle the large volume of feedwater, for example, $6.8 \times 10^{6}$ $\mathrm{kg} / \mathrm{h}\left(15 \times 10^{6} \mathrm{lb} / \mathrm{h}\right)$ for a typical $1100-\mathrm{MWe}$ unit. A multiple-train design also provides redundancy in the feedwater system that is beneficial for safety reasons. The main feedwater system receives water from the condenser hot well and supplies it via a sequence of heaters and pumps at a much higher temperature and pressure to the steam generators. (The feedwater is pressurized by the condensate and feed pumps, and in some plants, feedwater booster pumps). The downstream piping terminates at the steam generator feedwater nozzle.

Figure 2 presents a simplified schematic of a typical main feedwater system for a Westinghouse 4-loop plant with top-feed steam generators (steam generators without preheaters). This flow.diagram begins downstream of the low-pressure feedwater heaters (not shown), at the booster pumps. The flow proceeds through the sets of intermediate feedwater heaters to the two main feedwater pumps; in some plants, both main feedwater pumps are turbine-driven, whereas in other plants both pumps are electrically driven. Some plants have three rather than two main feedwater pumps and both types of pumps. The feedwater pumps discharge pressurized feedwater into a common header, which then passes through three parallel high-pressure heaters into another common header, and then branches into four lines to feed the steam generators through the main feedwater nozzle. The nozzle is located above the tube bundle in a recirculating steam generator without a preheater, as shown in Figure 3, whereas in a recirculating steam generator with a preheater it is located near the tube sheet on the cold-leg side of the steam generator, as shown in Figure 4. In a steam generator without a preheater, the feedwater enters through the feedwater nozzle to a feedring and then to J-tubes, which distribute the feedwater in the steam generator, as shown in Figure 5. The Jtubes direct the water downward into the steam generator downcomer formed by the shell and the baffle around the steam generator tubes. Each feedwater line for the Westinghouse steam generators has its own feed control valve, isolation valve, and check valve.

Generally, in a recirculating steam generator without a preheater, an auxiliary feedwater system discharge line connects with each main feedwater line before it enters the steam generator. In some feedwater systems this connection with the auxiliary feedwater line is inside the primary containment, whereas in others it is outside the containment. However, there are exceptions; for example, in the Palisades plant, the auxiliary feedwater line connects directly to the steam generator, which is not equipped with a preheater. Also, in a steam generator equipped with a preheater, the auxiliary feedwater line connects directly to the steam generator above the tube bundle. Westinghouse 2-, 3-, and 4-loop plants and Combustion Engineering plants have similar feedwater system design configurations. 


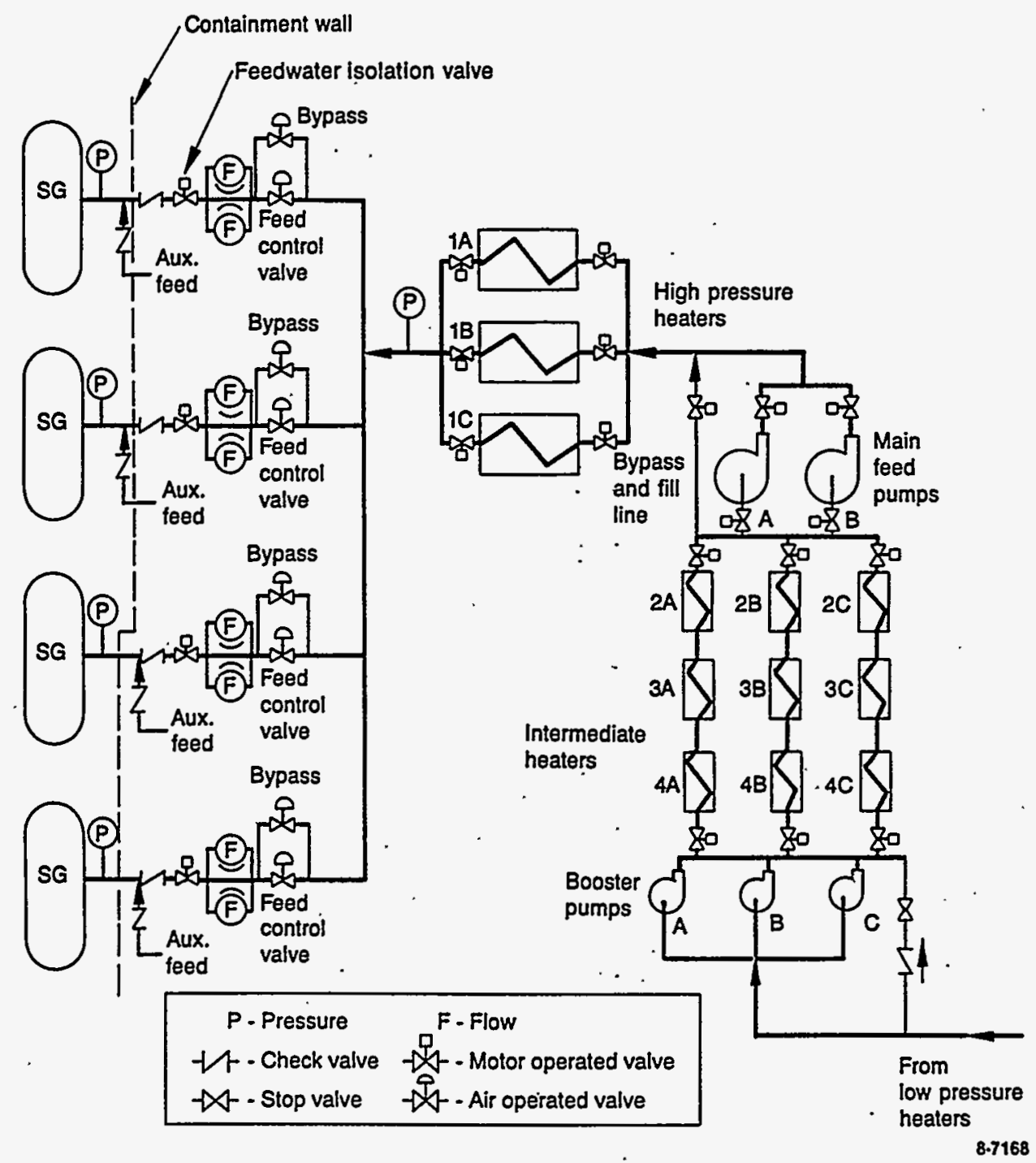

Figure 2. Schematic of a typical main feedwater system for a Westinghouse 4-loop plant with top-feed steam generators (USNRC Inspection and Enforcement Training Center). 


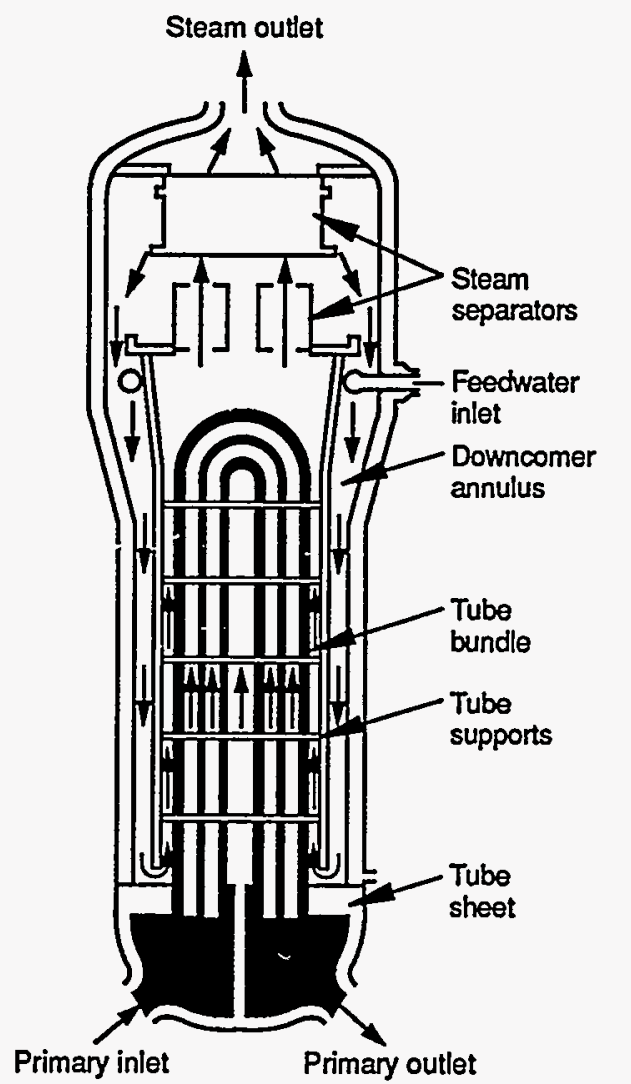

Recirculating steam generator $\quad$ N93 0022 rev dp

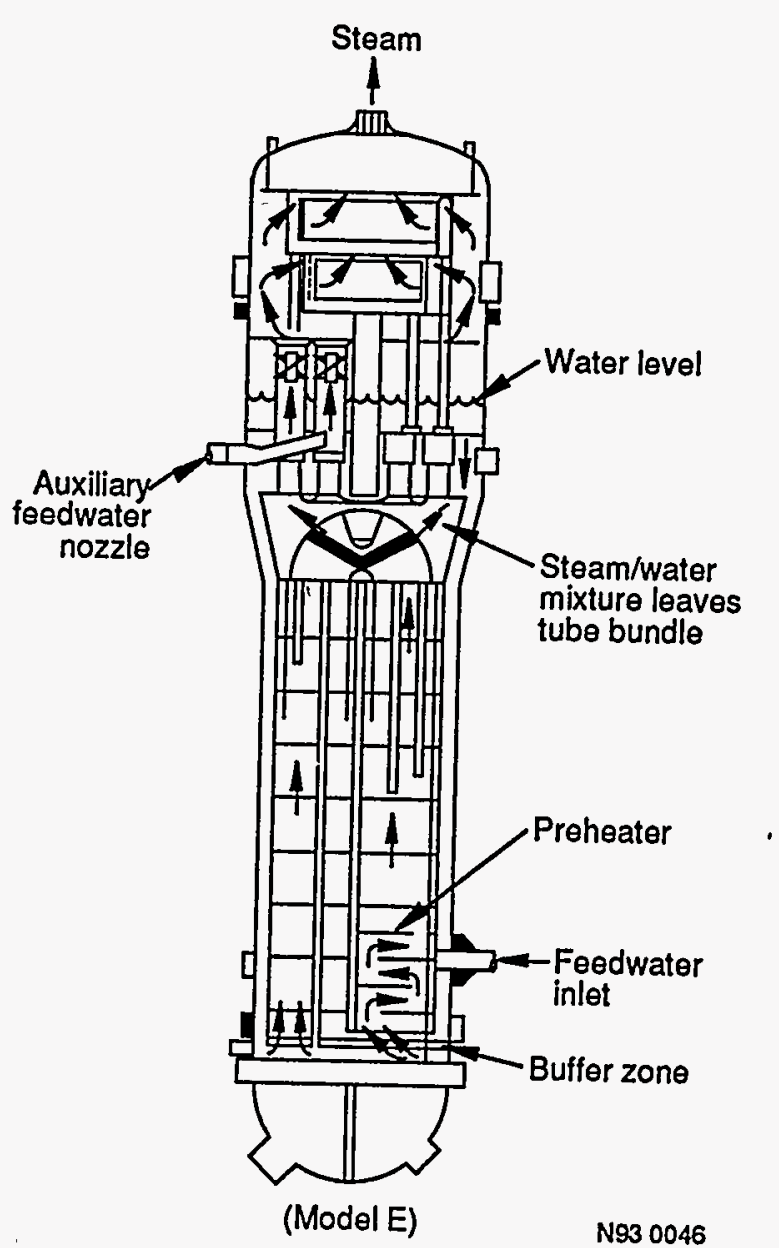

Figure 4. Sketch of a recirculating steam generator with a preheater. The main feedwater nozzle is located near the tubesheet elevation. 


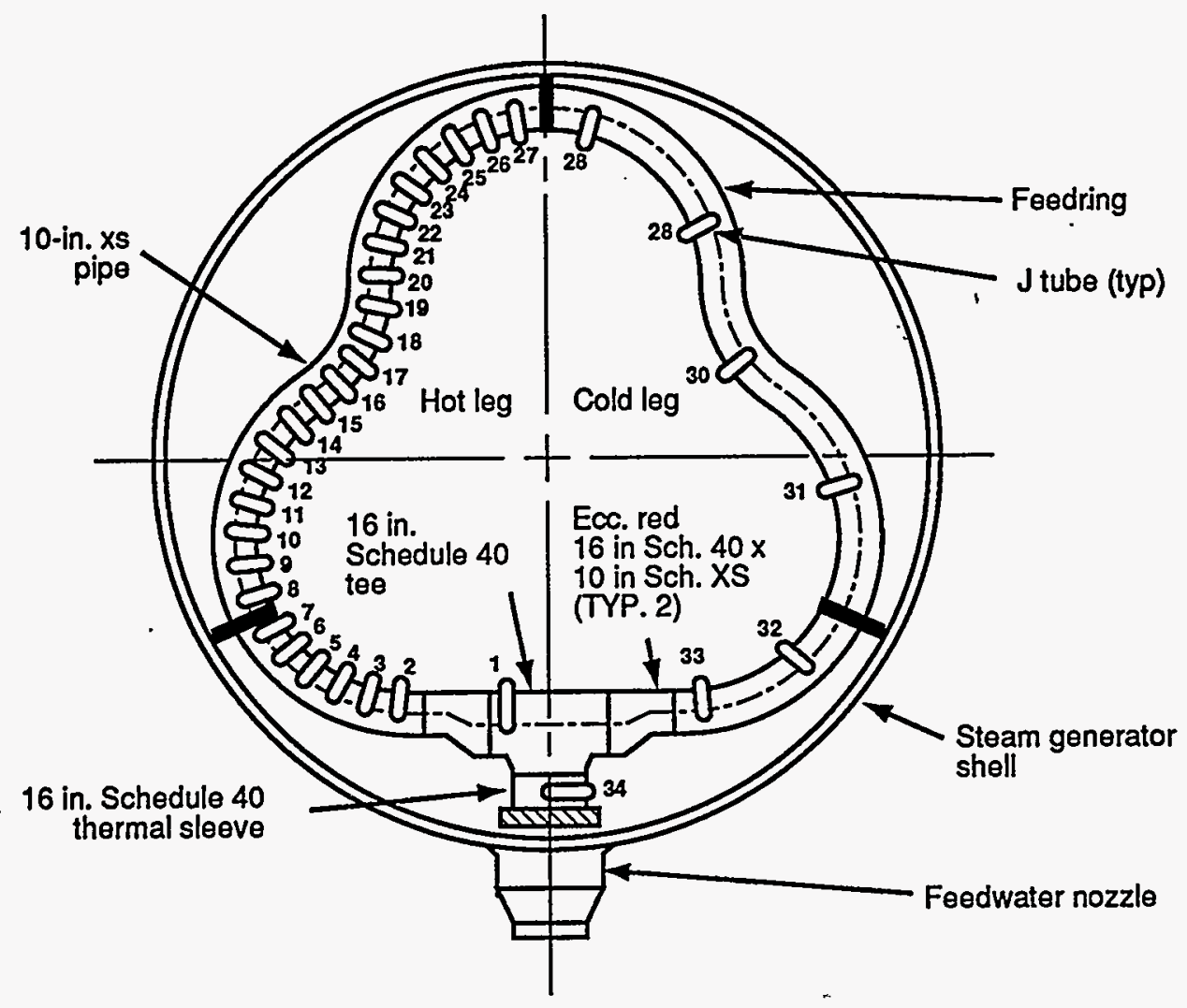

(a) Feedring

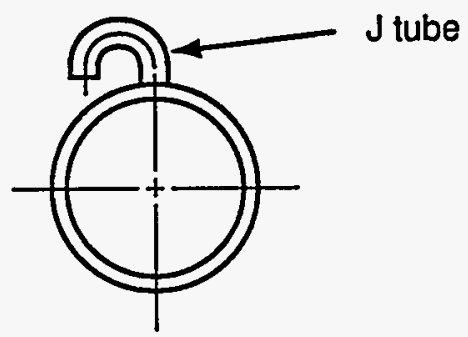

M95 0212

(b) Typical feedring cross section showing $\mathrm{J}$ tube arrangement

Figure 5. Top view of Diablo Canyon feedring (Thailer, Dalal, and Goyette 1995). Copyright American Society of Mechanical Engineers; reprinted with permission. 
A simplified schematic of a Babcock \& Wilcox (B\&W) main feedwater system is shown in Figure 6. There are two parallel trains of feedwater. In each, the flow passes through low-pressure heaters, the main feedwater pump, and high-pressure heaters, finally discharging into a common header. The flow then branches into separate lines feeding the feedwater header of each of the two once-through steam generators. Then the feedwater enters each steam generator through several risers spaced along the feedwater header, as shown in Figure 7. Each feedwater line has its own feed control valve,'main stop valve, and check valve.

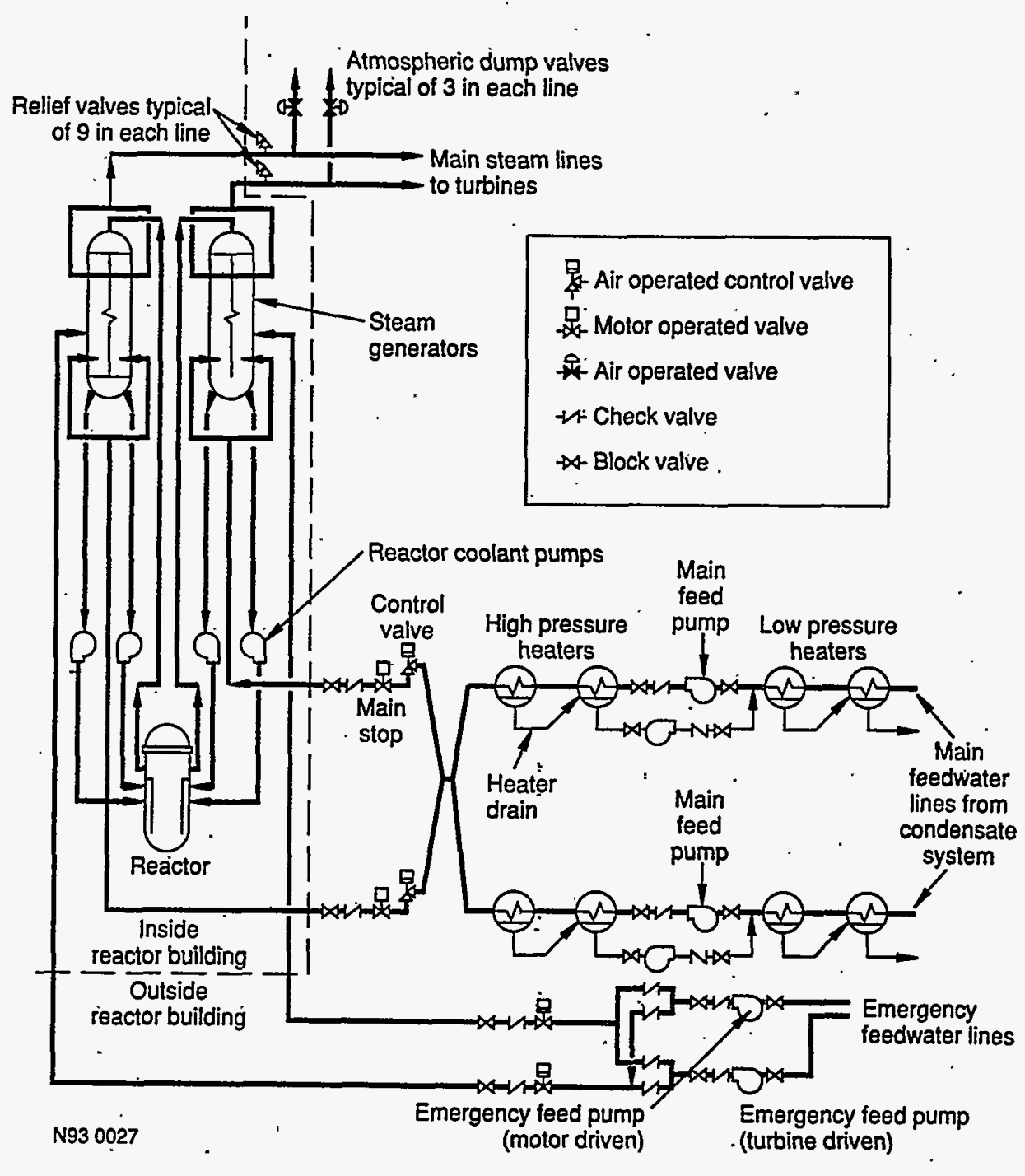

Figure 6. Schematic of a typical main feedwater system for a Babcock \& Wilcox plant. 


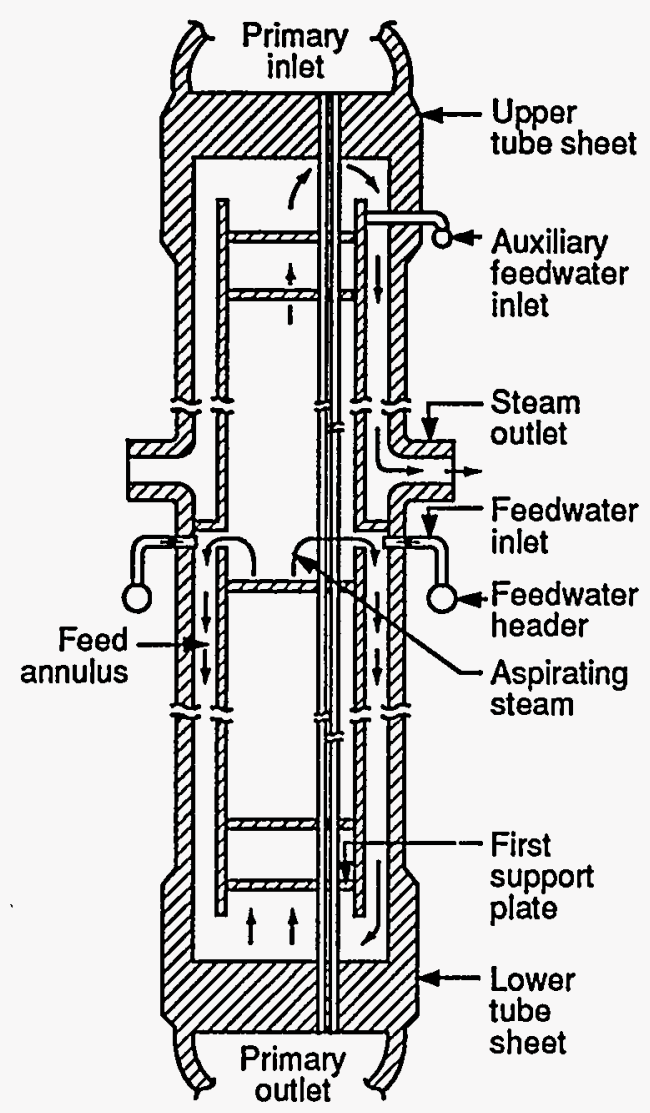

(a) Once-through

M95 0334

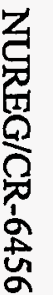

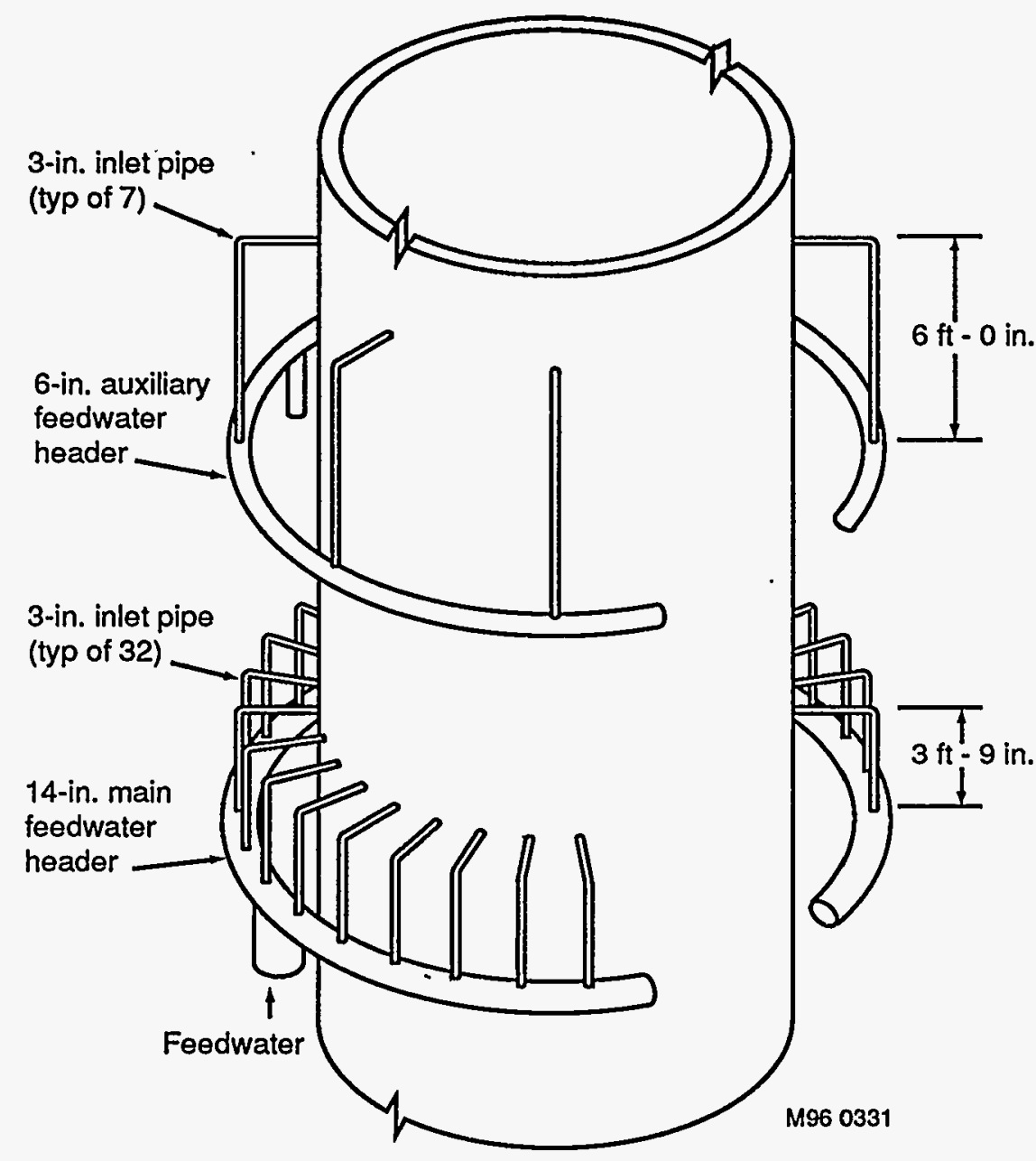

(b) Sketch of feedrings

Figure 7. Cross-section of a Babcock \& Wilcox once-through steam generator with external header (Han and Anderson 1982). 
Main feedwater flow generally initiates at the end of hot standby (Mode 3 operation, see Section 4) and the beginning of plant startup (Mode 2 operation). Initially at low power, the main feedwater pumps are driven with steam from the main steam system; later on at higher power, the pumps switch to the steam from the main turbine. In some plants with electrically driven main feedwater pumps, the main feedwater system, instead of auxiliary feedwater system, can be used to provide feedwater to the steam generators during plant startup, hot standby, and shutdown.

The main turbine extraction steam supplies the heat to the main feedwater heaters; initially the amount of heat supplied is small and it increases as the power increases. So initially the main feedwater is cold when it is started and there is a large temperature difference between the main feedwater and the secondary coolant in the steam generator; this temperature difference decreases as the power increases. For example, Consumers Power (1979) reported that the initial temperature of the main feedwater at the Palisades plant was about $127^{\circ} \mathrm{C}\left(260^{\circ} \mathrm{F}\right)$ at less than $1 \%$ power; then the temperature was raised to about $160^{\circ} \mathrm{C}$ $\left(320^{\circ} \mathrm{F}\right)$ at $20 \%$ power, and to about $215^{\circ} \mathrm{C}$ $\left(420^{\circ} \mathrm{F}\right)$ at full power. The temperature differences between the main feedwater and the secondary coolant in the steam generator were about $130^{\circ} \mathrm{C}\left(250^{\circ} \mathrm{F}\right), 105^{\circ} \mathrm{C}\left(200^{\circ} \mathrm{F}\right)$, and $53^{\circ} \mathrm{C}$ $\left(100^{\circ} \mathrm{F}\right)$ at $1 \%, 20 \%$, and $100 \%$ power respectively. During low power operation, the main feedwater flow rate is manually controlled and there are fluctuations in the flow rate. Therefore, if the flow rate is sufficiently low, stratified-flow cycles could take place during low power operation.

Some PWR units have steam generator feedwater pressures much higher than the coolant saturation pressure, whereas other units have feedwater pressure at the suction of the feedwater pump close to the saturation pressure (Jonas 1988). The operating pressure and temperature at the inlet to the main feed pumps at $100 \%$ load vary from 2.0 to $3.5 \mathrm{MPa}$ (300 to $500 \mathrm{psia}$ ) and 160 to $204^{\circ} \mathrm{C}$ $\left(320\right.$ to $\left.400^{\circ} \mathrm{F}\right)$, respectively; while at the outlet, they vary from 5.9 to $8.3 \mathrm{MPa}$ (850 to 1200 psia) and 160 to $204^{\circ} \mathrm{C}\left(320\right.$ to $\left.400^{\circ} \mathrm{F}\right)$, respectively. The typical feedwater pressure and temperature at the steam generator inlet vary from 5.5 to $7.9 \mathrm{MPa}$ ( 800 to 1150 psia) and 210 to $238^{\circ} \mathrm{C}$ (410 to $460^{\circ} \mathrm{F}$ ). The typical bulk flow velocities at $100 \%$ load range from 3 to $7.6 \mathrm{~m} / \mathrm{s}$ (10 to $25 \mathrm{ft} / \mathrm{s}$ ). However, local flow velocities may be as high as $15 \mathrm{~m} / \mathrm{s}(50 \mathrm{ft} / \mathrm{s})$ or higher.

\subsubsection{Startup Feedwater System}

A special startup system is part of the main feedwater system in two Westinghouse plants, Wolf Creek and Callaway. The startup system provides heated feedwater to the steam generators during startup, hot standby, and shutdown operations of the plant. The startup system is provided as an option to feeding the steam generators with cold auxiliary feedwater, which is the practice at several PWR plants and is discussed in the next section. The main objective of the special startup system is to avoid thermal fatigue resulting from flow stratification and cracking of the steam generator feedwater nozzles and piping. ${ }^{1}$

A low flow, motor driven feedwater pump is installed within the special startup feedwater system to provide heated feedwater flow during startup and shutdown operations. The suction of the startup pump is taken from the heated condensate outlet of the steam generator blowdown regenerative heat exchanger, which also provides additional heating of the condensate. The maximum flow rate through the startup pump is limited to about $1.4 \times 10^{5} \mathrm{~kg} / \mathrm{h}\left(3 \times 10^{5} \mathrm{lb} / \mathrm{hr}\right.$, which is equal to $600 \mathrm{gpm}$ ) to prevent excessive tube vibrations in the steam generator blowdown regenerative heat exchanger. The startup pump discharges to the high-pressure feedwater heaters, which use steam generator blowdown flash tank steam as the heat source during a plant heatup. ${ }^{1}$

\footnotetext{
1 USNRC Technical Training Center. "Condensate and Feedwater," Westinghouse Technology Systems Manual, Volume 1, Chapter 7.2.
} 


\subsection{Auxiliary Feedwater System}

Figure 8 is a schematic of an auxiliary feedwater system for a 4-loop Westinghouse plant with the top-feed steam generators (Finn 1989). The auxiliary feedwater system consists of two subsystems, each capable of supplying $100 \%$ flow; one utilizes a turbine-driven pump and the other utilizes two motor-driven pumps. Both subsystems can deliver feedwater to all four steam generators. Some plants have only one motor-driven pump and at least one plant has a diesel-driven pump rather than a turbine-driven pump. The auxiliary feedwater flow initiates at the condensate storage tank and passes through three parallel, auxiliary feedwater pumps, and through individual check, control, and isolation valves for each of the three lines. Part of the flow from the pumps returns to the condensate storage tank via a recirculation line. The flow to the steam generators is usually controlled by means of an air-operated control valve in each line to the steam generators. Motor operated valves can be used should the air supply fail. Each auxiliary feedwater line connects to the main feedwater line somewhere between the feedwater nozzle and the first check valve upstream from the nozzle as shown in Figure 2.

The auxiliary feedwater condensate storage tank is typically at a temperature of about 38 to $50^{\circ} \mathrm{C}(100$ to $120^{\circ} \mathrm{F}$ ); however, the condensate storage tank can be at a temperature much lower than $38^{\circ} \mathrm{C}$ if located outdoors. The tank capacity varies, at one plant it is 500,000 gallons. A minimum of 170,000 gallons are required for 2 hours at hot standby, followed by 4 hours of cooldown. When the condensate storage tank is exhausted, the auxiliary feedwater system can be supplied from other sources such as the service water system.

During normal operation the auxiliary feedwater system is in standby. The motor-driven pumps generally start on either a steam generator low-low level signal, a safety injection signal, or a loss of electric power. The turbine-driven pump is started on either a low-low level in any two steam generators or a complete loss of electric power.
In some PWR plants, each auxiliary feedwater line has a minimum flow orifice installed, which restricts maximum flow through the line, especially when the steam generator is depressurized. In some PWR plants, an automatic isolation of the auxiliary feedwater line is provided if the steam generator is depressurized. In addition, an auxiliary feedwater line in a typical plant can be isolated manually or remotely from the control room.

The auxiliary (or emergency) feedwater lines in the $\mathrm{B} \& W$ plants introduce feedwater directly into the steam generators as shown in Figure 7(b).

\subsubsection{Preheater-Equipped Steam Generators}

Figure 9 is a schematic of a feedwater system for a Westinghouse plant with preheater-equipped steam generators. A 102-mm (4-in.) diameter preheater bypass line connects the main feedwater line to the auxiliary feedwater line outside the containment. In some plants there is no check valve on the auxiliary feedwater line inside the containment as shown in Figure 9, whereas in other plants there is one. The preheater bypass line serves two purposes. During startup, when the plant power is below approximately 15 to $20 \%$ of full power, all the feedwater flow to the steam generator is directed through the bypass line and then through the top-feed auxiliary feedwater nozzle. This eliminates the possibility of a condensation-induced water hammer in the preheater. At about $15 \%$ to $20 \%$ of full power, a very small amount of feedwater flow [for example, 27,000 to 36,000 $\mathrm{kg} / \mathrm{h}(60,000$ to $80,000 \mathrm{lb} / \mathrm{h}$ or 120 to $160 \mathrm{gpm})]$ to the steam generator is directed through the main feedwater nozzle via the main feedwater isolation valve (MFIV) bypass line (not shown in Figure 9). This small amount of feedwater flow slowly flushes the cold feedwater from the piping downstream of the main feedwater isolation valve and warms up the piping. This process of warming up is generally referred to as forward flushing. The main objective of warming up the feedwater piping is to prevent the cold feedwater from collapsing 


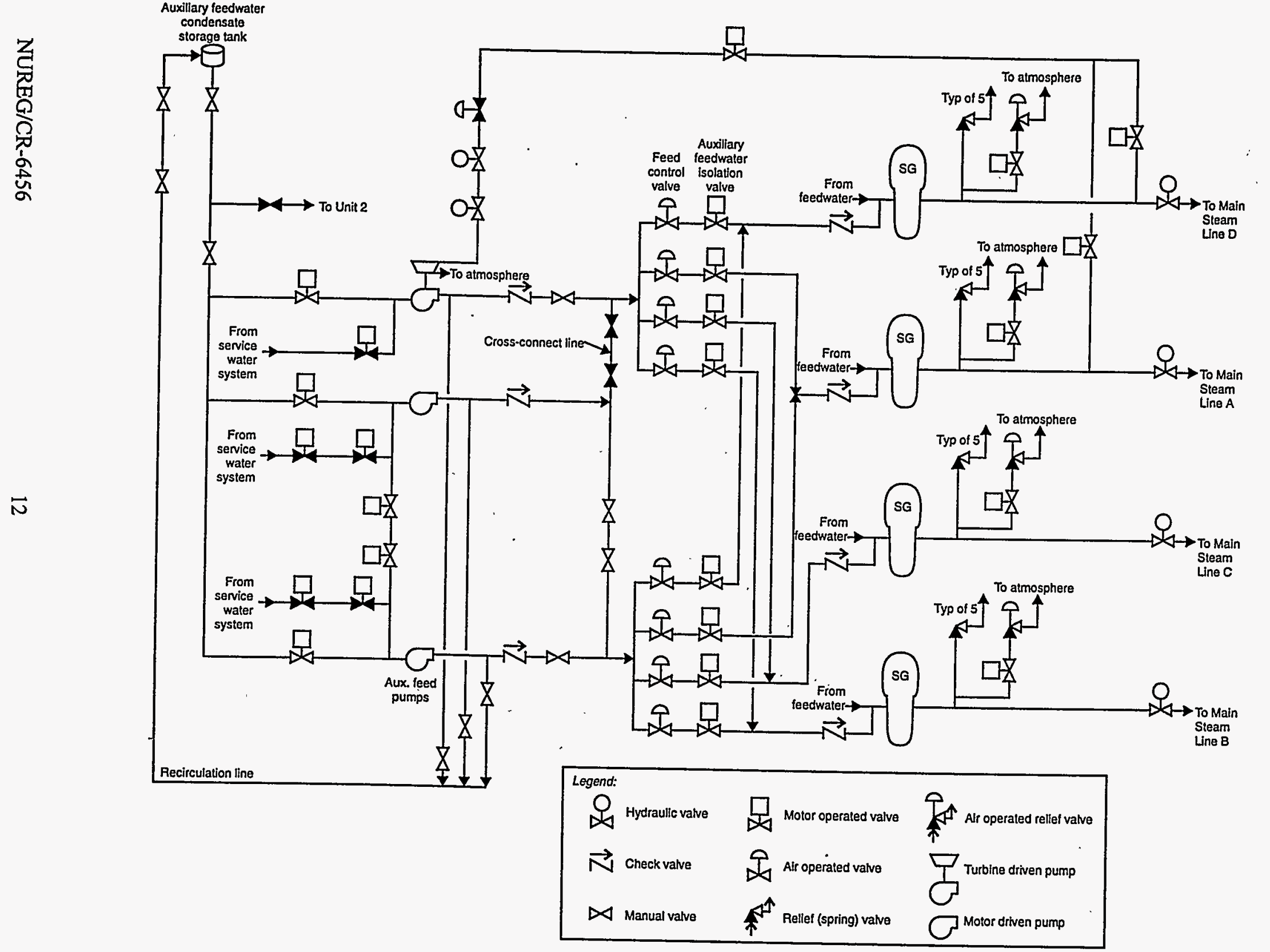

Figure 8. Schematic of an auxiliary feedwater system for a 4-loop Westinghouse plant with the top-feed steam generators (Finn 1987). 


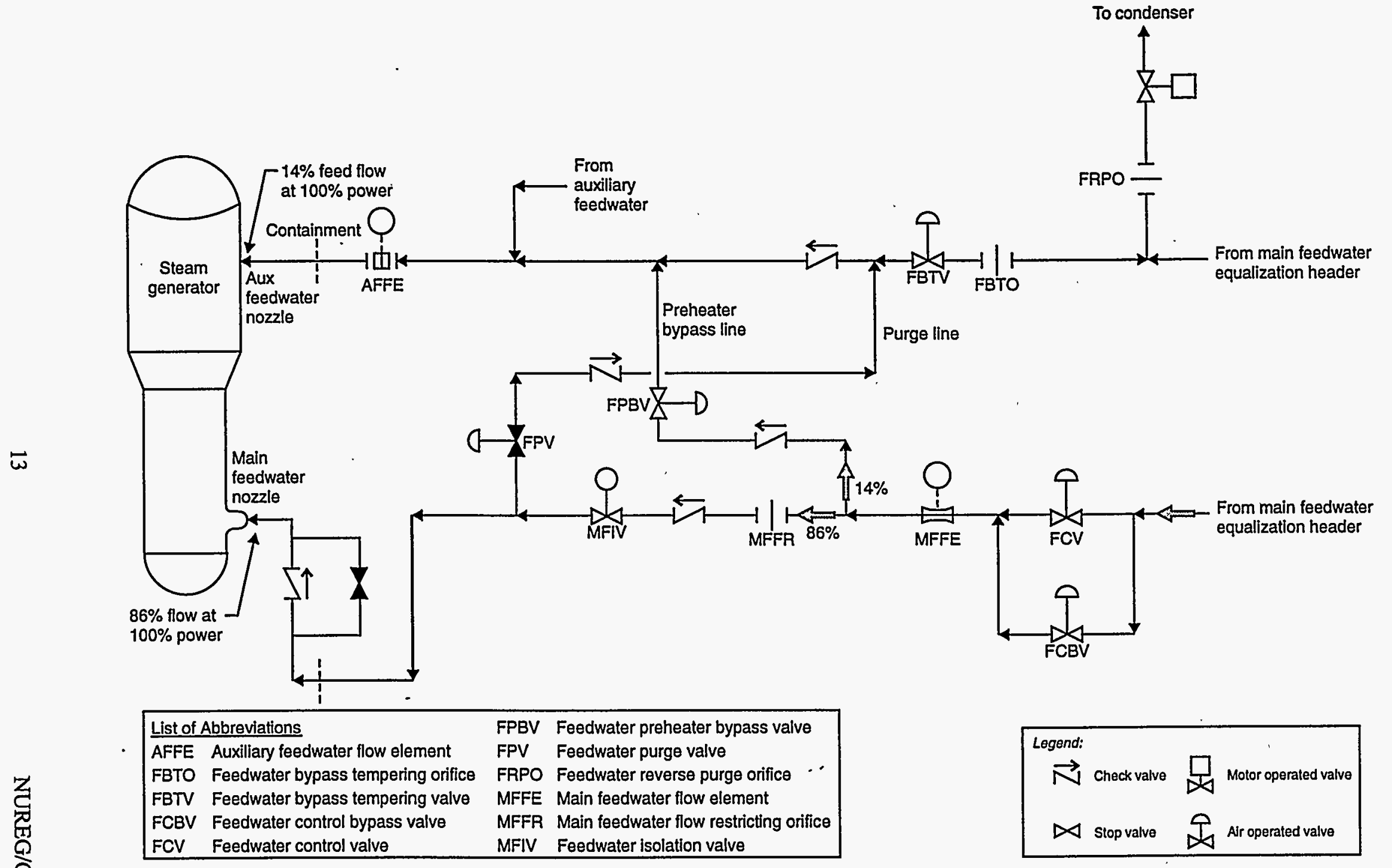

C253-WHT-896-08

Figure 9. Schematic of a feedwater system for a Westinghouse plant with steam generators equipped with preheaters. Courtesy of Dan Caldwell, Duke Power. 
any steam bubbles in the preheater section, which could cause water hammer damage to the preheater. The feedwater temperature at $15 \%$ power is about $129^{\circ} \mathrm{C}\left(265^{\circ} \mathrm{F}\right)$, whereas the corresponding temperature of the secondary coolant in the steam generator is about $293^{\circ} \mathrm{C}\left(560^{\circ} \mathrm{F}\right)$. So the small amount of feedwater flow used during forward flushing will cause thermal stratification in the feedwater nozzle and adjacent piping with a top-to-bottom temperature difference of about $164^{\circ} \mathrm{C}\left(295^{\circ} \mathrm{F}\right)$. Therefore, about 2000 cycles of stratified flow in the preheater-equipped steam generator feedwater nozzle have been allowed for in the design.

The second purpose for the preheater bypass line is to reduce the main feedwater flow into the preheater during operation above 15 to $20 \%$ of full power. This is accomplished by installing a flow orifice in the main feedwater line as shown in Figure 9, which directs a fraction of the main feedwater flow (for example, $14 \%$ in one plant) to

I V. N. Shah, Private conversation with J. L. Houtman, Westinghouse Electric Corporation, July 22, 1996. the auxiliary feedwater line. A check valve in the bypass line prevents flow from the auxiliary feedwater line to the main feedwater line. This splitting of the main feedwater flow during operation was not included in the original design. The main reason for this design change was to reduce fretting damage to the steam generator tubes in the preheater region of some Westinghouse-designed steam generators. However, the preheater bypass line and the portion of the auxiliary feedwater piping between the bypass line and the auxiliary feedwater nozzle were not designed for this operation and they are now exposed to high-velocity feedwater flow during normal operation and are susceptible to wall thinning. In some Combustion Engineering plants with preheater-equipped steam generators, a similar split-flow operation is carried out and the corresponding small-diameter piping is susceptible to wall thinning. Field experience related to this wall thinning is described in Section 6.4.1. 


\section{DESIGN, MATERIALS, AND FABRICATION}

This section describes the design and materials of the secondary system components adjacent to the feedwater nozzle, including the feedwater distribution system inside the steam generator. Relevant geometric characteristics of the feedwater nozzle are also described. Overall design configuration of the main and auxiliary feedwater systems is described in Section 2.

\subsection{Design Configuration}

The feedwater nozzles are part of the steam generator shell designed by the nuclear steam supply system (NSSS) vendors and, therefore, are basically similar. However, the feedwater piping was designed by the plant architect engineer and, as a result, the designs take several different forms (Hu, Houtman, and White, 1981). The piping may have a several-foot long horizontal section preceded by an upstream elbow, or it may have a 90-degree vertical downward elbow welded directly to the nozzle. Figure 10 shows the original configuration at the D. C. Cook plants (Westinghouse 4-loop plants) where the feedwater nozzle is welded to a 90-degree elbow. A reducer, transition piece, or safe end may be present between the nozzle and the elbow, the other end of which is welded to the feedwater piping.

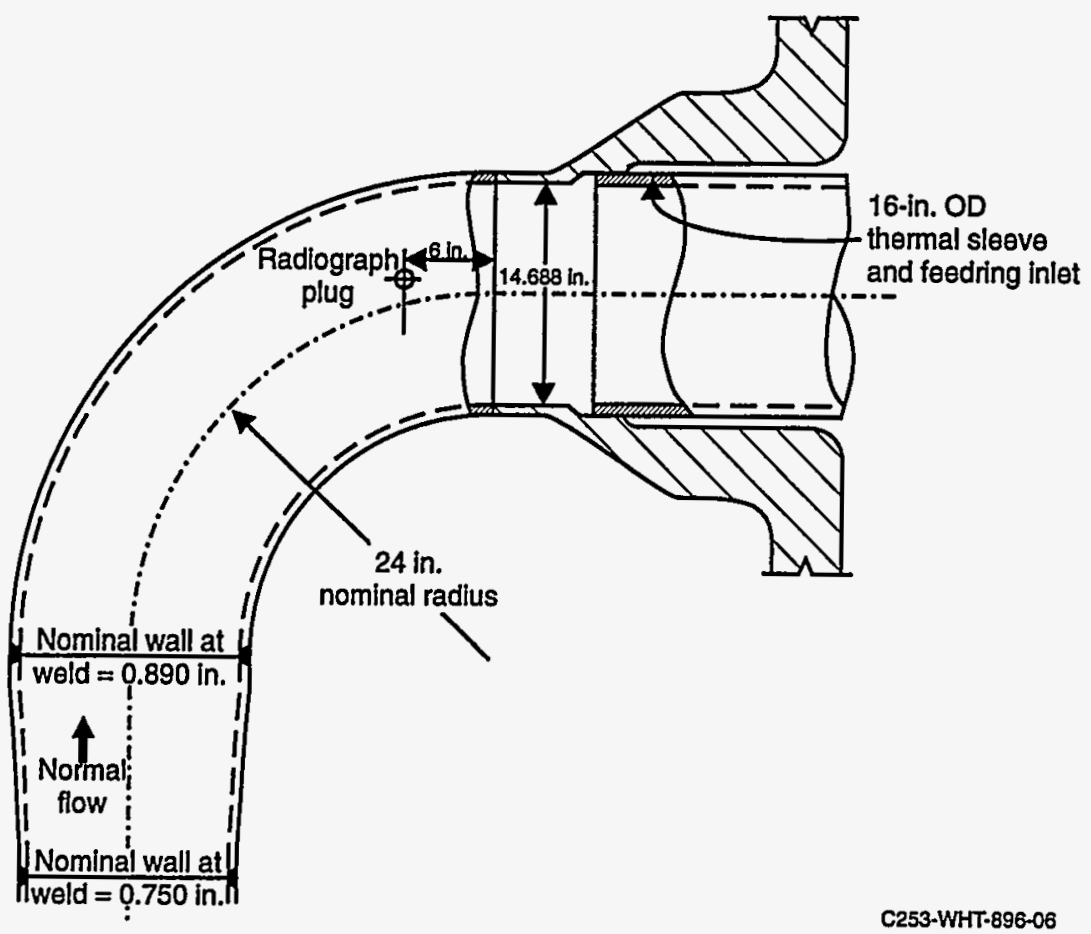

Figure 10. 90-degree elbow joining feedwater nozzle and piping in the original installation at D.C. Cook plants. 
Figure 11 shows the configuration of the San Onofre Unit 1 plant (Westinghouse 3-loop plant) where an expander (sometimes referred to as a reducer, but in this case the flow area is expanding), which acts as a transition piece, is placed between the piping and the nozzle. Figure 12 shows a typical Combustion Engineering feedwater nozzle welded to a safe end. As shown in Figure 13, some modified feedwater nozzle and piping designs have a thermal liner protecting the elbow and transition piece. Weld connections are described in Section 3.3. A radiograph plug (also called a gamma plug) is installed in the feedwater piping adjacent to the nozzle to allow access for single-wall radiography (see Figure 10).

In the Westinghouse design, the feedwater enters the steam generator through a thermal sleeve, passes through a feedring (sparger) and then Jtubes mounted on the top of the feedring, as shown in Figure 5, and is eventually distributed into the steam generator downcomer formed by the shell and the baffle around the steam generator tubes.
The J-tubes are bent so that the exiting feedwater is directed away from the steam generator shell. The distribution of the feedwater in the downcomer is not uniform; there are more J-tubes on the hot leg side of the steam generator than on the cold leg side. Because the J-tubes are mounted on the top of the feedring, rapid draining of the feedring is prevented in the event the steam generator water level falls below the feedring, thus reducing the potential for a water hammer event. In the early steam generators, sparging holes at the bottom of the feedrings were used to distribute the feedwater, which led to rapid drainage of the feedwater line when the feedring was uncovered. Consequently, the feedrings were modified to prevent rapid drainage. The modification included plugging the sparging holes on the underside of the feedring and installing J-tubes on the top of the ring. In fact, the steam generator feedrings were eventually modified at most of the operating Westinghouse units in response to the water hammer event at Indian Point 2 (Han and Anderson 1982).

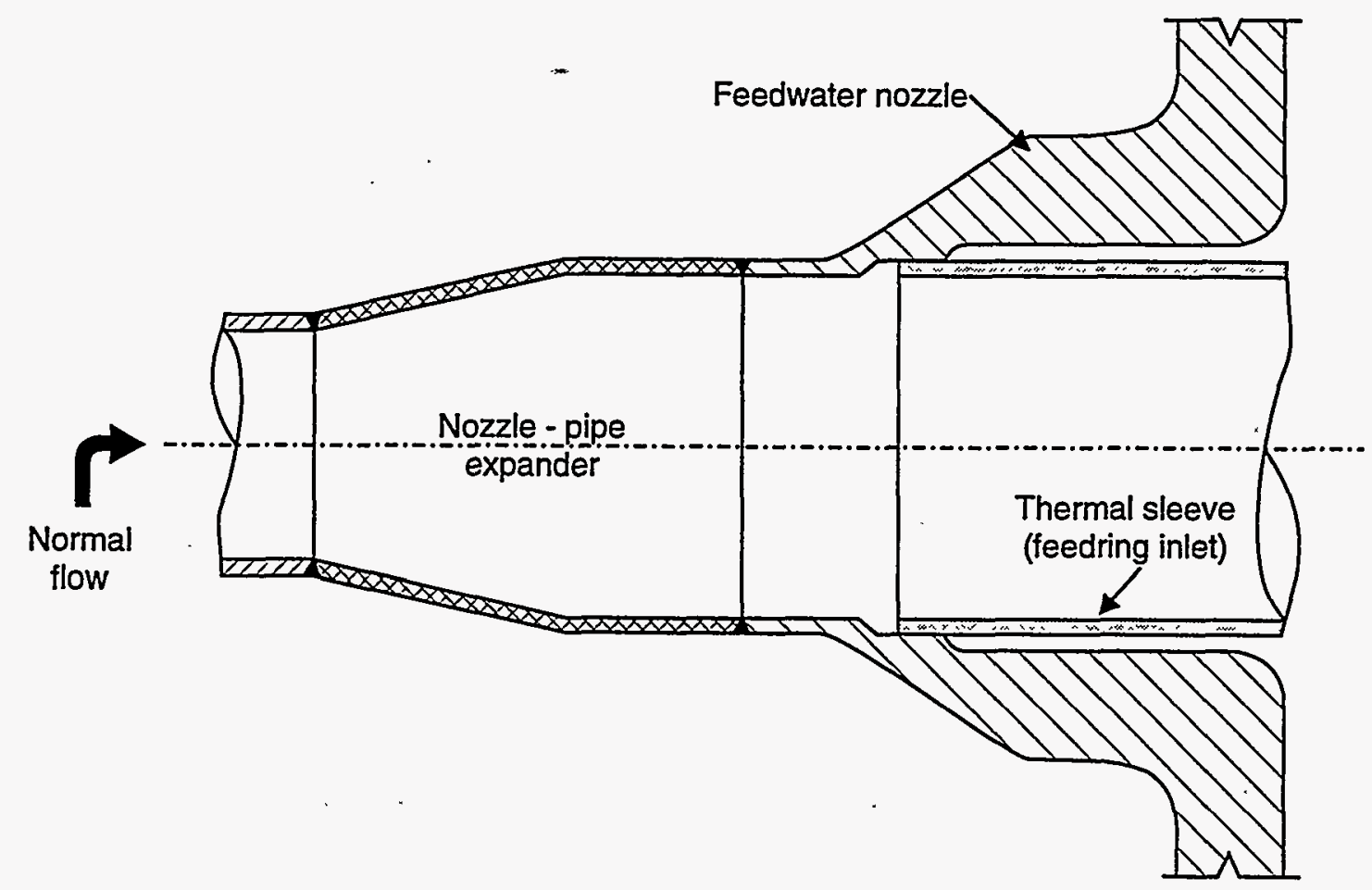

C144-WHT-1095-02

Figure 11. Expander joining feedwater nozzle and piping at the San Onofre 1 plant. 


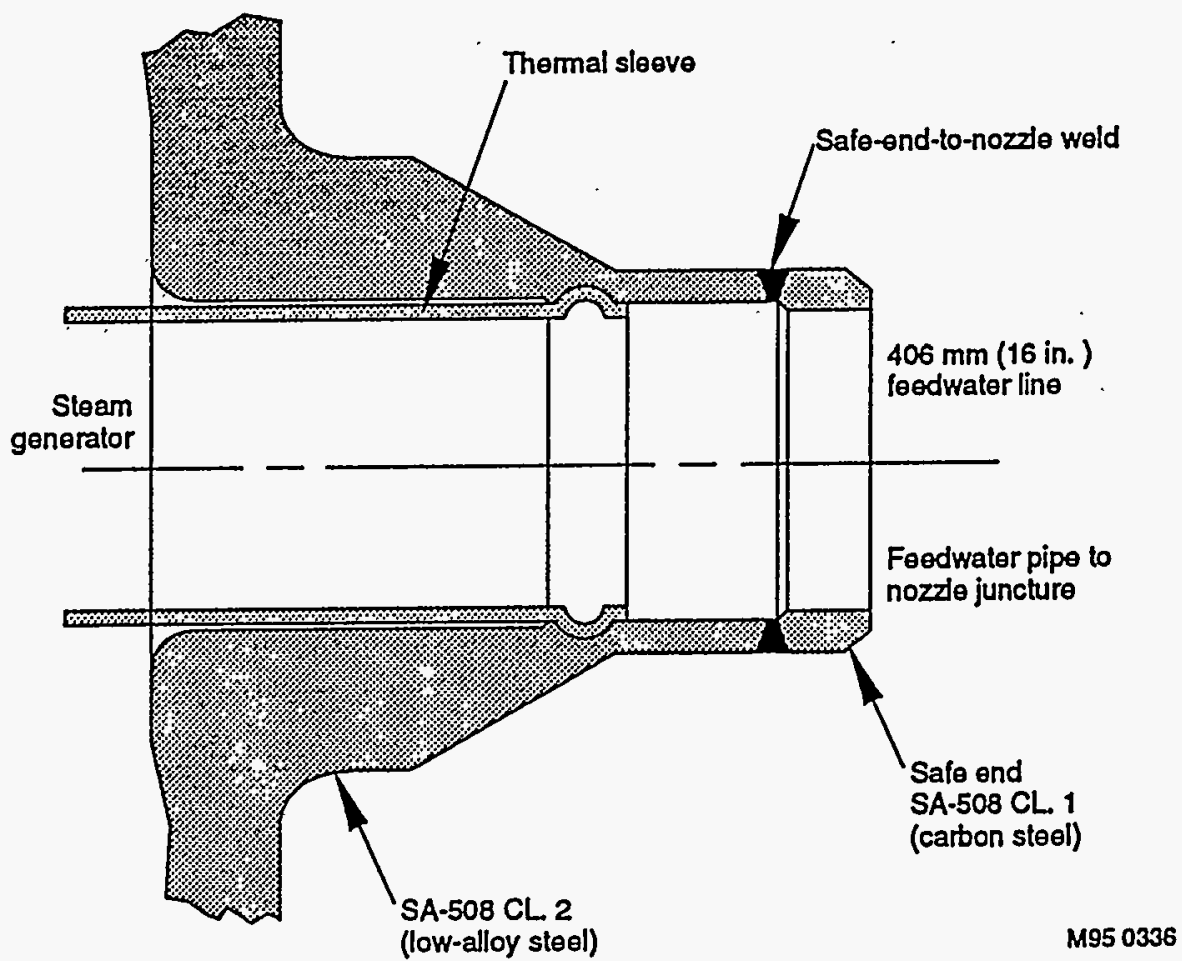

Figure 12. Sketch of a feedwater nozzle at a typical Combustion Engineering plant.

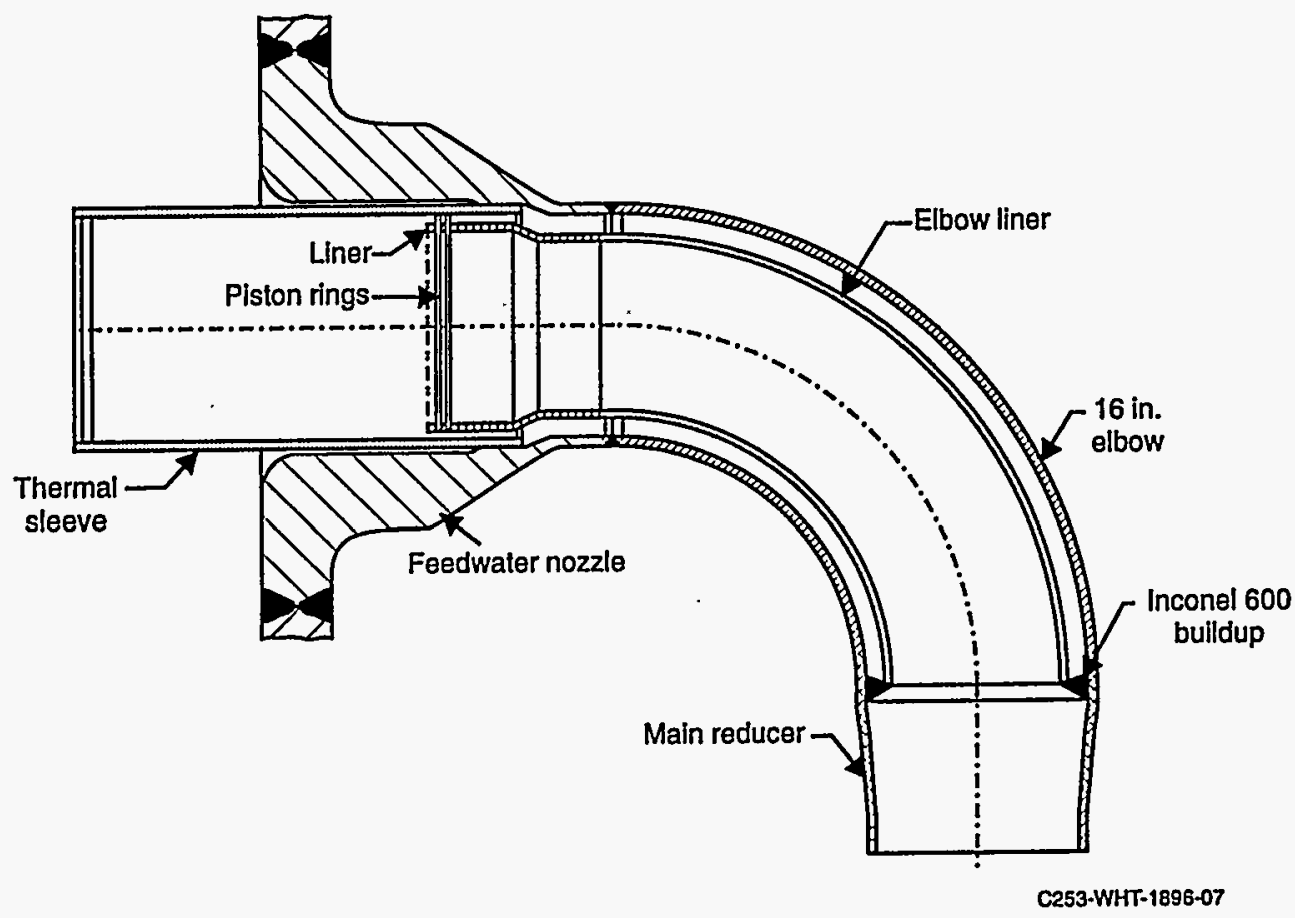

Figure 13. Modified feedwater nozzle and piping configuration at D.C. Cook plant. A thin liner protecting the counterbore and elbow from thermal stratification is installed. 
The distribution of the main feedwater into the Combustion Engineering steam generators is somewhat similar to that in the Westinghouse steam generators. Figure 14 shows the overall de- sign of the distribution system in the San Onofre 2 and 3 steam generators (Martin et al. 1990). The feedring consists of 12-in. diameter piping and is attached by two U-bolts at each of four supports

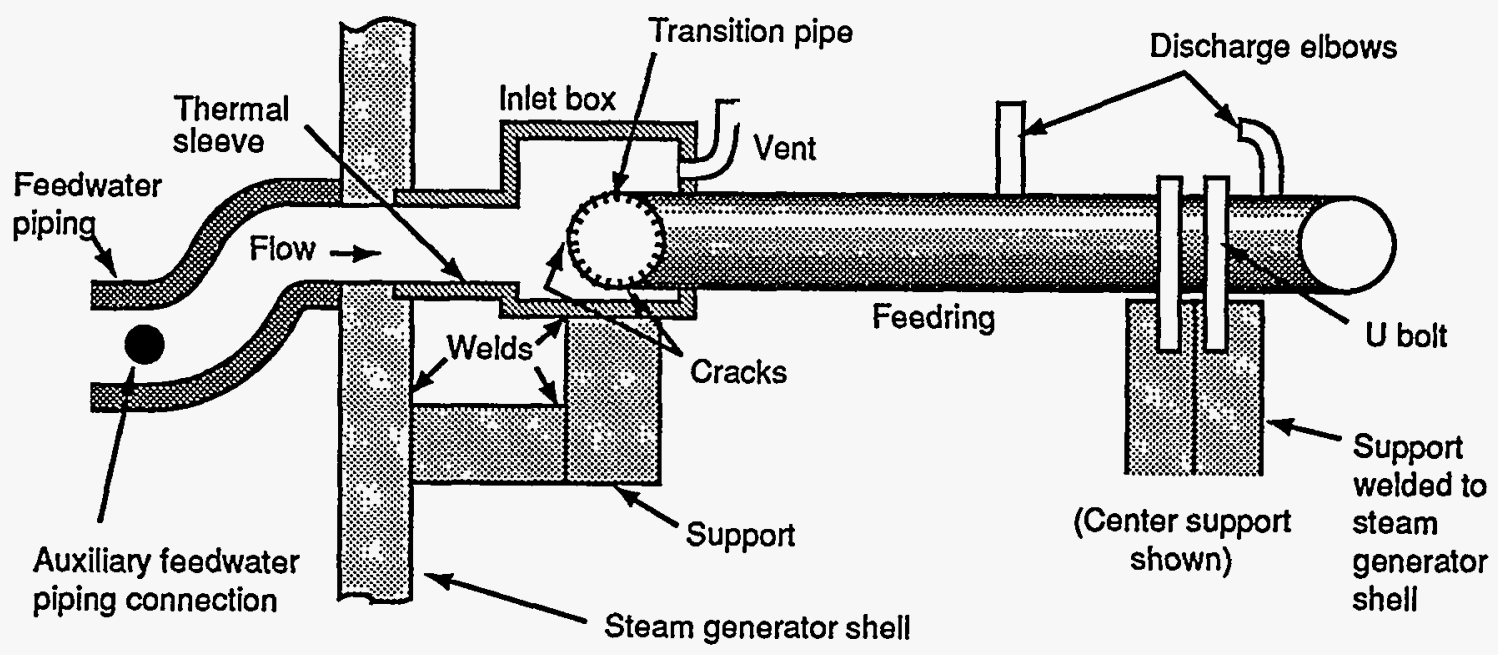

(a) Side view

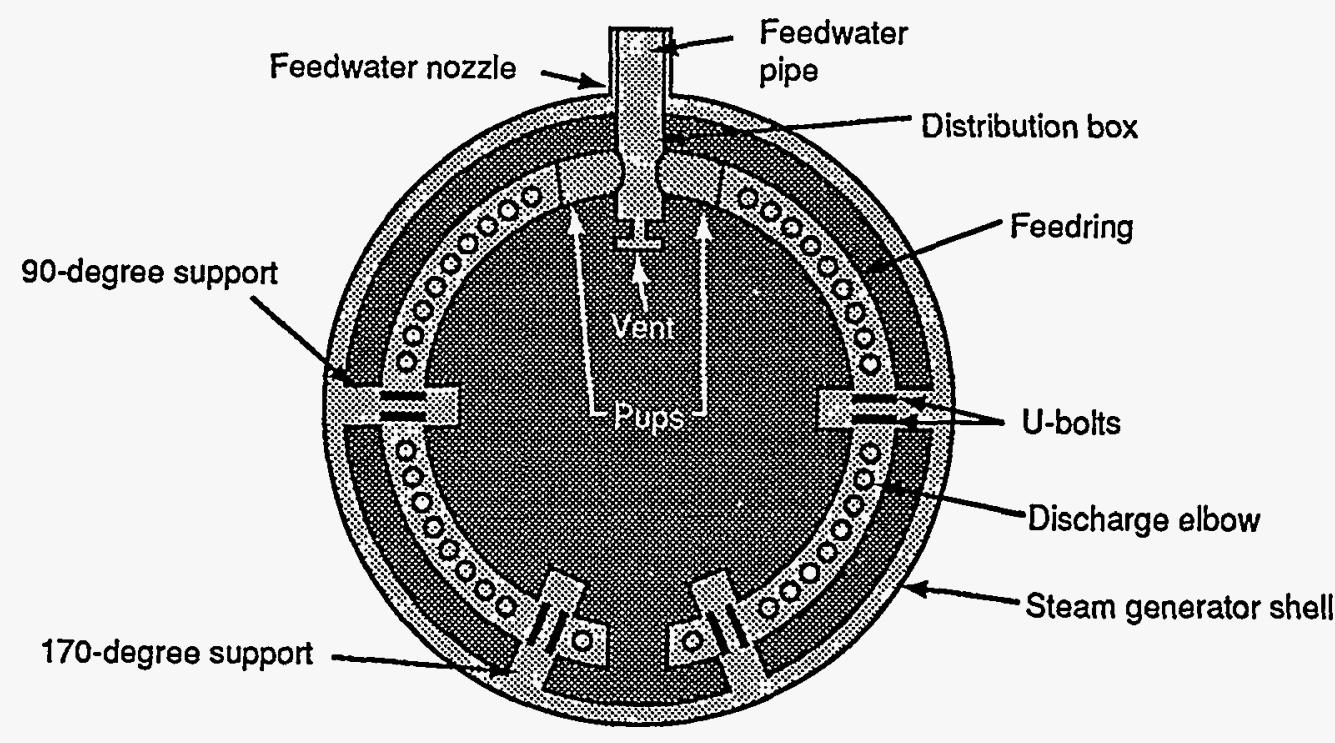

M96 0326

(b) Top view

Figure 14. San Onofre Units 2 and 3 feedwater distribution piping (Martin et al. 1990). Courtesy of E. Regala, Southern California Edition. 
that are welded to the shell wall. A 3-in. elbow and tee vent assembly is attached to the upper portion of the end of the distribution box toward the interior of the steam generator. Modifications have also been made in the feedwater distribution system in the San Onofre steam generators and are described in Section 6.4.2. Design modifications have also been made at other Combustion Engineering plants. For example, in May 1979 the Calvert Cliffs 1 steam generator feedring was modified by adding thirty-six 90-degree elbows to the top of the ring and plugging 72 discharge nozzles on the bottom of the ring to minimize the possibility of water hammer events.

The feedwater nozzle bore, blend radius, and steam generator shell inside surface directly beneath the nozzle are susceptible to thermal fatigue if there is any leakage of the feedwater through the joint between the nozzle and thermal sleeve. In the original Westinghouse steam generators, slip-on type thermal sleeves were tightly fitted in the feedwater nozzle, whereas in the replacement steam generators the sleeves are welded to the nozzle. The radial gap is typically 0.010 - to 0.020 in. at the slip fit and 0.25-in. over the remainder of the sleeve (Hu, Houtman, and White 1981).

Distribution of the main feedwater into the B\&W steam generators is different than that in the Westinghouse and Combustion Engineering steam generators. Water from the feedwater header enters each unit through 32 inlet pipes (risers) spaced around the steam generator shell, as shown in Figure 7. The header functions like a feedring located external to the steam generator shell and the risers function like J-tubes with respect to keeping the header full of water, that is, the feedwater inlet pipes are at a higher elevation than the main feedwater header and, therefore, the feedwater line cannot be rapidly drained when the steam generator water level falls below the elevation of the feedwater nozzles. Therefore, the feedwater lines in the $B \& W$ plants are not susceptible to water hammer damage. The feedwater entering the steam generator is sprayed into the downcomer. Steam, drawn into the downcomer through aspirating ports, heats the feedwater to the saturation temperature.

In some B\&W plants, the auxiliary feedwater header (feedring) is located external to the steam generator shell as shown in Figure 7(b). In other B\&W plants, the feedring for distributing the auxiliary feedwater was originally located inside the steam generator. However, the feedrings in three of these plants were found collapsed in the early 1980s. So as a corrective action, these auxiliary feedwater distribution systems were modified by replacing the internal feedrings with external auxiliary feedwater headers similar to the one shown in Figure 7(b) (Serkiz 1983).

\subsection{Materials}

At most U.S. plants, the majority of the main and auxiliary feedwater piping is made of carbon steel, typically SA-106 Grade B or SA-333 Grade 6 for straight portions of piping and SA-234 Grade WPB for elbows, as listed in Table 1. The feedring, J-tubes, and thermal sleeve are also made of SA-106 Grade B carbon steel. The steam generator shell is made of low-alloy ferritic steel plates, typically SA-533 Grade A, B, C, Class 1 or 2, or SA-302 Grade B materials. The feedwater nozzle is a low-alloy ferritic steel forging, SA-508 Class 2 material. Manganese sulfide inclusions are generally present in the carbon steel piping materials and low-alloy steel shell materials. These inclusions reduce the crack growth resistance of these materials. Because of the difference in the coefficients of thermal expansion between the thermal sleeve and nozzle materials, the design includes a small gap between these two components.

Carbon steel J-tubes with very low levels of chromium $(<0.01 \mathrm{wt} \%)$ as a trace element have experienced significant wall thinning because of flow-accelerated corrosion and, in some cases, resulted in failure (Roarty 1986). Several utilities have replaced their carbon steel J-tubes with Alloy $600 \mathrm{~J}$-tubes to address this problem. Some utilities have replaced their carbon steel J-tubes with Jtubes made of $2 \frac{1}{4} \mathrm{Cr}-1$ Mo material. 
Table 1. Typical materials and fabrication codes for feedwater piping (Florida Power \& Light).

\begin{tabular}{|c|c|c|}
\hline Piping & Material & Code \\
\hline $\begin{array}{l}\text { Feedwater nozzle to outermost } \\
\text { containment isolation valve }\end{array}$ & ASME SA-106, Grade B & ASME Section III, Class 2 \\
\hline Balance of piping & $\begin{array}{c}\text { ASME SA-155, } \\
\text { Grade KC-65 } \\
\text { ASME SA-106, Grade B }\end{array}$ & ANSI B31.1 \\
\hline Elbows & ASTM A-234, Grade WPB & ANSI B31.1 \\
\hline Auxiliary feedwater & ASME SA-106, Grade B & $\begin{array}{c}\text { ASME Section III, piping } \\
\text { Class } 2 \text { or Class 3,as applicable }\end{array}$ \\
\hline $\begin{array}{l}\text { The butt weld that connects the } \\
\text { nozzle to the feedwater piping jo } \\
\text { with a large difference in wall thick } \\
\text { the difference in the strength } \\
\text { materials. The steam generator no } \\
\text { made of SA-508 Class } 2 \text {, which h } \\
\text { stress of } 184 \mathrm{MPa}(26.7 \mathrm{ksi}) \\
\text { temperature of } 316^{\circ} \mathrm{C}\left(600^{\circ} \mathrm{F}\right) \text {. Th } \\
\text { typically SA- } 333 \mathrm{Grade} 6 \text { or SA-1 } \\
\text { an allowable stress of only } 119 \\
\text { Therefore, the pipe thickness is ap } \\
\text { times the nozzle thickness. Depen }\end{array}$ & $\begin{array}{l}\text { sign and th } \\
\text { inspection } \\
\text { geometric } \\
\text { nozzle and } \\
\text { has been } \\
\text { incidents. } \\
\text { the inside } \\
\text { weld wer } \\
\text { cracked cc } \\
\text { same desi } \\
\text { led to a } \\
\text { replaceme } \\
\text { configura } \\
\text { damaging } \\
\text { These red }\end{array}$ & $\begin{array}{l}\text { sign and the codes of construction, the weld and its } \\
\text { inspection varies from plant to plant. The } \\
\text { geometric discontinuity at the junction of the } \\
\text { nozzle and the pipe causes stress concentration and } \\
\text { has been the location for many of the cracking } \\
\text { incidents. As shown in Figure } 15 \text {, a counterbore at } \\
\text { the inside diameter, and a backing ring for the } \\
\text { weld were originally used. In many cases the } \\
\text { cracked component was replaced in kind with the } \\
\text { same design, which, as discussed in Section } 6 \text {, has } \\
\text { led to a second, and in some cases, a third } \\
\text { replacement. Consequently, redesigns of the } \\
\text { configuration have been proposed to reduce the } \\
\text { damaging effects of the piping discontinuity. } \\
\text { These redesigns are discussed in Sections } 6 \text { and } 9 \text {. }\end{array}$ \\
\hline
\end{tabular}

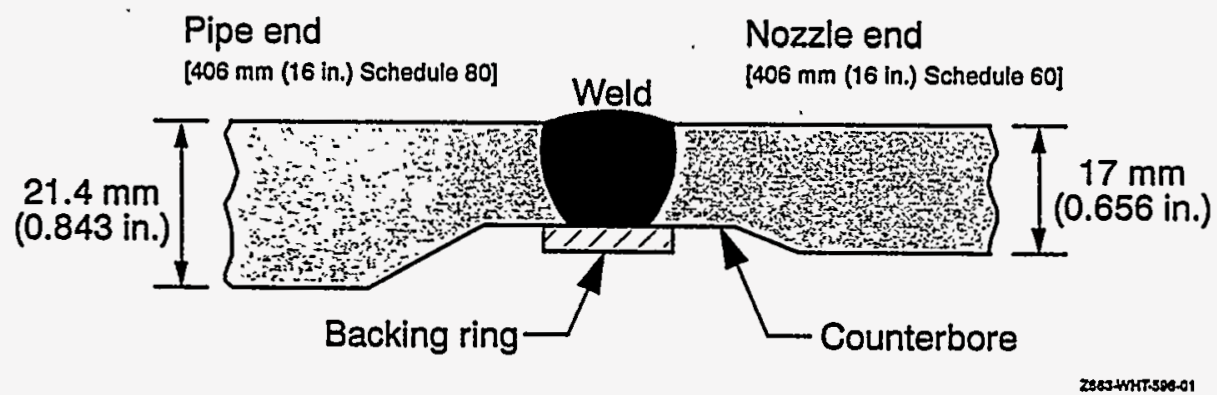

Figure 15. Typical PWR feedwater nozzle-to-pipe weld with a counterbore. 
The steam generators have been designed and constructed by the NSSS vendors according to the ASME Code. Before 1963, Section VIII of the Code was used. Section III, Nuclear Vessels, was first issued in 1963 and it and its successors have been used for nuclear vessel construction ever since. The vessel rules are generally applied to the end of the nozzle. Feedwater piping is designed by the architect engineer. Before 1969, USAS B31.1 was used, from 1969 to 1971 USAS B31.7 was used, and since 1971 Section III of the ASME Code has been used. The ASME Code essentially incorporated the piping rules of B31.7; however, the requirements for Section III are more stringent than those for B31.7. Plants designed before 1971 followed different codes and standards for different vessel and piping components. For example, in the Sequoyah plants, designed before 1971, most of the nuclear equipment, including the steam generators, was procured by Westinghouse. Its code of record is ASME Section III, 1968 edition (Bressler 1994). The piping was designed and procured by the architect engineer, National Valve \& Manufacturing Company. The main steam pip- ing was procured to USAS B31.1.0-1967, but most other piping, including the feedwater piping, was procured to B31.7-1969, with no addenda.

There are several configurations of the first upstream weld from the steam generator in different PWRs. For example, at the San Onofre 1 plant, the first upstream weld was a nozzle-to-expander weld, and the next weld was an expander-to-pipe weld as shown in Figure 11. At the D. C. Cook plants, the pipe elbow is welded to the nozzle as shown in Figure 10. As shown in Figure 16, at the Sequoyah plants, TVA chose to install a transition piece of SA-508 Class 2 material, which was shop welded to the piping using a qualified P3 to P1 weld procedure. ${ }^{1}$ The field weld between the nozzle and the transition piece, which have essentially uniform wall thicknesses, was made using a qualified $\mathrm{P} 3$ to $\mathrm{P} 3$ weld procedure. If the field weld was within the limits of reinforcement for the nozzle, then the weld had to meet Section III requirements. If it was located outside the limits of reinforcement, then it was a pipe weld and had to meet $B 31.7$ requirements.

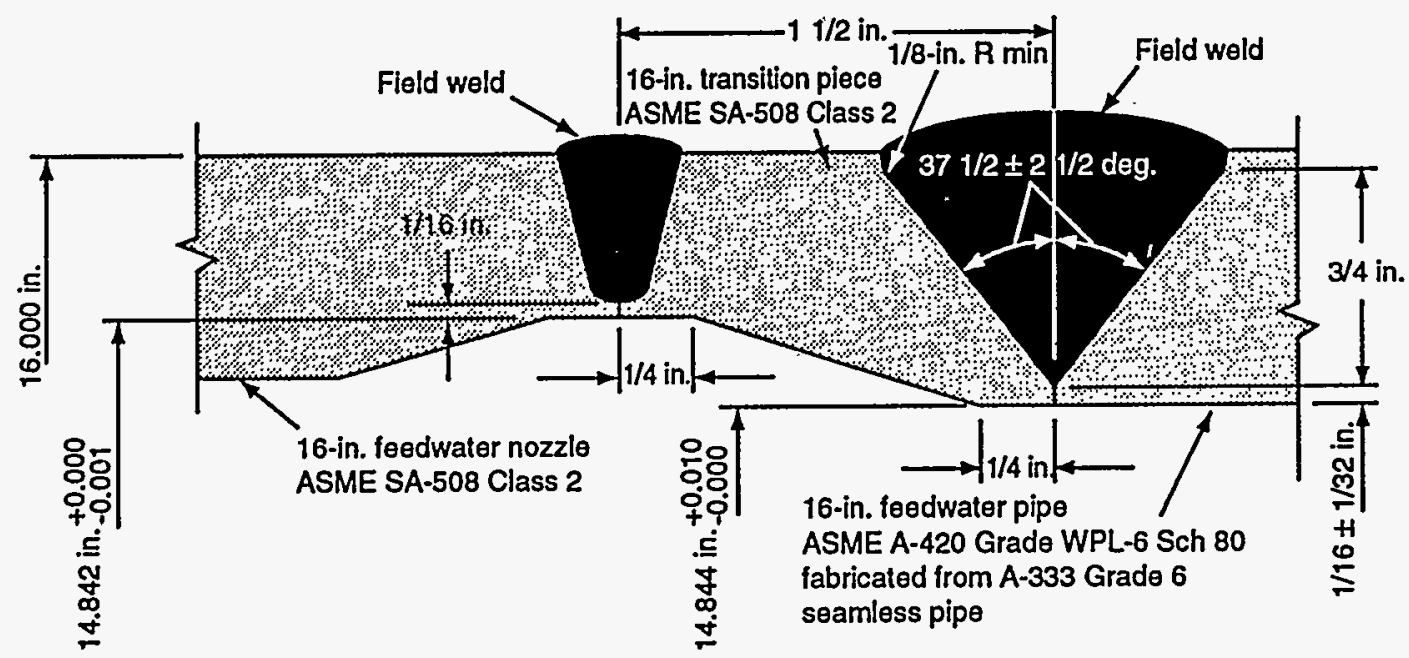

M950197

Figure 16. Construction drawing of transition piece for Sequoyah Units 1 and 2 (TVA 1992b).

\footnotetext{
To reduce the number of welding procedure qualifications required, base metals have been assigned P-numbers. These assignments are based essentially on comparable base metal characteristics, such as composition, weldability, and mechanical properties. The P-number for SA-106 steel is 1 and for SA-533B, it is 3 (ASME 1995b).
} 
Figure 17 shows configurations for the Diablo Canyon nozzle-to-pipe and pipe-to-pipe welds (Cofie et al., 1994). The 230-mm (16-in.), Schedule 80 piping [nominal thickness $21.4 \mathrm{~mm}$
( 0.843 in.)] meets the Schedule 60 nozzle [nominal thickness $16.7 \mathrm{~mm}(0.656 \mathrm{in}$.$) ]. The weld prepar-$ tion counterbore reduces the thickness, as measured in one nozzle, to as low as $13.7 \mathrm{~mm}(0.54 \mathrm{in}$.).

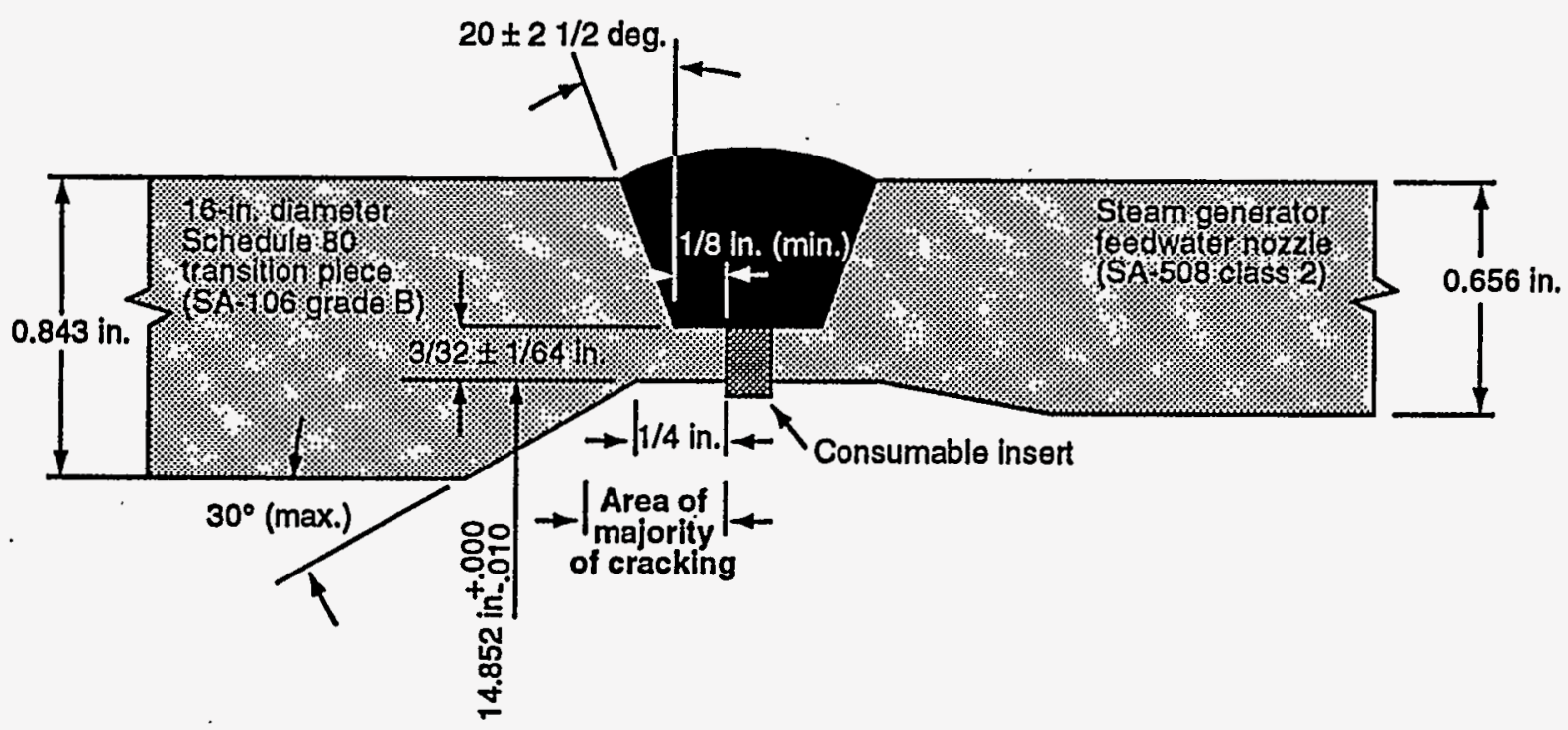

(a) Field Butt Weld Detail - Feedwater transition piece-to-nozzle joint

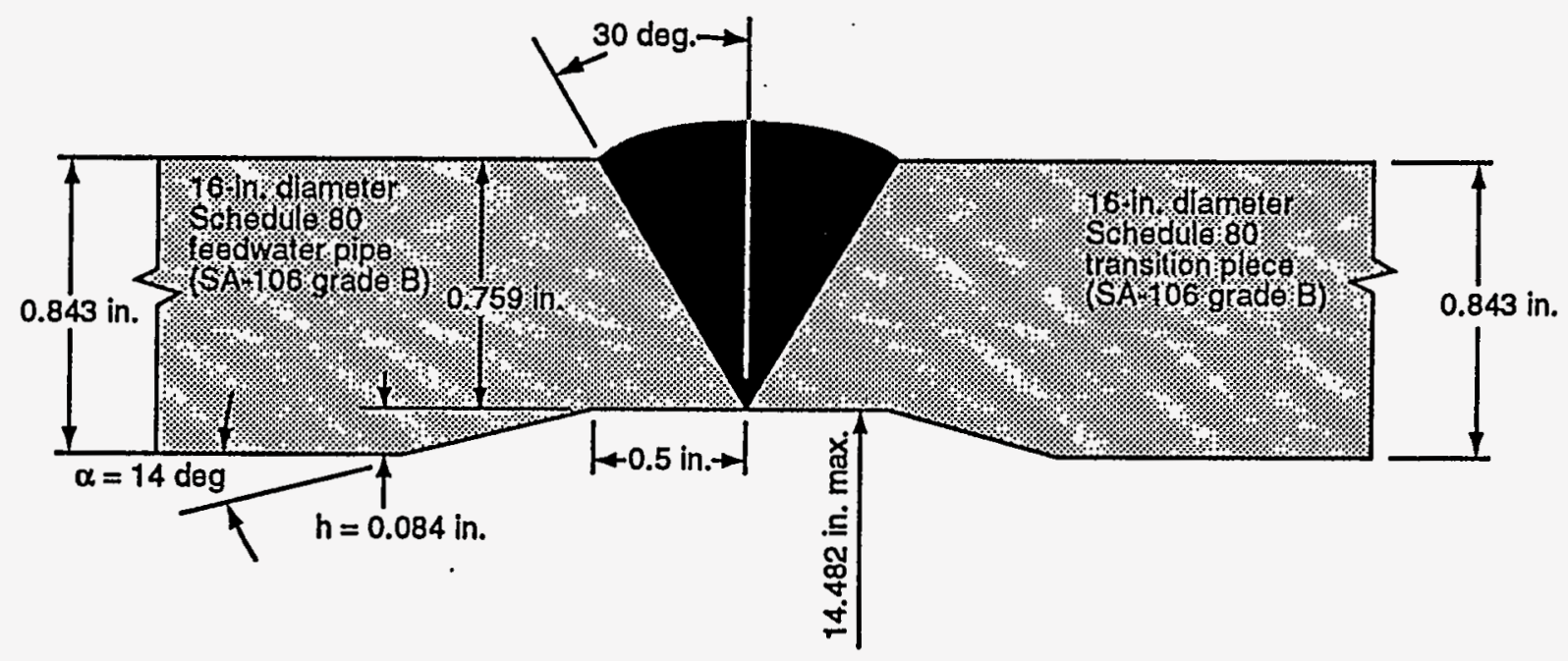

(b) Typical Butt Weld Detail - Feedwater transition piece-to-pipe connection

M96 0325

Figure 17. Construction drawings for feedwater nozzle and piping welds at Diablo Canyon Units 1 and 2 (Cofie et al. 1994). Copyright American Society of Mechanical Engineers; reprinted with permission. 
The thickness transition is significantly more severe than for a typical piping system butt weld and introduces a high stress concentration. The field weld sometimes makes the discontinuity more severe, resulting in a higher stress concentration. For example, as shown in Figure 18, the notch caused by the weld penetration makes an angle $\beta$ between the nozzle and the transition piece which is smaller than the design angle $\alpha$; this causes a stress concentration greater than the design value. This higher stress concentration factor contributed to the initiation of a primary crack at this location (discussed in Section 6.3.1).
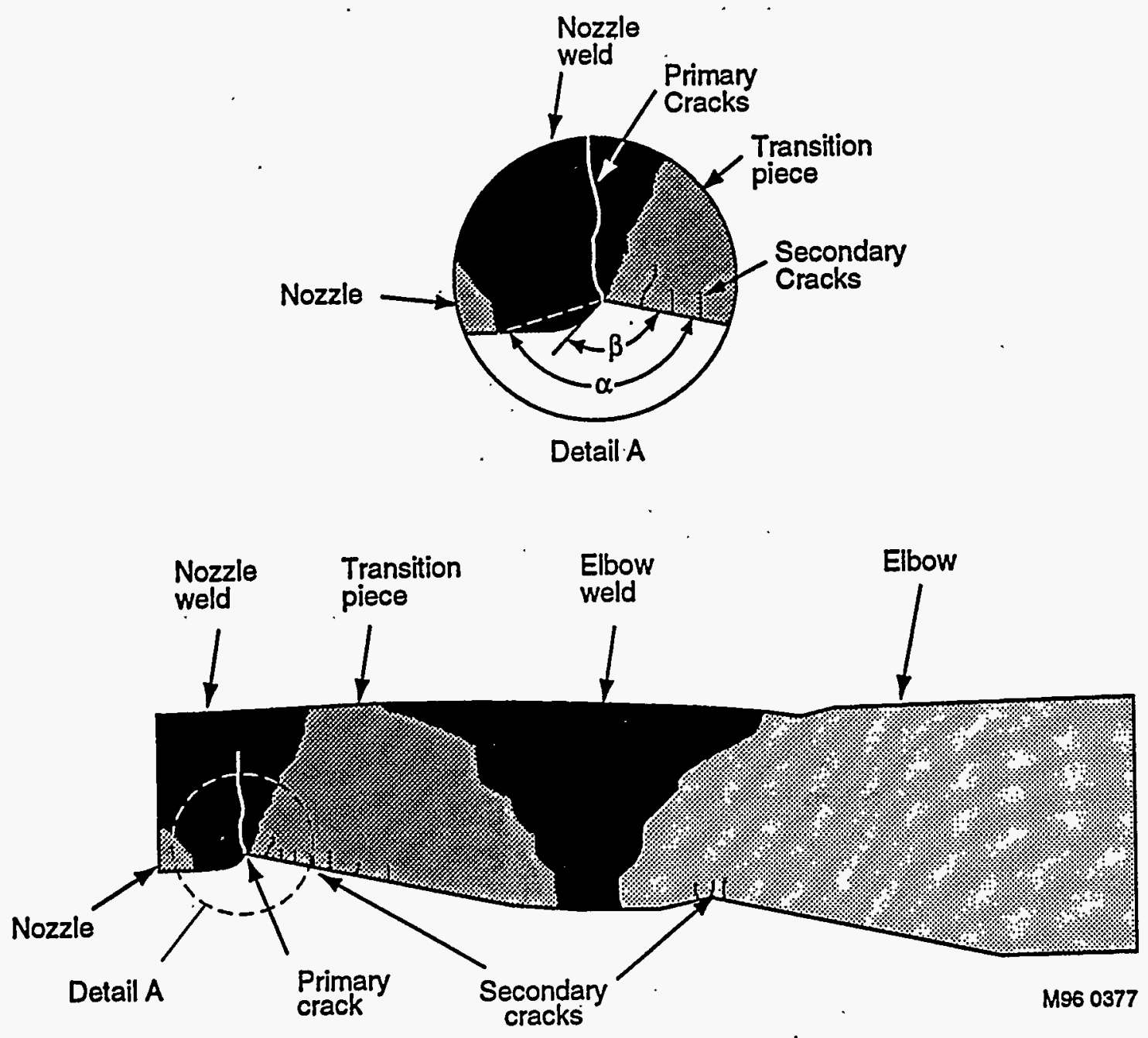

Figure 18. Geometric discontinuity introduced by the field welding between the feedwater nozzle and the transition piece (TVA 1992) (modified). 


\section{OPERATING TRANSIENTS AND ENVIRONMENT}

The feedwater system experiences five different major transient conditions as the plant starts from cold shutdown. These conditions, corresponding reactor coolant system (RCS) temperatures, and the modes of operation for a Westinghouse plant are as follows:

- Cold Shutdown RCS temperature $<93^{\circ} \mathrm{C}\left(200^{\circ} \mathrm{F}\right)-$ Mode 5

- Hot Shutdown RCS temperature 93 to $177^{\circ} \mathrm{C}\left(200\right.$ to $\left.350^{\circ} \mathrm{F}\right)$ - Mode 4

- Hot Standby RCS temperature 177 to $292^{\circ} \mathrm{C}\left(350\right.$ to $\left.557^{\circ} \mathrm{F}\right)$ - Mode 3

- Startup, i.e., reactor critical RCS temperature $292^{\circ} \mathrm{C}\left(557^{\circ} \mathrm{F}\right)$, power $<5 \%$ - Mode 2

- $\quad$ Power Operations, power $>5 \%$ Mode 1.

The reactor coolant system is vented to remove gases during cold shutdown (Mode 5 operation) and then a steam bubble is drawn in the pressurizer. The reactor coolant pumps are idle, the residual heat removal pumps are running, decay heat is removed by the residual heat removal system, and the steam generators are in wet layup. No secondary systems are in operation with an exception of one circulating water pump. Thus there is no secondary flow or transients and, therefore, no fatigue damage to the feedwater nozzle and adjacent piping.

The reactor coolant pumps are started during hot shutdown (Mode 4 operation) and the residual heat removal pumps are turned off, since the reactor coolant pumps will provide flow through the residual heat removal system. At approximately $105^{\circ} \mathrm{C}\left(220^{\circ} \mathrm{F}\right)$, steam begins to form in the steam generators. The condensate and circulation systems are started, and the steam lines are warmed. However, the feedwater pumps have not been started and the condensate flow through the idle feed pumps is returned to the condenser.

The residual heat removal system is secured once the reactor coolant system temperature reaches $177^{\circ} \mathrm{C}\left(350^{\circ} \mathrm{F}\right)$, and hot standby conditions (Mode 3 operation) are established. Turbine warmup begins when steam generator pressure reaches 7.53 $\mathrm{MPa}$ (1092 psig), the automatic action of the steam dumps removes additional heat from the primary system. As the steam dumps are opened to increase steam flow, auxiliary feedwater flow to the steam generators is also increased to maintain the water level in the steam generators. The reactor coolant system temperature is raised to $292^{\circ} \mathrm{C}\left(557^{\circ} \mathrm{F}\right)$.

The reactor is taken critical as startup (Mode 2 operation) occurs. The first main feedwater pump is started when at least $2 \%$ power is reached. Once the power is above 5\%, the reactor is in Mode 1 operation. When the power reaches $15 \%$, the turbine is rolled and the steam dumps are closed. The main feedwater regulating valves are placed on automatic prior to increasing the load above $20 \%$. The main feedwater pump speed control is placed in automatic when the main feed regulating valves are controlling steam generator levels. During loading from 20 to $100 \%$ power, additional secondary pumps are placed on line, including all the main feedwater pumps.

\subsection{Auxiliary Feedwater Operation}

The auxiliary feedwater system is used to supply the steam generators during hot standby (Mode 3) and startup (Mode 2). The relatively cold auxiliary feedwater flow is low and unsteady. In some plants it can be operated in both manual and automatic modes. Under low feedwater flow conditions, the flow in horizontal sections of the pipe becomes stratified (flow stratification is discussed in Section 7). 
Figure 19 shows such a low-flow condition during hot standby. The upper portion of the pipe fills with hot steam or water from the steam generator while the bottom portion is filled with relatively cold auxiliary feedwater. The figure also shows the general location of fatigue cracks produced by thermal stratification. The height of the interface layer between cold and hot coolants in the pipe depends on the auxiliary feedwater flow rate, the temperature difference between the coolants, and the piping layout. The height increases as the auxiliary feedwater flow rate increases, and it fluctuates as the flow rate is increased and decreased to maintain the steam generator water level. While the steam dumps are cycling open and closed, there is a corresponding on and off cycling of the auxiliary feedwater. When the auxiliary feedwater flow rate is increased above a threshold flow rate, the cross section of the horizontal piping connected to the nozzle becomes completely filled with cold feedwater, and thermal stratification is no longer present. The threshold flow rate depends on the same parameters on which the height of the interface layer depends. Therefore, the threshold flow rates are different at different plants. For example, the threshold flow rate at the Diablo Canyon plants is about $757 \mathrm{l} / \mathrm{min}$ $(200 \mathrm{gpm})$. The threshold flow rate is higher, about $1514 \mathrm{l} / \mathrm{min}(400 \mathrm{gpm})$ at the Sequoyah plants, where a $757 \mathrm{l} / \mathrm{min}(200 \mathrm{gpm})$ flow rate leads to a stratified flow condition with an interface at the center of the pipe cross section.

Auxiliary feedwater transients vary from plant to plant, and even from startup to startup, depending upon the time the plant is in Modes 3, 4, and 5 operations, the steam generator temperature, and whether the mode of operation for the auxiliary feedwater system is automatic or manual. Typical auxiliary feedwater evolutions including durations and flow rates for the Diablo Canyon units are listed in Table 2 (Peterson 1992). For the period covered in the table, the total time spent in Modes 2 and 3 was 339.5 days for Unit 1 and 238.6 days for Unit 2.

Most plants use a single-element auxiliary feedwater flow controller (steam generator level). For example, the automatic control for Diablo Canyon auxiliary feedwater system was designed for minimum flow rates on the order of $832 \mathrm{l} / \mathrm{min}$ $(220 \mathrm{gpm})$ per steam generator, which is required during accident conditions (PG\&E 1992). Since the required auxiliary feedwater flow during hot standby and startup is typically less than $832 \mathrm{l} / \mathrm{min}$, on/off operation of the auxiliary feed water system occurs under automatic control.

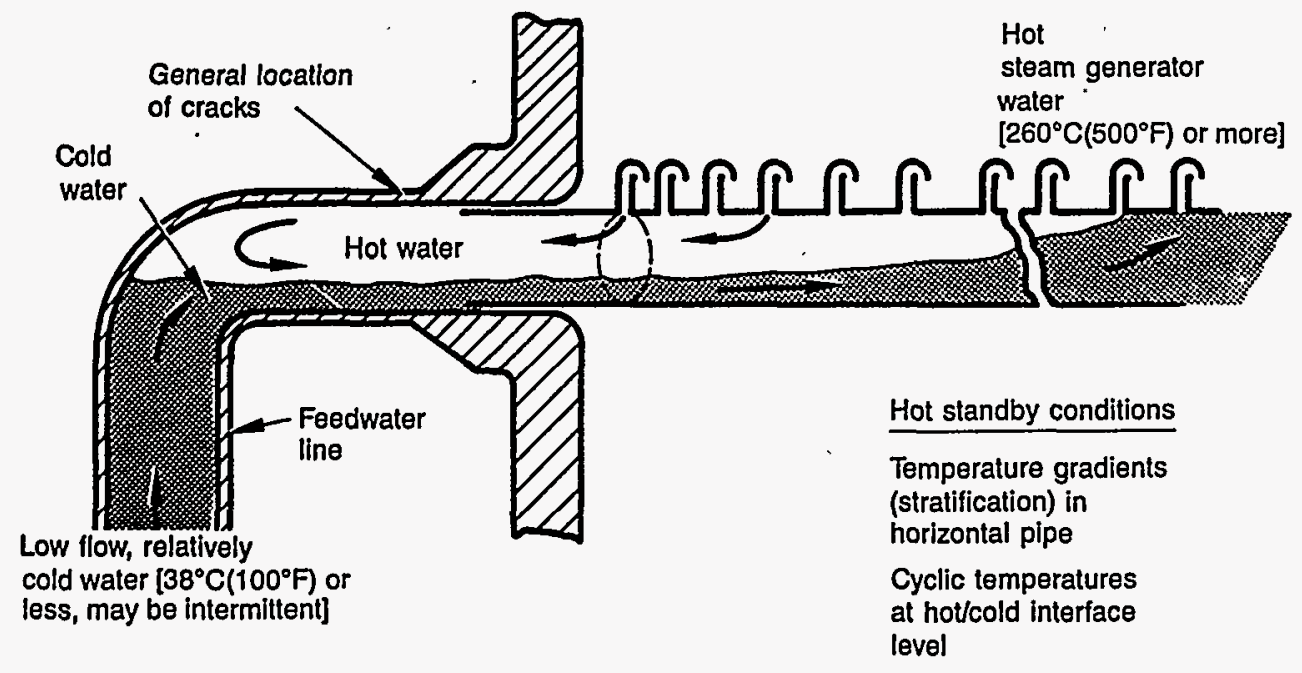

Figure 19. Flow stratification in PWR feedwater nozzle during low flow conditions (USNRC 1980). 
Table 2. Typical Diablo Canyon auxiliary feedwater evolutions.

\begin{tabular}{|c|c|c|}
\hline Evolution & Duration & Auxiliary Feedwater Flow \\
\hline Reactor trip recovery & 20 to 30 minutes & Approximately $16911 / \mathrm{m}(400 \mathrm{gpm})$ \\
\hline $\begin{array}{l}\text { Holding at Mode } 3 \text { from a forced } \\
\text { outage }\end{array}$ & Typically 2 to 4 days & Steady \\
\hline $\begin{array}{l}\text { Shutdown (cooldown) to RHR } \\
\text { conditions }\end{array}$ & $\begin{array}{l}\text { Bóration (8 hours) } \\
\text { Cooldown, } 286 \text { to } 149^{\circ} \mathrm{C} \\
\left(547 \text { to } 300^{\circ} \mathrm{F}\right)(8 \text { hours) } \\
\text { Transfer to RHR (8 hours) }\end{array}$ & $\begin{array}{c}\text { Initially steady } \\
0 \text { to } 85 \mathrm{l} / \mathrm{m}(20 \mathrm{gpm}) \\
\text { as RHR transfer nears }\end{array}$ \\
\hline Startup from a refueling outage & $\begin{array}{l}\text { Heatup to Mode } 3 \text { ( } 20 \text { hours) } \\
\text { Mode } 3 \text { ( } 72 \text { hours) } \\
\text { Mode } 2 \text { on AFW ( } 48 \text { hours) }\end{array}$ & 0 to $169 \mathrm{l} / \mathrm{m}(40 \mathrm{gpm})$ \\
\hline Hot functional testing & $\begin{array}{l}91 \text { days for Unit } 1 \\
40 \text { days for Unit } 2\end{array}$ & $\begin{array}{c}\text { Similar to startup from refueling } \\
\text { outage }\end{array}$ \\
\hline
\end{tabular}

Figure 20 shows a typical history of auxiliary feedwater flow rates measured at Sequoyah Unit 1 during Modes 2 and 3 operation (Cofie et al al. 1994). The periods of manual auxiliary feedwater flow exhibit relatively small fluctuations around a base flow rate of 277 to $302 \mathrm{l} / \mathrm{min}$ (60 to

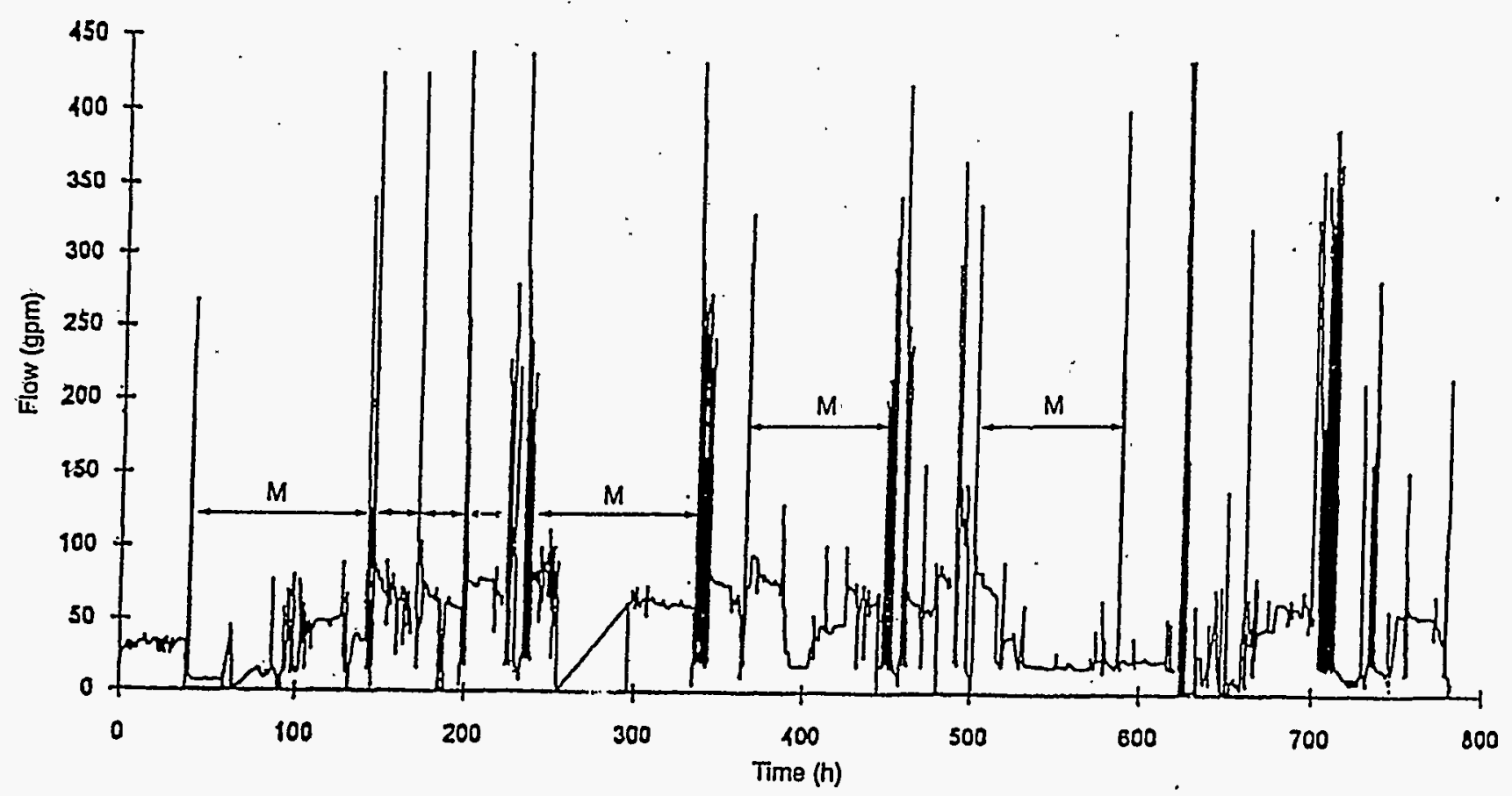

Figure 20. Auxiliary feedwater flow for Sequoyah Unit 1 showing automatic and manual controls (Cofie et at. 1994). Copyright American Society for Mechanical Engineers; reprinted with permission. 
$80 \mathrm{gpm}$ ). However, automatic auxiliary feedwater control resulted in large flow cycles from 0 to 757 $1514 \mathrm{l} / \mathrm{min}(200-400 \mathrm{gpm})$ at frequencies of about 2 cycles/h. Though the automatic control accounted for only $13 \%$ of the total time, severe fluctuations in the flow rates occurred during automatic control that caused significant fatigue damage. Figure 21 shows typical periods of automatic and manual feedwater flows at Sequoyah Unit 2 (Shvarts et al. 1994). Obviously, the time of automatic auxiliary feedwater use is important for fatigue crack growth.

\subsection{Environment}

The typical values of feedwater pressure and temperature at the steam generator inlet during normal operation range from 5.5 to $7.9 \mathrm{MPa}(800$ to $1150 \mathrm{psia})$ and 210 to $238^{\circ} \mathrm{C}\left(410\right.$ to $\left.460^{\circ} \mathrm{F}\right)$. However, auxiliary feedwater flow initiates from the condensate storage tank, in which the water may be at $38^{\circ} \mathrm{C}\left(100^{\circ} \mathrm{F}\right)$ or less. Feedwater temperatures at Diablo Canyon are 21 to $30^{\circ} \mathrm{C}$ ( 70 to $100^{\circ} \mathrm{F}$ ) during Modes 2 and 3 operation when the steam generator temperature is greater than $177^{\circ} \mathrm{C}\left(350^{\circ} \mathrm{F}\right)$ (PG\&E 1992). For plants in colder regions, for example, Indian Point, the auxiliary feedwater temperature could go as low as $5^{\circ} \mathrm{C}\left(40^{\circ} \mathrm{F}\right)$ during winter months. Some plants have added preheaters for the auxiliary feedwater to lessen the temperature difference between the feedwater and steam generator.

A pH range of 8.5 to 9.5 measured at $25^{\circ} \mathrm{C}$ is typical for feedwater systems. For example, the $\mathrm{pH}$ of feedwater at Diablo Canyon is about 8.7,

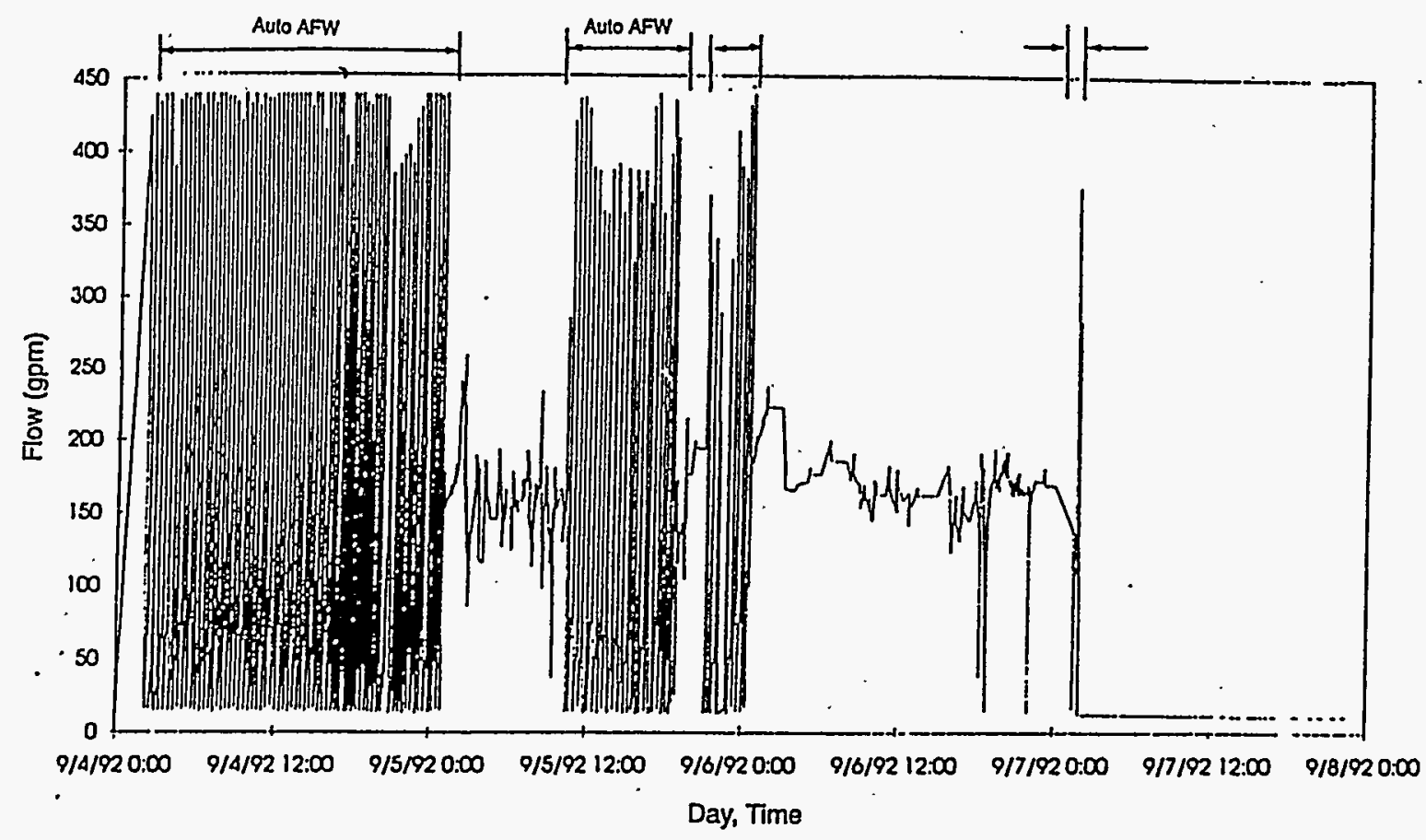

Figure 21. Auxiliary feedwater flow for Sequoyah Unit 2 showing automatic and manual controls (Shvarts et al. 1994). Copyright American Society for Mechanical Engineers; reprinted with permission. 
whereas that at Surry Unit 2 is maintained between 8.8 and 9.2. Feedwater system materials determine the optimum $\mathrm{pH}$ level. Feedwater systems containing copper require a $\mathrm{pH}$ level in the range of 8.8 to 9.2 to prevent excessive copper pickup. Systems with steel materials can tolerate a pH level in the range of 9.3 to 9.6. If ammonia is used for $\mathrm{pH}$ control in the PWR feedwater system, the corresponding optimum $\mathrm{pH}$ level is maintained in the range of 9.3 to 9.6 . If morpholine is used instead of ammonia, the $\mathrm{pH}$ level is maintained at 9.1 to 9.2 and, therefore, morpholine is used in the feedwater systems containing copper. Further discussion on the feedwater water chemistry may be found in Section 7.2.

Flow-accelerated corrosion rates are inversely affected by the amount of dissolved oxygen in the feedwater. Normally, the oxygen level is kept low (typically $4 \mathrm{ppb}$ ) in PWR secondary systems to minimize the degradation of the steam generator tubes. Such a low level of oxygen is harmful to carbon steel piping because the oxygen forms a porous oxide film of magnetite on the inside surface of the piping and the piping becomes susceptible to flow-accelerated corrosion. Tests with neutral water at $100^{\circ} \mathrm{C}\left(212^{\circ} \mathrm{F}\right)$ have shown that the flow-accelerated corrosion rates of carbon steel are high when the water contains less than 20 ppb oxygen, but decrease rapidly with the addition of more oxygen. Higher oxygen levels lead to the formation of a stronger, less soluble iron oxide (hematite), capable of reducing the flowaccelerated corrosion rate by a factor of 3 to 10 .

Although low dissolved oxygen levels in the feedwater accelerate flow-accelerated corrosion damage, as discussed in the previous paragraph, low oxygen levels inhibit corrosion-fatigue provided that such levels are maintained at all times. For example, at some plants the average dissolved oxygen content is quite low in the main feedwater but high in the auxiliary feedwater, and, therefore, the oxygen levels are not low during all operating modes. Copper oxides are present in the feedwater at plants with copper in the feedwater system. These oxides, in addition to dissolved oxygen, also act as an oxidizing agent. Poor control of feedwater chemistry (particularly the oxygen content and possibly copper in the feedwater system) was identified as a root cause for cracking in the nozzle bore, knuckle region, and girth welds at two plants (Westinghouse 1990, Bamford et al. 1992). 


\section{THE SAFETY SIGNIFICANCE OF FEEDWATER LINE RUPTURE}

Main feedwater line rupture is a design basis accident; its consequences include a potential for core damage. The rupture reduces the ability to remove heat generated by the core from the reactor coolant system. In addition, the resulting loss of feedwater would activate and challenge safetyrelated systems to cool the reactor core. A consequent transient-induced steam generator tube rupture could result in the release of significant amounts of radioactive material into the environment, bypassing the containment. Failure of high-energy piping, such as the main feedwater piping, can also result in complex challenges to the plant operating staff because of potential interactions of the high-energy steam and water with other systems, such as the electrical distribution, fire protection, or security systems. Catastrophic failure of any high-energy piping can present a safety problem for plant personnel (USNRC 1989).

Thermal fatigue and flow-accelerated corrosion have damaged PWR feedwater piping during operation. Thermal fatigue has caused throughwall cracking, but no ruptures of cracked pipes have been reported. However, a cracked feedwater pipe could rupture if subjected to seismic or water hammer loads. (Water hammer is expected to be less likely to occur because, as discussed in Section 9, all the U.S. PWR plants have revised and modified the feedwater system design and operation to limit occurrence of steam generator water hammer events.) The USNRC has not accepted the leak-before-break concept for PWR feedwater lines.

Flow-accelerated corrosion has caused significant wall-thinning of main feedwater piping, and in a few cases has resulted in rupture. Wall-thinning has often been found at unexpected sites. Factors affecting flow-accelerated corrosion have been better understood in the last decade. Computer codes have been developed to identify sites susceptible to significant wall thinning and to estimate the rate of wall thinning (see Section 7). Enhanced inspection methods are also being de- veloped to detect and size wall thinning (see Section 8). However, flow-accelerated corrosion can lead to rupture if the associated wall thinning is not detected and repaired or replaced in a timely manner.

A major feedwater line rupture can prevent the addition of sufficient feedwater to the steam generators to maintain secondary coolant inventory in the steam generators. If the break occurs upstream of the first check valve from the steam generator (see Figure 1), it would be similar to an accident caused by a loss of normal feedwater. If the reactor is not tripped during this accident and the auxiliary feedwater is not available, more drastic measures by the operator would be required to prevent core damage.

If the break occurs between the steam generator and the first check valve on the feedwater piping, secondary coolant from the steam generator can be discharged through the break. Also, a break at this location would preclude the subsequent addition of auxiliary feedwater to the faulted steam generator. The consequences of this accident depend on the size and location of the break and the plant operating conditions at the time. The break could either cause a cooldown or a heatup of the reactor coolant system. The cooldown would result from an excessive energy discharge through the break, similar to that which takes place during a postulated main steam line break (Diablo Canyon FSAR).

A postulated break between the steam generator and the check valve could reduce the ability to remove heat from the reactor coolant system and result in the heatup of the reactor coolant system, for three reasons:

(a) The main feedwater line rupture would reduce the feedwater flow to the steam generators. Because feedwater is subcooled, its loss could raise the reactor coolant temperature and pressure prior to reactor trip. 
(b) The coolant in the faulted steam generator may be discharged through the break, and this would not be available for decay heat removal after reactor trip.

(c) The break may be large enough to prevent the addition of any main feedwater after reactor trip.

However, the supply of auxiliary feedwater to the unaffected steam generators must be adequate to remove decay heat and prevent over pressurizing the reactor coolant system. Otherwise, more drastic measures by the operator would be required to prevent core damage.

A faulted steam generator will rapidly depressurize during a main feedwater line break between the steam generator and the first check valve. As a result, the differential pressure across the faulted steam generator tubes will increase, and multiple tube ruptures might occur, especially if the steam generator tubes have a large number of incipient or undetected cracks (USNRC 1988c). Subsequent pressurization of the primary system would increase the leakage rate. If the first check valve is outside the containment and the break is between the containment wall and the check valve, tube leakage would cause release of radioactive products through the break into the environment. In addition, during the accident, the water from the refueling water storage tank is injected into the reactor coolant system through the safety injection system. This water leaks to the faulted steam generator and is then released through the break to the environment. The safety concern is that, in an unlikely event, the refueling water storage tank could be drained before the shutdown cooling mode is achieved, eventually causing core damage. 


\section{FIELD EXPERIENCE RELATED TO CRACKING AND WALL THINNING OF FEEDWATER NOZZLES, PIPING, AND FEEDRINGS}

Feedwater nozzle cracks were first discovered at the D. C. Cook Unit 2 plant in 1979. (An earlier crack in the pipe-to-nozzle weld at Diablo Canyon Unit 1 was thought to have been the result of inadequate welding procedures.) As a result, the USNRC issued Bulletin 79-13. Further inspections revealed instances of cracking in a number of other plants, mainly of Westinghouse design, but a few were of Combustion Engineering design. The cause of the cracking was determined to be thermal fatigue, possibly corrosion assisted, and the root cause was generally attributed to thermal stratification of the coolant in the nozzle. The inspections identified in the Bulletin were completed and the USNRC licensees performed appropriate repairs and established other corrective actions during 1979 through about 1983. Subsequently, at least eight plants experienced feedwater nozzle cracking in the 1983 through 1991 time frame. Based on the responses from the USNRC licensees implementing the actions recommended in Bulletin 79-13, which included augmented inspections at some plants, Bulletin 79-13 was closed in 1991 (Foley, Dean, and Hennick 1991).

The basis of the Bulletin closure was that the feedwater nozzle cracking problem was being adequately managed. However, after the Bulletin was closed in 1991, feedwater nozzle cracking was detected in at least 12 plants during 1992 and 1993, including one through-wall crack. Thus, the number of feedwater nozzle cracking events increased during 1992 and 1993 compared to the 1983-1991 time period; there were about six cracking events per year during 1992 and 1993 compared to one event per year during the earlier time period. However, we have not identified additional feedwater nozzle cracking events since 1993. Sections 6.2 and 6.3 present further details about the field experience, including the size and location of the cracks.

Although fatigue cracking from thermal stratification has been found only in the feedwater nozzle area, the presence of thermal stratification has been verified from temperature measurements on the piping wall far upstream of the nozzle but inside the containment, and also in the feedring piping downstream of the nozzle (Bain, Collins, and Testa 1992). The high loads resulting from thermal stratification have bowed pipes and damaged both feedwater piping and feedring supports.

Fatigue is not the only degradation mechanism that has caused damage to the PWR feedwater systems. Flow-accelerated corrosion has caused wall thinning in feedwater lines, feedrings and J-tubes. Also, the feedwater nozzle thermal sleeves have experienced thinning at the leading edge, possibly because of flow-accelerated corrosion.

Water hammer events can fracture piping at areas degraded by fatigue or flow-accelerated corrosion, and have caused through-wall cracks and ruptures of piping, nozzles, and feedrings. Water hammer events have also damaged piping supports.

The objective of this section is to summarize the field experience with degradation in the feedwater nozzle area. Three types of damage are discussed: (a) thermal fatigue cracking with emphasis on the more recent discoveries after the closeout of Bulletin 79-13, (b) wall thinning caused by flowaccelerated corrosion, and (c) steam generator water hammer damage. Section 6.1 summarizes the fatigue cracking field experience during the period from the initial crack discoveries in 1979 to the completion of the inspections required by the Bulletin. Section 6.2 describes the fatigue cracking events after the initial inspections but before the Bulletin closeout, and Section 6.3 presents the field experience after the closeout of the Bulletin. Degradation caused by flowaccelerated corrosion is discussed in Section 6.4, and examples of steam gnerator water hammer damage are included in Section 6.5. 


\subsection{Initial Discoveries of Fatigue Cracking}

This section briefly describes the fatigue cracking in the US plants from 1979 to the early 1980s. These cracks were discovered because of leakage or during subsequent inspections requested in Bulletin 79-13.

The first discovery of feedwater nozzle cracks was in Diablo Canyon Unit 1, a 4-loop PWR of Westinghouse design, during hot functional testing in 1977 (USNRC 1979a). Subsequent investigations with radiographic testing (RT) and ultrasonic testing (UT) equipment revealed a crack approximately $152-\mathrm{mm}$ (6-in.) long, originating in the weld heat-affected zone of the leaking nozzle weld. The cause was ascribed to either corrosion-fatigue or thermal fatigue initiating at small cracks probably induced by welding or post-weld heat treatment. The system was repaired by replacement of the piping weld with one of identical design, commonly referred to as an in-kind replacement, and employing greater controls on the welding, including maintaining the preheat temperature until the post-weld heat treatment.

About 2 years later, coolant leakage was reported at D.C. Cook Unit 2, another 4-loop PWR of Westinghouse design, which had operated for about 1 year (USNRC 1979a). Through-wall circumferential cracks were discovered in the 405-mm (16-in.) diameter feedwater lines in the vicinity of two of the four steam generator feedwater nozzles. The through-wall cracks were in the upper half of the cross section. Subsequent radiographic examinations revealed cracks or crack-like indications in all eight steam generator feedwater inlet lines of both D. C. Cook units. The most severe crack was a through-wall circumferential crack, $90-\mathrm{mm}$ (3.5-in.) long at the outer surface.

The USNRC issued Bulletin 79-13 because of the leakage at D.C. Cook Unit 2 (USNRC 1979a). The Bulletin requested that the USNRC licensees of operating PWRs perform volumetric examinations (radiographic and ultrasonic) of the feedwater piping weld areas, perform visual inspections of the feedwater piping and piping supports inside the containment, review the adequacy of procedures for responding to a feedwater line break, and report the sensitivity of the methods for detecting feedwater leaks within the containment. If cracking was detected, the licensee was to examine all the feedwater piping welds up to the first piping support and at all high stress points of the piping within the containment to determine the extent of the cracking. Revision 1 of the Bulletin was issued to designated applicants for an operating license and asked that they conduct volumetric and visual examinations. Revision 2 of the Bulletin reduced the scope of the examinations based on prior results.

$B \& W$ plants were exempted from the actions requested in the Bulletin because the $B \& W$ design has a separate nozzle for auxiliary feedwater into the steam generator, the feedwater is always preheated above $180^{\circ} \mathrm{C}\left(360^{\circ} \mathrm{F}\right)$ for all modes of operation, and the feedwater velocity [greater than $3 \mathrm{~m} / \mathrm{s}(10 \mathrm{fps})]$ is sufficient to keep steam from backing up into the feedwater line from the steam generator. The $3-\mathrm{m} / \mathrm{s}$ (10-fps) velocity represents a flow rate of greater than $15,000 \mathrm{l} / \mathrm{min}(4,000$ gpm). Some Combustion Engineering plants, for example, Ft. Calhoun and Calvert Cliffs Units 1 and 2, as well as later vintage Westinghouse plants, also have separate auxiliary feedwater nozzles.

As a result of the examinations conducted in response to Bulletin 79-13, cracks were discovered in the feedwater nozzle areas of 18 PWRs, sixteen designed by Westinghouse (including Salem Unit 1), and two by Combustion Engineering. Only the cracks initially found in the two D. C. Cook Unit 2 feedwater nozzles were through-wall. Although there were no cracks found in the Yankee Rowe nozzles, the welds were deemed unacceptable by present-day codes, and all unacceptable welds were either repaired or replaced. No cracking was found in 17 other plants (including Haddam Neck). Thirteen plants were designated applicants for operating licenses (including Diablo Canyon Units 1 and 2, San Onofre Units 2 and 3, and Sequoyaiı Units 1 and 2), and no examinations were identified for five $B \& W$ plants. The bulletin was closed for the 13 plants that were designated 
applicants for operating licenses on the basis of having completed or committed to complete the inspections required by the bulletin (Foley, Dean, and Hennick 1991). Therefore, the required inspections must have been completed at 11 of these plants, which have been in commercial operation for more than 10 years. The required inspection must have been partially completed at Watts Bar 1, which went in commercial operation in May 1996, whereas Watts Bar 2, the remaining designated applicant for an operating license, is still at the construction stage.
Typical cracks were transgranular, oriented in the circumferential direction and initiated at the inside surface, as shown in Figure 22. In this figure, the primary crack (deepest crack) is a circumferential crack that has grown in the radial direction. There are several shallow secondary cracks adjacent to the primary crack. Whereas the maximum crack depth in some units was less than $2.5 \mathrm{~mm}(0.100$ in), several cracks had propagated 6 to $19 \mathrm{~mm}$ ( 0.250 to 0.750 in.) through the wall. Most of the cracking occurred in the counterbore region of the base metal (see Section 3.3), primarily at the re-

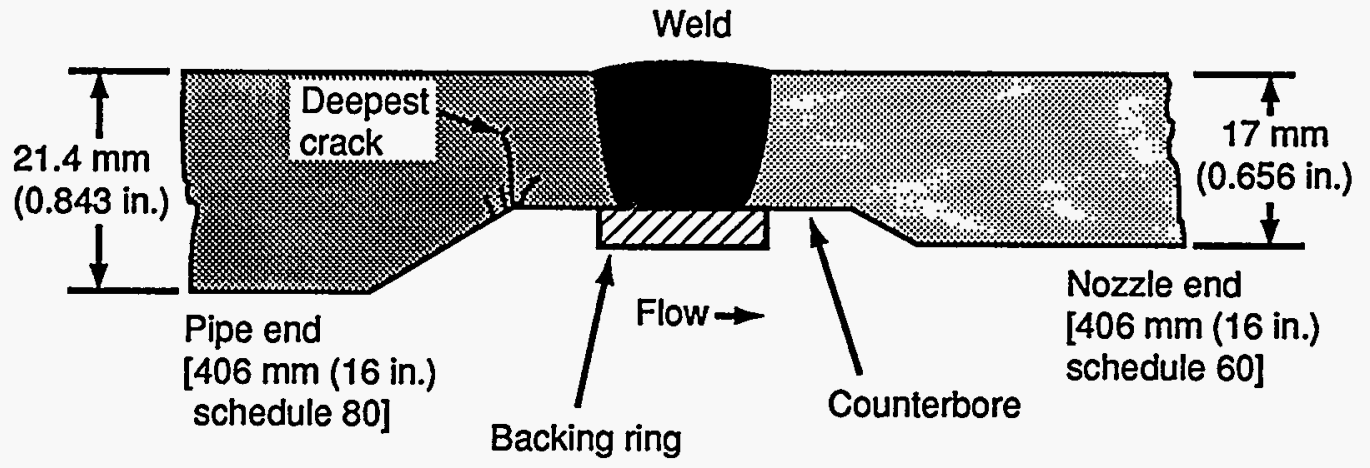

(a) Crack profile in degraded feedwater piping.

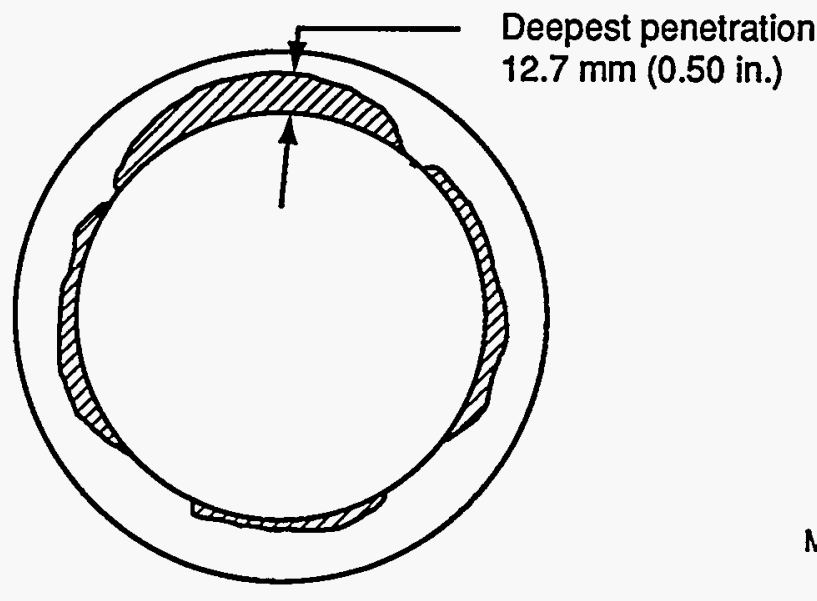

M96 0336

(b) Crack location in the D.C. Cook nozzle (USNRC 1980).

Figure 22. Typical fatigue crack orientation at feedwater nozzle counterbore. 
entrant corner of the counterbore at the upstream end, not in the weld or heat-affected-zone. However, the major cracks in a few units initiated away from the counterbore. For example, in San Onofre Unit 1 (a 3-loop Westinghouse plant), the major crack [2.54-mm (0.1-in.) deep] initiated in the weld whereas in Palisades (a Combustion Engineering plant), the major crack [4.3-mm $(0.17$-in.) deep] initiated near the weld in the heataffected zone (Consumers Power 1979). At Kewaunee (a 2-loop Westinghouse plant) a crack initiated in the piping at the weld interface. Examinations of the weld areas found tool marks and machining grooves in the counterbore region. The through-wall cracks occurred at the top of the pipe, though many other cracks were found at the 3 and 9 o'clock positions. The fracture surfaces of the through-wall cracks showed striations, typical of fatigue crack growth, and the presence of corrosion products. Table 3 summarizes the extent of damage at the 18 PWR plants where cracking was discovered during the inspections performed in response to the Bulletin.

The cracking was attributed primarily to thermal fatigue caused by thermal stratification and striping in the nozzle region and concentrated at the stress raiser at the counterbore. Corrosion fatigue apparently played a secondary role in the cracking. Some of the cracks initiated at pits on the inside surface, and corrosion products have been found on crack surfaces. Although oxygen is thought to be a factor in accelerating the fatigue, it is not considered to be the primary factor.

The following conclusions are drawn from a metallographic study of cracked feedwater nozzle samples from nine PWRs (Goldberg, Streit, and Scott 1980):

- The major cracks initiated along the discontinuous section change at the bottom of the counterbore slope and/or other geometric discontinuities, and along weld surfaces.

- The cracks extended circumferentially along the inside diameter and propagated relatively straight in a direction that closely bisected the angle formed by the intersection of the two surfaces of the discontinuity.

- The piping from some plants contained many shallow cracks or corrosion spikes less than $0.25-\mathrm{mm}(0.010$-in.) deep. Samples from other plants contained a number of intermediate size cracks 0.25 to $1.0-\mathrm{mm}(0.010$ - to 0.039 -in.) deep, and two plants (Palisades and San Onofre 1) contained a number of cracks greater than 1-mm (0.039-in.) deep. The remaining plants had either no cracks or very few cracks in addition to the major crack.

- The cracking was predominantly transgranular. Some minor branching was evident in a few plants.

- Corrosion products, mainly $\mathrm{Fe}_{3} \mathrm{O}_{4}$ and $\mathrm{Fe}_{2} \mathrm{O}_{3}$, were present on all crack surfaces except on those from the deep D. C. Cook crack. Corrosion pitting, especially at the root of machining grooves, probably accelerated the initiation of cracking but was a minor overall contributor.

Test instrumentation consisting of strain gages, accelerometers, thermocouples, pressure transducers, and displacement transducers were temporarily installed on the feedwater nozzles and adjacent piping of several plants where cracking had already occurred (including two nozzles of D. C. Cook Unit 2), to monitor for the stressors causing fatigue. Westinghouse Electric Corporation also carried out laboratory tests (Hu, Houtman, and White 1981), finite element analysis (Thurman, Mahlab, and Boylstein 1981), and crack growth analyses (Bamford, Thurman, and Mahlab 1981) to verify the cause and consequences of the cracking. All the resulting information tended to confirm that the root cause of the cracking was fatigue induced mainly by thermal stratification, enhanced by the weld counterbore and possibly environmental effects. Augmented inspections were implemented at several plants as part of the refueling outage inservice inspection (ISI) program. 
Table 3. PWR feedwater piping cracking during 1979-1980 (USNRC 1980). $(1 \mathrm{in} .=25.4 \mathrm{~mm})$.

\begin{tabular}{|c|c|c|c|c|c|}
\hline Plant & $\begin{array}{l}\text { Vendor/steam } \\
\text { generator model }\end{array}$ & $\begin{array}{l}\text { Maximum } \\
\text { depth } \\
\text { (in.) }\end{array}$ & $\begin{array}{l}\text { Circumferential } \\
\text { Lecation }\end{array}$ & $\begin{array}{c}\text { Lines } \\
\text { cracked }^{\mathbf{b}}\end{array}$ & Comments \\
\hline Beaver Valley 1 & $\underline{\mathrm{W}}$ & 0.400 & 9 o'cluck & 3 of 3 & $\mathrm{~N}^{c}$ \\
\hline D.C. Cook 1,2 & $\underline{\mathrm{w}}$ & $\begin{array}{l}\text { Trough- } \\
\text { wall }\end{array}$ & Top & 8 of 8 & $\begin{array}{l}\text { Through-wall } \\
\text { cracks in two of } \\
\text { the four Unit } 2 \\
\text { lines }\end{array}$ \\
\hline Ginna & $\underline{\mathrm{w}}$ & 0.107 & 8:30 o'clock & 2 of 2 & $N$ \\
\hline Kewaunee & $\underline{\mathrm{w}}$ & 0.050 & 7 o'clock & 2 of 2 & $\begin{array}{l}\text { 3-in. auxiliary } \\
\text { feed near SG } \\
\text { inlet }\end{array}$ \\
\hline Millstone 2 & CE & 0.250 & 12 o'clock & 2 of 2 & $\mathbf{N}$ \\
\hline Palisades & CE & 0.170 & $3 \& 9$ o'clock & 2 of 2 & $\begin{array}{l}\text { Cracks also } \\
\text { found at weld in } \\
\text { vicinity of } \\
\text { horizontal pipe }\end{array}$ \\
\hline Point Beach 1,2 & $\underline{\mathrm{w}}$ & 0.047 & 3 o'clock & 2 of 4 & $\begin{array}{l}\text { 3-in. auxiliary } \\
\text { feed near SG } \\
\text { inlet }\end{array}$ \\
\hline H. B. Robinson 2 & $\underline{\mathbf{W}}$ & 0.750 & 9 o'clock & 3 of 3 & $\begin{array}{l}\text { Shallow cracking } \\
\text { of nozzle under } \\
\text { thermal sleeve }\end{array}$ \\
\hline Salem 1 & $\underline{\mathrm{W}}$ & 0.235 & $N$ & 4 of 4 & $\mathrm{~N}$ \\
\hline San Onofre 1 & $\underline{\mathrm{W}}$ & 0.100 & $\begin{array}{l}\text { Lower half of } \\
\text { reducer }\end{array}$ & 3 of 3 & $\begin{array}{l}\text { Multiple- } \\
\text { branched cracks, } \\
\text { fatigue }\end{array}$ \\
\hline Surry 1,2 & $\underline{\mathrm{w}}$ & 0.080 & $2 \& 5 o^{\prime}$ clock & 6 of 6 & $N$ \\
\hline Turkey Point 3,4 & $\underline{\mathrm{W}}$ & $\mathrm{N}$ & $\mathbf{N}$ & 6 of 6 & $\mathbf{N}$ \\
\hline Zion 1,2 & $\underline{\mathrm{W}}$ & 0.088 & $\mathbf{N}$ & $\mathbf{N}$ & $\mathrm{N}$ \\
\hline
\end{tabular}

a. The typical thickness of a feedwater line pipe wall is approximately 13 to $25 \mathrm{~mm}$ ( 0.5 to $1 \mathrm{in}$.).

b. Number of total feedwater lines into steam generators that were found to be cracked. For example, the D.C. Cook plants are 4-loop Westinghouse units, so all eight lines in the two plants were cracked.

c. Additional information was not found. 
Many PWR units experienced lengthy outages in 1979 and 1980 while these inspections and appropriate modifications and repairs were performed. The repairs generally consisted of inkind replacements of the cracked sections. Some of the cracks were sufficiently shallow to simply be ground out. On several units, the sharp discontinuity associated with the counterbore was redesigned with a fillet having a $12.7-\mathrm{mm}$ (0.5-in.) radius, and a 125 root mean square (RMS) surface finish was specified for the transition region. Units such as D. C. Cook installed protective liners, made of carbon steel and approximately $13-\mathrm{mm}(0.5-\mathrm{in}$.) thick, inside the nozzles. Some utilities, such as Callaway and Wolf Creek, have special startup feedwater systems (described in Section 2.1) that supply the heated main feedwater. More complete descriptions of the types of modifications available to mitigate damage are presented in Section 9.1.

\subsection{Crack Discoveries Between Initial Inspections and Bulletin Closeout}

Feedwater nozzle cracking was found in eight PWRs during the time period of 1983 to 1991, several years after the initial inspections performed in response to Bulletin 79-13. These included cracks in the nozzle areas of two plants (Beaver Valley 1 and Turkey Point 4) that had experienced cracking earlier and for which repair or replacement had been performed. Six of these plants were of Westinghouse design; two were of Combustion Engineering design. The events are summarized in Table 4, and the repair and replacement activities that followed in response to these cracking events are summarized in Table 5. Most of these incidents of cracking were similar to those discovered in the 1979 round of inspections, but there were two notable exceptions, leakage at Maine Yankee and extensive cracking at Indian Point 2, which are described here.

\subsubsection{Maine Yankee}

The Maine Yankee cracking resulted in a leak when a water hammer caused fracture of an already existing fatigue crack (Garrity 1983). J-tubes had not been installed on the steam generators at this time. The nozzle is connected to a safe end, which connects to a 20-degree bend. The bend is connected to a $0.7-\mathrm{m}$ (2-ft) length of straight pipe, which connects to a 90-degree elbow that turns downward (Stoller 1983). The crack was located at the bottom of the pipe near the first weld upstream of the nozzle. The crack was propagating from the inside surface of the pipe at the reentrant corner of the counterbore. The crack was $0.9-\mathrm{m}$ (35-in.) long on the inside surface and $0.28-\mathrm{m}^{\prime}(11-\mathrm{in}$.) on the outside surface. Examinations revealed that there had probably been a tool mark located at the counterbore that aggravated the stress concentration. Fatigue cracks were found at the same location on the other two feedwater lines, but these cracks did not become through-wall because water hammers did not occur in those lines. All cracks extended from the 11 to 7 o'clock position (240 degrees around the circumference). Sections of pipe were replaced, counterbores were removed in the redesigned pieces, small cracks were ground out, and the repaired welds were inspected by RT and UT to establish a baseline.

\subsubsection{Indian Point Unit 2}

Cracking Incidents in 1989. Extensive thermal fatigue cracking was found in the Indian Point Unit 2, a Westinghouse 4-loop plant, feedwater nozzles during the 1989 inservice inspection. The cracking was found in the feedwater nozzle blend radius or inner radius section (also called knuckle region), steam generator shell inside surface beneath the nozzle, the feedwater nozzle bore region under the thermal sleeve, and in the pipe-to-nozzle weld region as shown in Figure 23 (Westinghouse 1989). The cracking was caused by cold feedwater leaking past the thermal sleeve, abetted by environmental effects resulting from poor water chemistry control (high dissolved oxygen). The leak path was through the small 
Table 4. PWR feedwater nozzle cracking 1983 to present $^{\mathrm{a}}$ ( 1 in. $=25.4 \mathrm{~mm}$ ).

\begin{tabular}{|c|c|c|c|c|c|c|}
\hline Plant & Date & $\begin{array}{l}\text { Vendor/steam gen- } \\
\text { erator model }\end{array}$ & $\begin{array}{l}\text { Maximum } \\
\text { depth }\end{array}$ & $\begin{array}{l}\text { Circumferential } \\
\text { location/extent }\end{array}$ & $\begin{array}{l}\text { Lines } \\
\text { cracked }\end{array}$ & Comments \\
\hline \multicolumn{7}{|l|}{1983 to 1991} \\
\hline St. Lucie $1^{2}$ & 1983 & $\mathrm{CE}$ & $\mathrm{N}^{\mathrm{s}}$ & $\mathrm{N}$ & $2 / 2$ & safe-end base metal \\
\hline Maine Yankee & 1983 & $\mathrm{CE}$ & through-wall & $\begin{array}{l}\text { leak at bottom of } \\
\text { pipe; cracking } 11 \text { to } \\
7 \text { o'clock }\end{array}$ & $3 / 3$ & $\begin{array}{l}\text { existing crack propagated by } \\
\text { water hammer; cracking only in } \\
\text { pipe side of weld }\end{array}$ \\
\hline Beaver Valley $2^{\prime}$ & $\begin{array}{l}1983 \\
1985\end{array}$ & $\underline{w} / 51 \mathrm{M}$ & $\mathbf{N}$ & $\mathbf{N}$ & $\mathbf{N}$ & $\mathbf{N}$ \\
\hline Turkey Point $4^{4}$ & 1984 & $\underline{W} / 44 \mathrm{~F}$ & $\mathbf{N}$ & $\begin{array}{l}270^{\circ}(\mathrm{A}), 180^{\circ}(\mathrm{C}) \\
\text { around }\end{array}$ & $2 / 3$ & $\begin{array}{l}\text { base metal in pipe-to-nozzle } \\
\text { weld region }\end{array}$ \\
\hline Farley $1^{5}$ & 1984 & $\underline{w} / 51$ & $\begin{array}{l}7-37 \% \\
\text { through- wall }\end{array}$ & $\begin{array}{l}11-1,7-9,4-5(B \\
\text { only) o'clock }\end{array}$ & $3 / 3$ & $\begin{array}{l}\text { base metal in pipe-to-nozzle } \\
\text { weld region }\end{array}$ \\
\hline Trojan 6 & 1987 & $\underline{W} / 51 A$ & 0.533 in. & $4,7,9,12$ o'clock & $3 / 4$ & $\begin{array}{l}\text { base metal in pipe-to-nozzle } \\
\text { weld region }\end{array}$ \\
\hline Beaver Valley $1^{7}$ & 1987 & $\underline{W} / 51$ & $\mathbf{N}$ & $\mathrm{N}$ & $3 / 3$ & pipe-to-nozzle weld region \\
\hline Indian Point 2' & 1989 & $\underline{W} / 44 \mathrm{~F}$ & $\begin{array}{l}0.347 \text { in. } \\
\text { (bore); } 0.388 \\
\text { in. (weld) }\end{array}$ & bottom $120^{\circ}$ & $2 / 4$ & $\begin{array}{l}\text { pipe-to-nozzle weld region; up- } \\
\text { stream piping; nozzle inner bore }\end{array}$ \\
\hline \multicolumn{7}{|l|}{1991 to nresent } \\
\hline Beaver Valley $1^{!}$ & 1992 & $\underline{W} / 51$ & $\mathbf{N}$ & $\mathbf{N}$ & $\mathbf{N}$ & $\mathbf{N}$ \\
\hline Sequoyah $1^{9}$ & $\begin{array}{l}1992 \\
1993\end{array}$ & $\underline{w} / 51$ & through-wall & 3 and 9 o'clock & $3 / 4$ & $\begin{array}{l}\text { leak in one line; transition piece; } \\
\text { AFW auto/manual }\end{array}$ \\
\hline Sequoyah $2^{9}$ & $\begin{array}{l}1992 \\
1993\end{array}$ & $\underline{\mathrm{W}} / 51$ & $\begin{array}{l}60 \% \text { through- } \\
\text { wall }\end{array}$ & $\begin{array}{l}\text { most at } 3 \text { and } 9 \\
\text { o'clock (slightly ro- } \\
\text { tated), one at top }\end{array}$ & $2 / 4$ & $\begin{array}{l}\text { transition piece; AFW } \\
\text { auto/manual }\end{array}$ \\
\hline Salem $1^{10}$ & 1992 & $\underline{w} / 51$ & $\mathrm{~N}$ & $\mathbf{N}$ & $4 / 4$ & $\begin{array}{l}\text { nozzle-to-expander and } \\
\text { expander-to-elbow weld areas }\end{array}$ \\
\hline Diablo Canyon 1" & 1992 & $\underline{w} / 51$ & 0.06 & $\begin{array}{l}360^{\circ} \text { around } \\
\text { circumference }\end{array}$ & $4 / 4$ & $\begin{array}{l}\text { base metal in pipe-to-nozzle } \\
\text { weld region }\end{array}$ \\
\hline Prairic Island $1 \& 2^{1}$ & 1992 & $\underline{W} / 51$ & $\mathrm{~N}$ & $N$ & $\mathbf{N}$ & $\mathrm{N}$ \\
\hline Haddam Neck ${ }^{12}$ & 1993 & $\underline{w} / 27$ & 0.25 & lower $180^{\circ}$ & $3 / 4$ & $\begin{array}{l}\text { base metal in pipe-to-nozzle } \\
\text { weld region }\end{array}$ \\
\hline Robinson $2^{\prime}$ & 1993 & $\underline{W} / 44 \mathrm{~F}$ & $\mathbf{N}$ & $\mathbf{N}$ & $\mathbf{N}$ & $\mathbf{N}$ \\
\hline Turkey Point $3^{\prime}$ & 1993 & $\underline{W} / 44 \mathrm{~F}$ & $N$ & $\mathbf{N}$ & $\mathrm{N}$ & $N$ \\
\hline San Onofre $3^{13}$ & 1993 & $\mathrm{CE}$ & 0.02 & 3 and 9 o'clock & $2 / 2$ & $\begin{array}{l}\text { AFW on/off prior to 1986; safe } \\
\text { end }\end{array}$ \\
\hline Farley $2^{1}$ & 1993 & $\underline{w} / 51$ & $\mathbf{N}$ & $\mathbf{N}$ & $\mathbf{N}$ & $\mathbf{N}$ \\
\hline
\end{tabular}


FIELD EXPERIENCE

Table 5. Repair/replacement activities 1983 to present.

\begin{tabular}{|c|c|c|c|c|c|}
\hline Plant & Replacement & $\begin{array}{l}\text { Grind/ } \\
\text { weld } \\
\text { repairs }\end{array}$ & $\begin{array}{l}\text { Thermal liner/ } \\
\text { sealing sleeve } \\
\text { installation }\end{array}$ & $\begin{array}{l}\text { Joint design } \\
\text { modification }\end{array}$ & $\begin{array}{l}\text { Thermal } \\
\text { sleeve } \\
\text { replacement }\end{array}$ \\
\hline Beaver Valley $2^{1}$ & - & - & 1985 & - & - \\
\hline St. Lucie $1^{2}$ & 1983 & - & $\cdot$ & - & - \\
\hline Maine Yankee ${ }^{3}$ & 1983 & 1983 & - & $\begin{array}{l}\text { stress raiser } \\
\text { removed }\end{array}$ & - \\
\hline Turkey Point $4^{4}$ & 1984 & - & - & $\begin{array}{l}\text { counterbore } \\
\text { removed }\end{array}$ & - \\
\hline Farley $1^{5}$ & 1984 & - & B loop & - & - \\
\hline Trojan $^{6}$ & 1988 & - & - & $\begin{array}{l}\text { counterbore } \\
\text { redesigned; A } \\
\text { loop only, } \\
\text { counterbore } \\
\text { moved away } \\
\text { from weld }\end{array}$ & $\begin{array}{c}\text { partial } \\
1988\end{array}$ \\
\hline Beaver Valley $1^{7}$ & 1988 & - & 1992 & - & - \\
\hline Indian Point $2^{8}$ & - & 1989 & 1991 & - & - \\
\hline Sequoyah $2^{9}$ & 1992 & - & two loops 1994 & $\begin{array}{l}\text { stress raiser } \\
\text { removed }\end{array}$ & - \\
\hline Salem $1^{10}$ & 1992 & 1992 & planned & -1 & - \\
\hline Diablo Canyon $1^{\text {"l }}$ & 1992 & 1992 & 1994 & - & - \\
\hline Prairie Island 1 and $2^{2}$ & 1992 & - & - & 1992 & - \\
\hline Sequoyah $1^{9}$ & 1992 & - & 1995 & $\begin{array}{l}\text { stress raiser } \\
\text { removed }\end{array}$ & - \\
\hline Haddam Neck ${ }^{12}$ & 1993 & 1993 & - & - & - \\
\hline Robinson $2^{1}$ & 1993 & - & - & - & - \\
\hline Turkey Point $3^{1}$ & 1993 & - & - & - & - \\
\hline San Onofre $3^{13}$ & - & 1993 & - & - & - \\
\hline
\end{tabular}

1. Westinghouse proprietary Class $2 \mathrm{C}$ handout at Westinghouse/NRC meeting $3 / 21 / 95$

2. USNRC 1983b

3. Garrity 1983

4. Florida Power \& Light 1984

5. USNRC 1984b

6. Cockfield 1988

7. USNRC $1987 \mathrm{~b}$

8. Westinghouse 1989,1990

9. TVA 1992a and b, Coley 1992, Cofie et al. 1994

10. PSE\&G 1992, Stoller $1992 b$

11. PG\&E 1992, Cofie et al. 1994, Thailer et al. 1995

12. McBrearty 1993

13. Mostafa and Ramsey 1994 
gap, typically $0.25-$ to $0.50-\mathrm{mm}(0.010-$ to 0.020 -in.) wide, between the thermal sleeve and the nozzle. Whereas the dissolved oxygen in the feedwater is maintained at a low level during normal operation (it averaged $2 \mathrm{ppb}$ in 1989), cold, oxygenated water was drawn from the condensate storage tank when the plant was in hot standby and shutdown conditions and injected via the auxiliary feedwater system. A 203-mm (8-in.) diameter vent to the atmosphere to release insoluble gas buildup allowed oxygen to enter the condensate storage tank. It is believed that this introduction of oxygen was a major contributor to the cracking. Some plants use a nitrogen blanket in the condensate storage tank to prevent oxygen ingress. Contaminants from condenser inleakage may have aggravated the problem.

Visual examination detected linear indications on the inner radius section of one of the four feedwater nozzles. These indications were located on the lower 120-degree segment of the nozzle. Liquid penetrant examination confirmed these indications and also found additional indications on the two support brackets welded to the nozzle just below the knuckle. Visual and penetrant examination on the other three nozzles revealed linear indications on the inner radius section of one

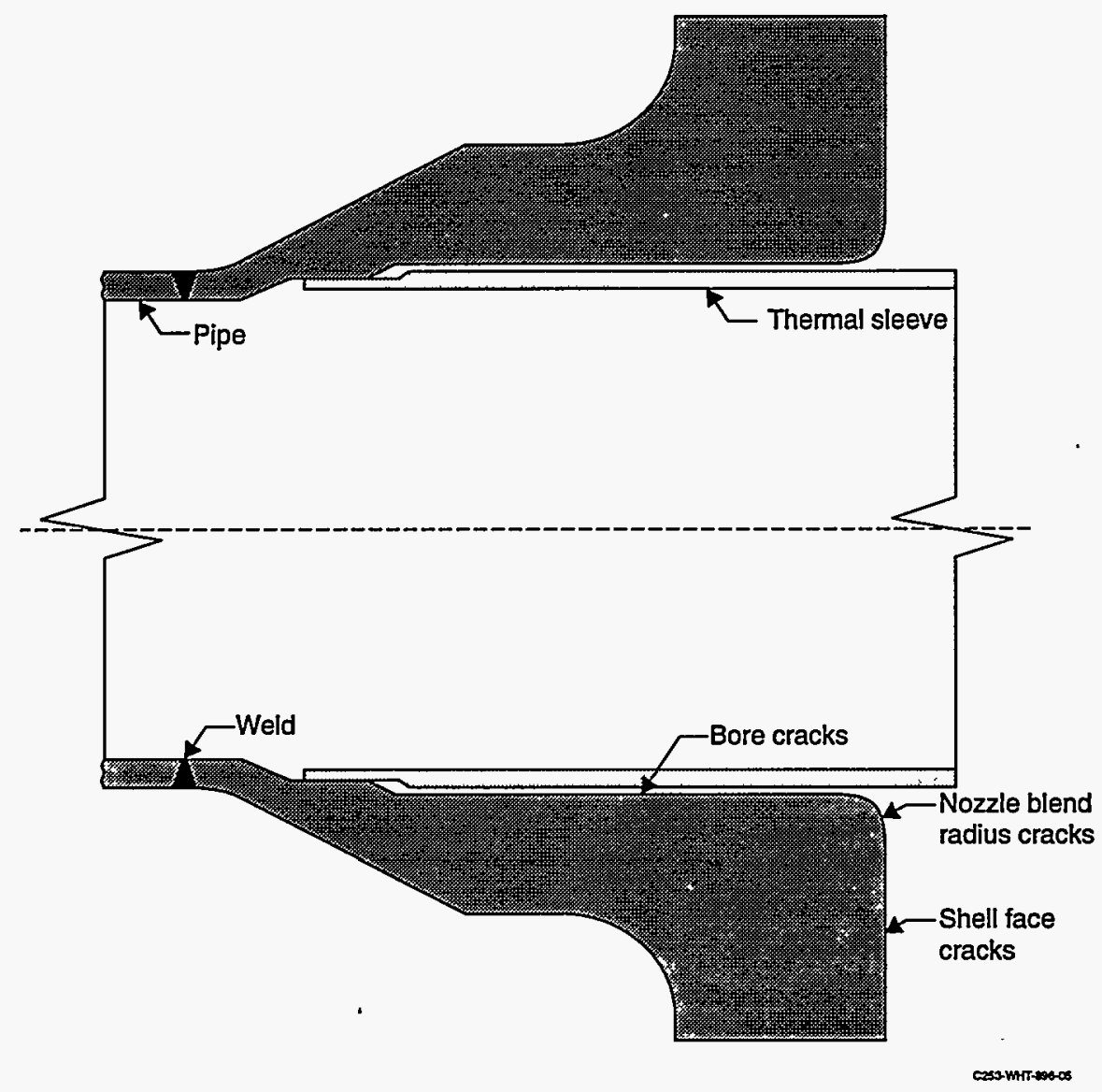

Figure 23. Locations of thermal fatigue cracks in an Indian Point Unit 2 feedwater nozzle and steam generator shell caused by bypass leakage of cold feedwater (Westinghouse 1989). 
nozzle. No indications were found on the other two nozzles. The maximum depth of the indication was less than $5 \mathrm{~mm}(0.2 \mathrm{in}$.$) . All$ indications were removed by grinding.

Fiberscope examinations of the inner and outer surfaces of the thermal sleeves and the inner surface of the nozzle bore over the lower 90 degrees did not reveal any linear indications. Ultrasonic examinations of the lower 180 degrees of all four feedwater nozzle bores and $100 \%$ radiographic examinations of all four feedwater nozzle-to-pipe welds did not reveal any linear indications.

Westinghouse (1989) reported two other examples of feedwater nozzle cracking. In one case, linear indications were found in the nozzle bore near the knuckle region. Cracking was attributed to excess leakage through the gap between the thermal sleeve and the nozzle bore. Excess leakage occurred because of two reasons: (1) cracking of the thermal sleeve caused by a water hammer, and (2) thinning of the leading edge of the thermal sleeve, possibly caused by flow-accelerated corrosion. These indications were removed by grinding. In the second case, the cracking occurred in the knuckle region of an auxiliary feedwater nozzle of a PWR steam generator. The cracking was a result of leakage past the slip fit joint between the nozzle and thermal sleeve. Similar leakage has caused cracking in the knuckle region of several boiling water reactor (BWR) feedwater nozzles.

Cracking Incidents in 1990. Indian Point Unit 2 was shutdown in February 1990 to perform a mid-cycle inspection of all four steam generator feedwater nozzles and other locations that have been determined to be susceptible to cracking based on the 1989 inspections. Visual and magnetic particle inspections of the shell face in the nozzle region, the nozzle inner radius (blend radius), and the support bracket welds beneath the nozzle were performed. Linear indications were found on the nozzle inner radius sections of two steam generators and in the heat-affected zone of the weld between the feedwater nozzle and the steam generator shell (near the support bracket welds) in all four steam generators. All indications were removed by grinding. The maximum grindout depth for the indications was $11 \mathrm{~mm}$ (0.4 in.).

The thermal sleeves were removed from all four steam generators so that visual, liquid penetrant, and ultrasonic examinations of all four nozzle inside surfaces (bores); visual, liquid penetrant, and radiographic examihations of all four nozzle to feedwater piping welds; and visual examination of the thermal sleeves could be performed. UT revealed indications on the nozzle bore ranging in depth from 5 to $9 \mathrm{~mm}(0.198$ to $0.347 \mathrm{in}$.), and indications at the nozzle-to-pipe welds ranging in depth from 5 to $10 \mathrm{~mm}$ ( 0.200 to $0.388 \mathrm{in}$.). Cracking was also found at the 6 o'clock position in the horizontal section of the feedwater piping upstream of the nozzle on all four steam generators. This feedwater pipe cracking is believed to be the result of thermal stratification, which occurs during the cold, low flow auxiliary feedwater injection. These horizontal portions of the feedwater piping were replaced. The auxiliary feedwater tee located outside containment, several feet away from the feedwater nozzle, was also inspected with a fiberscope and no indications were detected.

Metallographic examinations conducted on a nozzle bore sample taken from one steam generator showed multiple axial cracks originating from oxide-covered pits that had linked together. The maximum depth of the crack was approximately 2 $\mathrm{mm}(0.07 \mathrm{in}$.). Copper deposits were also found in the area. The presence of the oxide-covered pits, multiple cracks which initiated from these pits, and the copper contaminants led to the conclusion that the damage mechanism was corrosion fatigue. Fractographic examinations of the fracture faces revealed the presence of a multitude of fine striations, which confirmed that the crack growth was caused by corrosion fatigue. The beach marks on the fracture surface suggested different periods of crack extension, and that the cracking may have occurred over a long time such as during one fuel cycle.

Although the primary cause of the cracking at Indian Point 2 was leakage under the thermal 
sleeve and turbulent mixing of the cold feedwater and the hot steam generator water, poor oxygen control for long periods probably made the situation worse than in other plants. Whereas cracks at the pipe-to-nozzle weld area can be propagated by cyclic thermal stratification, cracks in the nozzle bore under the thermal sleeve are not expected to propagate because the stresses from turbulent mixing rapidly attenuate through the thickness. Since the nozzle is thicker than the weld region, through-wall penetration is unlikely. All cracks and indications were removed by grinding and were repaired by welding (using the temper bead technique) to the design configuration while the thermal sleeves were removed. Future augmented inspections were planned. Longer term mitigation actions include replacing the copper condenser tubes with titanium tubing, conducting corrosion product transport studies, eliminating the bypass flow in the feedwater nozzle, and introducing nitrogen gas cover in the condensate storage tank to prevent any ingress of oxygen into the auxiliary feedwater, and deaerating the auxiliary feedwater.

Cracking Incidents in 1991. A UT examination of a portion of an Indian Point Unit 2 feedwater nozzle bore and knuckle region, and the adjacent feedwater piping was performed from the outside surface during the 1991 refueling outage. The examination detected several reflectors in the bore region but did not reveal any indications in the knuckle region or piping. Subsequent magnetic particle testing of the nozzle bore region after removal of the sleeve did not reveal any cracking. Visual examination of the inside surface of the piping during installation of the thermal sleeve also confirmed the absence of any cracking. Also, radiography of a nozzle-to-pipe weld on one steam generator did not detect any cracking. And, inspection of the feedring support bracket welds with magnetic particle and liquid penetrant techniques did not reveal any cracking.

Liquid penetrant testing of the knuckle region in all four steam generators detected one 13-mm (0.5-in.) long crack located near the 7 o'clock position. The crack was removed by grinding to a depth of $1.25 \mathrm{~mm}(0.05 \mathrm{in}$.). This crack was at a location where one of the original support brackets was welded.

A feedwater nozzle sealing sleeve was installed in 1991 to eliminate the leakage of cold water into the gap between the thermal sleeve and nozzle and thus mitigate the cracking in the nozzle bore and knuckle region. A schematic of the seal ring is shown in Figure 24 (Consolidated Edison 1991). The sealing sleeve is welded to the feedwater nozzle at the feedwater-pipe end, sealing the leakage path of the incoming feedwater. A groove cut at the other end of the sealing sleeve contains a spring loaded sealing ring. The sealing ring compresses against a pad ring welded to the existing thermal sleeve but is free to slide to accommodate differential thermal expansion between the steam generator nozzle and the feedring. Blocks are welded to the thermal sleeve to prevent the sealing sleeve from entering the steam generator if the weld should fail.

\subsection{Fatigue Cracking After Bulletin Closeout}

Cracking events in PWR feedwater nozzles have continued to occur since the 1991 closeout of Bulletin 79-13 and are summarized in Table 4. Feedwater nozzle cracking was detected in at least 12 plants after the Bulletin closure. Eleven of these were Westinghouse design; one was of Combustion Engineering design. All of the Westinghouse steam generators with feedwater nozzle cracking were Model 51 or earlier models. Later models (D2 through D5 and E) have feedwater preheaters and have separate auxiliary feedwater nozzles. A few instances of nozzle cracking have occurred in non-U.S. PWR plants as well.

This section describes cracking in the feedwater nozzle areas of several plants since 1991, beginning with Sequoyah Units 1 and 2, where a leak occurred in one nozzle in 1992. In response to cracking and leakage at Sequoyah, inspections conducted at Salem Units 1 and 2 shortly thereafter revealed cracking in Unit 1 nozzles. Later that year, cracking was discovered at Diablo Canyon 


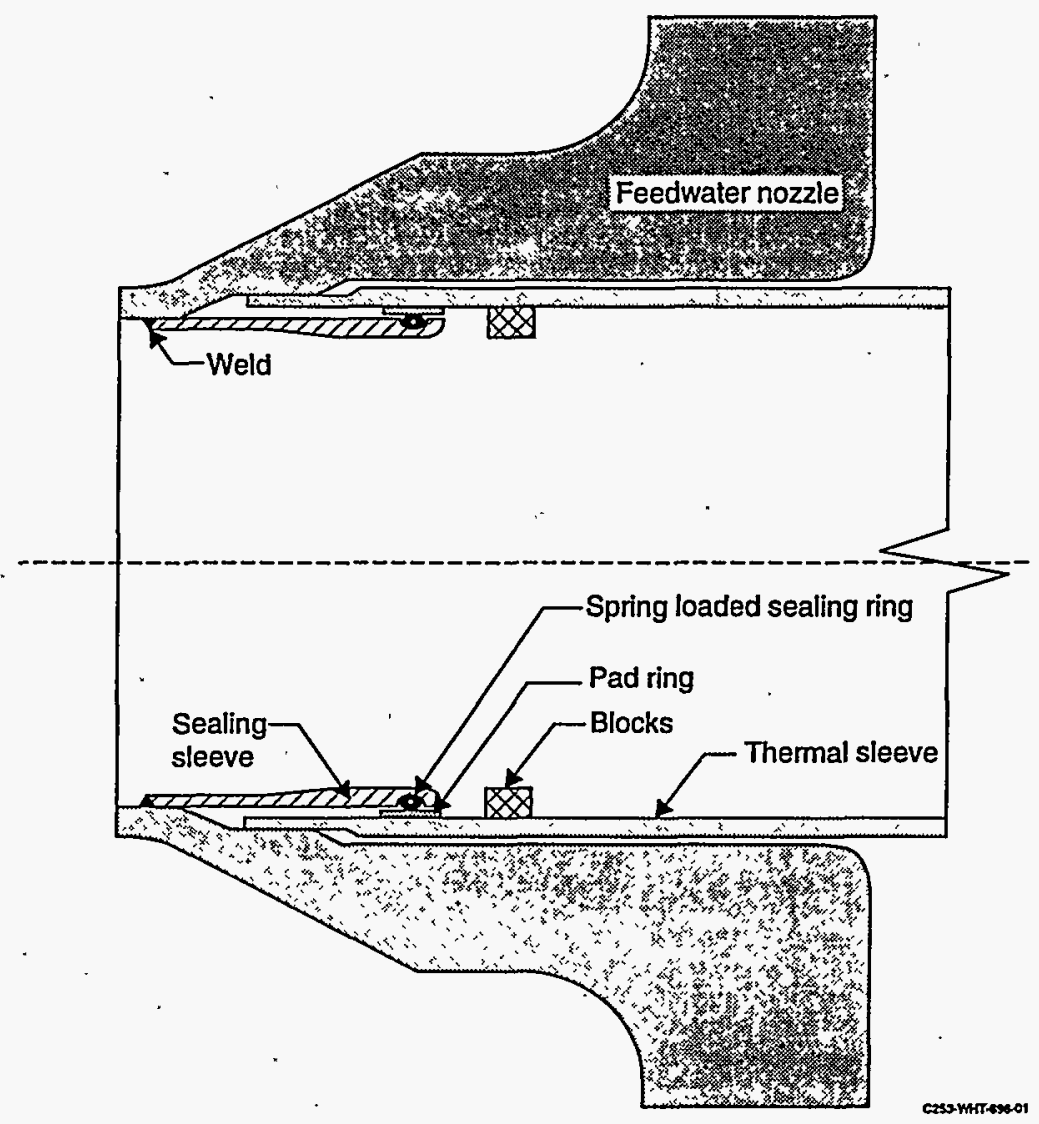

Figure 24. Indian Point Unit 2 feedwater nozzle sealing sleeve installed to prevent bypass leakage of cold feedwater (Consolidated Edison 1991).

Units 1 and 2. Based on these cracking incidents at Sequoyah and Diablo Canyon, the NRC issued Information Notice 93-20 (USNRC 1993) for Westinghouse and Combustion Engineering plants. Cracking was also discovered at the Haddam Neck and San Onofre Unit 3 plants. This section describes the cracking experience at these plants and at other US and non-US plants. The repair and replacement activities that followed in response to these cracking events are summarized in Table 5.

\subsubsection{Sequoyah Units 1 and 2}

Sequoyah Units 1 and 2 (4-loop Westinghouse PWRs) experienced fatigue cracking in early 1992 in the transition pieces connecting the feedwater nozzles to the feedwater piping. Figure 16 shows the construction drawing of the transition pieces, which are $38-\mathrm{mm}$ (1.5-in.) wide, joining the steam generator nozzles and the feedwater piping. These transition pieces are made of the same material (SA-508 Class 2) as the nozzles (Wilson 1992, TVA 1973). The thinner end of each transition piece was field welded to each nozzle. The inside surface was counterbored in this region, resulting in a reentrant corner on either side of the weld. A weld preparation area of base metal beneath the weld on the inside surface is shown in Figure 16. However, in Unit 1, Loop 3, the nozzle-totransition piece weld penetrated through the base 
metal, leaving a reentrant corner with a larger angle and, therefore, a larger stress concentration than that shown on the construction drawing (see Figure 18). This is the general area of major cracking. A larger field weld joined the thicker end of the transition piece and the pipe; no cracking has been experienced at the weld, probably because of a lower stress concentration factor, but there are some cracks at the nearby geometric discontinuities.
The auxiliary feedwater piping at the Sequoyah plants connects to the main feedwater piping inside the containments on Loops 2 and 3 at a vertical rise of the piping upstream of the elbow at the steam generator feedwater nozzle, as shown in Figure 25, but outside the containments on loops 1 and 4 . Each connection consists of an expander [102 to $152 \mathrm{~mm}$ (4 to $6 \mathrm{in}$.)] and a tee fitting [ $405 \times 406 \mathrm{x}$ $152 \mathrm{~mm}(16 \times 16 \times 6 \mathrm{in}$.)] containing a thermal sleeve; these details are not shown in Figure 25.

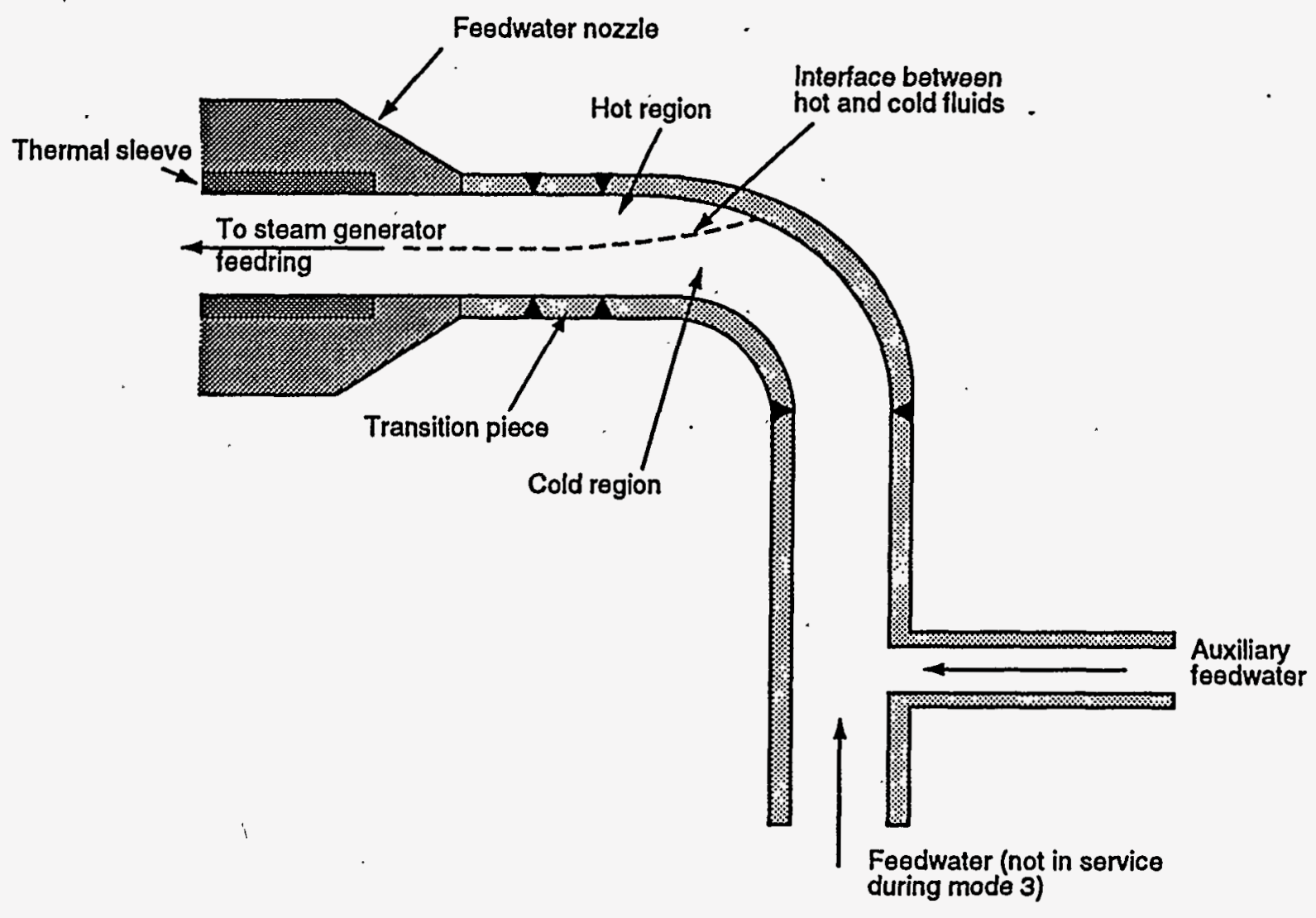

$M 960308$

Figure 25. Stratified flows during operation of auxiliary feedwater system (TVA 1992a). 
The following is a brief history of the operations and inservice inspections at the two units, a summary of the cracking discovered in 1992, results of metallographic examinations of the cracks, results of the root cause analysis (including a discussion of the plant operation that affects feedwater nozzle cracking), a summary of the 1993 cracking, and repair and mitigation efforts that have been undertaken at Sequoyah.

Past History. The construction radiographic examinations of the feedwater nozzles were completed in 1979. Full-power licenses for the two units were issued in 1980 and 1981 respectively, and normal operation began in mid-1981 for Unit 1 and mid-1982 for Unit 2. Nozzle inspections were performed in accordance with Bulletin 79-13 requirements at the first refueling outages on Unit 1 (1982) and Unit 2 (1983). Augmented examinations initiated in 1983 included UT of the feedwater nozzle and the adjacent piping of one loop per refueling outage. The scope of the augmented ultrasonic examinations was expanded in 1988 to include four loops per refueling outage. Several indications were recorded at the crack locations but were misinterpreted as being caused by geometry; later, cracks were discovered at the locations of these indications. The first unmistakable indication of cracking was when leakage occurred at Unit 1 in 1992.

The feedwater chemistry during operation was as follows: (a) oxygen was low, typically less than $100 \mathrm{ppb}$, but copper oxides present in the corrosion products may contribute to corrosion fatigue; (b) the secondary water included hydrazine, 2 to 3 ppm of ethanolamine, and 5 to $100 \mathrm{ppm}$ of boric acid; and (c) the room temperature $\left(25^{\circ} \mathrm{C}\right) \mathrm{pH}$ of the feedwater was in the range of 8.5 to 9.2 .

Cracking Incidents in 1992. In March 1992, with Unit 1 in Mode 3 (hot standby) conditions, a high level alarm for the containment sump went off. Personnel performing inspections in the lower ice condenser bays observed water streaming from the area of Steam Generator 3. The plant was cooled down to Mode 5, and an investigation of the leak was begun. After removal of the insulation, visual inspections revealed a through-wall circumferential crack in the feedwater nozzle-to-transition piece weld region. The crack was on the transition piece side of the weld, as shown in Figure 26. Although the crack was estimated to be $25 \mathrm{~mm}$ ( 1 in.) in length on the outside diameter by visual inspection, radiography revealed that the crack was 51-mm (2-in.) long on the outside diameter and 178-mm (7-in.) long on the inside diameter.

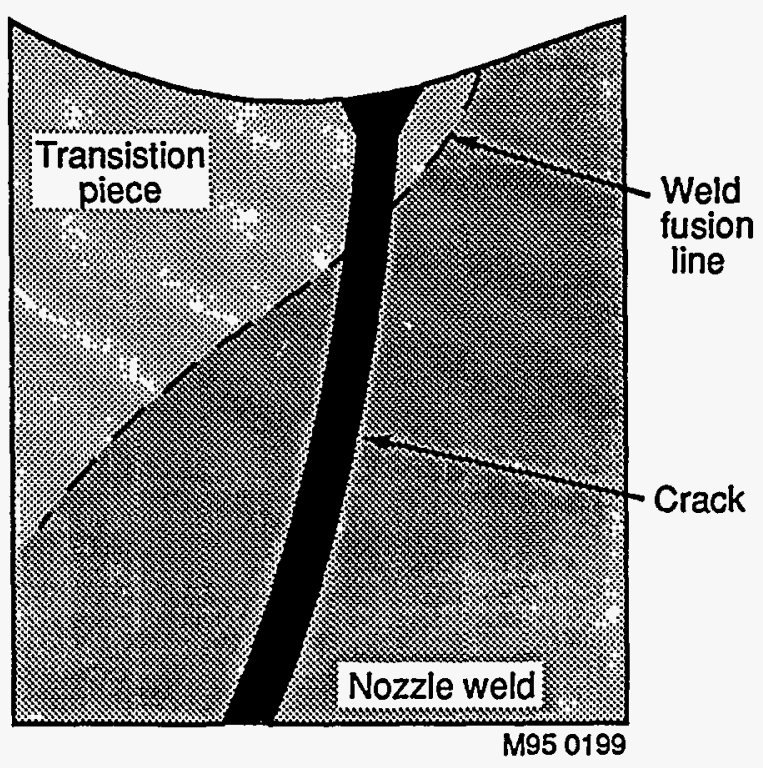

Figure 26. Through-wall crack in the feedwater nozzle weld at Sequoyah Unit 1 (TVA 1992b).

Radiographic examinations (Iridium 192 source with Type 1 film) of all eight nozzles at the two units showed that five of these nozzles had significant cracking (USNRC 1993). The results are summarized in Table 6 (TVA 1992a). All but one of the cracks were located on the two sides of the pipe cross section at about the 90- and 270degree ( 3 and 9 o'clock) locations. The crack on Steam Generator 1 of Unit 2 was located near the top (0-degree or 12 o'clock location). Most of the major cracks were about 127 to $178 \mathrm{~mm}$ (5 to 7 in.) in length and located on the transition piece side of the weld. However, two of the major cracks were located on the nozzle side of the weld. The destructive examination results, discussed in the next section, indicated that the cracking was caused by fatigue. 
Table 6. Results of Sequoyah radiographic inspection (TVA 1992a) $)^{1}(1 \mathrm{in} .=25.4 \mathrm{~mm}$ ).

\begin{tabular}{|c|c|c|c|c|c|c|}
\hline Unit & SG & $\begin{array}{l}\text { Cracking in } \\
\text { transition-to- } \\
\text { elbow weld }\end{array}$ & $\begin{array}{l}\text { Cracking in } \\
\text { nozzle-to- } \\
\text { transition weld }\end{array}$ & $\begin{array}{l}\text { Approximate } \\
\text { location }\end{array}$ & Length & Comments \\
\hline \multirow[t]{7}{*}{1} & 1 & $\mathbf{N}$ & $\mathrm{N}$ & - & N/A & $\begin{array}{l}\text { Intermittent machine marks confirmed } \\
\text { on Construction Radiographs }\end{array}$ \\
\hline & 2 & $\mathbf{N}$ & $\mathbf{N}$ & N/A & N/A & N/A \\
\hline & 3 & $\mathbf{N}$ & $\mathbf{Y}$ & $270^{\circ}$ & $6.7^{\prime \prime}$ & Nozzle weld, transition side of root \\
\hline & 4 & $\mathbf{N}$ & $\mathbf{Y}$ & $90^{\circ} \& 270^{\circ}$ & 1. $90^{\circ} 5.3^{\prime \prime}$ & 1. Noz. Weld, transition on side of roc \\
\hline & & & & & 2. $270^{\circ} 4.9^{n}$ & $\begin{array}{l}\text { 2. Noz. Weld, multiple circumferentia } \\
\text { cracks, transition side of root }\end{array}$ \\
\hline & & & & & & 3. Noz. Weld, nozzle side of root \\
\hline & & & & & 3. $270^{\circ} 5.5^{n}$ & \\
\hline \multirow[t]{5}{*}{2} & 1 & $\mathbf{N}$ & $\mathbf{Y}$ & $\begin{array}{c}\text { Essent. Top } \\
\text { Dead Center }\left(0^{\circ}\right)\end{array}$ & $5.1^{\prime \prime}$ & Noz. Weld, transition side of root \\
\hline & 2 & $\mathrm{~N}$ & $\mathbf{N}$ & N/A & $\mathbf{N} / \mathbf{A}$ & N/A \\
\hline & 3 & $\mathbf{N}$ & $\mathbf{Y}$ & $90^{\circ} \& 270^{\circ}$ & $\begin{array}{l}\text { 1. } 90^{\circ} 0.4^{\prime \prime} \\
\text { 1. } 90^{\circ} 2.4^{\prime \prime}\end{array}$ & 1. Noz. Weld, transition side of root \\
\hline & & & & & 2. $270^{\circ} 6.7^{n}$ & 2. Noz. Weld, transition side of root \\
\hline & 4 & $\mathbf{N}$ & $Y$ & $90^{\circ}$ & $1.6^{\prime \prime}$ & Noz. Weld, transition side of root \\
\hline
\end{tabular}

I Radiographic Inspections performed in 3/92 were performed using high sensitivity "M" grade film and greater source to film distance.

Figure 27 shows the extent and orientation of some of the primary cracks (TVA 1992a). Although only one of the cracks had penetrated the wall, the other five cracks shown were 50 to $80 \%$ throughwall. Figure 18 shows the primary and secondary cracking at the 270-degree location of Steam Generator 3 at Unit 1 . The cracks on the Unit 1 steam generators were at the 90- and 270-degree locations, which indicates that the elevation of the hot and cold fluid interface might have been at the horizontal centerline of the pipe during periods of auxiliary feedwater operation. Thermal striping at the interface may have caused crack initiation, and the cracks were then propagated by cyclic thermal stratification. The crack locations on Unit 2 are more difficult to explain. The cracks on Steam Generator 3 at Unit 2 were rotated approximately 30 degrees clockwise from the 90-to-270-degree line, and the crack on Steam Generator 1 at Unit 2 was located near the top of the pipe. Two possible explanations for these asymmetric crack profiles are (a) the elbow may be in a plane inclined to the vertical plane instead of in the vertical plane, or (b) the counterbore may have an asymmetric geometry.

All eight nozzles in Units 1 and 2 had been inspected several times prior to the time that the reported leakage occurred, but no cracks were detected (Coley 1992). Initial radiographic examinations were performed at the end of construction in 1979. The first inservice inspection examinations in accordance with Bulletin 79-13 were performed during the refueling outage in 1982, at the end of Cycle 1. Augmented inspections of one loop per refueling outage were initiated in 1983 and expanded in 1988 to all four loops per refueling outage (Cycles 4 and higher on Unit 1 and Cycles 3 and higher on Unit2). During these inspections, indications were 


\section{UNIT 1}

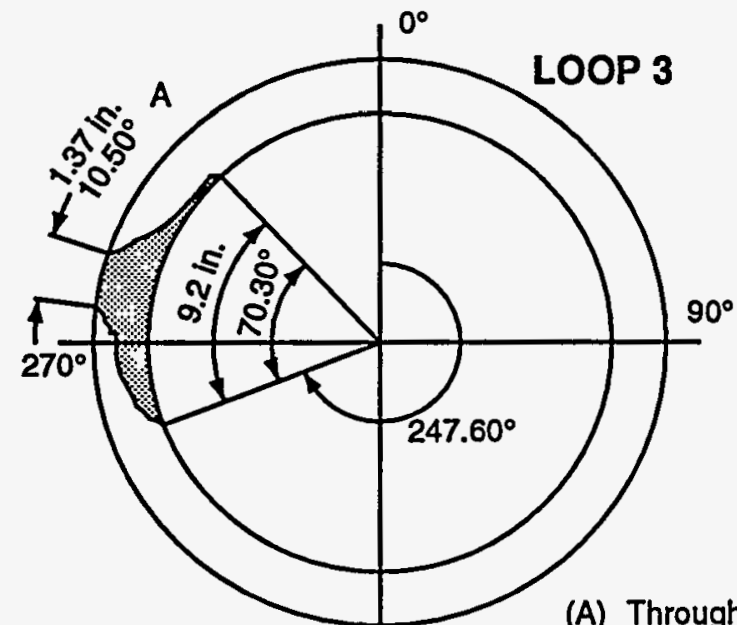

(A) Through - wall

(B) $50 \%$ through - wall

(C) $60 \%$ through - wall

(D) $80 \%$ through - wall

(E) $60 \%$ through - wall w/ similar parallel crack on other side of weld

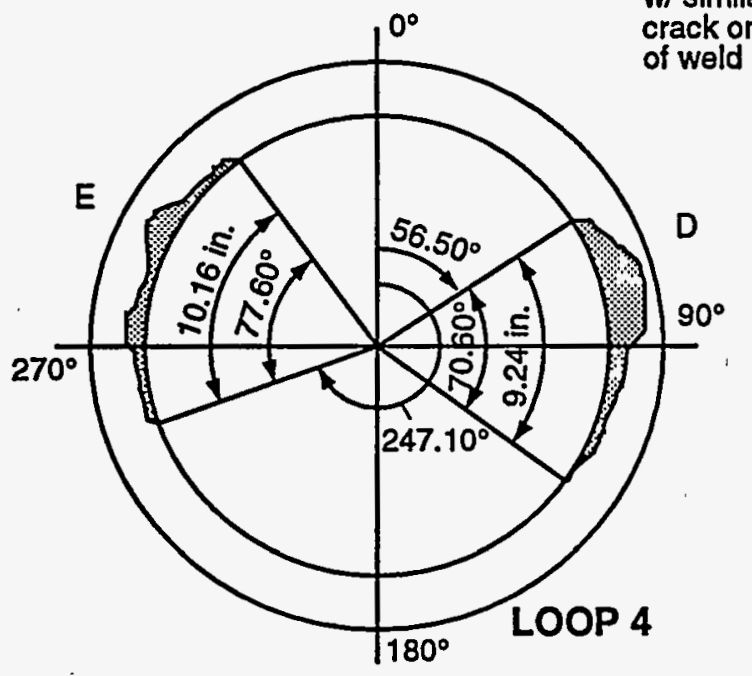

\section{UNIT 2}

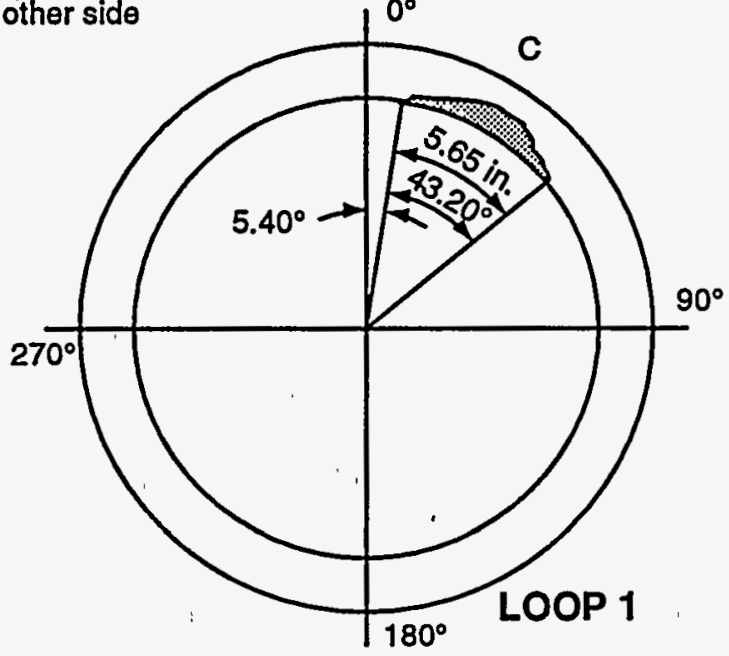

M95 0198

Figure 27. Extent and orientation of primary cracks in feedwater nozzle-to-transition field weld at Sequoyah Units 1 and 2 found in 1992 (TVA 1992a). 
recorded at the sites where cracks were later confirmed, but they were misinterpreted as geometry effects.

The licensee has stated that the inspection weaknesses involved limitations in the UT procedure and the inspector qualifications (TVA 1992a). It appears that the main weakness was the recording of indications as caused by a geometry effect without further verification with enhanced inspection techniques. The UT was performed according to the American Society of Mechanical Engineers (ASME) Code Section XI requirements and using intergranular stress corrosion cracking (IGSCC) methodology. The UT techniques and procedures were neither optimized nor adjusted for the specific configuration of the weld-counterbore region. The inspection personnel were EPRI qualified in IGSCC techniques, but since there is no industry qualification method available for identification of thermal fatigue, the inspectors were not trained to identify thermal fatigue cracks.

Several corrective actions were subsequently instituted at the two Sequoyah plants (TVA 1992a). Baseline radiographic and ultrasonic examinations of the replaced piping has been performed. The inspection personnel have received enhanced training by practicing on the cracked portions of the feedwater piping that have been replaced. The cracking event has been reviewed with the inspection personnel who now know that the feedwater piping is susceptible to thermal fatigue cracking, that the cracks can grow rapidly and are now familiar with the location and position of the expected cracks. In addition, the inspection personnel have also learned how to differentiate between geometric reflectors and thermal fatigue cracks as detected by ultrasonic examination. The inspection procedures have also been upgraded. The current surveillance instructions call for $100 \%$ volumetric inspection of the transition pieces, the nozzle-to-transition piece welds, the auxiliary-to-main feedwater line welds, and base metal adjacent to each weld for a distance of two wall thicknesses. These welds will be volumetrically examined by UT, supplemented by RT when specified by TVA Engineering. And all areas will be examined each refueling outage, with the exception of the auxiliary-to-feedwater line area, which will have a longer inspection interval. Loops 2 and 4 will be inspected every even-numbered outage, and Loops 1 and 3 will be inspected every odd-numbered outage.

Metallographic Evaluation-A destructive examination was performed on the Unit 1, Steam Generator 3 transition piece containing the through-wall crack, which included the adjacent welds and the nearby adjoining sections of the feedwater nozzle and pipe. The examination revealed that the through-wall crack initiated at the inside surface and propagated both circumferentially and radially, reaching the outside surface and resulting in the leak. The circumferential extent of the crack was about $234 \mathrm{~mm}$ (9.2 in.) at the inside surface and about $32 \mathrm{~mm}(1.25 \mathrm{in}$.) on the outside surface. The crack was nonbranching and open, as shown in Figure 26 (TVA 1992b). Oxide wedging might have kept the crack from closing. (Although no mention was made of the presence of oxides in the crack in the TVA reports, their existence is presumed because they are reported to be present on the inside surfaces and in the secondary cracks.) The propagation of the crack, shown in Figure 28, followed a straight path directly into the weld, remaining nearly normal to the pipe surface instead' of following a path along the weld fusion line (TVA 1992b).

The examination of the crack surface revealed striation marks, which indicate fatigue damage. The licensee reported that the examination also revealed some evidence of thermal striping at the inside surface at about the 270-degree circumferential location. The number of crack arrest points found on the crack surface may correspond to the same number of low power or hot standby cycles during which activation of the auxiliary feedwater system caused crack propagation. The crack surface was oxidized and had different colors at various points along the crack front through the pipe wall, which indicates that a major portion of the crack had existed for a significant period of time. The crack surface was relatively smooth and free of extensive corrosion pitting or erosion. 


\section{FIELD EXPERIENCE}

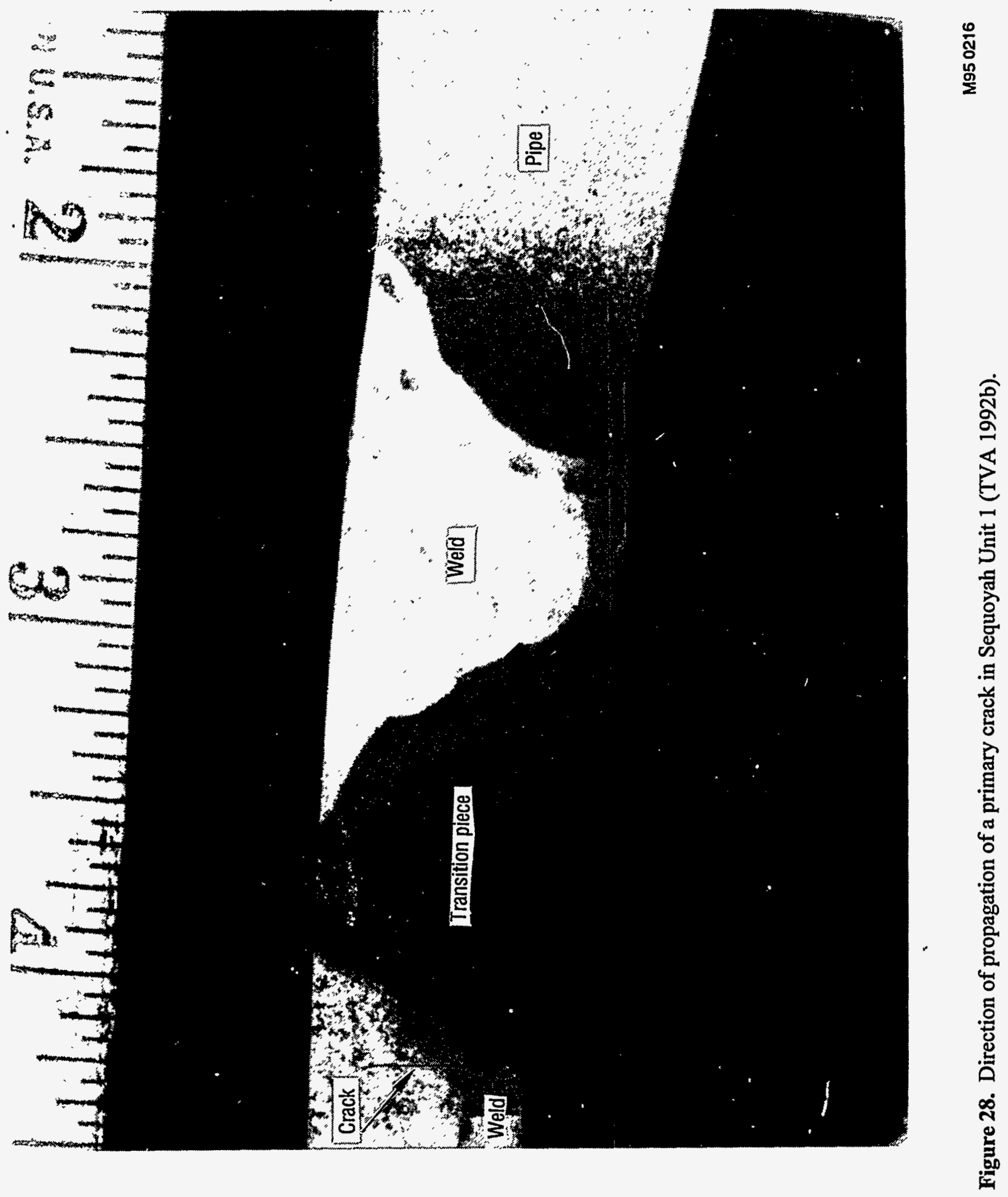


Pits were observed adjacent to the nozzle-totransition piece weld bead. These pits linked in a circumferential pattern. The linked pits could provide an area of stress concentration, more intense than a single pit, that may lead to fatigue crack initiation. A deposit of copper (49.8\% weight as oxide), nickel ( $3.6 \%$ weight as oxide), and iron (balance) was found on the inside surface of the elbow. Copper oxide promotes pitting and corrosion fatigue.

The microscopic examinations also revealed multiple secondary cracks adjacent to the throughwall primary crack in the weld heat-affected zone and the base metal of the transition piece (Figure 18). These secondary cracks were orientated circumferentially, as was the primary crack, but were much shallower than the primary crack. The secondary cracks were numerous in the direct vicinity of the primary crack, but diminished about $13 \mathrm{~mm}(0.5 \mathrm{in}$.) away from the primary crack along the transition piece. These cracks appear to have been propagating slowly through the wall, because a significant stress concentration was absent, and the primary crack could have relieved the stresses in the vicinity of these cracks. The secondary cracks were filled with a tight, dense oxide, presumed to be magnetite, and extended to a maximum of $10 \%$ of the wall thickness. Most of the cracks followed a straight path; however, some displayed multi-branching and could have resulted from several different causes. Fatigue caused by cyclic thermal stresses or stress-assisted corrosion, and intensified by oxide wedging are possible mechanisms.

Other minor cracks were detected in the counterbore region; these cracks were shallow and had no obvious branching. This area was essentially free of corrosion pitting, and there was no observed flow-accelerated corrosion damage.

Root Cause Analysis-The root cause of the cracking is attributed to thermal fatigue caused by periodic thermal stratification when cold auxiliary feedwater was injected into the steam generator during Mode 3 operations. This is consistent with the root causes identified for similar cracking that has occurred at other PWRs.
Stratification in the feedwater piping leads to three types of cyclic loadings: global thermal stratification, which results in bowing of a long, horizontal pipe; cyclic or local thermal stratification, which occurs locally when the water level fluctuates up and down; and thermal striping (Cofie et al. 1994). The portion of the feedwater piping adjacent to the feedwater nozzle is mainly subject to cyclic thermal stratification and thermal striping, whereas the feedring is mainly subject to global stratification. Thermal striping at the interface between the hot and cold fluid layers in the nozzle results in high-cycle fatigue, which initiates cracking. Evidence of thermal striping has been observed in laboratory tests conducted at Westinghouse on piping of similar design $(\mathrm{Hu}$, Houtman, and White 1981).

The stress concentrations present because of the counterbore, and in some cases the weld, increase the stresses at the inner surface of the transition piece region and make it susceptible to fatigue crack initiation. Figure 18 shows initiation of the primary crack at a stress concentration caused by the weld geometry and the transition piece inclination. In this case, the weld has formed a notch with the transition piece resulting in a stress concentration greater than that of the transition piece inclination alone. Once a crack is initiated, propagation results from cyclic thermal stratification caused by on-off auxiliary feedwater operation.

The auxiliary feedwater system can be operated in either the automatic or the manual mode. In the automatic mode, full flow from the auxiliary feed pumps [about 760 to $830 \mathrm{l} / \mathrm{min}$ (200 to $220 \mathrm{gpm}$ )] is initiated whenever the level in the steam generator is low, and is terminated when the level has been increased to a sufficiently high level. This results in on-off operation of the auxiliary feedwater flow, estimated to be approximately three times per hour. In the manual mode, the operators adjust the auxiliary feedwater flow rate to match the loss of water in the steam generator by recirculating a portion of the flow from the auxiliary feed pumps back to the condensate storage tank, as shown in Figure 8. 
During periods of auxiliary feedwater operation, the flow partially fills the horizontal portion of the nozzle region, leading to the stratified fluid condition shown in Figure 25. The cold auxiliary feedwater [about 20 to $38^{\circ} \mathrm{C}\left(70\right.$ to $100^{\circ} \mathrm{F}$ )] fills the lower portion of the horizontal portion of the feedwater line and nozzle, and hot fluid [about $\left.286^{\circ} \mathrm{C}\left(547^{\circ} \mathrm{F}\right)\right]$ from the steam generator fills the upper portion. When the auxiliary feedwater flow is terminated, the nozzle region temperature returns to the hot condition, and then when flow is reinitiated, the stratified condition is reestablished. This on-off auxiliary feedwater operation leads to cyclic thermal stratification. Figure 29 shows typical auxiliary feedwater flow rates with the auxiliary feedwater cycling on and off during automatic operation.
Fatigue damage progresses much more rapidly in the automatic mode, during which the flow fluctuates between 0 and about $760 \mathrm{l} / \mathrm{min}(200$ $\mathrm{gpm}$ ) at a rate of approximately 3 times per hour and cyclic thermal stratification takes place, than in the manual mode, during which the flow is relatively constant at about $300 \mathrm{l} / \mathrm{min}(80 \mathrm{gpm})$ and large fluctuations in the flow rates are absent. The automatic mode of operation, because of the relatively high flow rates, might also be producing thermal striping at the interface between the cold auxiliary feedwater and the hot fluid from the steam generator. Thermal striping imposes highcycle stresses on the pipe inside surface and contributes to crack initiation. (See Section 7.1 for a description of thermal stratification, thermal striping, and thermal cycling.) In the automatic

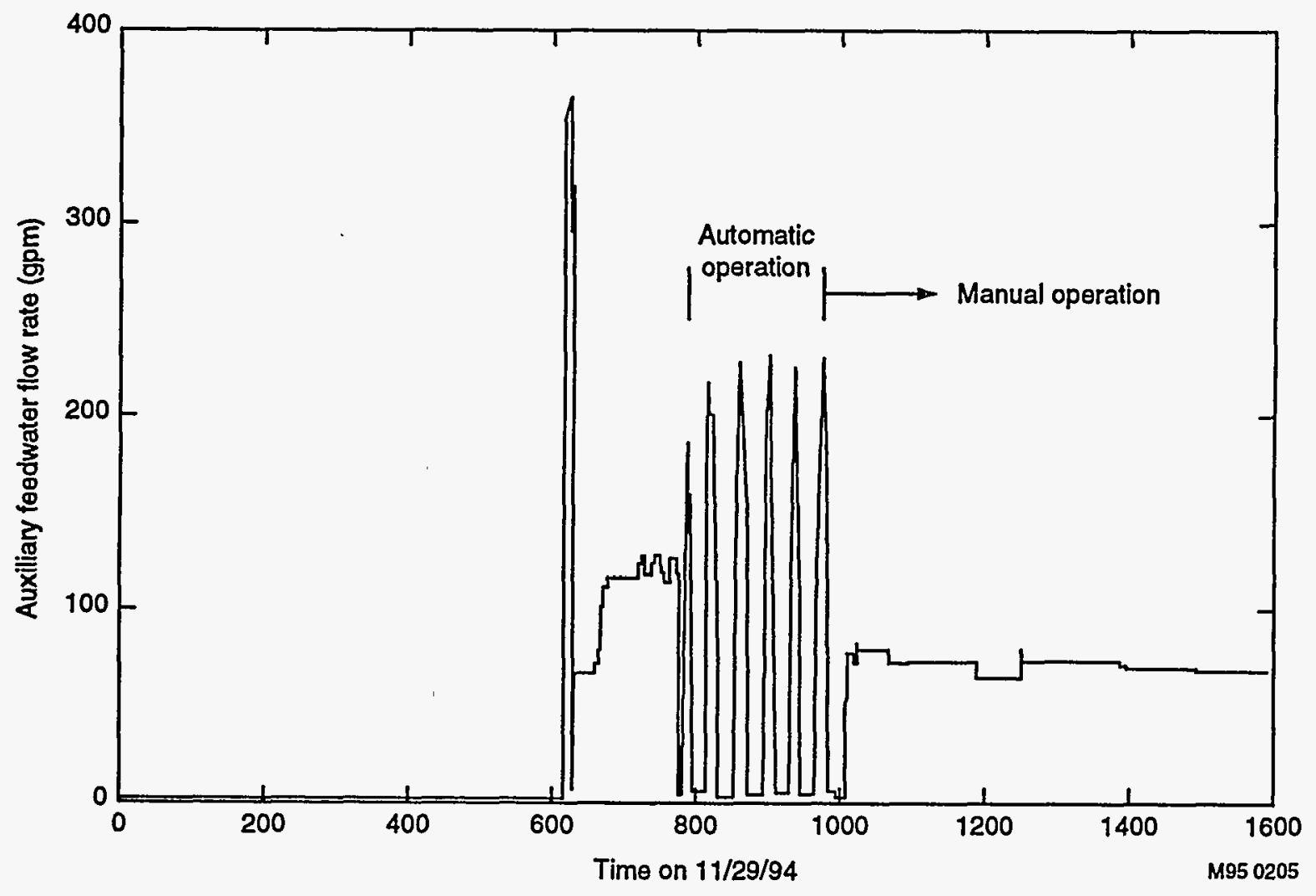

Figure 29. Loop 1 auxiliary feedwater flow rates during manual and automatic operation at Sequoyah Unit 1 on November 29, 1994. Courtesy of W. Ludwig, TVA. 
mode of operation, the auxiliary feedwater flows at about $760 \mathrm{l} / \mathrm{min}$ and fills the lower half of the feedwater piping cross section as shown in Figure 25. The pipe wall inside surface, near the interface, is probably subject to high-cycle fatigue damage caused by thermal striping.

Cracking Incidents in 1993. A subsequent ultrasonic examination at Sequoyah in 1993 (less than one fuel cycle later) revealed circumferential indications in five of the eight replaced transition pieces, including Loops 2 and 3 of Unit 2 (Cofie et al. 1994), and Loops 1, 2, and 4 of Unit 1. Loop 2 of Unit 2 was the only loop where the UT located an indication on the nozzle side of the nozzle-totransition piece weld; all the other indications were located in the transition piece within $13 \mathrm{~mm}(0.5$ in.) of the weld centerline. Radiographic inspection was not able to confirm any of these indications. UT and RT of the auxiliary feedwaterto-feedwater piping connection did not detect any indications.

After indications were discovered in Loops 2 and 3 of Unit 2 in April 1993, time limits were placed on the auxiliary feedwater operation. Limits of 60 allowable hours of automatic mode auxiliary feedwater operation and 600 hours of manual operation were established. During periods of operation after heatup in October 1993, the hours of auxiliary feedwater use were recorded, and the remaining hours of allowable operation were determined. In addition, crack growth rates for periods of auxiliary feedwater operation were used to estimate possible increases in crack depths. Over the period from October 1993 to July 1994, calculations estimated that an initial $2.5-\mathrm{mm}$ (0.1-in.) long crack would have grown to $3 \mathrm{~mm}$ (0.123 in.).

Repair and Mitigation. It has been recognized as part of the overall PWR steam generator feedwater nozzle cracking problem that the auxiliary feedwater operation was a root cause. Consequently, an evaluation of the auxiliary feedwater operating time began in 1988. It became obvious that the hours of auxiliary feedwater operation should be minimized, particularly in the automa- tic mode. In addition, an operating procedure review was conducted by Westinghouse, and the following three recommendations were made to reduce the impact of auxiliary feedwater operation on the feedwater nozzle stresses (TVA 1992a):

1. The operating procedures were changed so that a change from the automatic to the manual mode of auxiliary feedwater operation is made as soon as possible after a reactor trip,

2. The auxiliary feedwater recirculation line was modified so that during manual operation the net flow of auxiliary feedwater to a steam generator would be about 300 to $340 \mathrm{l} / \mathrm{min}(80$ to $90 \mathrm{gpm})$, and

3. The operating conditions during steady state Mode 3 operations were revised such that the use of the auxiliary feedwater system in the automatic mode is reduced.

After the 1992 cracking, all eight transition pieces were replaced with the same design (in-kind replacement), and the plants were returned to service. The corrective actions discussed earlier are summarized here (TVA 1992a):

- Baseline RT and UT of the replaced pieces were conducted,

- The ISI requirements were upgraded; for example, a $20 \%$ DAC (distance-amplitude correction) ${ }^{1}$ recording level for indications has been established, inspection areas have been expanded to $100 \%$ of the weld volume plus the base metal for two wall thicknesses on either side of the weld, and indications are evaluated using enhanced UT methods (such as a high-angle longitudinal wave),

1 The distance-amplitude correction curves compensate for the attenuating effects of the material such that the amplitude response from unknown reflectors can be evaluated and compared to that of the calibration reflector independent of distance. 
- The event was reviewed with ISI personnel, and enhanced training was provided using the removed pieces of the damaged feedwater piping and nozzle, and

- Additional confirmatory inspections (RT and UT) have been implemented.

Long thermal liners with 356-mm (14-in.) inside diameters were installed in loops 2 and 3 of Unit 2. The thermal liner, shown in Figure 30, extends over the nozzle-to-transition piece weld, transition piece, transition piece-to-elbow weld, and a portion of the elbow and protects these components from the fatigue damage caused by thermal stratification and striping. It is estimated that the thermal liner is capable of sustaining the thermal fatigue loads caused by about $900 \mathrm{~h}$ of automatic operation of the auxiliary feedwater system. Online fatigue monitoring of Loops 2 and 3 of Sequoyah Unit 2 is being continued and it includes monitoring of both main and auxiliary feedwater temperatures.

There are two potential concerns about the structural integrity of the liner: (1) wall thinning of the liner by the flow-accelerated corrosion process, and (2) fatigue cracking of the liner. The first concern has been addressed by selecting SA-335,

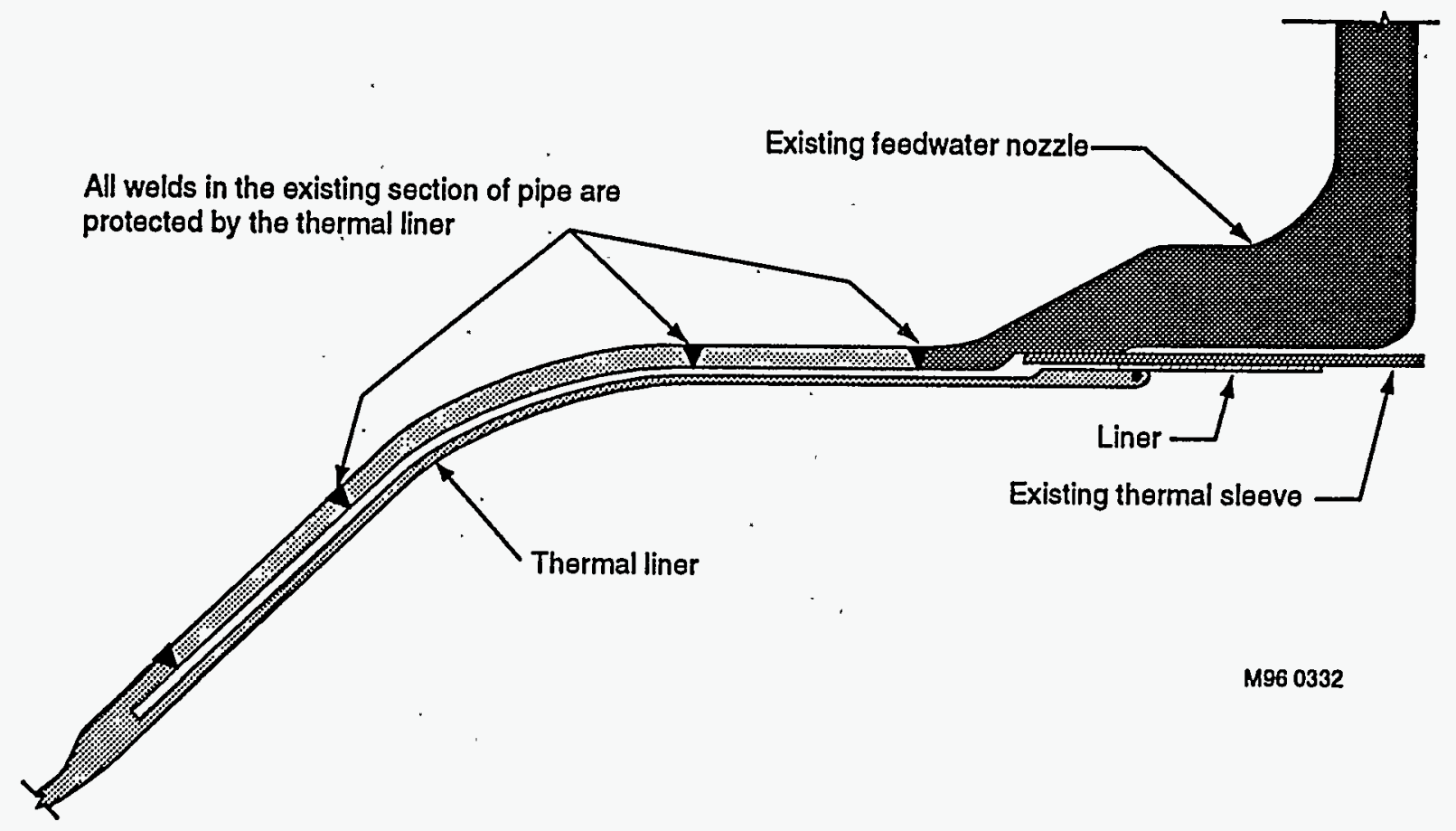

Figure 30. New thermal liner protecting the feedwater nozzle and elbow from thermal stratification loadings (Cofie et al. 1994). Copyright American Society of Mechanical Engineers; reprinted with permission. 
Grade P11 as a liner material. The chromium content of this material is in the range of 1.0 to $1.5 \mathrm{wt} \%$; therefore, as discussed in Section 7.2, significant wall thinning of the liner will not take place. ${ }^{1}$ The second concern about fatigue cracking can be addressed by monitoring the outside wall temperature of the piping components protected by the liner. If there is any leakage of auxiliary feed water through the liner, it will affect the wall temperatures, which can be detected by the monitoring system. There is also a concern that thermal fatigue might damage the liner and produce loose parts. However, the broken pieces of the liner would have to be of such small size that they can pass through the 51-mm (2-in.) diameter J-tubes in order to damage the steam generator tubes. Long thermal liners have also been installed at other PWRs (for example, the Turkey Point units).

Two other steps in addition to the installation of the thermal liner have been taken to provide protection against thermal fatigue damage: elimination of stress raisers and improved water chemistry. The end of the feedwater nozzle was built up such that there is no change in the wall thickness from the feedwater nozzle to transition piece, which eliminates the stress raiser where fatigue cracking occurred earlier. At least one other PWR has its feedwater nozzle ends built up to eliminate the stress raiser. Figure 31 shows how the counterbore region can be redesigned to eliminate the stress raiser. The utility is also eliminating copper from
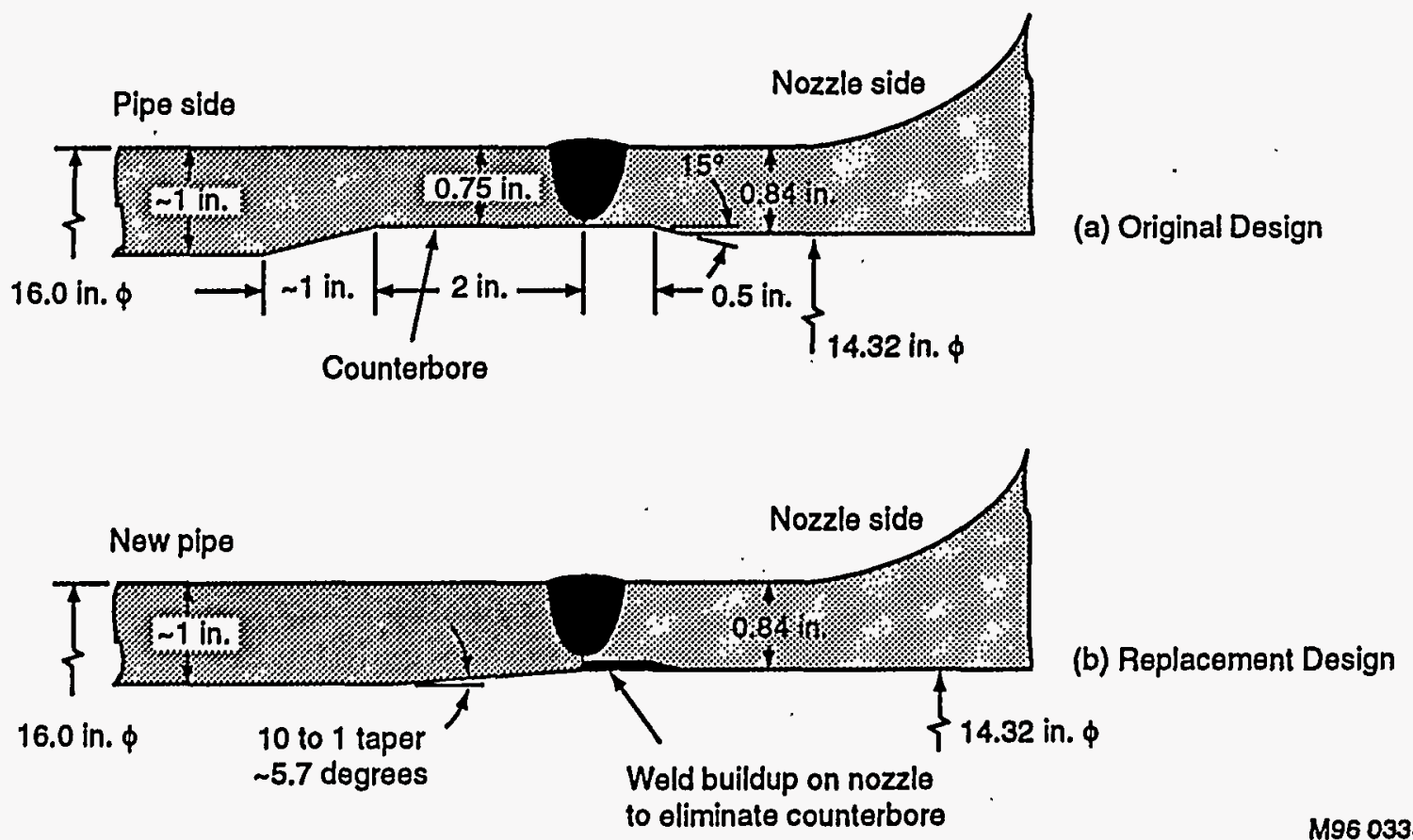

Figure 31. Weld buildup to eliminate counterbore as a stress raiser (Cofie et al. 1994). Copyright American Society of Mechanical Engineers; reprinted with permission.

\footnotetext{
I V. N. Shah, private communication with K. House, TVA, Chattanooga, Tennessee, July 26, 1996
} 
all the feedwater system components. The tubes in the condenser, which are made from copperbearing material, are being replaced with titanium tubes.

\subsubsection{Diablo Canyon Units 1 and 2}

Diablo Canyon Units 1 and 2 are 4-loop Westinghouse PWRs. Figure 32 is a drawing of the SA-508 Class 2 steam generator nozzle and the adjacent SA-106 Grade B feedwater piping, typical for both units. A $51-\mathrm{mm}$ (2-in.) long transition piece was field welded to the nozzle at the downstream end. At its upstream end, it is welded to a $203-\mathrm{mm}$ (8-in.) long horizontal section of pipe, which in turn is welded to a 45-degree elbow. Figure 17 shows a construction drawing of the field welds (Cofie et al. 1994). The inside surfaces were counterbored in this region, resulting in a reentrant corner on each side of the weld at the transition to the thinnest section. Figure 17(a) shows that the thickness change is more pronounced, and the counterbore reentrant angle is more notched on the upstream side of the transition piece-to-nozzle weld than for either the downstream side of this weld or for a typical transition piece-to-pipe weld counterbore. The transition piece-to-pipe counterbore, shown in Figure 17(b), has a reentrant angle of 166 degrees, versus 150 degrees for the transition piece-tonozzle weld. Fatigue cracking typically occurs circumferentially around the pipe at the upstream end of the transition piece-to-nozzle weld, where the stress concentration is significantly more severe.

This section presents a brief history of operation and inservice inspection at the two units, a summary of the cracking that was discovered in 1992, results of the metallographic examinations of the cracks, results of the root cause analysis (including a discussion of plant operation that affects feedwater nozzle cracking), and repair and mitigation efforts that have been undertaken at Diablo Canyon.

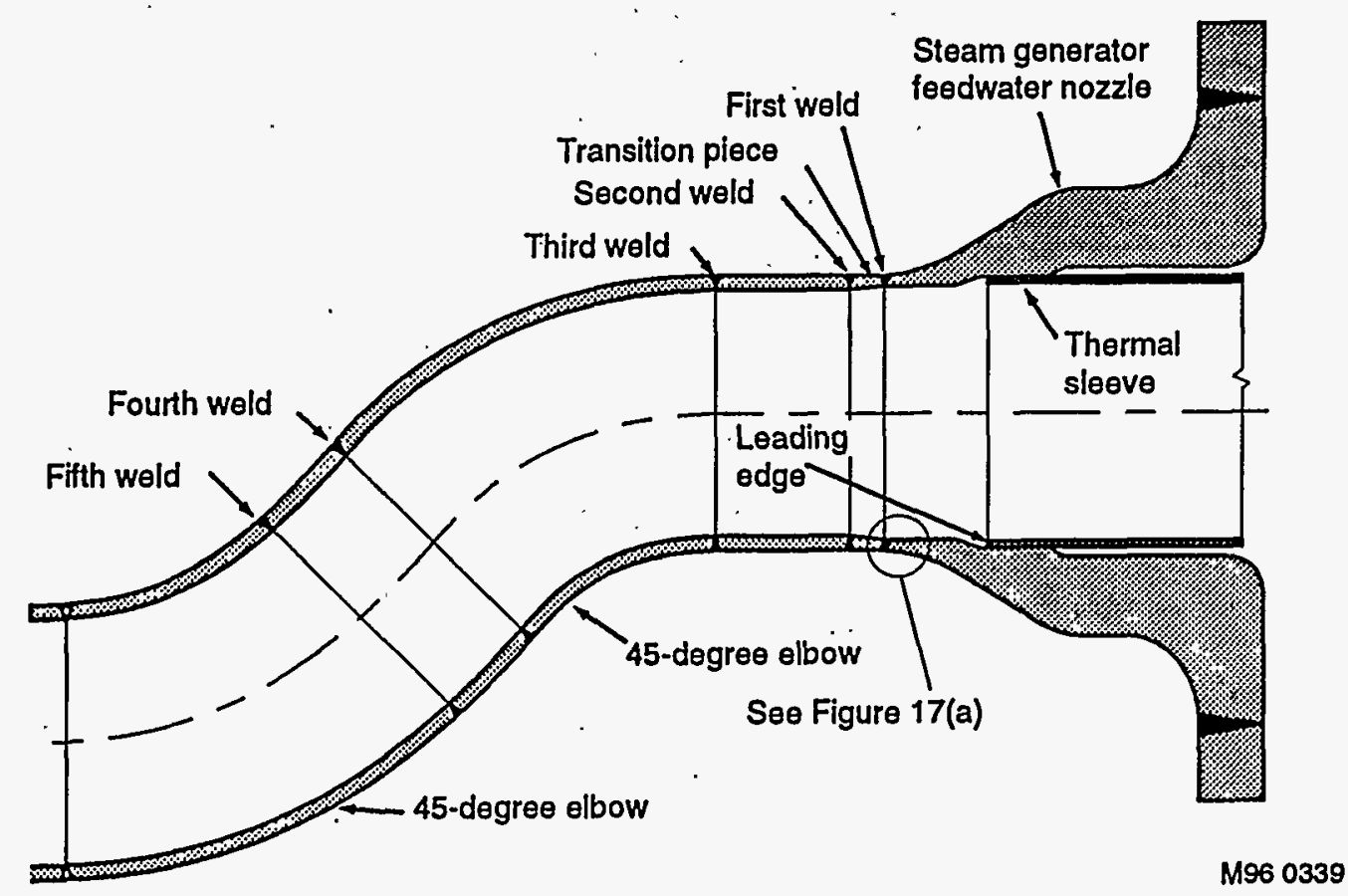

Figure 32. Feedwater nozzle area layout at Diablo Canyon Units 1 and 2 (Shvarts et al. 1994). Copyright American Society of Mechanical Engineers; reprinted with permission. 
Past History. The Unit 1 steam generator field welds were originally completed in 1974 in accordance with ASME Section I (Power Boilers) requirements, rather than ASME Section III. In 1977, the nozzle-to-transition piece field weld on Steam Generator 2 of Unit 1 developed a throughwall crack, resulting in a leak during hot functional testing. Subsequent UT and RT revealed a 154-mm (6-in.) long circumferential crack in the heat-affected-zone off the weld root (Stoller 1979). The Unit 2 welds were originally completed in 1978, using an improved weld procedure derived from the lessons learned from the Unit 1 weld failure. The improved procedure included maintaining the preheat temperature until the postweld heat treatment.

In response to Bulletin 79-13, the first inspection of Unit 1 was performed after hot functional tests in 1979. Based on the inspection results, the transition pieces on Unit 1 were replaced (in-kind) in 1980 (Cofie et al. 1994). The full power operating license was issued in 1984 after successful completion of a design verification program. During the first refueling outage in 1986 , examinations were completed in response to Bulletin 79-13, and the piping and welds were found to be acceptable under ASME Section XI requirements. The second refueling outage inspection was conducted in 1988, with no reported indications. The Unit 2 Bulletin 79-13 inspections were conducted during the first refueling outage in 1987, and piping and welds were found to be acceptable under ASME Section $\mathrm{XI}$ requirements.

The feedwater chemistry during operation was as follows. The $25^{\circ} \mathrm{C} \mathrm{pH}$ at Diablo Canyon had varied in the range of 8.7 to 9.1 ; for the most recent period, it had been in the range of 8.9 to 9.1. The typical oxygen in the main feedwater was less than $5 \mathrm{ppb}$, whereas the oxygen content of the auxiliary feedwater might be as high as 100 $\mathrm{ppb}$. The dissolved oxygen content in the Diablo Canyon Unit 1 condensate storage tank was measured over a period of about 3 years (Peterson

I V. N. Shah, private conversation with Lee Goyette, PG\&E, March 2, 1995.
1992). The average reading was $15.5 \mathrm{ppb}$, but on two occasions rose to $100 \mathrm{ppb}$. Copper condenser tubes were replaced with titanium tubes after the first fuel cycle, which resulted in a smaller amount of copper oxide present in the coolant.

1992 Cracking Incident. Based on the cracking found at Sequoyah, an enhanced inspection was conducted during the Unit 1 fifth refueling outage in September 1992. PG\&E conservatively determined from ultrasonic examinations that linear, circumferential indications on the feedwater piping adjacent .0 three of the steam generator feedwater nozzles of Diablo Canyon Unit 1 exceeded the ASME Code Section XI flaw acceptance criteria. Linear indications were also found in the fourth steam generator but did not exceed the ASME Code criteria. The indications were near the nozzle-to-pipe welds, as shown in Figure 17(a) (PG\&E 1992, Cofie et al. 1994). Radiographs of the area did not reveal any cracks, but a visual examination after cutting out the section of pipe in the degraded region detected the possibility of degradation. Consequently, the licensee decided to replace the piping in the vicinity of the degradation and to conduct a metallurgical examination of some of the degraded portions.

In addition, thinning of the leading edge of the carbon steel thermal sleeves was found on all four Unit 1 steam generators, but the licensee concluded that the sleeves were acceptable for continued operation. Although no linear indications were found at Unit 2, thinning of the leading edge was observed on some of the thermal sleeves.

Magnetic particle testing (MT) of the elbow after it was cut out revealed a few indications. Ultrasonic examinations estimated the deepest indications on the four steam generators as follows: $\begin{array}{ll}\text { SG 1-1 } & \text { 0.76-mm (0.030-in.) deep, } \\ & \text { 197-mm (7.75-in.) long }\end{array}$

SG 1-2 0.25-mm (0.010-in.) deep, 51-mm (2-in.) long intermittent 


\author{
SG 1-3 2.7-mm (0.107-in.) deep; \\ 360-degree intermittent, longest \\ $51 \mathrm{~mm}(2 \mathrm{in}$.
}

SG 1-4 1.2-mm (0.047-in.) deep, 3.2-mm (0.125-in.) long

Metallographic examination results for two samples of pieces cut out from Unit 1 Steam Generators 1 and 3, discussed in the next section, determined that the deepest crack was $1.5-\mathrm{mm}$ (0.060-in.) deep (Aguiar 1993). The allowable ASME Code depth is $10.2 \mathrm{~mm}$ (0.400 in.).

Based on a review of the previous radiographic records performed in response to Bulletin 79-13, the licensee determined that the records were incomplete; the pipe-to-transition piece welds were radiographed, but the nozzle-to-transition piece welds were not. Also the radiographic techniques used in the Unit 1 1979, 1986, and 1987 outages may not have been in full compliance with Bulletin 79-13 guidance, such as penetrameter thickness, ${ }^{1}$ sensitivity, and density values, but the 1985 Unit 2 inspection was in full compliance with the guidance. However, based on examinations of the removed sections from Unit 1 , the licensee believes that the small thermal fatigue cracks would not have been detected.

Based on the experience at the Sequoyah units, planning for enhanced inspections of the Unit 1 nozzles began in May 1992. The experience in previous inspections at Sequoyah and Turkey Point were reviewed, and multiple techniques were chosen for use at Diablo Canyon Unit 1, including both enhanced manual and automated UT techniques. The past experience had shown that the ASME Code examinations were not adequate to detect tight thermal fatigue cracks, and use of enhanced UT techniques was desirable. The UT

\footnotetext{
1 A strip of sheet metal is placed on the pipe wall and must be seen in the radiograph. This serves as a type of online calibration.
}

system was calibrated using a sizing notch block. ${ }^{2}$ The results from the feedwater piping were not immediately conclusive because the signals were of low amplitude. They had some crack-like signal characteristics, and there were no geometrical origins. A single-wall radiography was also performed by using the access provided by the gamma plug. Using single wall shots with maximum source/film distance ${ }^{3}$ did not reveal any cracking on Steam Generator 4. Panoramic shots were used on Steam Generators 1 and 2, but, again, no cracks were detected. An examination by video probe showed possible indications that were not conclusive. However, the UT inspections with a tip diffraction technique revealed cracks at the counterbore discontinuity, the deepest being about $8.9 \mathrm{~mm}$ (0.35 in.).

Metallographic Evaluation-Samples of the transition pieces from two steam generators ( 1 and 3 of Unit 1 ) were removed for metallurgical examination. Magnetic particle testing of the samples ${ }^{4}$ showed that the cracking extended 360 degrees around the inside surface circumference, and was about $6 \mathrm{~mm}(0.25 \mathrm{in}$.) upstream of the transition-piece-to-nozzle-weld, at the counterbore reentrant corner. A crack that was identified by $\mathrm{UT}$ as $8.9-\mathrm{mm}(0.35-\mathrm{in}$.) deep was found to be only about $0.91-\mathrm{mm}$ (0.036-in.) deep (Aguiar 1993). Inclusions (aluminum oxides and manganese sulfides) found in the piping material may have caused the incorrect sizing with the tip diffraction technique, which is discussed in Section 8.2.1.

The major cracks had propagated perpendicularly into the wall and were nonbranching. The deepest crack was 1.5-mm (0.060-in.) deep (Aguiar 1993). Evidence of microcracking was found in the

\footnotetext{
2 Saw cuts were placed in a block, and the UT results were compared with the physically measured widths for calibration.

3 The source is placed on the back side of the pipe wall. This increases the resolution.

4 These magnetic particle tests performed in the laboratory were in addition to those conducted on site and discussed in Section 6.3.2.
} 
transition piece. There were multiple initiation sites, and some of the cracks joined randomly. The cracks propagated transgranularly into the metal, most penetrating only a small depth. Some of the cracks initiated at the bottom of corrosion pits, whereas others initiated at locations that showed no evidence of pitting. Most of the cracks contained traces of what appeared to be high-temperature oxide, and some cracks were completely filled with oxide. Some of the cracks had very blunt crack tips, and there were local areas where the crack surfaces were widely separated. These features are characteristic of corrosion fatigue.

Root Cause Analysis-The root cause of the cracking was attributed to thermal fatigue caused by periodic thermal stratification when cold auxiliary feedwater, typically with a fluctuating flow rate, is injected into the steam generator during Mode 3 operations. This is the same root cause identified at the other PWRs with similar cracking.

Oxygen in the feedwater was low, typically less than $100 \mathrm{ppb}$, but the oxidizing effects of the copper oxides which were found in the oxide deposits of the crack surfaces may have contributed to the corrosion fatigue. The licensee reports that the oxygen control has been very good over the plants' lifetimes. Although the cracks displayed some characteristics that resemble corrosion fatigue, the cracks did not contain the extensive buildup of oxides and other corrosion products usually associated with corrosion fatigue, so the licensee concluded that the cracking appears to be caused more by thermal fatigue than by corrosion fatigue (Aguiar 1993).

Typical auxiliary feedwater evolutions for the Diablo Canyon units are listed in Table 2 (Peterson 1992). These include typical durations and flow rates. The total times spent in Modes 2 and 3 operation as of 1992 were 339.47 days for Unit 1 and 239.58 for Unit 2. Auxiliary feedwater temperatures at Diablo Canyon are in the range of 20 to $38^{\circ} \mathrm{C}\left(70\right.$ to $\left.100^{\circ} \mathrm{F}\right)$ during Modes 2 and 3 operation, during which time the steam generator secondary coolant temperature is greater than $177^{\circ} \mathrm{C}\left(350^{\circ} \mathrm{F}\right)(\mathrm{PG} \& \mathrm{E} 1992)$.

The Diablo Canyon auxiliary feedwater system was designed for minimum flow rates on the order of $830 \mathrm{l} / \mathrm{min}(220 \mathrm{gpm})$ per steam generator during accident conditions (PG\&E 1992), but as the required flow is typically less than $830 \mathrm{l} / \mathrm{min}$ (220 gpm), fluctuations occur during automatic control operation. Figure 33(a) shows the temperatures during a cooldown on Unit 1 in 1992. The main steam temperature has been reduced from about 288 to $177^{\circ} \mathrm{C}\left(550\right.$ to $\left.350^{\circ} \mathrm{F}\right)$, and the feedwater temperature has decreased from about 120 to $40^{\circ} \mathrm{C}$ $\left(250\right.$ to $100^{\circ} \mathrm{F}$ ) over about 9 hours, whereas the auxiliary feedwater temperature has remained constant at $38^{\circ} \mathrm{C}\left(100^{\circ} \mathrm{F}\right)$. Figure $33(\mathrm{~b})$ shows the fluctuations in auxiliary feedwater flow rate during this period; the flow rate averages about $380 \mathrm{l} / \mathrm{min}$ (100 gpm). Plant data indicate that the auxiliary feedwater does not fill the nozzle until the flow rate reaches about $760 \mathrm{l} / \mathrm{min}(200 \mathrm{gpm})$ or more (Shvarts et al. 1994). Cycling involving changes in flow rates of about $380 \mathrm{l} / \mathrm{min}(100 \mathrm{gpm})$ occur at a rate of about 2 to 3 times per hour.

Figure 34 illustrates the flow in a straight feedwater pipe, showing that when the level oscillates from the bottom to the top of the pipe, the stress at location $P$ alternates between tension and compression. In both diagrams of Figure 34, the cold auxiliary feedwater is flowing under a layer of hot fluid, and as auxiliary feedwater flow rate fluctuates, the cold water level increases and decreases, producing cyclic stresses. The true end condition is neither fixed nor free, but is restrained somewhere between the two conditions. However, at point $P$, the stress reversal is the same. Similarly, damage can occur in the upper region of the pipe when the flow is higher, almost filling the pipe. Thermal striping also may be taking place at the interface between the hot and cold layers.

Repair and Mitigation. The licensee decided to replace (in-kind) the horizontal piping to all four Unit 1 feedwater inlet nozzles. During the Unit 2 seventh refueling outage, an enhanced 


\section{FIELD EXPERIENCE}

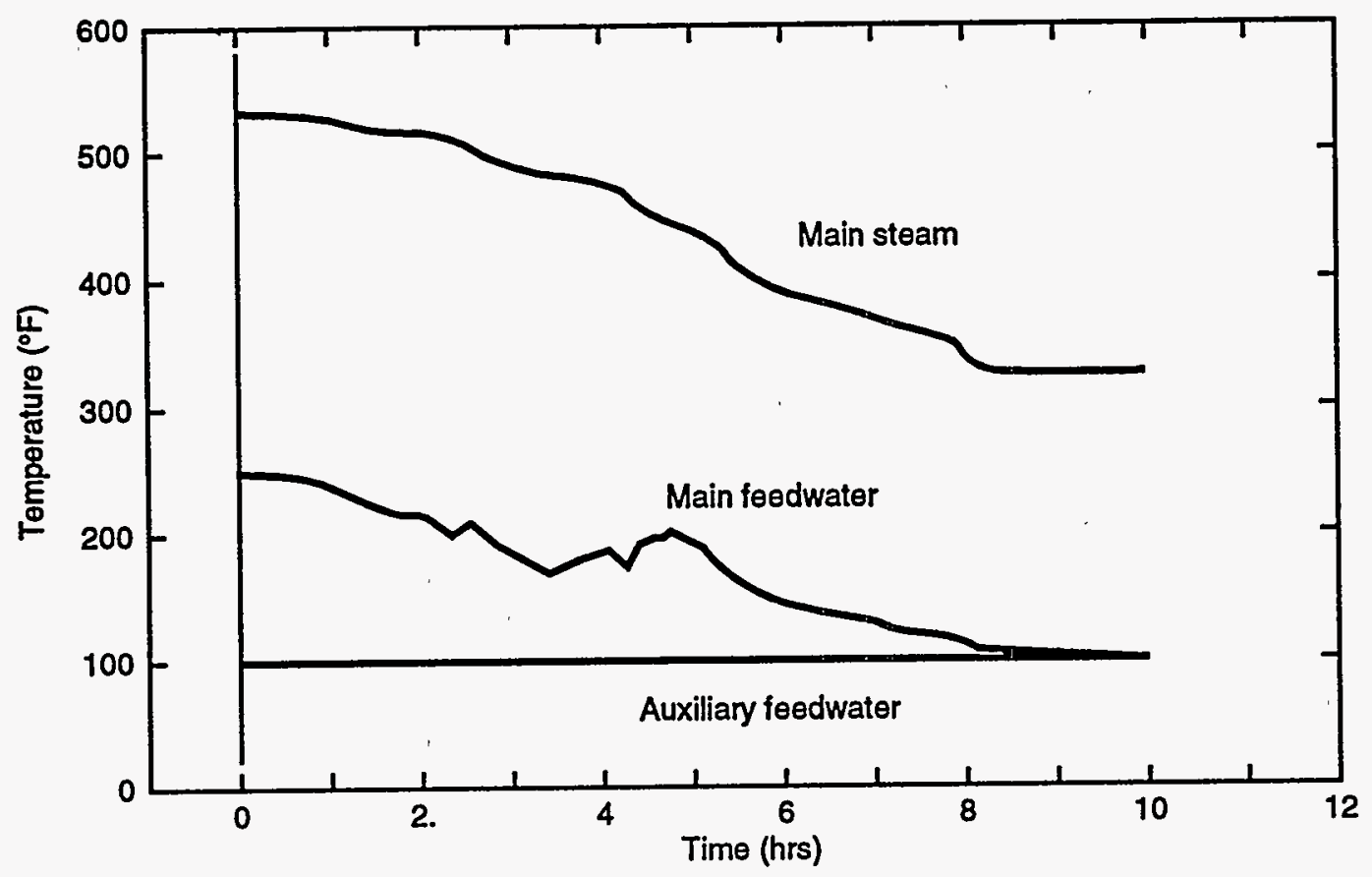

(a) Main steam, main feedwater, and auxiliary feedwater temperatures

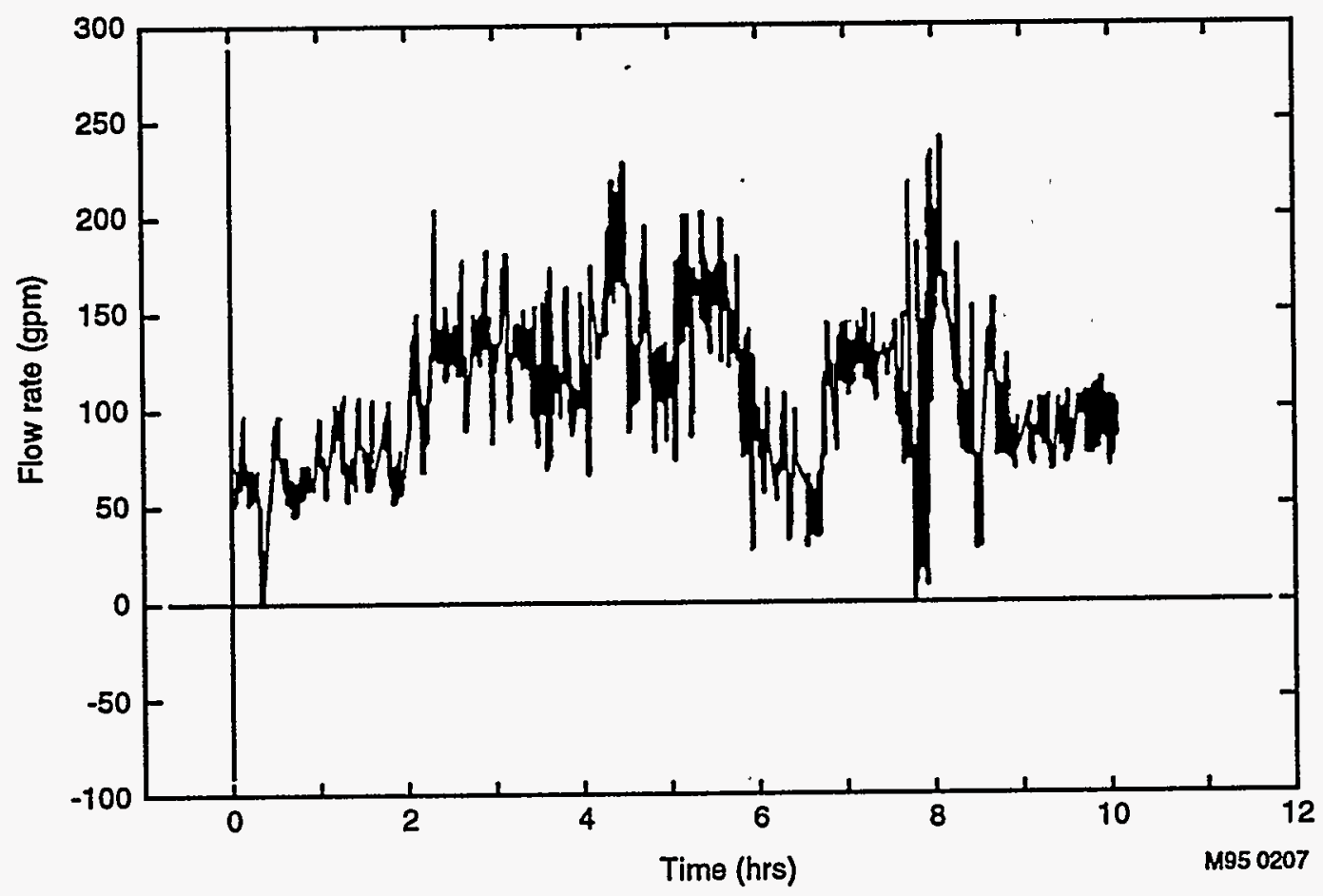

(b) Auxiliary feedwater flow rates

Figure 33. Temperatures and flow rate during cooldown on 9/13/92 at Diablo Canyon Unit 1 , Steam Generator 1 (Peterson 1992). 


\section{Stress profiles}
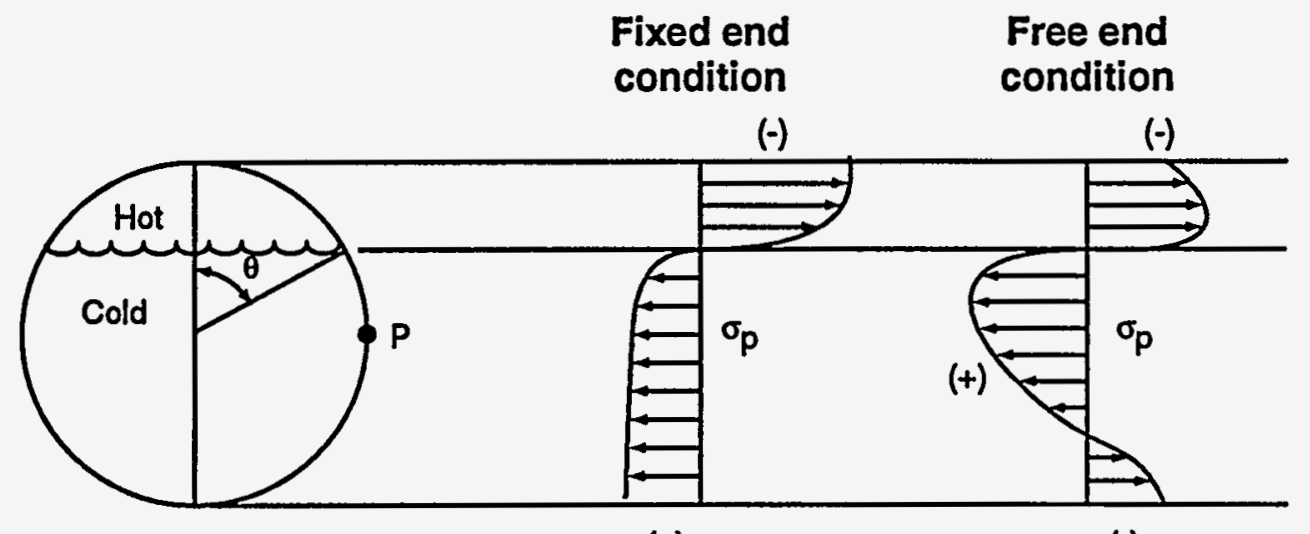

$(+)$

$(-)$

(a) High stratification level

$(-)$

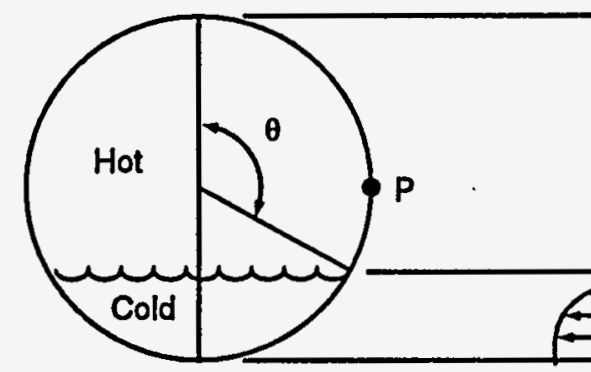

$(+)$
$(+)$

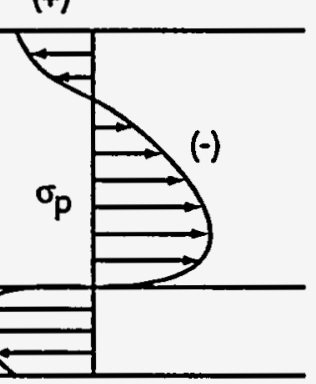

$(+)$

M950208

(b) Low stratification level

Figure 34. Distribution of axial stresses in a long horizontal feedwater pipe for two different elevations of hotand-cold coolant interface and for two different boundary conditions for the pipe ends (Shvarts et al. 1994). Copyright American Society of Mechanical Engineers; reprinted with permission.

inspection was conducted on one nozzle region; no evidence of fatigue cracking was found. ${ }^{1}$ Similar inspections are planned for future refueling outages. The licensee is reviewing several modifica-

\footnotetext{
1 V. N. Shah, Private conversation with Dave

Gonzalez, Pacific Gas and Electric, January 23, 1997.
}

tions that may inhibit crack development, as well as inhibiting the thinning of the thermal sleeves, which are discussed in Section 6.4.2. Auxiliary feedwater cycles are being monitored at both units by online fatigue monitoring. 


\subsubsection{San Onofre Unit 3}

San Onofre Units 2 and 3 are 2-loop, System 80, Combustion Engineering PWRs. In this design, a safe end is welded to the nozzle in the shop, and a field weld connects the safe end to a 45-degree elbow, as shown in Figure 35. This elbow is the terminus of the feedwater piping, and it is welded to another 45-degree elbow at its other end. A counterbore has been machined into the safe-endto-elbow weld area. The auxiliary feedwater inlet connects to the main feedwater system upstream of the two 45-degree elbows.
Although no instances of feedwater nozzle cracking had been reported on Combustion Engineering plants during the previous 10 years (since the Maine Yankee cracking), the nozzles and adjacent piping were inspected at San Onofre Units 2 and 3 in response to Information Notice 93-20 (Mostafa and Ramsey 1994). A review of the inspection data shows that no indications had been recorded, though there were evaluations of areas characterized as geometry or geometric configuration, which is allowed by ASME Section $\mathrm{XI}$.

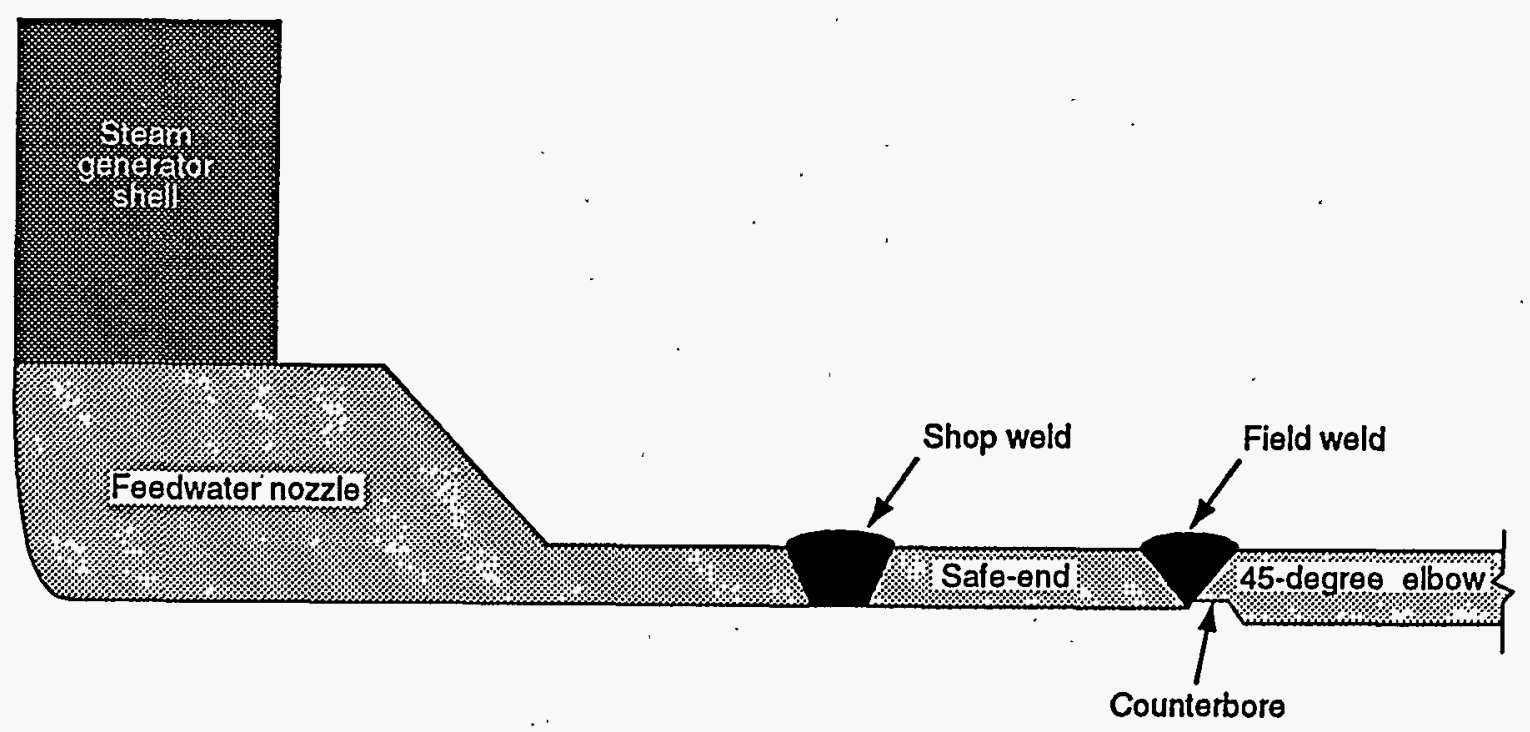

M96 0328

Figure 35. San Onofre Units 2 and 3 feedwater nozzle region (Mostafa and Ramsey 1994). Courtesy of E. Regala, Southern California Edison. 
Past History. Unit 2 began hot functional testing in 1982 and began commercial operation in 1983. The corresponding dates for Unit 3 were 1 year later. These two plants were classified by Bulletin $79-13$ as designated applicants for operating licenses, and inspections of their feedwater nozzles and piping were requested in Revision 1 to the Bulletin. No indications were found.

1993 Cracking Incident. The steam generators were inspected at San Onofre Units 2 and 3 in response to Information Notice 93-20. The inspections found no indications on Unit 2. However, during the Unit 3, Cycle 7, refueling outage, several indications were found. The UT examination detected indications at approximately the 3 and 9 o'clock positions on the safe end of one of the nozzles. These indications were initially characterized as approximately $3.8-\mathrm{mm}(0.150$-in.) deep and 137-mm (5.4-in.) or 104-mm (4.1-in.) long.

The inspection was conducted using an automated UT device (Introspect/98 Volumetric Inspection System, a 45-degree shear wave transducer), which scans the test region from two different planes. A computer processed the data, providing a threedimensional evaluation of the area, enhancing the ability to determine the size and nature of any defects (Mostafa and Ramsey 1994). This method is specifically tailored to examine crack-like reflectors originating on the inside nozzle surface.

Metallographic Evaluation of Cracking - The affected areas of both nozzle safe ends were cut out for examination. Magnetic particle tests on the safe end of one nozzle revealed numerous surface indications approximately $0.025-$ to $0.051-\mathrm{mm}(0.001$ - to 0.002 -in.) deep, extending 360 degrees around the safe end inside surface over a band about $16-\mathrm{mm}(0.625$-in.) wide. Optical micrographs of the affected area revealed very shallow cracking about $0.038-\mathrm{mm}(0.0015$-in.) deep, which is about 100 times smaller than was indicated by the initial UT examination.
X-ray spectroscopy was performed on the oxidefilled cracks and confirmed that there were numerous manganese sulfide inclusions in the areas associated with the cracks. Fluorescent magnetic particle testing of the other steam generator nozzle safe end revealed numerous linear indications of similar shallow depths. These were removed by buffing and did not require grinding.

A magnetic particle test of the weld preparation area of the elbow revealed a $216-\mathrm{mm}$ (8.5-in.) long linear indication in the counterbore region at the 9 o'clock position, outside the weld zone. Further examination with the fluorescent magnetic particle test revealed that the indication extended 360 degrees around the inside diameter of the elbow. Metallographic examination revealed an oxidized transgranular crack 0.56-mm (0.022-in.) deep. Striations on the crack surface indicate that the crack had experienced 2,235 cycles. Previous UT examination of this area showed an indication that had been evaluated as a geometric discontinuity. Examination of the other steam generator elbow revealed a similar 360-degree linear indication with a maximum depth of $3.8 \mathrm{~mm}(0.150 \mathrm{in}$.) at the 9 o'clock position. A metallographic examination revealed multiple cracking, with large sulfide (manganese and iron) inclusions in the base metal matrix, with significanthigh-temperature oxidation indicative of an old crack. The depth was approximately $0.61-\mathrm{mm}$ (0.024-in.). A few aluminum oxide inclusions were also found.

Root Cause Analysis-Based on the metallographic evaluation, the root cause of the cracking was determined to be stratified flow from on-off auxiliary feedwater operation during Modes 2 and 3 operations, similar to the other incidents of cracking. The cracking may have initiated at sulfide inclusions in the material.

During the first several years of plant operation, the auxiliary feedwater system's control valves vibrated at low flow rates, so the plant operators were required to feed at $950 \mathrm{l} / \mathrm{min}(250 \mathrm{gpm})$ or greater flow rates, or not at all, resulting in on-off 
cycles of auxiliary feedwater addition during Modes 2 and 3 operation. The cycle began with raising the steam generator water level by adding auxiliary feedwater. While the incoming cold feedwater was being heated by the hot primary coolant, the steam flow from the steam generator was almost completely stopped because of the lower secondary pressure. The auxiliary feedwater flow was stopped once the steam generator water level reached the required elevation. Secondary pressure built up as the water in the steam generator heated up and steaming took place. Steam was released through the atmospheric dump valves, the steam bypass control valves, or the main steam line drains, so that the secondary pressure was maintained at $1000 \mathrm{psi}$. As a result, the steam generator water level decreased and the cycle was repeated with another addition of cold auxiliary feedwater. The plant staff has estimated that 1,494 cycles $(9$ cycles/ day for 166 days) for Unit 2 and 1,089 cycles ( 9 cycles/day for 121 days) for Unit 3 occurred before modifications were made, respectively, in 1986 and 1985 to allow throttling of the auxiliary feedwater control valves (Martin et al. 1990).

The modifications consisted of altering the control logic to allow adjustments in the auxiliary feedwater flow to match the makeup requirements. The fluctuations in the flow rate were reduced by introducing the cold feedwater at a uniform rate between about 380 to $950 \mathrm{l} / \mathrm{min}$ (100 to $250 \mathrm{gpm}$ ) to maintain the steam generator water level.

Stratified flow will develop in the feedwater nozzle and feedring if the flow rate to each steam generator is less than about $1500 \mathrm{l} / \mathrm{min}(400 \mathrm{gpm})$. Thus, there will be only one such stratification cycle upon going to hot standby with the present operation, whereas there were approximately 9 cycles/day during the operation before the modifications were made in Units 2 and 3.

Repair and Mitigation. The cracks were repaired by excavation of the flaws and weld repair of both 45-degree elbow areas. The inservice inspection programs for both Units 2 and 3 were augmented to require automatic UT of the nozzle areas, including the safe ends and the 45-degree elbows. The ability to scan the flaw area and differentiate between flaws and the reflection from the counterbore is inhibited by the crown of the safe-end-to-elbow weld when scanning upstream. The counterbore itself gives such a large reflection that it masks small indications when scanned downstream. The weld crowns were ground down to enhance UT detection in this area. In addition, the process for disposing indications as geometric reflectors has been revised to require a more detailed justification and review.

The auxiliary feedwater system draws from the condensate storage tank, on which a nitrogen gas blanket system has been installed to prevent oxygen introduction. However, concerns with respect to the operation of this nitrogen system in a confined environment (there was a personnel safety hazard from leaking valves) have precluded its routine use during recent fuel cycles.

\subsubsection{Other PWRs}

In June 1992, prompted by the Sequoyah incident, radiographic examinations of a feedwater inlet nozzle were performed at Salem Unit 1, a 4-loop Westinghouse PWR. The examinations showed that the nozzle weld had a number of unacceptable linear indications (PSE\&G 1992). Radiographic examination of the second weld, a pipe-to-pipe weld, revealed no unacceptable indications. Results of volumetric examinations of two other steam generator feedwater nozzle welds indicated that the expander fittings had linear indications on both the nozzle-to-expander and expander-toelbow welds. No unacceptable indications were found in the other welds. There was visual observation of wall thinning in the thermal sleeve, resulting in larger-than-design gaps between the sleeve and the nozzle on two steam generators. Minor pitting and metal loss in the area immediately upstream of the thermal sleeve were found in another nozzle. No degradation had been previously observed in the area since the 1979-80 repairs.

The area was examined by UT, visual inspection, and liquid penetrant methods. New reducing spool pieces were installed in all four steam generators, 
the indications were removed by excavation and blending with the surrounding area. The deepest excavation was $2.1 \mathrm{~mm}(0.083 \mathrm{in}$.). The licensee planned to examine the repair area at the next refueling outage. Similar examinations on Salem Unit 2 revealed no unacceptable indications.

One steam generator nozzle at the Haddam Neck plant (Westinghouse 4-loop) was inspected during the 1993 refueling outage. RT showed two circumferential cracks $648-\mathrm{mm}$ (25.5-in.) and 44.5-mm (1.75-in.) long, $38 \mathrm{~mm}$ (1.5 in.) from the weld centerline in the nozzle base metal (McBrearty 1993). The nozzles had been examined in 1979-80 in response to Bulletin 7913. The weld areas of the other three steam generators were subsequently examined. Circumferential cracks were detected in two other nozzles, but the fourth one appeared to be free of defects. All defects were located in the lower 180degree portion of the nozzles. The radiography results from the 1979-80 inspection were reviewed, and it was determined that the 648-mm (25.5-in.) long crack appeared previously, but had grown longer by about $114 \mathrm{~mm}$ ( $4.5 \mathrm{in}$.). To gain access to the defects, the three elbows were removed. Using the tip diffraction UT method, the estimated crack depths for the three affected steam generators were as follows: $6.4,4.8$, and $3.2 \mathrm{~mm}(1 / 4,3 / 16$, $1 / 8$ in.). The cracks were removed by grinding, and their removal was verified by radiography.

\subsubsection{Non-US Plants}

No leakage has occurred nor cracking detected by radiography in the French steam generators (Westinghouse-type PWRs). ${ }^{1}$ However, magnetic particle inspections and crack micrography using a scanning electron microscope were carried out on samples removed from several steam generators that were being replaced. Small fatigue cracks were observed in the weld bead to heat-affected zone vicinity. UT is currently being evaluated as an alternate inspection method. New and replacement steam generators have a separate auxiliary

1 Information provided by the corresponding country via OECD Nuclear Energy Agency. feedwater nozzle and an antistratification device in the main feedwater nozzle.

Indications have been found in the steam generator feedwater nozzles of a Belgian PWR since 1985 (Westinghouse Model 44). Despite repair by grinding [crack depth less than 0.5-mm (0.02-in.)] the cracking recurred in subsequent annual inspections. ${ }^{1}$ The ultrasonic inservice inspection method in accordance with ASME Section XI was used. Water hammer damage to thermal sleeves was also found, and the thermal sleeves were replaced.

After Bulletin 79-13 was issued, cracking was found in the feedwater nozzle-to-pipe weld area of two Swiss PWRs. ${ }^{1}$ All four welds showed extensive circumferential fatigue cracking, originating at the inside and generally less than 2-mm (0.08-in.) deep. However, at one location the crack depth was two-thirds through the $20-\mathrm{mm}$ $(\sim 0.8$-in.) thick wall. Small fatigue cracks were also found in the base metal. All four nozzles were replaced, and auxiliary feedwater was routed directly to the steam generators through separate nozzles. At least some of these steam generators have been replaced with new steam generators designed by Framatome.

In some German steam generators designed by Siemens/KWU, cracks have been detected both in the pipe-to-nozzle welds and the thermal sleeve-tonozzle welds at the upstream end of the thermal sleeve. The damaged sections were replaced with a new design that includes a transition piece, so that there are now two welds instead of one. Other mitigation actions taken by Siemens/KWU are: ${ }^{2}$

- Installation of a destratification pot on the feedwater inlet inside the steam generator,

- Distribution of auxiliary feedwater through a spraying device, located in the feedwater pipe upstream of the feedwater nozzle, which mixes the cold feedwater with the hot water present in the horizontal pipe,

2 Information received from P.-J. Meyer, Siemens/KWU. 
- Installation of a recirculation loop to $\mathrm{mix}$ blowdown flow back into the feedwater line upstream of the feedwater nozzle,

- Procedural changes to allow continuous feeding to reduce the number of auxiliary feedwater actuations, and

- New steam generators designed with a destratification loop (see Section 9.1).

There have been no reports of cracking in Japanese PWR main feedwater piping since a single incident in 1974 because heated feedwater is supplied to steam generators at plant startup time. The feedwater is heated by the feedwater heaters in the deaerator. No cracking has been found at the feedwater nozzles of Finnish or Dutch PWRs.

\subsection{Flow-Accelerated Corrosion}

Flow-accelerated corrosion has damaged both large- and small-diameter feedwater piping, and feedrings and J-tubes in the steam generators. Some of the events associated with this damage are discussed here. Flow-accelerated corrosion depends on several parameters, including water chemistry $(\mathrm{pH})$, flow velocity, geometry, temperature, and materials. Most of these parameters have been identified for each event. The leading edges of the thermal sleeves have experienced thinning possibly caused by flowaccelerated corrosion and are also discussed here. Section 6.4 .1 briefly describes the field experience related to flow-accelerated corrosion of the feedwater piping, particularly the area inside containment. The field experience involving flowaccelerated corrosion of feedrings, J-tubes, and thermal sleeves in Diablo Canyon Units 1 and 2, San Onofre Units 2 and 3, and Arkansas Nuclear One Unit 2 is discussed in Section 6.4.2. Relevant experience associated with non-US PWR and CANDU plants is discussed in Section 6.4.3.

\subsubsection{Feedwater Piping}

Flow-accelerated corrosion caused the rupture of the feedwater piping outside the containment at both the Trojan plant in 1985 (Stoller 1985) and
Surry Unit 2 in 1986 (Virginia Power 1987). A pressure pulse caused the ultimate rupture of feedwater piping already significantly degraded by flow-accelerated corrosion at both plants. In neither the Trojan nor Surry case was there a leak or any other warning signs indicating incipient failure. As there had been little or no inservice inspection of the majority of the feedwater system piping at these plants, because such inspections were not required by Section XI of the ASME Code, the extent of wall thinning was not known before the ruptures occurred. This situation has changed, and all U.S. utilities are now inspecting their feedwater piping. The Trojan and Surry Unit 2 failure events are discussed in the next few paragraphs.

A main feedwater isolation following a turbine trip at the Trojan plant produced a pressure pulse that reached a maximum total pressure of approximately 6.0 MPa (875 psig) in the heater drain and feedwater system (Stoller 1985). The pressure surge ruptured a $368-\mathrm{mm}$ (14.5-in.) diameter section of SA-106 Grade B carbon steel pipe in the feedwater heater drain pump discharge piping and released a steam-water mixture into the turbine building. The system flow velocity was 6.1 to 7.3 $\mathrm{m} / \mathrm{s}$ (20 to $24 \mathrm{ft} / \mathrm{s}$ ), and the normal operating pressure and temperature at the time of the break were about $3.1 \mathrm{MPa}\left(450 \mathrm{psig}\right.$ ) and $177^{\circ} \mathrm{C}$ $\left(350^{\circ} \mathrm{F}\right)$, respectively. The ruptured portion of the piping section had been thinned from a nominal thickness of 9.5 to about $2.5 \mathrm{~mm}$ ( 0.375 to about $0.098 \mathrm{in}$.). Some of the thinning may have occurred during rupture. One worker received firstand second-degree burns from the high-temperature fluid. Before this rupture, it was believed that only piping carrying two-phase fluid was susceptible to flow-accelerated corrosion and was, therefore, inspected in service. Because the ruptured drain pipe carried single-phase fluid, it was not inspected. As a result of this failure, the entire secondary system of the Trojan plant was evaluated to identify the sites susceptible to flowaccelerated corrosion, and then a sample of the sites was included in the inspection program and subsequently inspected by ultrasonic examination. Repair and replacement of the damaged sections of piping were performed as necessary. 
A main steam isolation valve failed closed at Surry Unit 2 in December, 1986, and the resulting increased pressure in the steam generator collapsed the voids in the water. This caused the system pressure to surge beyond the normal operating pressure and led to a catastrophic failure of a 90 degree carbon steel (SA-234 Grade WPB) elbow in the suction line to the main feed pump, as shown in Figure 36. The diameter of the elbow was $460 \mathrm{~mm}$ (18 in.), and the design thickness was
$13 \mathrm{~mm}(0.5$-in.). The reactor was at full power and the feedwater was single phase, with a flow velocity of about $4.3 \mathrm{~m} / \mathrm{s}(14 \mathrm{ft} / \mathrm{s})$, a pH level in the range of 8.8 to 9.2 , an oxygen content of about $4 \mathrm{ppb}$, and a coolant temperature and pressure of approximately $188^{\circ} \mathrm{C}\left(370^{\circ} \mathrm{F}\right)$ and $3.1 \mathrm{MPa}$ (450 psig), respectively. Ammonia was used for the feedwater treatment. The examination of the ruptured elbow showed that the wall thinning was relatively uniform except in some local areas.

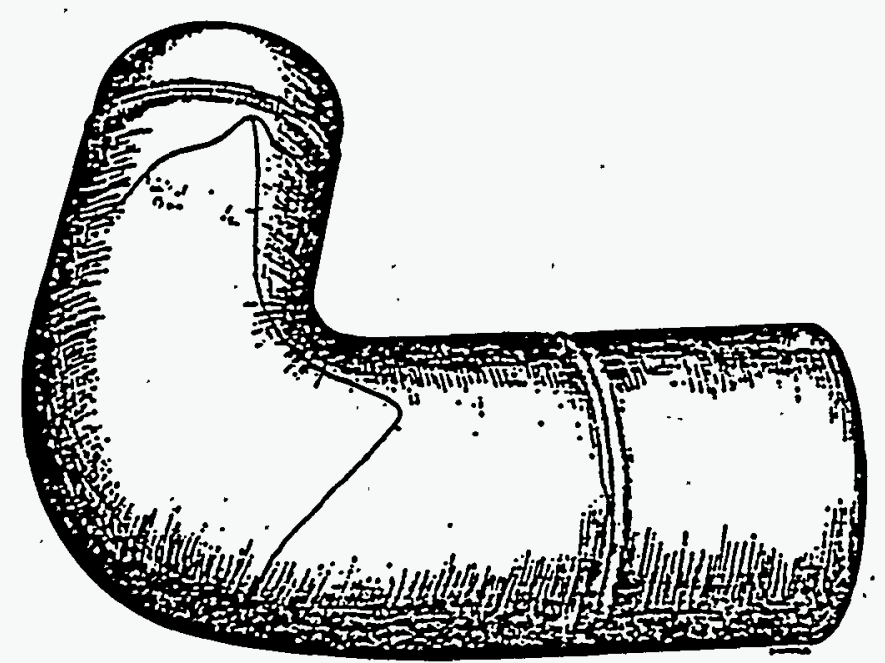

(a) Rupture lines in intact pipe.

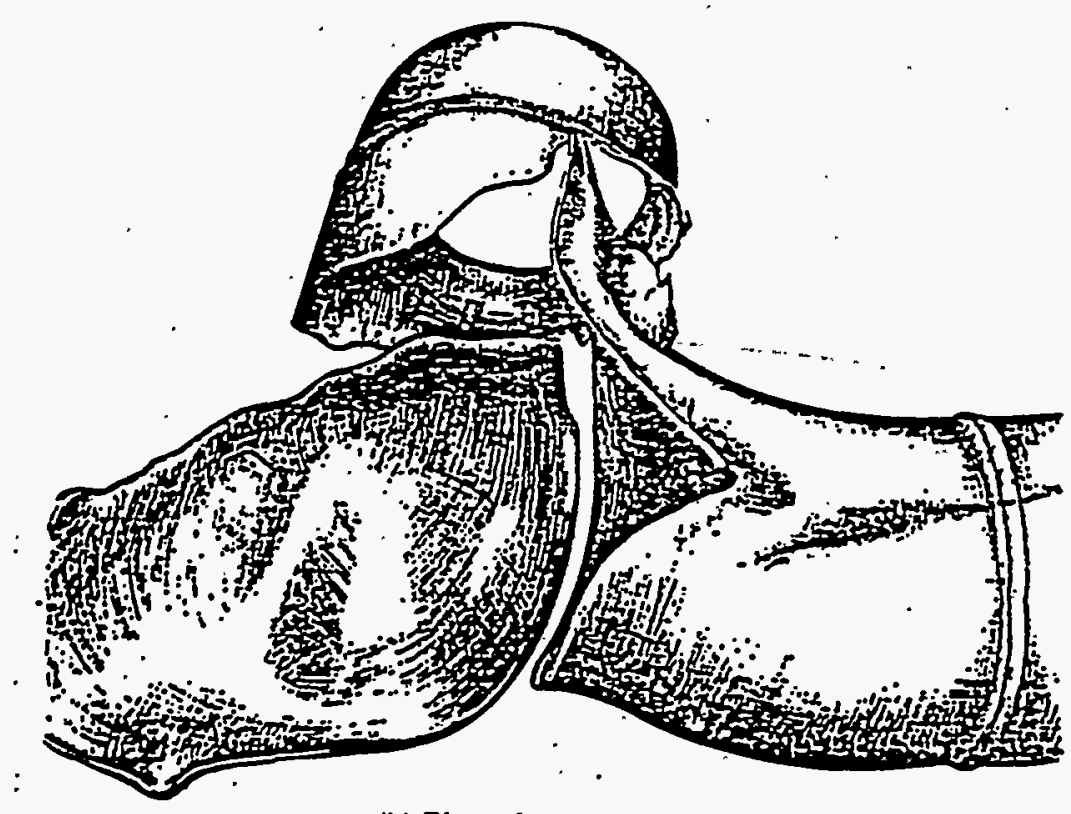

(b) Plpe after rupture.

Figure 36. Surry feedwater pipe rupture caused by flow-accelerated corrosion (Jonas 1988). 
The wall thickness of the elbow was reduced from a nominal $13 \mathrm{~mm}(0.5 \mathrm{in}$.) to $0.38-$ to $1.22-\mathrm{mm}$ (0.015- to 0.048-in.) in small local areas and to 2.3 mm (0.09 in.) in larger areas (Czajkowski 1987, Virginia Power 1987). Eight workers were burned by flashing feedwater, four of whom subsequently died. The flashing feedwater interacted with and disrupted the fire protection, security, and electrical distribution systems (USNRC 1988b).

As a result of the Surry accident, the NRC staff asked that all utilities with operating nuclear power plants inspect their high-energy carbon steel piping (USNRC 1987a). The degraded components, fittings, and straight runs in the feedwater-condensate systems identified in that inspection and reported to the NRC are listed in Table 7 (USNRC 1988a). A summary of the inspection programs and inspection results has been compiled by EPRI (Mattu et al. 1988).

New piping was installed at several locations in the Surry-2 feedwater system as a result of the pipe break. During the September 1988 outage, an elbow (installed in 1987) on the suction side of one of the main feedwater pumps was found to have lost $20 \%$ of its $13-\mathrm{mm}(0.5$-in.) thick wall in 1.2 years. The NRC preliminarily concluded that this abnormally high rate of wall thinning may have coincided with a reduction in feedwater dissolved oxygen concentration (USNRC 1988b). However, Virginia Power disagrees that the oxygen content was a major contributor. One explanation is that the accelerated thinning could have been - aggravated by feedwater flowing into the steam generators that bypassed the feedwater heaters. This would have reduced the water temperature from its normal $190^{\circ} \mathrm{C}\left(370^{\circ} \mathrm{F}\right)$ to about $150^{\circ} \mathrm{C}$ $\left(300^{\circ} \mathrm{F}\right)$ (Sperber 1988). Later in the September 1988 outage, Virginia Power replaced a total of 125 piping segments with steel piping containing $2.5 \mathrm{wt} \%$ chromium.

The ruptures at Trojan in 1985 and Surry Unit 2 in 1986 were located outside the containment and upstream of the last check valve before the feedwater enters the steam generator. In contrast, there has also been evidence of flow-accelerated corrosion in the safety-related portion of the feedwater piping inside the containment.
However, in one instance, it was later found that certain damage was not caused by flow-accelerated corrosion. In the June 1987 outage at the Trojan plant, significant flow-accelerated corrosioninduced wall thinning of two safety-related portions of the feedwater piping inside the containment was initially reported. The pipe wall thickness would have reached the minimum thickness required by the design code during the next refueling cycle. The wall thinning was in a horizontal and a vertical portion of the piping not considered susceptible to flow-accelerated corrosion damage and not included in the inspection program, because these portions were at least seven pipe diameters away from an elbow or any other fittings that could cause turbulence (USNRC 1987a). However, after further analysis, the plant operator, Portland General Electric, determined that the damage to these horizontal and vertical portions of the piping was minor and judged not caused by flow-accelerated corrosion but rather from an initial manufacturing defect. ${ }^{1}$ No other utility has reported flow-accelerated corrosion damage in straight piping away from discontinuities.

Further inspection of all the high-energy carbon steel piping at Trojan revealed wall thinning at about 30 additional sites, 10 of which were in the safety-related portion of the feedwater system, whereas the remaining were in the nonsafetyrelated piping. As a result, elbows and straight portions of piping at several of these sites were replaced. High flow velocity $[6.9 \mathrm{~m} / \mathrm{s}(22.6 \mathrm{ft} / \mathrm{s})]$ combined with other operating factors $[4 \mathrm{ppb}$ oxygen content, $\mathrm{pH}$ of 9.0 , and an operating temperature of $\left.230^{\circ} \mathrm{C}\left(445^{\circ} \mathrm{F}\right)\right] \mathrm{might}$ be the cause of the thinning. Failure analysis indicated that flow-accelerated corrosion coupled with cavitation caused by severe flow conditions at the pump discharge elbows caused the wall thinning at Trojan (Wu 1989).

\footnotetext{
1 Chexal, B. 1987. "EPRI CHEC Computer Program," Summary Report of the First User Group Meeting for the EPRI CHEC Computer Program, St. Louis, Missouri, September 22.
} 
Table 7. PWR plants with pipe wall thinning in the feedwater-condensate systems (USNRC 1988a).

\begin{tabular}{|c|c|c|c|}
\hline Plant & Unit & $\begin{array}{l}\text { Commercial } \\
\text { operation }\end{array}$ & $\begin{array}{l}\text { Degraded components } \\
\text { (fittings, straight runs) }\end{array}$ \\
\hline Arkansas Nuclear One & 1 & August 1974 & Elbows, drain pump discharge piping \\
\hline Arkansas Nuclear One & 2 & December 1978 & Undefined \\
\hline Calvert Cliffs & 1 & October 1974 & Elbows, reducers, straight runs \\
\hline Calvert Cliffs & 2 & November 1976 & Elbows, reducers, straight runs \\
\hline Callaway & - & October 1984 & Recirculation line elbows \\
\hline Diablo Canyon & 1 & April 1984 & Elbows, straight runs \\
\hline Diablo Canyon & 2 & August 1985 & Elbows, $\mathrm{Y}$ \\
\hline D.C. Cook & 2 & March 1978 & Elbows \\
\hline Fort Calhoun & - & August 1973 & Elbows, straight run \\
\hline Haddam Neck & - & July 1967 & Recirculation line \\
\hline Millstone & 2 & October 1975 & Elbows, heater vent piping \\
\hline North Anna & 1 & April 1978 & Elbows, straight runs \\
\hline North Anna & 2 & June 1980 & Elbows, straight runs \\
\hline H. B. Robinson & 2 & September 1970 & Recirculation lines \\
\hline Rancho Seco & - & September 1974 & $\begin{array}{l}\text { Straight runs downstream of } \\
\text { feedwater isolation valves or main } \\
\text { feedwater pumps minimum flow valves }\end{array}$ \\
\hline San Onofre & 1 & June 1967 & Reducers, heater drain piping \\
\hline San Onofre & 2 & July 1982 & Heater drain piping \\
\hline San Onofre & 3 & August 1983 & Heater drain piping \\
\hline Salem & 1 & December 1976 & Recirculation line \\
\hline Salem & 2 & August 1980 & Recirculation line \\
\hline Shearon Harris & - & October 1986 & Recirculation line \\
\hline Surry & 1 & July 1972 & Fittings \\
\hline Surry & 2 & March 1973 & Fittings \\
\hline Sequoyah & 1 & July 1980 & Elbows, straight runs \\
\hline Sequoyah & 2 & November 1981 & Elbows \\
\hline Trojan & - & December 1975 & Elbows, reducers, straight runs \\
\hline Turkey Point & 3 & October 1972 & Feedwater pump suction line fittings \\
\hline
\end{tabular}


A potential generic problem was discovered at Catawba Unit 2 in 1991 that may affect all the Westinghouse Model D4, D5, and E steam generators in which a portion of the main feedwater is diverted to the auxiliary feedwater nozzle via the preheater bypass line, as shown in Figure 9 (Stoller 1992a, USNRC 1992). The fluid velocity in the 102-mm (4-in.) diameter preheater bypass line and the connecting auxiliary feedwater line was in the range of 9 to $11 \mathrm{~m} / \mathrm{s}(30$ to $35 \mathrm{ft} / \mathrm{s})$. The licensee detected several locations in this piping that were at or near the minimum required wall thickness. Examinations revealed that singlephase flow-accelerated corrosion had reduced the nominal $8.56-\mathrm{mm}(0.337$-in.) wall thickness to $4.70-\mathrm{mm}(0.185-\mathrm{in}$.) in only four operating cycles. This implies a flow-accelerated corrosion rate of about $1.0 \mathrm{~mm} /$ cycle $(0.04 \mathrm{in} . / \mathrm{cycle})$. If the preheater bypass line had ruptured, the break would not have been isolable and would have resulted in the steam generator coolant being

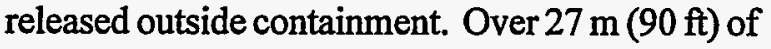
piping was replaced at Catawba Unit 2.

Recent field experience related to pipe ruptures caused by wall thinning has identified additional sites susceptible to flow-accelerated corrosion damage that were not included in the plants' monitoring programs (USNRC 1991a). This experience demonstrates that the flow-accelerated corrosion is a complex, multi-parameter phenomena, and the susceptibility of a given site cannot be determined by considering only a few parameters. Generally, the flow-accelerated corrosion monitoring programs concentrate on inspection of pipe elbows and tee fittings, the sites where local high velocities may be present. However, flow-accelerated corrosion has caused rupture at other feedwater piping sites, such as in the flange of a flow measuring device downstream of an orifice at Loviisa Unit 1 in Finland (discussed in Section 6.4.3) and in the straight portion of a pipe, located immediately downstream of a level control valve, at Surry Unit 1 and at Millstone Unit 3. Flow-accelerated corrosion has caused significant wall thinning of the feedwater control valve bypass line at both the San Onofre and Diablo Canyon plants. It was surprising to find significant wall thinning and failures of the startup feedwater system piping at both the Wolf Creek and Callaway plants because these systems are used for a very short time period during startup. Investigation of these failure showed that the cause was the flow resulting from the leaking valves on the piping (Chexal et al. 1996).

EPRI has developed the computer code CHECWORKS (Chexal-Horwitz Engineering-Corrosion Workstation) for managing flow-accelerated corrosion of nuclear power plant piping. This program has capabilities for estimating param.eters (such as local water chemistry and flow rate) that affect corrosion rates, and for predicting corrosion rates and helping to select inspection locations. The computer code is based on data from France, England, Germany, and the U.S. The code has been validated using other U.S. plant data. The comparison between the predicted results and measurements show that the code predicts the flow-accelerated corrosion rates within $\pm 50 \%$. The main sources of uncertainties are associated with the original thickness and thickness profile of the piping components, trace amounts of alloy content in the piping material, actual number of hours of operation, plant chemistry history, and discontinuities on the inside surface of the piping.

All PWR and BWR plants in the U.S. use the CHECWORKS code (or its predecessor code CHECMATE) for estimating the flow-accelerated corrosion rates. This code is also used by many fossil plants, by the U.S. Navy, and by several overseas utilities. The code has been used for identifying the sites most susceptible to flowaccelerated corrosion, prioritizing the locations that need to be inspected, estimating remaining service life for each susceptible component, and evaluating the effectiveness of different water chemistries and other mitigative actions. 


\subsubsection{Feedrings and Thermal Sleeves}

The carbon steel J-tubes and feedrings within the recirculating steam generators have also experienced significant flow-accelerated corrosioninduced wall thinning. A portion of a severely thinned J-tube may be separated from the feedring and become a loose part and cause damage to the steam generator tubes, leading to leakage of the primary coolant. Also, spray of relatively cold feedwater from a broken J-tube may be directed onto the steam generator shell, causing thermal fatigue damage.

Carbon steel J-tubes were installed in recirculating steam generators in 1975 to eliminate steam generator water hammer events. Several of these J-tubes failed because of flow-accelerated corrosion in both the U.S. and non-U.S. PWRs (Roarty 1986, Chexal et al. 1996). Therefore, licensees have replaced the original J-tubes with ones made of stainless steel or Alloy 600 . However, concerns persist that the joint design between the new J-tubes and the feedrings may have introduced geometric discontinuities on the inside surface of the feedrings. Such discontinuities could generate local feedwater turbulence at the base of the J-tube and cause flowaccelerated corrosion damage in the carbon steel feedrings (Shah and MacDonald 1993). Flowaccelerated corrosion of the feedring has been reported at the Diablo Canyon, Surry, and North Anna (Westinghouse) units. No original carbon steel feedrings have been replaced in any Westinghouse unit.

The discussion in Section 6.3 about feedwater nozzle cracking in the Salem 1 and Diablo Canyon 1 and 2 plants mentioned the thinning of the leading edge of the thermal sleeves, shown in Figure 32. Thermal sleeves at other Westinghouse (Prairie Island and Trojan) and Combustion Engineering (San Onofre and Arkansas Nuclear One Unit 2) plants have also experienced thinning. Wall thinning at this location had not been reported until recently (after 1989). The damage mechanism is believed to be flow-accelerated corrosion. In the original Westinghouse steam generators, slip-on type thermal sleeves were tightly fitted in the feedwater nozzle with approximately a $0.25-$ to $0.51-\mathrm{mm}(0.010-$ to $0.020-\mathrm{in}$.) gap between the sleeve and nozzle to permit free thermal growth in the axial direction. Because of the thinning of the leading edge, the gap between the nozzle and the sleeve increased. The increase in the gap permits increased bypass leakage of the colder feedwater into the hot steam generator coolant present near the nozzle blend radius region. Cracking in a feedwater nozzle caused by the bypass leakage has been reported at only a few PWR plants such as Indian Point 2 shown in Figure 23, but such cracking had been a major problem in BWR feedwater nozzles (Snaider 1980). In the replacement steam generators the leading edge of the thermal sleeve is welded to the feedwater nozzle. ${ }^{1}$

Diablo Canyon Units 1 and 2. Figure 5 shows a typical feedring assembly, which consists of a 406-mm (16-in.) diameter thermal sleeve, a $406 \times 406 \times 406-\mathrm{mm}$ ( $16 \times 16 \times 16-i n$.) tee fitting, two $406 \times 254-\mathrm{mm}(16 \times 10$-in.) eccentric reducers, and two 254-mm (10-in.) serpentine feedrings. All of these subcomponents were originally SA-106 Grade B or SA-105 carbon steel. The carbon steel J-tubes, installed before commercial operation began and degraded by flowaccelerated corrosion, were replaced by ones of the same design, but made of Alloy 600, during the first refueling outage. The original Alloy $600 \mathrm{~J}$ tube design is shown in Figure 37(a). The inserted end of the J-tube is recessed into the pipe wall to reduce turbulence (Thailer, Dalal, and Goyette 1995).

The feedwater treatment through the first five cycles of operation resulted in an average $\mathrm{pH}$ of 8.7 to 8.9. During the 6 th cycle, the amine was changed to ethanolamine at a $\mathrm{pH}$ of approximately 9.2.

Extensive examinations during the 6th refueling outage at Unit 1 using visual and video probe inspection of the interior of the feedring assembly revealed significant degradation of the carbon

\footnotetext{
1 The leading edge of the thermal sleeve is welded to the nozzle to minimize the possibility of water hammer. The sleeve is also welded in some German-designed steam generators.
} 


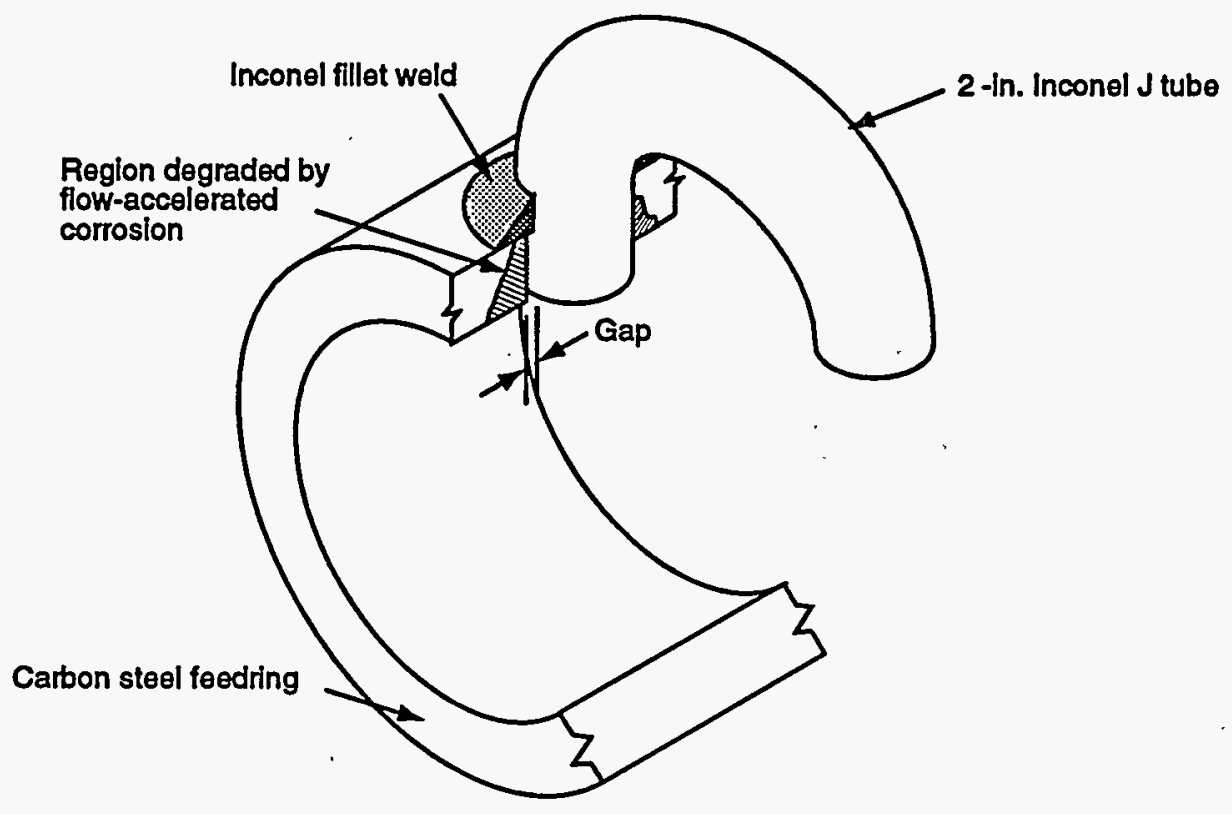

(a) Original design

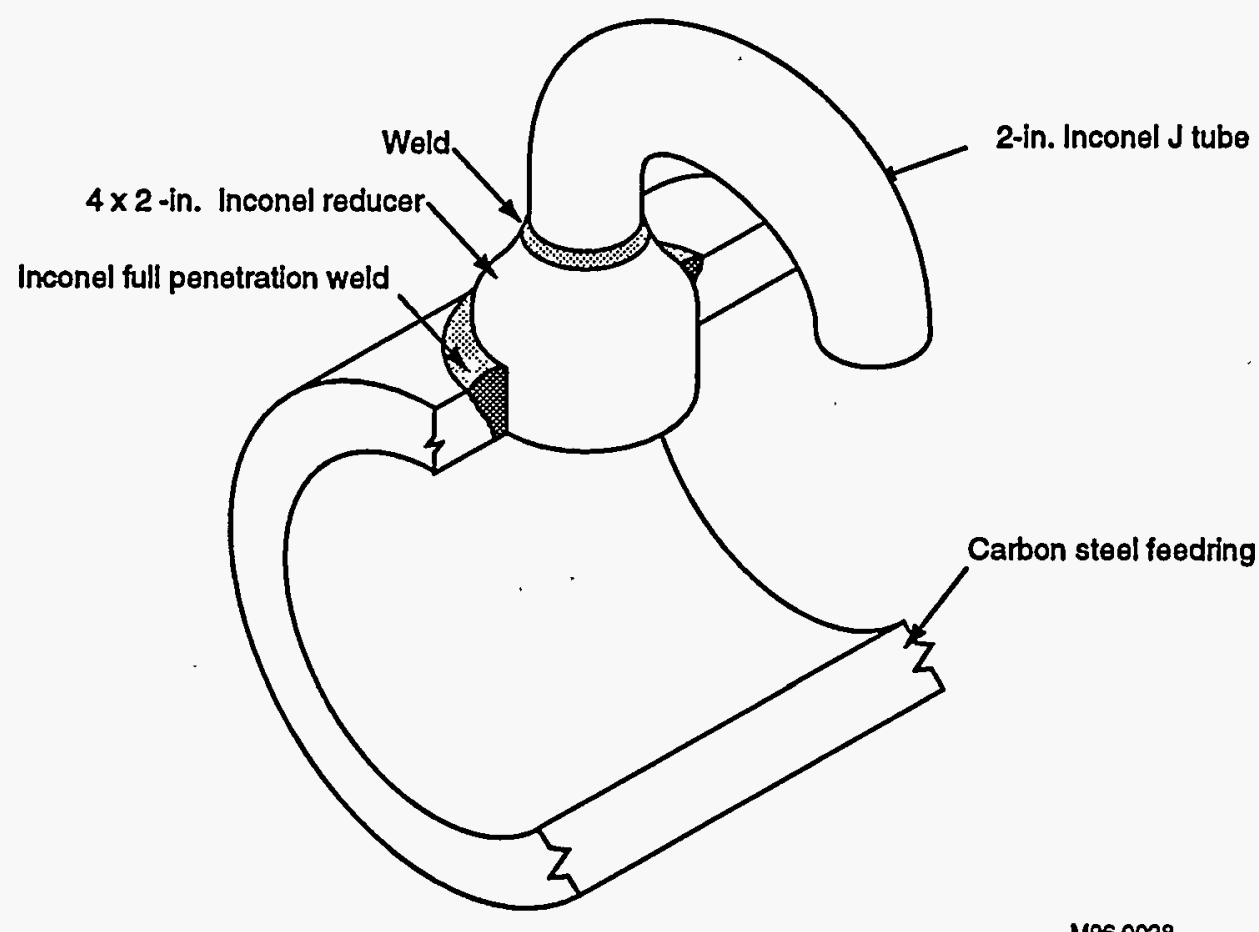

(b) Modified design

Figure 37. Changes in the Diablo Canyon J-tube design to mitigate flow-accelerated corrosion damage (Thailer, Dalal, and Goyette 1995). Copyright American Society of Mechanical Engineers; reprinted with permission. 
steel base metal surrounding the Alloy $600 \mathrm{~J}$-tubes in the tee fitting and the reducer sections of the feedring assembly. (Some Diablo Canyon feedrings have a J-tube in the reducer section, whereas others, as shown in Figure 5, do not.) The degradation was caused by flow-accelerated corrosion. Similar degradation was noted at the Diablo Canyon Unit 2 J-tube connections. However, the Alloy $600 \mathrm{~J}$-tubes were unaffected by the corrosion mechanism. The carbon steel region of the feedring surrounding the J-tubes exhibited significant degradation if the chromium content of the steel was less than $0.1 \mathrm{wt} \%$. Spectrographic analysis was used to determine the chromium content. Although the degraded region extended around the entire periphery of the $\mathrm{J}$ tubes, the magnitude and extent of the damage was greatest in regions located 90 degrees to the direction of flow in the feedring. In some cases, the damaged region extended completely through the wall to the surface of the Alloy 600 fillet weld. Seven through-wall holes ranging in size from a pin hole to about $12.7 \mathrm{~mm}(0.5 \mathrm{in}$.) across were observed adjacent to the plugs installed on the underside of the feedring, though the degradation was not as severe as that on the areas surrounding the J-tubes. This is believed to have been caused by defective welds.

Ten J-tubes in Unit 1 and eight in Unit 2 have recently been replaced with a modified design, shown in Figure 37(b). In the modified design, $102 \times 51-\mathrm{mm}$ ( $4 \times 2$-in.) Schedule 160 reducers (to reduce flow velocity) are welded to the feedring and ground flush with the feedring inside diameter (to reduce turbulence). Then the J-tubes are welded to the reducers. The J-tube length was shortened to maintain the original height above the feedring and the discharge orientation relative to the feedring. Similar damage to the carbon steel feedring at the entrance to the J-tubes was reported at Sequoyah Unit 1 in the early 1980 s and a similar repair was performed (Chexal et al. 1996).

Thermal Sleeves-The leading edges and the outside surfaces of the thermal sleeves are exposed to high velocity flow during operation.
The feedwater velocity is approximately $5 \mathrm{~m} / \mathrm{s}$ (17 ft/s) through the sleeves to the feedrings; however, a small portion of the feedwater leaks through the gaps between the thermal sleeves and the nozzles at a velocity of $6.75 \mathrm{~m} / \mathrm{s}(23 \mathrm{ft} / \mathrm{s})$. Inspection of the Unit 1 thermal sleeves showed significant degradation of the leading edges and the outside surfaces. Similar but less severe damage was observed on the Unit 2 thermal sleeves during the 5 th refueling outage.

The licensee believes that direct impingement of the feedwater onto the leading edges of the thermal sleeves and the high fluid velocities are the major contributors to the degradation. Observations of wear patterns indicate that the knife-edge appearance of the leading edges have been caused by erosion, whereas the thinning of the thermal sleeve walls has been caused by flow-accelerated corrosion damaging the outside surfaces. As a result, in one steam generator, the original 1.25 - $\mathrm{mm}(0.05$-in.) gap between the thermal sleeve and the nozzle was increased to a maximum of 5 $\mathrm{mm}(0.20 \mathrm{in}$.), and the degradation on the outside surface of the thermal sleeve extended for at least $76 \mathrm{~mm}$ ( $3 \mathrm{in}$.) from the leading edge. The degree of damage was noted to be a function of the chromium content of the base metal. ${ }^{1}$

A single-piece tuming fork forging (shown in Figure 38), sometimes referred to as a transition piece, was installed in Units 1 and 2 in 1994. The forging is made of SA-508 Class 2 low-alloy steel having 0.25 to $0.45 \mathrm{wt} \%$ chromium, which provides improved resistance to flow-accelerated corrosion. The ends of the transition piece are welded to the feedwater piping and nozzle. The downstream end of the forging supports a sealing device consisting of a spring and a piston ring installed in a groove to provide a tight seal between the forging and a thin liner installed inside the original thermal sleeve. The chromium content

\footnotetext{
1 Goyette, L., "Steam Generator Feedring Experience at Diablo Canyon Power Plant," presented at the Eleventh EPRI CHEC/CHECMATE Users Group Meeting (CHUG), Jackson Hole, WY, June 2, 1994.
} 


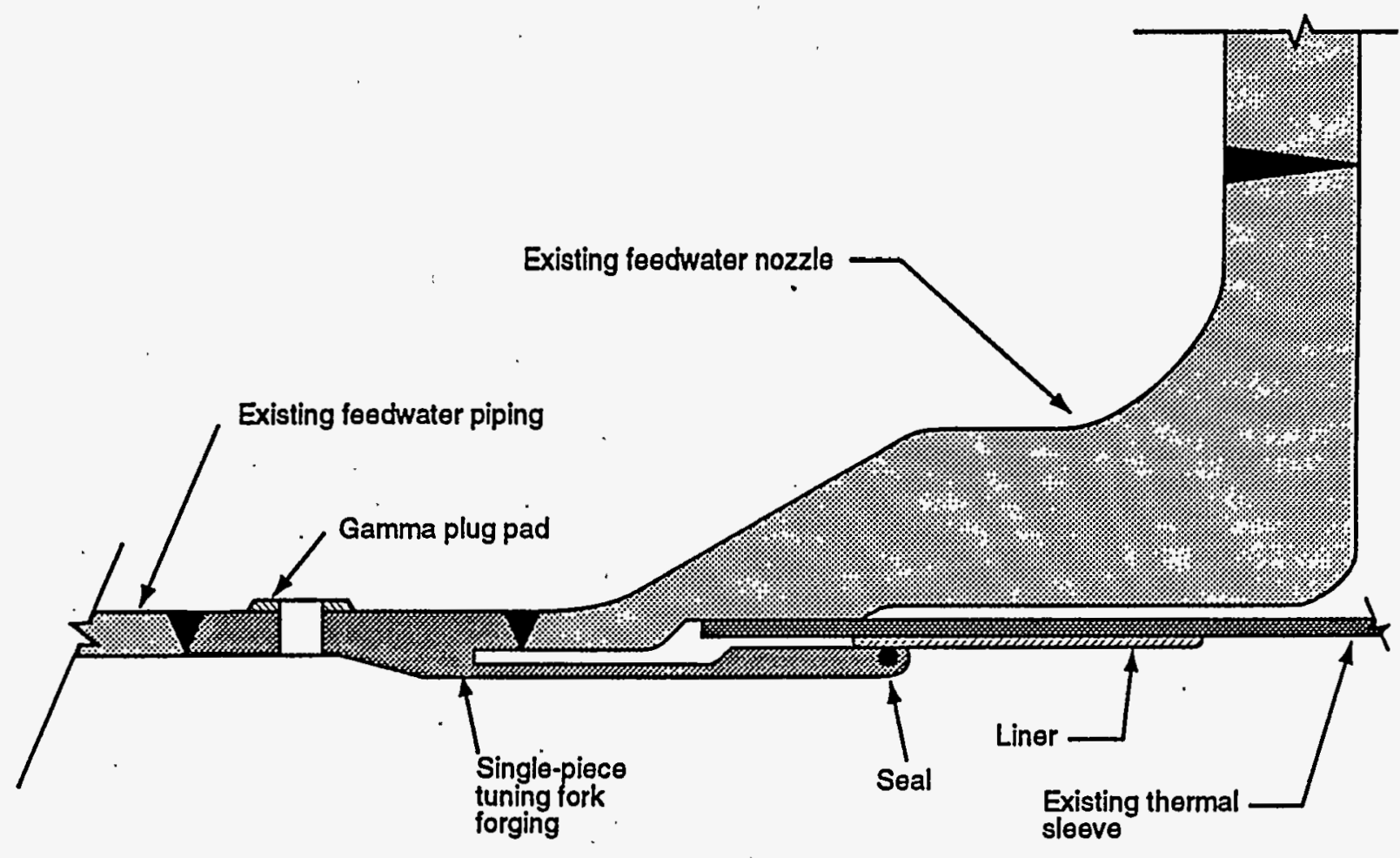

$M 960013$

Figure 38. A redesigned feedwater nozzle-to-piping connection at Diablo Canyon Units 1 and 2 (Cofie et al. 1994). A single piece forging protects the thermal sleeve from flow-accelerated corrosion damage and feedwater nozzle weld from thermal fatigue damage. Copyright American Society of Mechanical Engineers; reprinted with permission.

of the liner material was greater than $0.1 \mathrm{wt} \%$. The counterbore was eliminated, which reduces the thermal stresses and the potential for fatigue cracking at the pipe-to-nozzle junction. Thus the forging protects the leading edge of the thermal sleeve from flow-accelerated corrosion "and protects the feedwater piping and nozzle from fatigue damage.

San Onofre Unit 3. During the early part of the March 1981 startup of Unit 2, a test resulted in a partial vacuum within both halves of the feedring of one steam generator; the feedring collapsed because of the inadequate flow area of the discharge elbows (whose function is the same as that of J-tubes) and the relatively thin Schedule 40 feedring wall. The collapsed feedring was replaced in 1982 with Schedule 120 pipe. The original distribution box was left in place, along with about a $229-\mathrm{mm}$ (9-in.) section of Schedule 40 material (called a pup) welded to each side of the distribution box, as shown in Figure 14. The diameter of the discharge elbows was increased from 38 to $63 \mathrm{~mm}$ (1.5 to $3.5 \mathrm{in}$.), and tee-shaped vent assemblies were installed on the distribution box. On Unit 2 only, the feedring supports were modified, including slotting the U-bolt holes so the feedrings could move through the supports. This allowed the feedrings to move more freely in Unit 2 than in Unit 3.

In 1990 , several pieces of carbon steel debris were found on the secondary side of the tubesheet of one of the San Onofre Unit 3 plant steam generators. Further inspection of the two steam generators revealed significant material missing from the pup 
on one steam generator, surface cracks in the heataffected zone at the toe of the weld that joins the pup and distribution box, local erosion of the pups (in one case producing a through-wall penetration), wall thinning of vent pipe (caused by both erosion and flow-accelerated corrosion), missing tops of the vent tees and deformation of many of the U-bolt supports (USNRC 1991b, Martin et al. 1990). Examination of Unit 2 found no missing material from the distribution box-feed-ring junction (pups), but all the pups had cracked around the perimeter, both legs of one U-bolt were fractured, all the pups were somewhat thinned, and many of the U-bolts were stretched and deformed. None of this type of damage had been reported at other Combustion Engineering plants, which do not have pups in their designs, though Calvert Cliffs had experienced local thinning in the distribution box.

The U-bolts deformed because of excessive loads resulting from expansion-contraction of the feedring every time cold auxiliary feedwater (or cold main feedwater) was injected into the feedring. Stratified flow develops in the feedring when the flow rate into the steam generator is less than approximately $1500 \mathrm{l} / \mathrm{min}$ (400 gpm). A marked temperature change at the interface between the hot and cold fluids will persist at the pup for about $30 \mathrm{sec}$. Thermal analyses show that the fluid interface elevation would be relatively constant at about the 4 and 8 o'clock elevation. Calculations show that the feedring will bend downward as a result of the stratified flow, and will also contract and bend inward because of overall cooling.

The cracks first initiated at the 4 o'clock position at the toe of the weld that joins the distribution box to the pup. The cracks then propagated through the wall to produce very high local flow velocities as the water flowed through the crack, eroding the wall. Finally, the wall became so thin that rupture occurred and pieces were torn away by feedwater exiting the feedring.
The Schedule 40 pup material was replaced with Schedule 120 piping material, the distribution boxfeedring weld configuration was replaced with weld-o-let forgings to reduce the stress concentrations at the heat-affected zone, the vents were removed from the design, weld buildup was used to repair local thinning, the feedring supports were modified to provide greater flexibility (slotted holes enlarged), and stronger (SA-193 Grade B7M) U-bolts were used. Combustion Engineering issued CE Information Bulletin 90-04 recommending that its client utilities perform a baseline inspection during their next refueling outage to determine if wall thinning was occurring (USNRC 1991b).

The Unit 2 changes included a new distribution box made of Alloy 690, new J-tubes made of $21 / 4$ Cr-1Mo steel (P22-grade), and a pup piece made from SA-106 Grade B, Schedule 120, 305-mm (12-in.) pipe, but no material change was made for the SA-106 Grade B feedring. A monitoring program will be implemented to observe the metal thinning of the distribution box and the pups after approximately every 5 years of operation.

Arkansas Nuclear One Unit 2. Thinning of the leading edge of the thermal sleeve was found in Steam Generator A of the Arkansas Nuclear One Unit 2 in 1991, an older vintage Combustion Engineering plant (USNRC 1991d). The thinning occurred at the 12 and 7 o'clock locations, and resulted in an open gap between the sleeve and nozzle which extended along the circumference as much as $25.4-\mathrm{mm}$ (1-in.) between the 12 and 7 o'clock locations where the thermal sleeve meets the feedwater distribution box (that is, at the downstream end of the thermal sleeve). A clamp to close the gap was chosen as a temporary repair, similar to the arrangement used at the Calvert Cliffs Station in 1989. 


\subsubsection{Non-US Plants ${ }^{1}$}

Finland, Belgium, and Spain have reported flowaccelerated corrosion of feedwater lines in their PWRs, and Canada has reported similar corrosion in its CANDU reactors. The Netherlands has not reported flow-accelerated corrosion in its PWR, possibly because its feedwater piping material is low-alloy steel. However, to address the problem of postulated pipe rupture, the Netherlands is planning to replace the feedwater piping inside the containment with a very high quality piping. Japan and Switzerland have reported an absence of single-phase flow-accelerated corrosion damage in their PWR plants.

In May 1990, a feedwater pipe at Loviisa Unit 1 ruptured when the plant was operating at full power. The failure location was on the pressure side of a feedwater pump, immediately downstream of the flowmeter flange, as shown in Figure 39 . The rupture was caused by a pressure
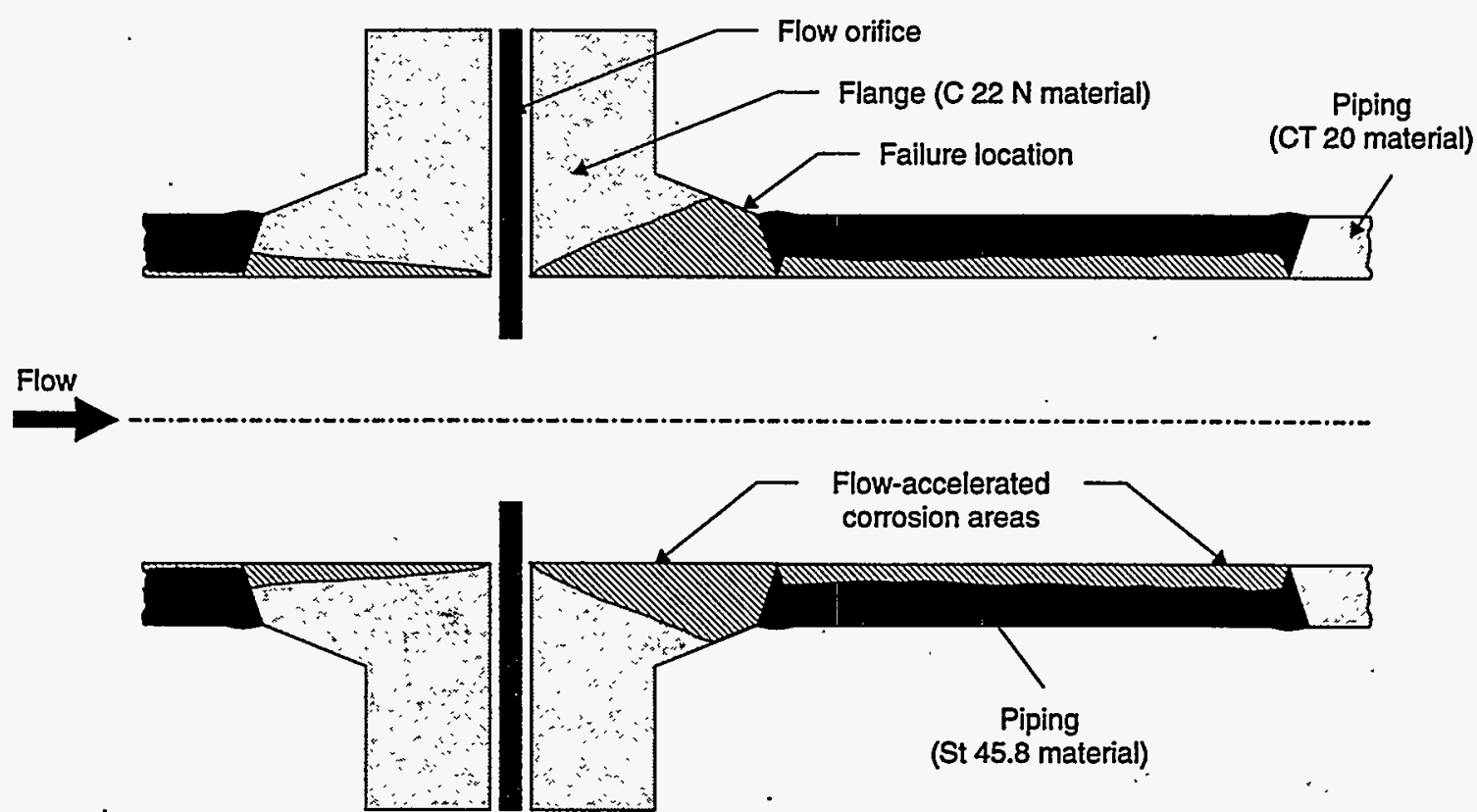

\begin{tabular}{|c|c|c|c|c|c|c|c|c|}
\hline \multirow{3}{*}{$\begin{array}{c}\text { Material } \\
\text { Type }\end{array}$} & \multicolumn{10}{|c|}{$\begin{array}{c}\mathrm{C} \\
(\%)\end{array}$} & $\begin{array}{c}\mathrm{Mn} \\
(\%)\end{array}$ & $\begin{array}{c}\mathrm{Si} \\
(\%)\end{array}$ & $\begin{array}{c}\mathrm{S} \\
(\%)\end{array}$ & $\begin{array}{c}\mathrm{P} \\
(\%)\end{array}$ & $\begin{array}{c}\mathrm{Cr} \\
(\%)\end{array}$ & $\begin{array}{c}\mathrm{Ni} \\
(\%)\end{array}$ & $\begin{array}{c}\mathrm{Cu} \\
(\%)\end{array}$ \\
\hline C 22 N & 0.18 & 0.50 & 0.32 & 0.022 & 0.012 & - & -- & - \\
St 45.8 & 0.20 & 0.89 & 0.26 & 0.018 & 0.029 & -- & - & - \\
CT 20 & 0.19 & 0.57 & 0.25 & 0.019 & 0.026 & 0.20 & 0.30 & 0.30 \\
\hline
\end{tabular}

C176.WHTr-196-01

Figure 39. Loviisa Unit 1 feedwater pipe rupture caused by flow-accelerated corrosion (USNRC 1991a).

${ }^{1}$ Information presented in this section has been provided by the corresponding country via OECD Nuclear Energy Agency. 
wave resulting from a change in the operating speed of the feedwater pump. The normal operating pressure was $7 \mathrm{MPa}(1000 \mathrm{psi})$. Investigations have indicated that significant wall thinning had taken place over the complete circumference of the flange, and its wall had thinned to $1 \mathrm{~mm}$ (0.039 in.) from the original thickness of more than $18 \mathrm{~mm}$ (0.7 in.). A $0.5-\mathrm{m}$ (20-in.) long pipe section, attached to the downstream end of the flange, had also experienced wall thinning along its entire circumference; its thickness was reduced from the original value of $18 \mathrm{~mm}(0.7 \mathrm{in}$.) to a thickness in the range of 5 to $10 \mathrm{~mm}(0.195$ to 0.390 in.).

The secondary water chemistry played an important role in causing the wall thinning; Loviisa Unit 1 used neutral water chemistry (cold $\mathrm{pH}=7$ ) with low dissolved oxygen. ${ }^{1}$ This water chemistry was used for protecting the austenitic stainless steel steam generator tubes from stress corrosion cracking, and the cooper-alloy condenser tubes from corrosion damage. Because of this failure, the utility is planning to replace the condenser tubes at both Loviisa units with tubes made of titanium or austenitic stainless steel. Then the utility will reevaluate the water chemistry. Two other reasons for the significant wall thinning include: (a) the flow orifice introduced a discontinuity on the inside surface of the piping and produced high velocities downstream of the orifice, and (b) the alloy content in the flange and the $0.5-\mathrm{m}$ long section of the pipe was low. In contrast, the piping downstream of the $0.5-\mathrm{m}$ long pipe section did not exhibit any wall thinning, possibly because it contained more alloying elements $(0.20 \mathrm{wt} \% \mathrm{Cr}, 0.30 \mathrm{wt} \% \mathrm{Ni}$, and $0.3 \mathrm{wt} \%$ $\mathrm{Cu})$. This experience is similar to that at Diablo Canyon, where the components containing more than $0.1 \mathrm{wt} \% \mathrm{Cr}$ did not experience wall thinning (USNRC 1991a, NEA 1990).

The rupture at Loviisa Unit 1 took place in the turbine building, releasing nonradioactive water and steam into the turbine building. The local damage to nearby cables and small piping was

I V.N. Shah, private communication with D. Munson, EPRI, Palo Alto, California, June 1996. significant, but no important functions were lost. The utility had an inspection program for the components exposed to single-phase flow, but only elbows and tee fittings were inspected. After the rupture, the utility inspected the flow-orifice flanges at both units and found that 9 of the 10 flanges were below the minimum thickness requirements. Unit 2 was shut down and all the damaged flanges were repaired; both units were restarted in June 1990.

A similar event occurred at Loviisa Unit 2 three years later, in May 1993, when the plant was operating at full power. The failure location was on the pressure side of a feedwater pump, immediately behind the check valve. The original thickness, which was bearing the normal operating pressure of $7 \mathrm{MPa}(1,000 \mathrm{psi})$, was reduced by flow-accelerated corrosion to $1.5 \mathrm{~mm}(0.06 \mathrm{in}$.). The rupture occurred when the feedwater pump was not in operation but was being warmed for startup by recirculation. The leak through the ruptured piping caused local damage to nearby electrical equipment and instrumentation, but again, no important functions were lost. The plant resumed operation after necessary repairs were made (NEA 1993).

In September 1987, a condensate line from a moisture separator-reheater at Doel Unit 1 in Belgium ruptured, causing a second degree burn to an operator. As a result, a more comprehensive inspection program for monitoring wall thinning of feedwater, steam, and condensate system piping was developed. This inspection program is described in Section 8.4.2.

Flow-accelerated corrosion has caused several failures of the feedwater piping in Spanish nuclear power plants. One example was a rupture of the suction side of the main feedwater piping in the Garona nuclear power plant, a BWR plant, in 1989. The primary cause of this failure was a low oxygen content $(\sim 10 \mathrm{ppb}){ }^{2}$ In other cases, the most affected areas were located near the pump discharge and control valves in the feedwater

2 V.N. Shah, private communication with D. Munson, EPRI, Palo Alto, California, June 1996. 
system. Many carbon steel pipes and fittings that were susceptible to flow-accelerated corrosion were replaced with low-alloy steel components.

Flow-accelerated corrosion has also caused significant wall thinning of reducers located downstream of the main boiler level control valves in CANDU reactors at the Bruce B site in Canada. In 1990, significant wall thinning was detected at the small end of the outlet reducer in Unit 5. The thickness was reduced from $96 \%$ in 1987 to $65 \%$ of the nominal thickness. The code-allowed thickness was $74 \%$ of the nominal thickness. Inspection of all other similar reducers in Unit 5, except the spare ones, revealed that the wall thickness was reduced below the minimum allowable. The wall thinning was uniform along the circumference. Inspection of the reducers in Unit 6, which was placed in service at about the same time as Unit 5 , did not reveal any significant wall thinning. However, inspection of the reducers in Units 7 and 8 , which were placed in service after Unit 5 and expected to be in better condition, revealed significant wall thinning, which necessitated the replacement of the reducers at those units. A possible reason is the high flow velocity through the boiler level control valve and the outlet reducer. Also, the laboratory analysis of the samples removed from the reducers showed that the chromium content in the reducers from Unit 6 was about four times higher than that in the reducers in Unit 5, a possible explanation for no wall thinning of the reducers in Unit 6.

No country besides the U.S. has reported any wall thinning of feedrings, J-tubes, or thermal sleeves in response to our questions. However, wall-thinning of carbon steel J-tubes had occurred in several nonU.S. PWRs, and they were replaced typically with ones made from nickel-based materials. France has reported that their inspection techniques are not sufficiently advanced to detect thinning of the thermal sleeve, whose design is somewhat different than the one in a typical Westinghouse plant. The feedwater pipe includes a monolithic thermal sleeve that mates with a sleeve fastened to the feedring. The connection between the two sleeves allows them to slide freely, relative to each other, but the details of the connection are not available.
The leading edge of the sleeve attached to the feedring could possibly experience wall thinning. It is also not known whether leakage can take place through the connection; such leakage could pose potential concerns for water hammer and for fatigue damage to the feedwater nozzle bore and blend radius.

\subsection{Steam Generator Water Hammer Damage}

The portion of the main and auxiliary feedwater piping adjacent to the feedwater nozzle (shown in Figure 1) can be affected by a steam generator water hammer, which is caused by the collapse of a steam bubble. Steam generator water hammers have typically occurred in several U.S. and European PWR plants with top-feed steam generators following uncovery of the feedrings. In addition, collapse of steam bubbles has caused a few water hammers in auxiliary feedwater lines of both top-feed and preheat steam generators. The steam generator water hammer phenomenon is described next. Then, the field experience associated with both the main and the auxiliary feedwater systems of the top-feed steam generators is presented and selected water hammer events are briefly described. Finally, the field experience associated with the auxiliary feedwater lines for both the top-feed and preheat steam generators is presented.

\subsubsection{Steam Generator Water Hammer Phenomenon}

The sequence of events presented in Figure 40 has generally been accepted as a cause for steam generator water hammer occurrences (Han and Anderson 1982). This mechanism has been demonstrated with experiments reported by Block et al. (1976). Initially, the upper portions of the drained feedring and the horizontal length of the adjacent feedwater piping are filled with steam. When auxiliary feedwater flow, which is usually highly subcooled, is resumed, it enters the horizontal run of the feedwater piping into the feedring and flows under the steam blanket as shown in Figure 40(a). If the flow rate is high, interaction forces between the steam and water can 


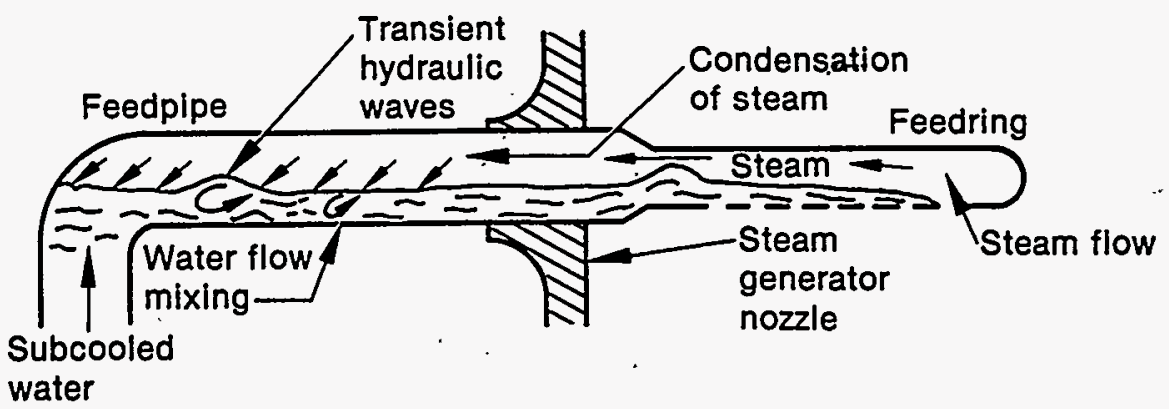

(a) Possible Steam-Water Mixing Phenomena in the Feed System

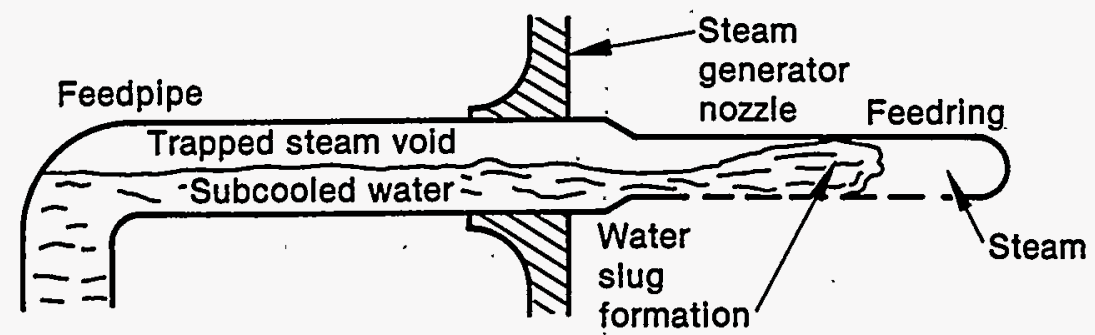

(b) Possible Trapping of a Steam Void

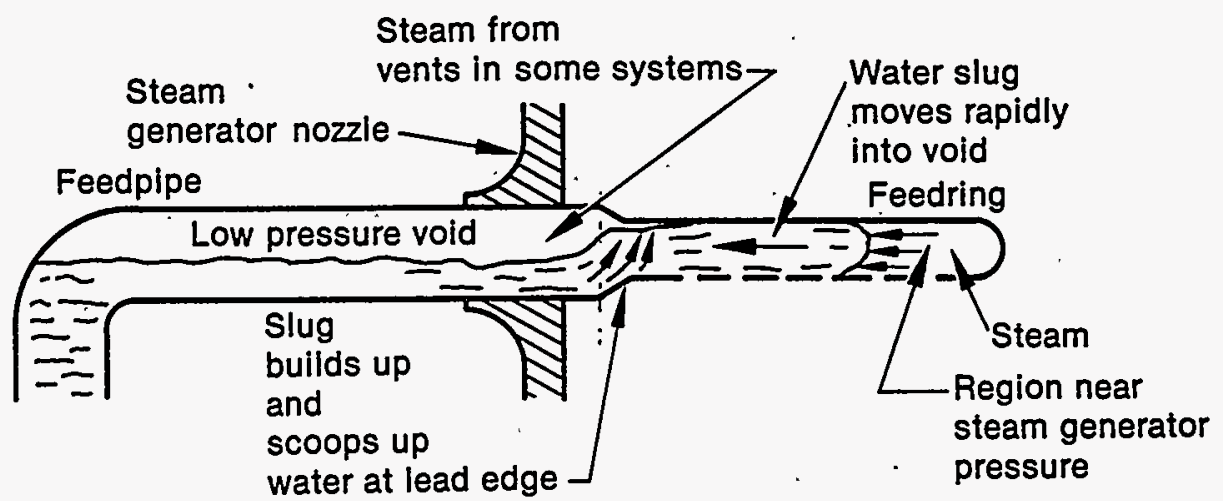

(c) Possible Slug Acceleration into Void

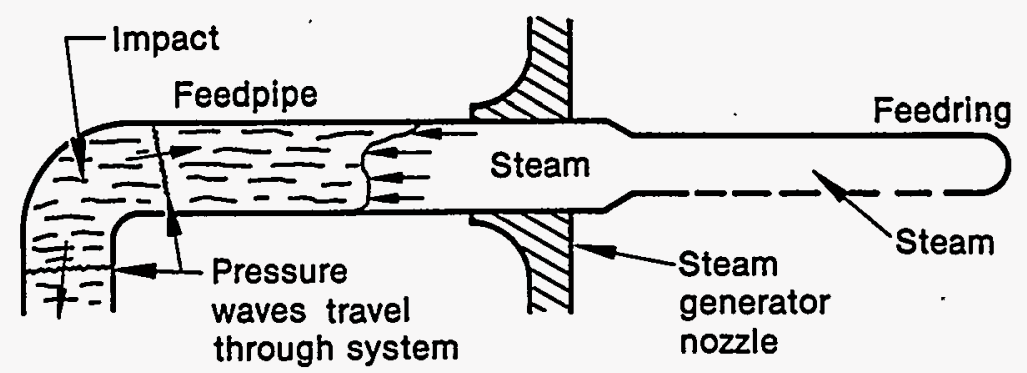

(d) Possible Water Slug Impact INEL 2 1076'

Figure 40. Sequence of events leading to water hammer (Han and Anderson 1982). 
create enough turbulence to form a slug, as shown in Figure 40(b). The slug seals the main feedwater line and thus prevents the normal flow of steam from the steam generator from replenishing the trapped steam void being condensed by the cold feedwater layer. As steam is condensed at the steamwater interface, the pressure of the trapped steam drops, and, as a result, a slug accelerates into the void, away from the steam generator, as shown in Figure 40(c). The forces causing acceleration of the slug can be very large and include the steam generator pressure, which can be in excess of 1000 $\mathrm{psi}$, on one side and trapped vapor pressure on the other side. As the condensation continues, the trapped steam pressure decreases and, as a result, the slug achieves a very high velocity. As shown in Figure 40(d), when a slug traveling with a high velocity impacts an incoming water column, a pressure pulse is produced. The velocity of the slug at the time of impact depends on the acceleration forces acting on it and the distance it has traveled. This distance is usually equal to the length of the horizontal section of the feedwater piping adjacent to the feedwater nozzle. The pressure pulse may be as high as thousands of psi for a severe water hammer. However, because of the incompressibility of the water, inelastic expansion of piping reduces the amplitude of the pressure wave and a smaller value is transmitted through the system (Izenson, Rothe, Wallis 1988). The pressure pulse travels throughout the system and could damage the feedring, piping and supports, or valve internals, such as a check valve disk.

\subsubsection{Top-Feed Steam Generators}

There have been about 37 PWR steam generator water hammer events associated with the main and auxiliary feedwater lines of 17 top-feed steam generators, as listed in Table 8. ${ }^{1}$ Five of these events occurred prior to commercial operation, whereas the others occurred afterward. The data

\footnotetext{
1 Table 8 includes the events reported to the USNRC. However, many more events may not have been reported because they involved no safety considerations. Some nuclear industry participants at the 1986 EPRI Water Hammer Workshop estimated that unreported events may occur at least an order of magnitude more frequently than events reported in the databases (Uffer 1987).
}

show that the reported occurrences of steam generator water hammer events dramatically decreased after $1979 ; 28$ events occurred during the 1970 s, whereas only 6 occurred during the 1980 s. The main reason for this decrease is design modifications and operating procedure changes at U.S.PWR plants to reduce the occurrence of water hammer events. These mitigative actions are discussed in Section 9.4.

The original feedrings in the top-feed steam generators had bottom-discharge holes, as shown in Figure 41. When the water level in the steam generator dropped below the feedring, the feedring became uncovered and drained in 1 to 2 minutes. As discussed, the draining of a feedring can lead to a water hammer. The design of the feedrings was eventually modified at most of the operating Westinghouse and Combustion Engineering units to mitigate water hammers. The holes in the bottom-discharge feedring were plugged, and Jtubes or discharge elbows were installed on the top of the feedring, as shown in Figures 5 and 14.

Water hammer damage for most of the reported events was limited to the plant piping support systems. However, in a few cases water hammer events have resulted in significant damage to the steam generator internals including cracked feedrings and expanded thermal sleeves, and cracking and bulging of the main feedwater line. The water hammer-induced shocks to the steam generator instrumentation have led to spikes in the readings (such as differential pressure) that have initiated safety injections in some plants.

Indian Point Unit 2. The most damaging event was at Indian Point Unit 2 in 1973 (USNRC 1980), which resulted in a 180-degree circumferential through-wall crack in a $460-\mathrm{mm}$ (18-in.) diameter main feedwater line at the containment penetration. The water that sprayed from the ruptured pipe caused gross thermal deformation of the metal containment liner near this juncture. The water hammer also produced a large bulge in the horizontal run of the main feedwater pipe inside the containment. The crack was caused by excessive bending stresses, possibly resulting from dynamic reaction forces at the support points along the line. 
Table 8. PWR steam generator water hammer events. ${ }^{1}$

\begin{tabular}{|c|c|c|c|c|}
\hline Plant & $\begin{array}{l}\text { NSSS } \\
\text { Vendor }\end{array}$ & $\begin{array}{l}\text { Commercial } \\
\text { Operation }\end{array}$ & Event Date(s) & $\begin{array}{l}\text { Number } \\
\text { of Events }\end{array}$ \\
\hline Beaver Valley $2^{2}$ & W & $11 / 87$ & $04 / 89,92$ & 2 \\
\hline Calvert Cliffs 1 & $\mathrm{CE}$ & $05 / 75$ & $08 / 29 / 74,12 / 30 / 74,05 / 12 / 75^{3}$ & 3 \\
\hline Calvert Cliffs 2 & $\mathrm{CE}$ & $04 / 77$ & $05 / 18 / 76^{3}$ & 1 \\
\hline D.C. Cook & W & $07 / 75$ & $01 / 02 / 76^{3}, 03 / 10 / 77$ & 2 \\
\hline $\begin{array}{l}\text { Haddam Neck } \\
\text { (Conn, Yankee) }\end{array}$ & $\mathrm{W}$ & $01 / 68$ & $(\text { date? })^{3,4}$ & 1 \\
\hline Indian Point 2 & W & $09 / 73$ & $11 / 13 / 73,01 / 29 / 74$ & 2 \\
\hline Maine Yankiee & $\mathrm{CE}$ & $12 / 72$ & $01 / 25 / 83$ & 1 \\
\hline Millstone & $\mathrm{CE}$ & $12 / 75$ & $05 / 09 / 75^{3}$ & 1 \\
\hline Palisades & $\mathrm{CE}$ & $12 / 71$ & Spring 1981 & 1 \\
\hline San Onofre 1 & W & $01 / 68$ & $04 / 29 / 72,01 / 14 / 74,11 / 21 / 85^{5}$ & 3 \\
\hline San Onofre 2 & $\mathrm{CE}$ & $08 / 83$ & $03 / 30 / 81$ & 1 \\
\hline Surry 1 & W & $12 / 72$ & $10 / 01 / 72$ & 1 \\
\hline Turkey Point 4 & W & $04 / 73$ & $06 / 30 / 73,01 / 05 / 74$ & 2 \\
\hline Turkey Point 3 & W & $07 / 72$ & $01 / 14 / 73$ & 1 \\
\hline Yankee Rowe & W & $06 / 61$ & $\begin{array}{l}\text { Between unit startup (1/61) and } \\
1965\end{array}$ & 1 \\
\hline Zion 2 & W & $12 / 73$ & $\begin{array}{l}08 / 29 / 74,12 / 30 / 74,05 / 25 / 76 \\
06 / 20 / 76,07 / 10 / 77,09 / 03 / 80\end{array}$ & 6 \\
\hline Zion 1 & W & $06 / 73$ & $\begin{array}{l}09 / 26 / 76,07 / 08 / 77^{3}, 07 / 10 / 77 \\
09 / 14 / 78,12 / 15 / 78,03 / 02 / 79 \\
03 / 16 / 79,06 / 08 / 79\end{array}$ & 8 \\
\hline \multicolumn{4}{|l|}{ TOTAL: 17 Plants } & 37 Events \\
\hline \multicolumn{5}{|c|}{${ }^{2}$ Duquesne Light (1993). } \\
\hline \multicolumn{5}{|c|}{${ }^{3}$ Reported as nondamaging. } \\
\hline \multicolumn{5}{|c|}{$\begin{array}{l}{ }^{4} \text { It is likely that the event took place before } 1 / 1 / 69 \text { because it is not reported by Chapman et al. (1982), which reviewed } \\
\text { the events since } 01 / 01 / 69 \text {. }\end{array}$} \\
\hline
\end{tabular}




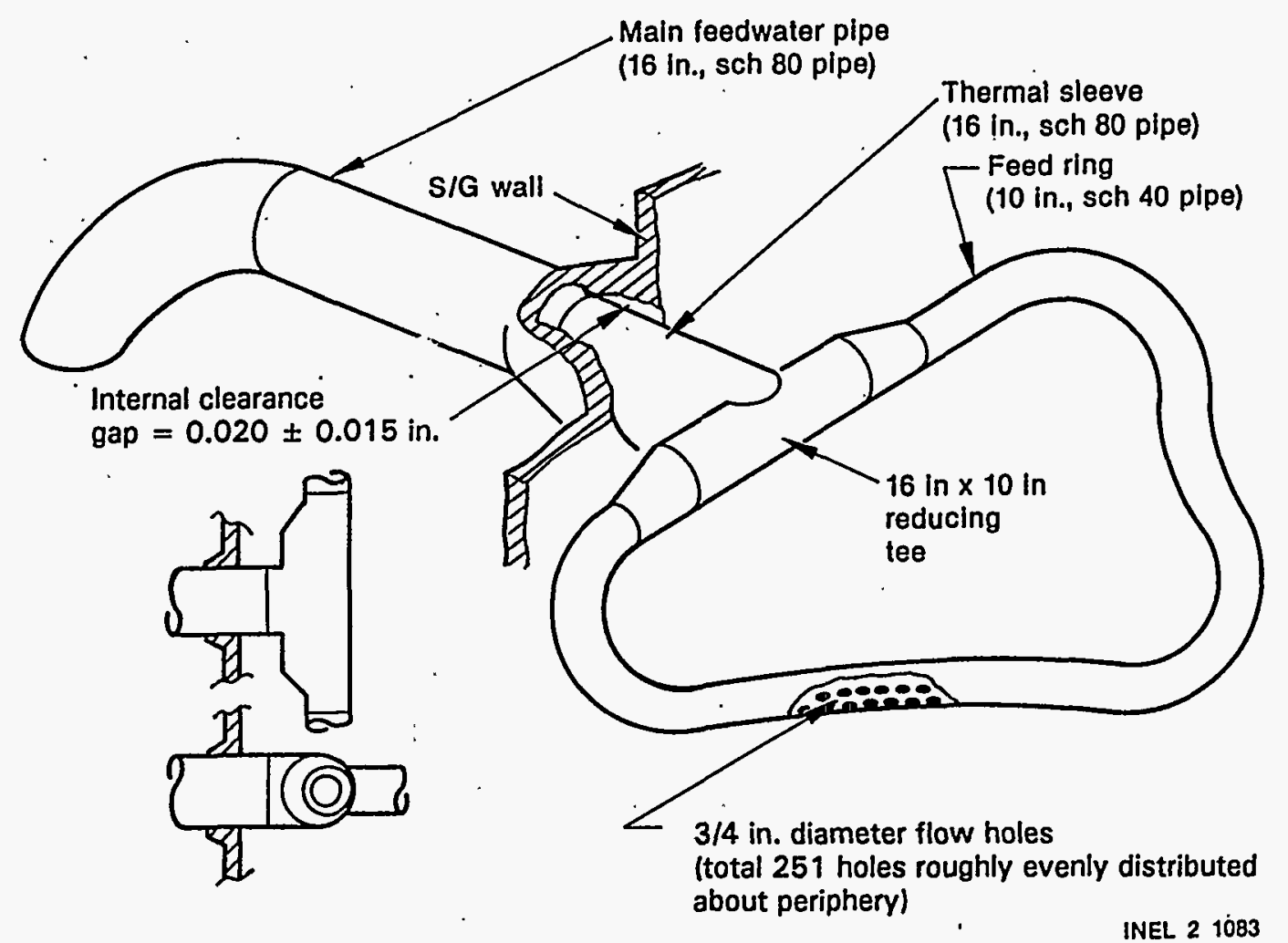

Figure 41. Older vintage feedring design for top feed steam generators (Han and Anderson 1982).

The Indian Point Unit 2 water hammer resulted from a steam/cold-water interaction in the main feedwater piping adjacent to the steam generator. Of the four steam generators at Indian Point Unit 2 , this line had the longest [3.25-m (10-ft 8-in.)] horizontal run immediately upstream of the steam generator nozzle. When the level in the steam generator dropped below the feedring, the sparging holes on the underside of this ring allowed the water to drain rapidly from the ring and from the horizontal feedwater piping outside the steam generator. The feedring and line then refilled with steam from the steam generator. Subsequent introduction of cold auxiliary feedwater to restore the steam generator level led to a water hammer that caused the damage. To preclude the recurrence of water hammer events, the elevation of the long horizontal run of feedwater piping outside the steam generator was lowered about 0.4 m (16 in.) to prevent the water in this horizontal run from draining into the steam generator whenever the water level dropped below the feedring. The modification was not necessary in the other three steam generator inlet lines because the horizontal runs were shorter, less than half the length of the horizontal run in the affected line. New restraints were added both inside and outside the containment near the feedwater line penetration area. The feedring was modified to prevent rapid draining by plugging the sparging holes and installing J-tubes on the top of the ring.

San Onofre Unit 2. On March 30, 1981, a steam generator water hammer event occurred while operators were performing the feedline water hammer test during hot functional testing at San Onofre Unit 2. The feedring of the affected steam generator was deliberately uncovered for two hours prior to performing the water hammer test. This was a severe water hammer test because 2 hours 
duration is not operationally representative. Even though the feedring was equipped with discharge elbows, the 2-hour duration was enough time to drain the feedring, which then filled with steam. When full flow of auxiliary feedwater rapidly initiated, the steam in the feedring got trapped because the flow area of the discharge elbows was inadequate. The cold auxiliary feedwater condensed the trapped steam, which created a partial vacuum in the relatively thin-walled (Schedule 40) feedring and caused it to collapse. The U-bolts at the feedring support brackets were deformed beyond the elastic limit, and some Ubolts were failed at the threads. The corrective actions included replacing the collapsed feedring with a Schedule 120 pipe, increasing the diameter of discharge elbows from 38 to $89 \mathrm{~mm}$ (1.5 to 3.5 in.), and installing a vent assembly on the distribution box, as shown in Figure 14. Also, actions such as much slower auxiliary feedwater initiation were taken to prevent the formation of a vacuum in either the feedring or distribution box upon the addition of cold water (Scherer 1981, Stoller 1991).

Maine Yankee. In 1983, the Maine Yankee plant was tripped from full load. The auxiliary feedwater pumps started automatically as designed, to restore water level in the steam generators. A water hammer occurred about 15 minutes after the reactor trip and caused rupture of the Number 2 main feedwater line near the steam generator feedwater nozzle where, as discussed in Section 6.2.1, a preexisting crack caused by flow stratification may have been present. The crack was at the bottom of the pipe, right at an internal stress riser. Subsequent inspection found a similar crack at the same location in the No. 3 main feedwater line near the steam generator feedwater nozzle. This supports the postulation that the crack had initiated by thermal fatigue (Garrity 1983).

Each steam generator feedring was later modified by closing off all 76 bottom-mounted, $25-\mathrm{mm}$ (1-in.) diameter nozzles and installing 28 top-mounted, 90-mm (3.5-in.) diameter elbows (Stoller 1987). Other preventive actions included removing stress risers from the pipe inside surface and modifying operations instruction and guidance to reduce the probability of thermal cycling and steam generator water hammer events. Maine Yankee also considered expanding the thermal sleeve into the nozzle to reduce the rate of draining from the feedring during a loss-of-feedwater event. Damaged supports were also repaired (Garrity 1983).

San Onofre Unit 1. On November 21, 1985, a main feedwater pump at San Onofre Unit 1 (an older 3-loop Westinghouse plant) experienced a loss of power, whereas another main feedwater pump remained energized. The heatercondenser train of the portion of the main feedwater system that experienced the power loss was exposed to the high pressure of the main feedwater because multiple check valves failed, which allowed back' flow of high-pressure feedwater. This high-pressure exposure resulted in a ruptured tube and a damaged shell in the condenser. The check valve failures allowed the water in the long, horizontal piping to drain through the condenser rupture. Then steam from the steam generator filled extensive portions of the feedwater piping (Bamford 1987).

Auxiliary feedwater flow was established and the isolation valves and flow control valves were closed after the power was restored. Once the isolation valves were closed, the draining of the feedwater through the condenser rupture stopped. Refilling of the long, steam-filled, horizontal feedwater lines with cold auxiliary feedwater led to a severe water hammer, producing a traveling pressure wave that generated very high loads. The feedwater piping in the B steam generator loop experienced the worst loads because of a long horizontal run of piping. The $254-\mathrm{mm}$ (10-in.) diameter pipe inside the containment was distorted from its original configuration; pipe supports were damaged; and a 2-m (80-in.) long crack was generated (Bamford et al. 1987). A full description of this event may be found in a report prepared by the USNRC (1986b). The corrective actions included replacing faulty and damaged 
check valves, implementing logic which closes the flow-control valve upon a loss of main feedwater, and installing redundant check valves in the feed water piping (Bamford et al. 1987).

Palisades. Condensation of trapped steam and the resulting collapse of the steam bubbles have caused water hammers in auxiliary feedwater lines. During an inspection at Palisades (an older vintage Combustion Engineering plant), the following auxiliary feedwater system damage was confirmed (USNRC 1984a):

- A thermal sleeve was cracked

- One of the three hold-down clamps for the sparger was missing

- A weld at an elbow was broken

- A clamp on a riser pipe to a sparger was broken.

An inspection conducted before the discovery of the steam generator internal damage revealed that eight hangers on the auxiliary feedwater piping were also loose or damaged. These hangers were inspected before the beginning of the fuel cycle and were considered in good condition at that time. The damage described above was consistent with the occurrence of a water hammer during the fuel cycle.

Beaver Valley Unit 2. Based on the results of the extensive engineering analysis of previous events at Beaver Valley Unit 2, it was hypothesized that the auxiliary feedwater line for Steam Generator $C$ had been subjected to two water hammers caused by steam bubble formation and its collapse since the plant went operational in 1987, one event in April 1989 and another in 1992. The mechanical snubbers on the auxiliary feedwater lines were mechanically frozen during both events. The cause of these snubber failures was excessive compressive or impact loads apparently produced by water hammer events (Duquesne Light 1993).
The location of the inside containment check valve on the steam generator $\mathrm{C}$ auxiliary feedwater line and the piping layout at Beaver Valley Unit 2 have the potential to cause water hammer. The inside containment check valve is near the main feedwater line and at a highier elevation than the auxiliary feedwater supply tank minimum water level. Because of its proximity to the main feedwater line, several feet of piping upstream of the check valve is likely to be at a higher temperature than the typical auxiliary feedwater temperature; measured temperatures for the top and bottom of the pipe were $131^{\circ} \mathrm{C}\left(268^{\circ} \mathrm{F}\right)$ and $93^{\circ} \mathrm{C}\left(200^{\circ} \mathrm{F}\right)$, respectively, at about $0.6 \mathrm{~m}(2 \mathrm{ft})$ upstream of the check valve. The higher temperatures are conducive to steam voiding if leakage through check valves is present. Therefore, there is potential for a water hammer caused by steam bubble collapse if flow of cold auxiliary feedwater is rapidly initiated to the voided auxiliary feedwater line for steam generator C (Duquesne Light 1993).

The corrective actions included replacing the mechanical snubbers with hydraulic snubbers having a higher load rating to withstand the loads generated by a water hammer event. Other actions include frequent monitoring of temperatures and pressures in the auxiliary feedwater lines and inservice inspection of the lines and their supports in the containment following an unplanned start of the auxiliary feedwater pumps that results in rapid initiation of auxiliary feedwater flow.

\subsubsection{Preheat Steam Generators}

The preheat steam generator is a somewhat newer design, shown in Figure 4. Lessons learned from the experience with the water hammer events associated with the top-feed steam generators were incorporated in the preheat steam generator designs. Thus, it was believed that the preheat steam generators were not susceptible to water hammer events that had occurred in the top-feed steam generators. However, a water hammer occurred in the auxiliary feedwater line of a preheat steam generator at KRSKO, a 2-loop Westinghouse plant in the former Yugoslavia, during preoper- 
ational testing of the auxiliary feedwater line. The schematic for the main and auxiliary feedwater systems for KRSKO is shown in Figure 42.

The water hammer at KRSKO was caused by a steam bubble collapse in an auxiliary feedwater line during a hot functional test in July, 1981. The horizontal portion of the line where the water hammer occurred was about $16 \mathrm{~m}(52.5 \mathrm{ft})$ below the auxiliary feedwater nozzle, as shown in Figure 43. The auxiliary feedwater pumps were being run intermittentl! '. 'ring the test. Damage was mainly limited to ins, $\alpha$ e the containment: the piping was shifted and bulged about $6 \mathrm{~mm}(0.25 \mathrm{in}$.) near the secondary wall (the probable location of water slug impact), and the pipe hangers were damaged. The piping movement was negligible in the intermediate building but paint on the auxiliary feedwater piping was blistered back to the motordriven auxiliary feedwater pumps (Sexton, Kasahara, and Uffer 1982).

The sequence of events that led to the KRSKO water hammer are not well understood. One sequence of events, though unlikely, that could have caused the observed damage is hypothesized here. The steam generator water level was below the elevation of the auxiliary feedwater nozzle internal extension discharge. Then the significant back leakage of steam from the steam generator through the auxiliary feedwater line took place and caused the observed paint damage back to the motor-driven auxiliary feedwater pumps. The check valves in the discharge and suction lines of the auxiliary feedwater pumps had to have leaked to allow the back leakage of steam. The significant back leakage also resulted in the presence of steam in the horizontal portion of the auxiliary feedwater line. Then, when the cold feedwater was introduced into this portion of the line, the water hammer caused by steam bubble collapse occurred (Sexton, Kasahara, and Uffer 1982).

The KRSKO event shows that multiple component failures can lead to a water hammer in a preheat steam generator notwithstanding the fact that the preheat steam generator designs incorporate several features that have been successful in essentially eliminating steam generator water hammers. As discussed, failure of multiple check valves was responsible for the water hammer at San Onofre 1 in 1985 and Beaver Valley Unit 2 in 1989 and 1992. 
艺

$\stackrel{\infty}{\infty}$

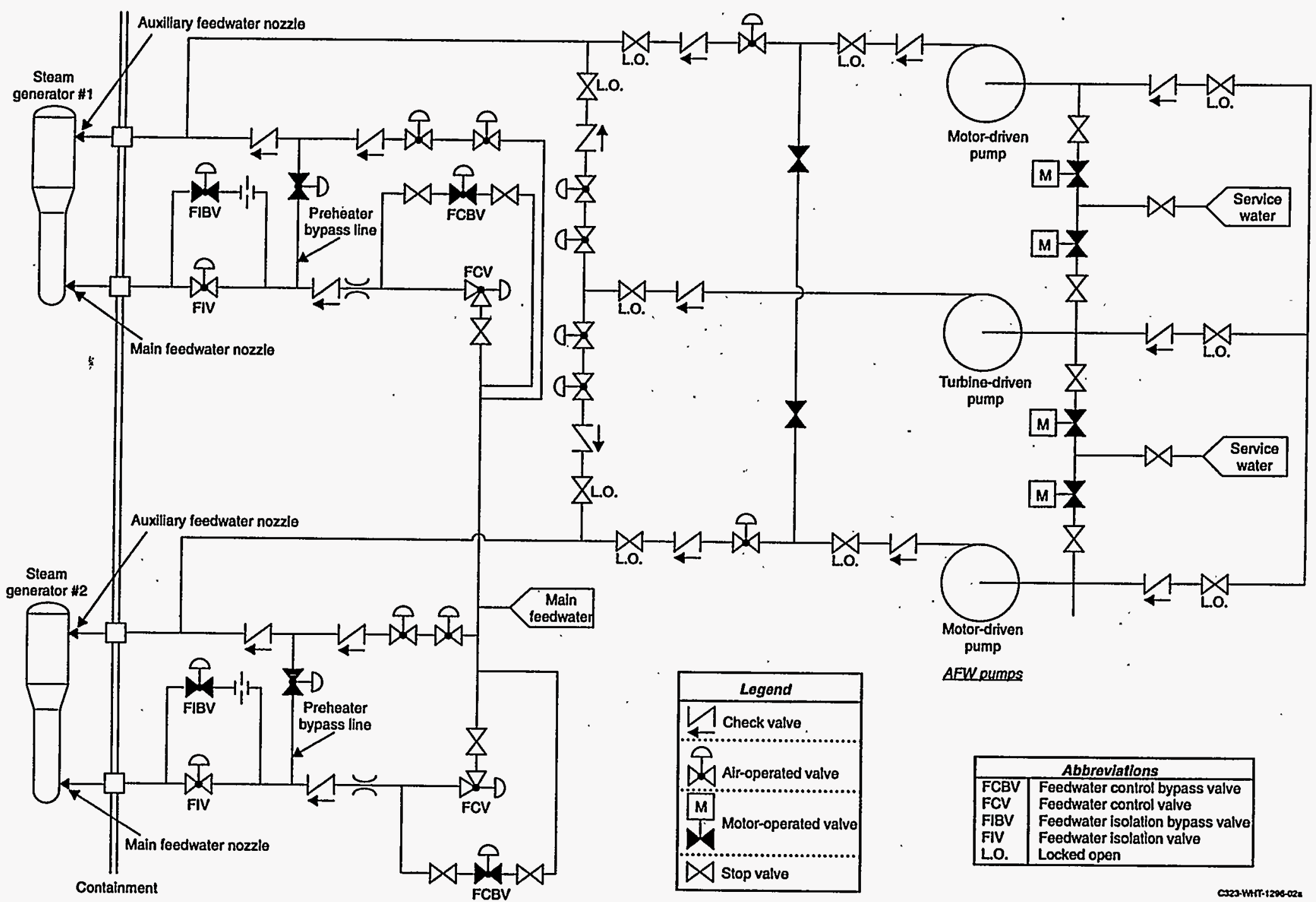

Figure 42. Main and auxillary feedwater systems for KRSKO (Sexton, Kasahara, and Uffer 1982). 


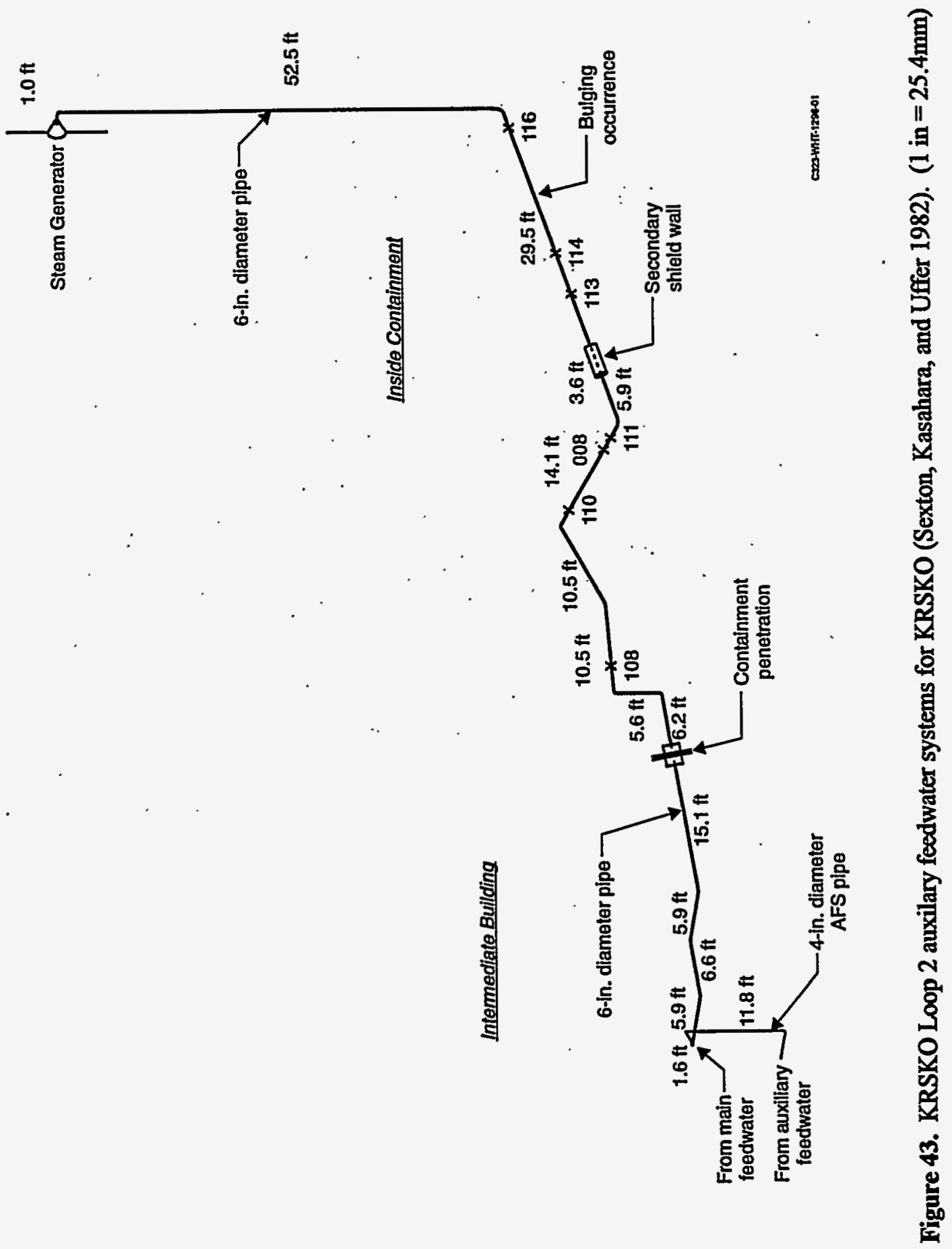




\section{DEGRADATION MECHANISMS}

As discussed in Section 6, the main degradation mechanisms affecting the PWR feedwater lines are thermal fatigue and flow-accelerated corrosion. Thermal fatigue has caused through-wall cracking and leakage in sections of PWR feedwater piping where stratified flow conditions were present during startup and hot standby conditions; there have been no reported ruptures attributed to fatigue damage. The affected piping sections typically include a portion of the piping adjacent to the feedwater nozzle and, in some cases, the long horizontal portions of the piping inside the containment, which is discussed later in Section 9.2. Flow-accelerated corrosion has caused wall thinning at several susceptible locations in the piping and, in some instances, has led to catastrophic rupture. Factors contributing to the flow-accelerated corrosion damage are feedwater temperature, chemistry, and velocity, and piping layout and materials. This section describes the phenomena associated with these two mechanisms and discusses the factors affecting the damage caused by these mechanisms.

\subsection{Thermal Fatigue.}

PWR feedwater lines and nozzles are subject to both low- and high-cycle thermal fatigue. Lowcycle thermal fatigue is caused by plant heatups, cooldowns, thermal stratification, water hammer events, and thermal shocks. High cycle thermal fatigue is caused by thermal striping (defined below), which is associated with thermal stratification, and turbulent mixing. The auxiliary feedwater lines, if connected to the main feedwater line, are potentially susceptible to thermal cycling during normal operation.

\subsubsection{Thermal Stratification}

The thermal expansion loads imposed on the feedwater piping during plant heatup and cooldown cycles and feedwater injection following a reactor trip were included in the stress analyses during the design of the piping but fatigue analyses were not required. Some analyses of the feedwater nozzles subject to these design transients have shown acceptable fatigue usage factors for the life of the plant. Because the thermal stresses in the feedwater piping near the piping-to-nozzle junction are lower than those in nozzles, these transients do not contribute significantly to fatigue cracking in the piping (Thurman, Mahlab, and Boylstein 1981). However, the original design of the piping did not consider the effects of stratified flows, which are observed during hot standby and at low power during heatup, and these conditions can impose stresses of high magnitudes. Therefore, the fatigue damage in the PWR feedwater piping has been much greater than originally expected. The reported cracking incidents have been found to be associated with the presence of stratified flows.

Stratification Phenomena. Stratified flows take place in horizontal sections of piping and consist of hot and cold fluids separated into two layers because of their density difference. The propensity for stratification of a fluid in horizontal piping can be correlated to its Froud number, which is the ratio of the inertial force (velocity head) to the force of gravity (buoyancy head) acting on the fluid. The velocity head is determined by the relative velocities between the two fluids. The buoyancy head is caused by the density difference between the hot (top) and cold (bottom) regions of the fluid in the pipe, and its magnitude is determined by the difference in temperature between the two regions. Low flow rates and high temperature differences (small Froud number) promote thermal stratification in horizontal piping. In the case of the feedwater piping, thermal stratification occurs when the cold auxiliary feedwater, introduced at low flow rates into the main feedwater line during plant startup and hot standby conditions, flows under the warmer coolant present in the piping.

An interface layer (mixing zone) is developed between the hot and cold fluid layers, as shown in Figure 44(a) (Miksch et al. 1985). The elevation of the interface layer (height of the cold fluid layer) and its thickness depend primarily on the mass 


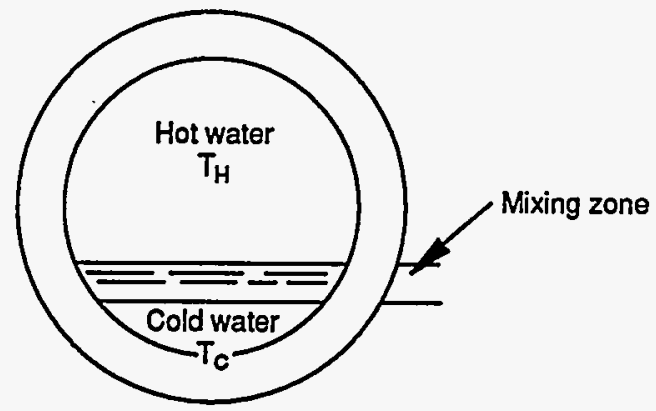

(a) Fluid temperature distribution.

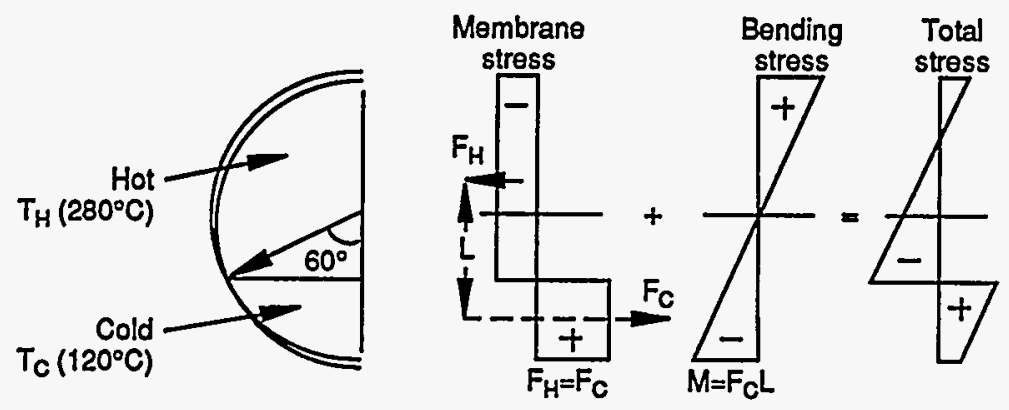

(b) Theoretical axial stress distribution. Mixing zone at $60^{\circ}$.

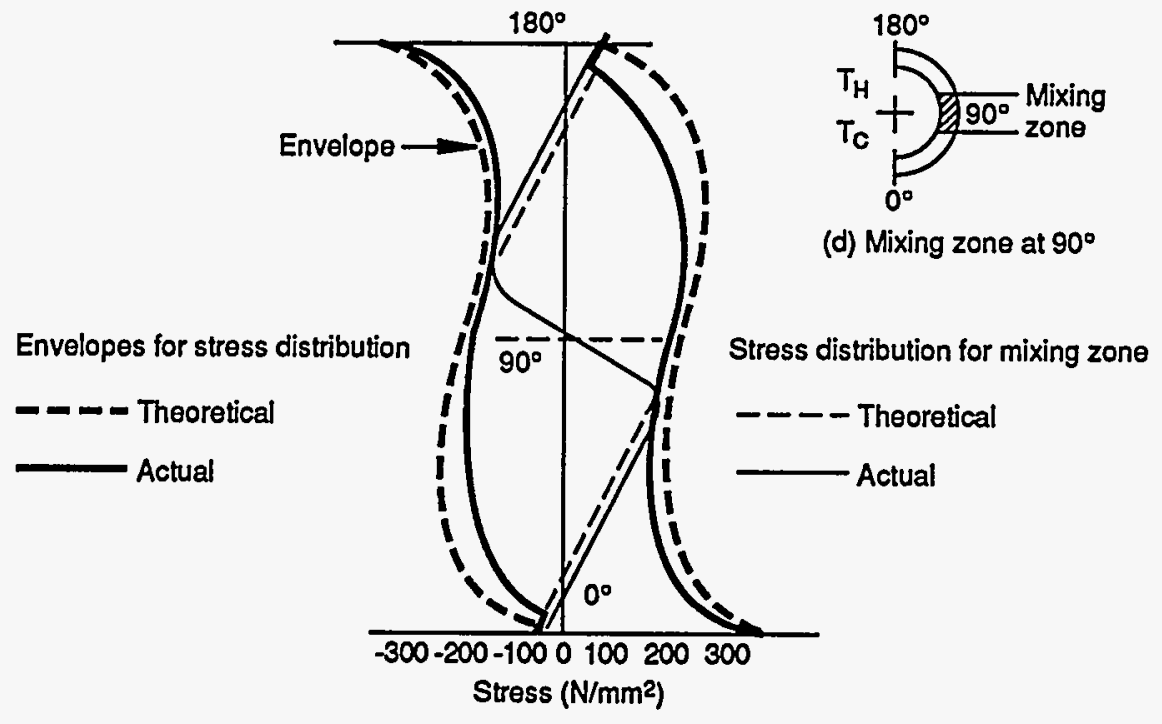

(c) Envelopes for theoretical and realistic stress distributions

N93 0050

Figure 44. Thermal stresses in a pipe with stratified flow (Miksch et al. 1985). Copyright Elsevier Science Publishers; reprinted with permission. 
flow and density ratio. Instabilities occur in the interface layer because of induced wave formation as the relative velocity between the hot and cold fluids increases. The wavy motion of the coolants in the interface layer introduces substantial temperature fluctuations at a fixed position in the layer and introduces small-amplitude cyclic stresses in the inside surface of the adjacent piping in contact. These stresses penetrate only a short distance into the wall, causing high-cycle fatigue damage. This high-cycle fatigue phenomenon is also known as thermal striping and is discussed in Section 7.1.2.

Stratified flow introduces through-wall axial and circumferential bending stresses whose magnitudes are determined by the top-to-bottom temperature difference $\left(T_{H}-T_{C}\right)$, and the elevation and thickness of the interface layer. Figure 44(b) shows the theoretical distribution of the axial bending stresses caused by stratified flow when the interface layer is at 60 degrees from vertical. This distribution assumes that the ends of the horizontal section of the piping are constrained from rotation and the thickness of the mixing layer is zero. This stress distribution is comparable to the stress distribution in a bimetallic strip subjected to a uniform temperature change. The resultant axial stresses are presented as the sum of the membrane and bending stresses. The portion of pipe below the mixing layer experiences tensile axial stresses, whereas the portion above the mixing layer experiences predominantly compressive axial stresses. The theoretical maxinnum axial stresses are near the mixing layer. The axial stresses need to be multiplied by a stress concentration factor introduced by any geometric discontinuity such as the counterbore typically present in the feedwater piping. Distribution of the axial stresses is symmetric with respect to the vertical diameter of the pipe cross section, provided the end constraints and the geometric discontinuity, if any, are also symmetric.

Circumferential bending stresses are produced because of the temperature difference between the pipe sections above and below the interface layer. However, these stresses are of much smaller mag- nitude than the axial ones (Woodward 1983,Talja and Hansjosten 1990). For example, in some flowstratification experiments performed at the HDR (Heissdampfreaktor) test facility, the measured maximum stress on the outside surface of the piping was $36 \mathrm{MPa}(5,200 \mathrm{psi})$ in the circumferential and $390 \mathrm{MPa}(56,550 \mathrm{psi})$ in the axial direction. The much larger magnitude of the axial stress explains why the fatigue cracks found in the feedwater piping generally have a circumferential orientation.

Flow rate variations cause the interface layer to be raised or lowered. In the feedwater system, these changes are caused by the auxiliary feedwater being turned on or off to adjust the steam generator water level. As the feedwater flow rate changes, the layer moves between the upper and lower portion of the pipe cross section and changes the through-wall bending stress distribution introduced by the stratified flow, which causes low-cycle fatigue damage. Figure 44(c) shows the predicted stress distributions for a mixing layer at 90 degrees as shown in Figure 44(d), and presents the envelope for the distribution as a function of the height of the mixing layer. The dashed line represents the theoretical axial stresses, and the solid line represents an actual stress distribution, which accounts for the thickness of the mixing layer and the heat transfer taking place in the piping material (Miksch et al. 1985). Any given point on the pipe wall will experience a maximum change in its axial stress when the interface layer passes by. These cyclic stresses are through-wall and cause both crack initiation and growth.

The piping inside-surface temperatures, under steady state conditions, are about equal to the temperatures of the fluid that is in contact with the piping at that location. Because the fluctuations in the feedwater flow rate take place at a relatively low frequency, the piping inside surface temperatures are also about the same as the fluid temperatures (Talja and Hansjosten 1990, Thurman, Mahlab, and Boylstein 1981). The outside surface temperatures follow the inside surface temperatures with some time delay. 
The resulting piping-wall temperature distribution is plant specific because, in addition to the hot and cold coolant temperature and flow rate, it depends on piping layout. These low-frequency fluctuations in the piping wall temperatures can be estimated by monitoring the outside surface temperatures. However, as discussed in the next section, the high-frequency temperature fluctuations caused by thermal striping cannot be estimated by monitoring the outside surface temperature.

Global Thermal Stratification. If the stratification persists over a long section of pipe, and the temperature difference between the hot and cold fluids is large, the pipe will bow (macroscopic displacement), resulting in high loads on the supports along its length and on the elbows or nozzles at its ends. The stress distribution will be similar to the one shown in Figure 44, except it is modified by the constraints exerted by the supports. This type of stratification is termed global thermal stratification (Su 1990). Such stratification occurs in feedwater piping under two conditions: (1) existence of long horizontal runs of pipes between the auxiliary feedwater connection and the steam generator nozzle, and (2) introduction of cold water at a low flow rate into a hot feedwater system. The feedwater piping at Beaver Valley 1, for example, satisfies these conditions and has experienced global thermal stratification (Van Duyne et al. 1991).

Local Thermal Stratification. If the stratification persists over a short section of pipe, it is termed local thermal stratification. Local thermal stratification produces a complex stress state in the piping because of its short length, the end constraints exerted by the feedwater nozzle and elbow, and the geometric discontinuities (discussed below) present in the piping. Finite element analyses are generally performed to calculate the stresses.

Local thermal stratification occurs more often in PWR feedwater piping than global stratification. At several PWR plants, local thermal stratification has been found in the short horizontal section of the feedwater piping connected to the feedwater nozzle. The other end of the horizontal section is generally attached to a 90-degree or a 45-degree elbow. Plant operational data indicate that the period for the cyclic thermal stratification is generally longer than several minutes and is typically associated with the automatic cycling of the auxiliary feedwater flow. At the Sequoyah plant, for example, the auxiliary feedwater system in the automatic control mode cycles about three times per hour.

Major fatigue cracks have been reported at the geometric discontinuity. In addition, the downstream end of the elbow experiences thermal stratification and resulting stresses are higher than for the straight pipe. For example, in one analysis, the peak stresses for the elbow configuration (elbow directly connected to the feedwater nozzle) were about twice those for the straight pipe configuration (Thurman, Mahlab, and Boylstein 1981).

Construction methods in conjunction with design and material considerations usually introduce two different geometric discontinuities that create significant stress concentrations in the piping: the weld between the nozzle and transition piece connecting to an elbow shown in Figure 16, and a counterbore, examples of which are shown in Figures 15 and 17. The stress concentration factor introduced by the counterbore depends on its angle $\alpha$ and depth $h$ defined in Figure 17(b). As angle $\alpha$ and depth $h$ increase, the stress concentration factor increases (Cofie et al. 1994).

The distribution of cyclic stresses introduced by local thermal stratification in a pipe cross section may be symmetric or asymmetric with respect to the vertical diameter. Symmetric distributions will lead to fatigue cracking that is also symmetric, as shown in Figures 22(b) and 27 (Loop 4). Otherwise, fatigue cracking will be asymmetric, as shown in Figure 27 (Loop 1). One possible reason for an asymmetric stress distribution is that the midplane of the elbow (first elbow from the feedwater nozzle) is not vertical. It is also possible to have some asymmetry in the geometric discontinuities.

Corrosion Fatigue. High-amplitude, low-frequency cyclic stresses imposed by thermal stratification have combined with coolant containing copper oxides, chlorides, and possibly 
oxygen in the auxiliary feedwater (if nitrogen cover is not provided to the coolant in the condensate storage tank) and caused corrosion-fatigue damage to the carbon steel feedwater piping and low-alloy steel feedwater nozzles. These piping and nozzle materials are susceptible to corrosion-fatigue if they contain sulfur inclusions such as manganese sulfides (Bamford et al. 1987). Corrosion products have been found on the crack surfaces in these components. Corrosion products, for example, have been found in the secondary cracks in the Sequoyah feedwater nozzle and in the nozzle bore cracks in the Indian Point Unit 2 feedwater nozzle.

The ASME Code design curves for carbon steel may be used to estimate the low-cycle fatigue damage to the feedwater nozzle and piping. However, these curves are based entirely on data obtained from in-air tests mainly at room temper- ature of small polished specimens and do not fully account for the LWR environmental effects. These curves were developed by applying factors of 2 on stress or 20 on cycles, whichever is greater, to the mean failure curve for the small polished specimens. A portion of these factors accounts for the effects of the environment; however, recent research results show that the effects of temperature and oxygenated coolant on carbon steel fatigue strength is not fully accounted for in these curves (Terrell 1988, Higuchi and Iida 1992). ${ }^{1}$ The low-cycle fatigue strength of smooth carbon steel specimens tested in air at $288^{\circ} \mathrm{C}\left(550^{\circ} \mathrm{F}\right)$ is lower than the mean failure curve, but it does not lie below the design curve, as shown in Figure 45. However, the low-cycle fatigue strength of carbon steel in high temperature $\left[-300^{\circ} \mathrm{C}\left(572^{\circ} \mathrm{F}\right)\right] \mathrm{oxy}$ genated pure water decreases with a decrease in strain rate, and, at lower strain rates $(\leq 0.01 \% / \mathrm{s})$, the fatigue strength lies below the design curve.

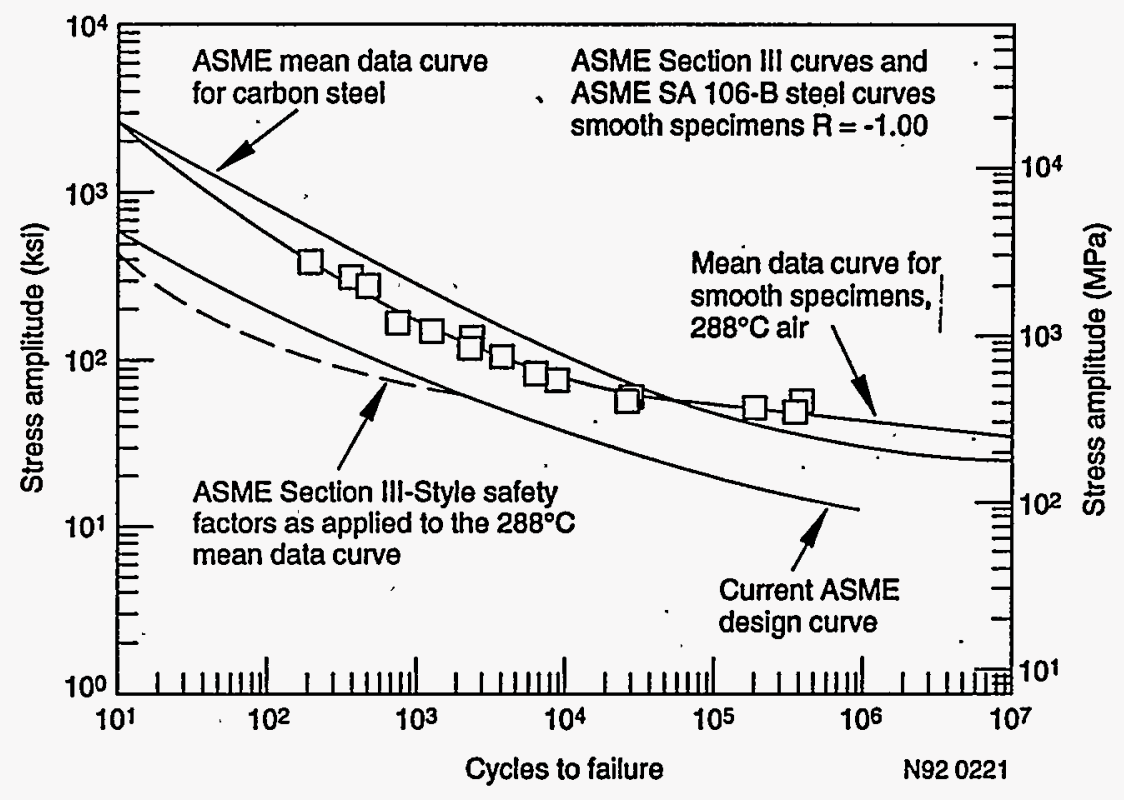

Figure 45. Fatigue data for SA-106B carbon steel smooth base metal specimens in air at room temperature and $288^{\circ} \mathrm{C}$ (Terrell 1988).

\footnotetext{
${ }^{1}$ Iida, K., et al. 1988. "Abstract of DBA Committee Report, 1988 - Survey of Fatigue Strength Data of Nuclear Structural Material in Japan," (K. Iida, Professor Emeritus, University of Tokyo, Tokyo).
} 
The need for incorporation of environmental effects in the ASME fatigue design curves for Class 1 carbon steel components is being evaluated by the Pressure Vessel Research Committee Working Group on Evaluation Methods.

\subsubsection{Thermal Striping and Turbulent Mixing}

As discussed above, thermal stratification can induce local, small-amplitude, cyclic stresses in the portion of the inside pipe surface that is in contact with the interface layer, if the flow rates are sufficiently high. These stresses are caused by oscillations of the fluid temperature, resulting from the interfacial mixing of the hot and cold fluids in the interface layer. As mentioned above, such interfacial mixing results in a process called thermal striping. The onset of interfacial mixing that leads to thermal striping can approximately be correlated with the initiation of a Kelvin-Helmholtz instability, which occurs when inertial forces overcome stratifying density differences between the fluid layers (Hafner and Spurk 1990).

Wolf et al. (1987) conducted thermal stratification experiments in horizontal feedwater lines at the HDR test facility in Germany. The experiments were performed at several different flow rates with thermocouples mounted on the inside pipe surface to measure metal temperatures. Thermal striping was observed only at relatively high flow rates (Deardorff et al. 1990). The test results and theory indicate that thermal striping is present when the gradient Richardson number, $R_{i}$, through the interface is less than 0.25 (Hafner and Spurk 1990, Turner 1973). The gradient Richardson number is the ratio of the density gradient and horizontal velocity gradient across the thickness of the interface layer and is given by

$$
R_{i}=-g(\partial \rho / \partial y) / \rho(\partial u / \partial y)^{2},
$$

where $g$ is the acceleration due to gravity, $\rho$ is the density, $u$ is the fluid velocity, and $y$ is the coordinate along the thickness of the interface layer (Turner 1973).

The typical frequency content of the metal temperature oscillations caused by thermal striping in the HDR tests was between about 0.01 and 2 $\mathrm{Hz}$, and the amplitude of the metal temperature oscillations was less than $50 \%$ of the difference in the hot and cold coolant layer temperatures. The amplitude of the metal temperature oscillations was smaller because of the finite heat transfer coefficient and thermal inertia of the pipe wall. The magnitude of the thermal striping stresses is highest on the inside-surface and reduces rapidly through the thickness. Therefore, the high-cycle fatigue damage caused by these stresses is limited to the pipe inside surface adjacent to the interface.

There are several differences between fatigue damage caused by thermal stratification and striping. Stresses produced by thermal stratification are through-thickness stresses and are mainly along the axial direction, whereas those produced by striping are mainly at the inside surface with little penetration through the thickness, and have a random orientation. The stresses produced by thermal stratification have large magnitudes and low cyclic frequencies, whereas the stresses produced by thermal striping are small and have high cyclic frequencies. So the fatigue damage caused by thermal stratification is low-cycle fatigue damage that affects the entire cross section of the piping, whereas the damage caused by thermal striping is a high-cycle fatigue damage that affects only the inside surface of the piping in the vicinity of the mixing layer and attenuates rather rapidly toward the pipe outside surface. Thus, thermal stratification contributes to both crack initiation and growth, whereas thermal striping contributes only to crack initiation. Cracks initiated by thermal stratification have a circumferential orientation, whereas cracks initiated by thermal striping have random orientations.

Turbulent mixing of cold feedwater leaking through the thermal sleeve-nozzle joint and the hot coolant in the steam generator has caused highcycle fatigue crack initiation at the feedwater nozzle bore and blend radius. These two sites are shown in Figure 23. Similarly, in a steam generator where the auxiliary feedwater is discharged directly into the steam generator, leaking coolant has caused cracking at the auxiliary feedwater nozzle blend radius (Westinghouse 1989). Turbulent mixing has also caused similar 
crack initiations at the BWR feedwater nozzle blend radii at several BWR plants. However, there is one difference between the designs of these two nozzles; the PWR steam generator feedwater nozzle does not have cladding on the inside surface whereas the BWR feedwater nozzle had stainless steel cladding. The presence of cladding contributes to the fatigue cracking because thermal stresses from the turbulent mixing are higher in the stainless steel than they would be in unclad base metal. In addition, the low-cycle temperature changes contribute to fatigue of BWR nozzles because the amplitude of metal temperature fluctuations caused by the turbulent mixing is larger in the cladding than in the unclad base metal. The larger fluctuations produces higher stresses in the cladding. Therefore, the stainless steel cladding on the feedwater nozzle has been removed at several BWR plants (Snaider 1980, Gordon et al. 1987).

Leaking cold feedwater has also caused circumferential cracking on the steam generator shell inside surface directly beneath the nozzle as shown in Figure 23. The mechanism causing the circumferential cracking is not known. Earlier experience related to BWR control rod drive return line nozzle cracking is reported here because of its similarity to the cracking on the steam generator shell. Circumferential cracking was discovered on the inside surfaces of the BWR reactor pressure vessel beneath the control rod drive return line nozzles at several plants, and it is believed that the cracking resulted from the cyclic thermal stresses related to stratified flow of cold water along the bottom of the nozzle and down the vessel wall as it mixes with the downflow of the rector vessel (Snaider 1980).

\subsubsection{Thermal Cycling}

Cyclic axial movement of an interface between hot and cold fluids is called thermal cycling. Such cycling takes place when a column of hot turbulent fluid from the main piping penetrates into a connecting branch line and interacts with a cooler stratified flow, which could be produced by valve leakage. Figure 46 illustrates how the turbulence in the main piping, such as main reactor coolant piping or feedwater piping, penetrates into a connecting branch line such as a safety injection line or an auxiliary feedwater line. The turbulence intensity decays exponentially from the header pipe into the branch line, but the temperature remains fairly constant over the length of several diameters and then decays. The length of turbulent penetration changes with time, and it is greater for a higher flow velocity in the main pipe and smaller for an increasing stratified flow in the branch line. ${ }^{1}$

Cyclic changes in the length and intensity of turbulent penetration produces corresponding changes in the length of the stratified fluid layers. As a result, the pipe in contact with the interface experiences cyclic stresses causing fatigue damage. Thermal cycling caused fatigue cracking in the safety injection lines (Farley Unit 2, Tihange Unit 2) and in a residual heat removal line (Genkai, a Japanese PWR) connected to the PWR primary coolant piping (Kim et al. 1993).

It appears that turbulent penetration alone, under certain operating conditions and with susceptible piping layouts, could produce thermal cycling in a branch line, even in the absence of any valve leakage. However, the effects of plant operating conditions on turbulent penetration are not well understood. The presence of thermally stratified fluids, in the absence of any valve leakage, has been detected in a branch line of a PWR plant, as illustrated in Figure 47. A plausible explanation for this presence of stratified fluids is as follows. The branch line travels a certain distance vertically from the main coolant loop and then runs horizontally, and it contains stagnant fluid. The turbulent penetration initially developed in the vertical section of the branch line, as shown in

1 The nuclear industry has performed this research and evaluation of the presence of thermal cycling, and also thermal stratification and striping, in unisolable reactor coolant system lines in response to the USNRC Bulletin 88-08, Thermal Stresses in Piping Connected to Reactor Coolant Systems, and its three supplements. 
Figure 47(a). Then, an operational transient such as a power change caused the turbulence to penetrate the full length of the vertical section and produce stratification in the elbow at the end and in the adjacent horizontal section of the branch line, as shown in Figure 47(b). With further changes in power, the length of the turbulent penetration receded and the stratified layer was no longer present. Thus, the base metal and welds of the elbow and the horizontal portion of the branch line experienced cyclic thermal stresses and fatigue damage.
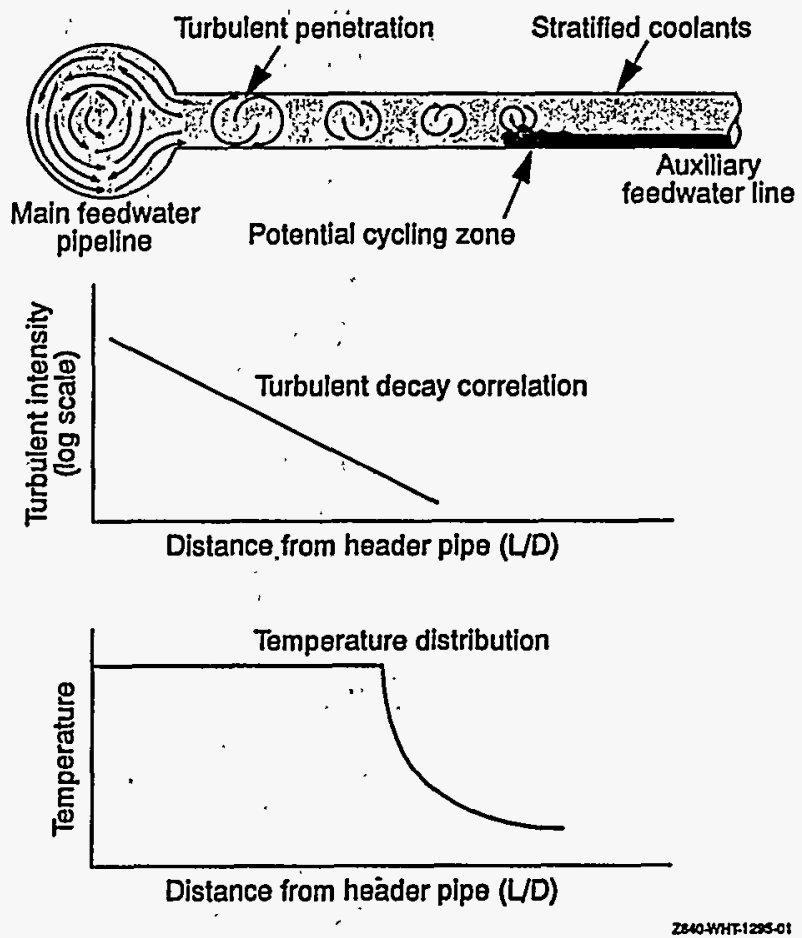

Figure 46. Turbulence interaction regions (Roarty 1993). Copyright Electric Power Research Institute; reprinted with permission.

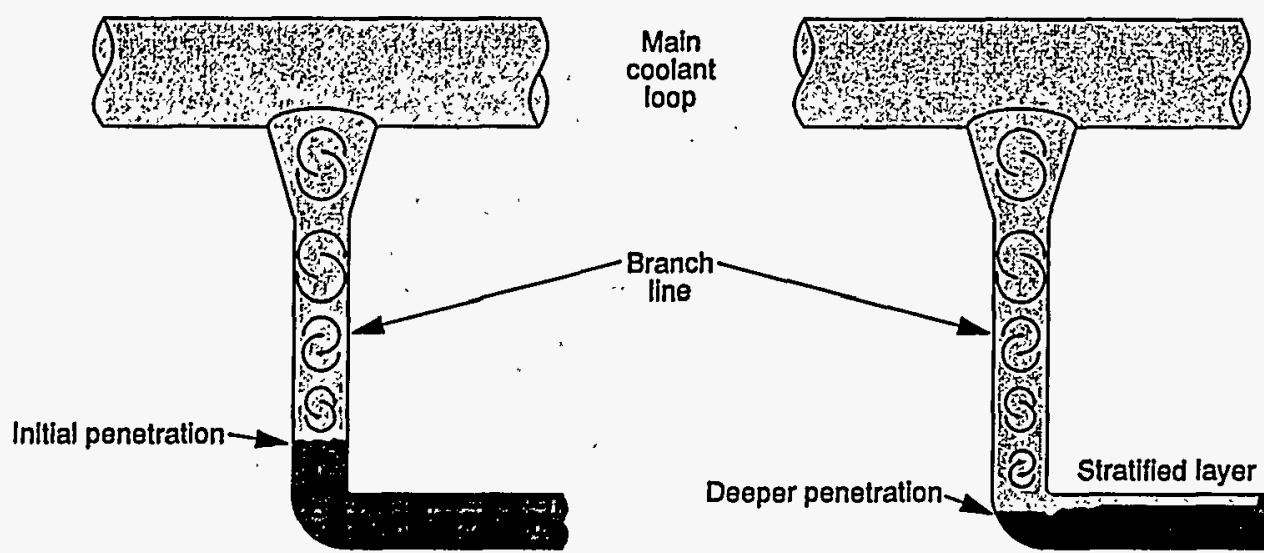

(a) Initial penetration of turbulence is confined to vertical section.

(b) Deeper penetration causes stratification in the horizontal section.

Z010WHF-1205-00

Figure 47. A change in the penetration depth of turbulence from power variations can cause thermal stratification and cycling in a branch line (Martin 1993). 
Thermal cycling could cause similar cracking in the auxiliary feedwater piping where it connects to the main feedwater line. However, such cracking of PWR auxiliary feedwater lines has not been reported. It is also not certain that similar thermal cycling could take place in the auxiliary feedwater line in the absence of any valve leakage. Monitoring of the temperatures at the outside surface of the auxiliary feedwater piping would probably indicate whether thermal stratification is taking place and thermal cycling is occurring.

\subsection{Flow-Accelerated Corrosion}

As discussed in Section 6, flow-accelerated corrosion has caused wall thinning in carbon steel piping leading to costly repair and replacement and, in some cases, catastrophic ruptures. Flowaccelerated corrosion also causes damage to the steam generator tubes, not directly but indirectly. The corrosion products are deposited as sludge on the tubesheet and contribute to denting and crevice corrosion of the tubes.

\subsubsection{Flow-Accelerated Corrosion Phenomena}

A thin layer of porus iron oxide [mostly magnetite $\left(\mathrm{Fe}_{3} \mathrm{O}_{4}\right)$ ] forms on the inside surface of carbon steel feedwater piping exposed to deoxygenated water in the temperature range of about 95 to $260^{\circ} \mathrm{C} \mathrm{(200}$ to $500^{\circ} \mathrm{F}$ ). Generally, this layer protects the underlying piping from the corrosive environment and limits further corrosion. However, the magnetite layer may be dissolved at the oxidewater interface and be replaced by new iron oxide formed at the metal-oxide interface, resulting in material removal and thinning of the piping. The corrosion process is strongly influenced by the fluid velocity, chemistry and temperature, piping configuration, and alloy content of the steel as discussed below. This process is called flowaccelerated corrosion.

Flow-accelerated corrosion is often called erosioncorrosion in the United States. But, this process is primarily a corrosion process enhanced by chemi- cal dissolution and mass transfer, rather than a mechanical process involving removal of the oxide layer by erosion or cavitation. No evidence of the removal of surface oxide by mechanical shear forces has been found during any macroscopic or microscopic examination of the damaged inside surfaces of the feedwater piping. Hence, the term flow-accelerated corrosion is more appropriate for the observed wall thinning of carbon steel piping exposed to deoxygenated feedwater (Chexal et al. 1996). Laboratory results show that the fluid velocities associated with the removal of the oxide layer by mechanical processes are higher than those associated with the dissolution of an oxide layer. Also, the kinetics of metal removal by a mechanical process are either quasi-linear or nonlinear, whereas the kinetics of metal removal by an oxide dissolution process are linear (that is, corrosion rate is constant in time). The corrosion rates (wall thinning rates) observed in the field are essentially constant when the influencing factors do not vary.

The flow-accelerated corrosion process is an extension of the generalized carbon steel corrosion process in stagnant water. In stagnant water, the carbon steel corrosion rate is low and decreases parabolically with time due to the formation of a protective oxide film at the surface. Flowaccelerated corrosion takes place at low flow velocities and, as mentioned earlier, the corresponding corrosion rate is constant. The difference between generalized corrosion and flowaccelerated corrosion is the effect of water flow at the oxide-feedwater interface.

The flow-accelerated corrosion process may be explained as follows. First, iron hydroxides are generated at the metal-water interface according to the reaction:

$$
\mathrm{Fe}+2 \mathrm{H}_{2} \mathrm{O} \rightarrow \mathrm{Fe}(\mathrm{OH})_{2}+\mathrm{H}_{2} \text {. }
$$

Then, a porous iron oxide layer is formed according to the reaction:

$$
3 \mathrm{Fe}(\mathrm{OH})_{2} \rightarrow \mathrm{Fe}_{3} \mathrm{O}_{4}+\mathrm{H}_{2}+2 \mathrm{H}_{2} \mathrm{O} \text {. }
$$


The flow-accelerated corrosion phenomena then follows a simple two-step process which is illustrated in Figure 48 (Remy and Bouchacourt 1992). The first step consists of production of soluble ferrous ions and their accumulation at the oxidewater interface and the second step consists of mass transfer of these ions into the bulk coolant. The ferrous ions are produced by two different reactions: (a) base metal oxidation at the metaloxide interface and diffusion of the ferrous ions through the porous oxide layer to the oxide-water interface, and (b) reduction of the magnetite layer at the oxide-water interface. Ferrous ion production is a steady state corrosion process which depends on the $\mathrm{pH}$ of the water, hydrogen pressure, temperature, and the oxide layer thickness (inversely proportional to the thickness). The oxide layer thickness, usually less than $1 \mu \mathrm{m}$, remains constant during a steady-state flow-accelerated corrosion process.

In the second step, the flowing water removes the soluble ferrous ions by a convective mass transfer mechanism, which is a diffusion gradient driven process. Generally, the concentration of ferrous ions in the bulk water is very low compared to their concentration at the oxide-water interface. Therefore, it is assumed that the ferrous ions pre- sent at the oxide-water interface can diffuse very rapidly into the solution. If the ferrous ion production is faster than the mass transfer rate, the flowaccelerated corrosion process is a convective diffusion-controlled process, and the corrosion rate increases with the increase in the fluid velocity. Each factor that affects the flow-accelerated corrosion process influences the process through one of these two steps. These factors are discussed later in the section.

A similar corrosion process causes wall thinning of carbon steel piping exposed to wet steam; this process is called two-phase flow-accelerated corrosion. However, if the piping is exposed to dry or superheated steam, no flow-accelerated corrosion takes place; a liquid phase must be present for flow-accelerated corrosion damage to occur. Corroded surfaces produced by singlephase flow-accelerated corrosion have a different appearance than those formed by the two-phase flow-accelerated corrosion. When the single-phase flow-accelerated corrosion rate for a large-diameter piping is high, the corroded surface is characterized by overlapping horseshoe pits that give an orange peel appearance. The corroded surface of a large diameter piping exposed to two-phase flow has a well known tiger striping appearance. Sur-

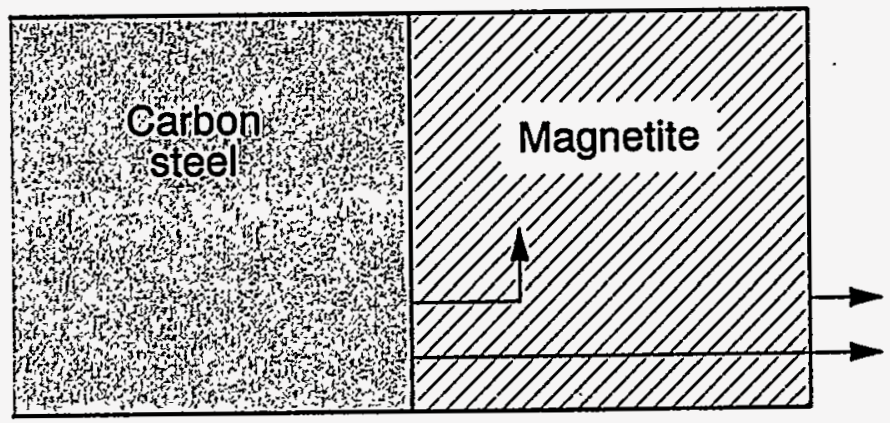

$\mathrm{Fe}$

$\mathrm{Fe}_{3} \mathrm{O}_{4}$ Oxidation

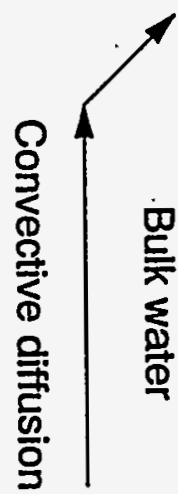

$\mathrm{Fe}++$ Reduction

Figure 48. The flow-accelerated corrosion model (Remy and Bouchacourt 1992). Copyright Elsevier Science Publishers; reprinted with permission. 
face examinations of severely corroded carbon steel components have shown that the thickness of the oxide film is not uniform. Scanning electron microscope examinations of corroded surfaces show a selective attack on the pearlite constituent of the carbon steel microstructure. This selective attack produces micropitting which has been considered to be the initial step in the formation of horseshoe pits and tiger striping (Chexal et al. 1996). This report discusses only single-phase flow-accelerated corrosion, which is simply referred to as flow-accelerated corrosion.

The characteristics of the piping damage caused by flow-accelerated corrosion are different than that caused by thermal fatigue. Wall-thinning caused by flow-accelerated corrosion typically occurs over a broad area of the inside piping surface, whereas a thermal fatigue crack affects a relatively local area of the surface. A component damaged by flow-accelerated corrosion will eventually become too thin to support normal loads and may fail under normal operating pressure; a large fitting might fail catastrophically without any warning. A throughwall crack caused by thermal fatigue will generally leak long before the component ruptures. However, a large overload may cause a pipe with fatigue cracks to fail catastrophically with no prior leakage.

Sites susceptible to flow-accelerated corrosion are found throughout the feedwater system, whereas sites susceptible to thermal fatigue cracking are found in those portions of the piping where stratified flows are present and are generally well identified. Several factors affect the flowaccelerated corrosion rates and, therefore, it was difficult to identify the sites susceptible to this corrosion process. Since the Surry incident in 1986, significant efforts have been spent in developing models for identifying these sites and estimating flow-accelerated corrosion rates.

\subsubsection{Factors Affecting Flow-Accelerated Corrosion}

Flow-accelerated corrosion tests have been conducted at several British, French, and German laboratories to identify the factors affecting the corrosion rates (rate of metal loss) and to provide data for development of empirical models to estimate the rates (Chexal and Jones 1988, Chexal and Horowitz 1995). Evaluation of test results and data from operating plants have identified several factors that affect the flow-accelerated corrosion rates. These factors may be divided in three groups: (a) hydrodynamic variables - fluid velocity, pipe roughness, and piping configuration (geometry of the flow path); (b) metallurgical variables - chemical composition including weight percentage of chromium, molybdenum and copper in the steel; and (c) environmental variables coolant temperature and water chemistry including dissolved oxygen, ferrous ion concentration, and metallic impurities in water, $\mathrm{pH}$, and the amines used for $\mathrm{pH}$ control. Each factor is discussed in the following subsections, and several calculated results using the Chexal-Horowitz model are presented. The calculated results are for the following parameters, with some variations: 102-mm (4-in.) diameter carbon steel elbow, $7 \mathrm{ppb}$ oxygen content, $6.1-\mathrm{m} / \mathrm{s}(20-\mathrm{ft} / \mathrm{s})$ flow velocity, room temperature $\left[25^{\circ} \mathrm{C}\left(77^{\circ} \mathrm{F}\right)\right] \mathrm{pH}$ of 7 , and 0.03 wt $\%$ of chromium, molybdenum, and copper content; the variations are noted as appropriate. The $\mathrm{pH}$ level at room temperature is also referred to as cold $p H$.

Hydrodynamic Variables. The hydrodynamic variables include fluid velocity, pipe roughness, and piping configuration (geometry of flow path). These variables affect the rate of mass transfer of the iron ions and other corrosion products to the bulk coolant and thus affect the flow-accelerated corrosion rate. Fluid velocity affects the mass transfer. At a relatively low flow velocity, the corrosion rate is controlled by the rate of mass transfer, whereas at higher velocity (still lower than the critical velocity above which metal removal by mechanical process takes place) the mass transfer rate is higher and the corrosion rate is controlled by the chemical reactions at the oxidecoolant and metal-oxide interfaces. Flowaccelerated corrosion is less frequently observed in straight lengths of pipe free from hydrodynamic disturbances unless the bulk fluid velocity is high. Laboratory studies of the effect of bulk flow velocities, which varied from 2 to $18 \mathrm{~m} / \mathrm{s}$ (6.6 to $59 \mathrm{ft} / \mathrm{s}$ ), on the corrosion of carbon steel in $150^{\circ} \mathrm{C}$ $\left(300^{\circ} \mathrm{F}\right)$ circulating water show that the corrosion 
rate increases with an increase in the flow rate and, for a given flow rate, the corrosion rate is about constant. Figure 49 shows how the flowaccelerated corrosion rates for straight tube samples placed downstream of an orifice varied with temperature and flow rate (Delp et al. 1985). The samples were tested at Central Electric Research Laboratories (CERL) in the United Kingdom. The $\mathrm{pH}$ level was in the range of 8.5 to 9.2. The flow rate ranged from 227 to $983 \mathrm{~kg} / \mathrm{h} \mathrm{Cl}$ to $5 \mathrm{gpm})$ through the $8.33-\mathrm{mm}(0.33-\mathrm{in}$.) diameter tube, with flow velocities of 1.2 to $5.8 \mathrm{~m} / \mathrm{s}$ (4 to 19 $\mathrm{ft} / \mathrm{s})$. The corresponding maximum corrosion rates ranged from about 0.4 to $4.1 \mathrm{~mm} / \mathrm{yr}(0.016$ to $0.16 \mathrm{in./yr)}$.

The flow accelerated corrosion rates are influenced by two other factors that affect the local flow velocity: pipe roughness and piping configuration. Roughnes's in commercial pipes is a consequence of the manufacturing process or a result of plant operation. A rough surface produced by the flowaccelerated corrosion process can be very damaging. The micropits formed by the initial selective attack on the carbon steel microstructure grow until they touch, and thus the surface becomes rough. The dependence of mass transfer on the velocity is greater for a rough surface than for a smooth surface.

The variable piping configuration takes into account the hydrodynamic disturbances (elbows, tees, branch connections, reducers, valves, flow control orifices, etc.) that produce high local fluid velocities and result in a further increase in mass transfer. Experiments have shown that local-flow velocities in elbows can be two to three times the bulk-flow velocities (Bosnak 1987, USNRC 1987c). The results of the Chexal-Horowitz model showing the effect of different piping configura-

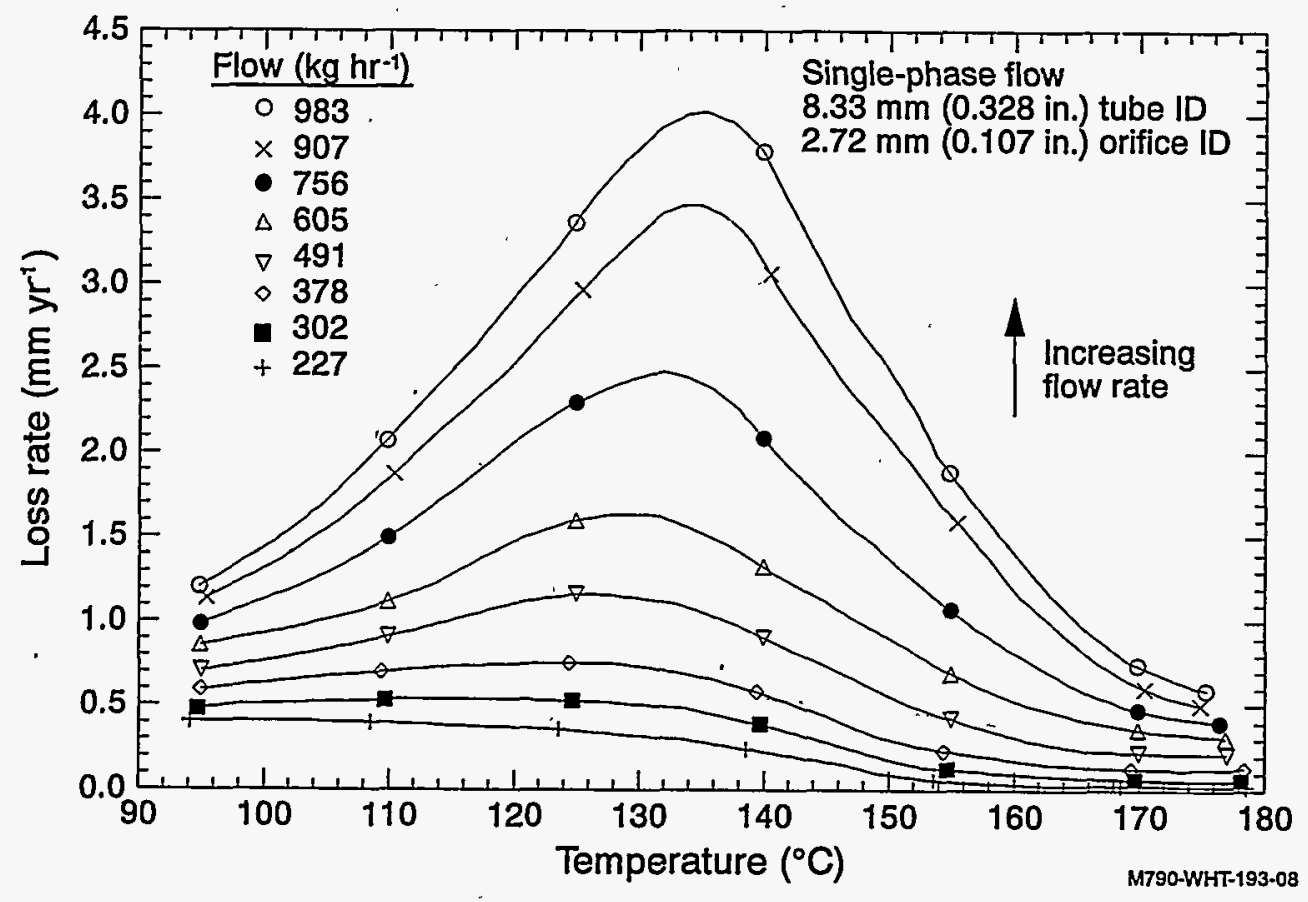

Figure 49. Flow and temperature dependence of flow-accelerated corrosion rates (Delp et al. 1985). 
tions on flow-accelerated corrosion rates are presented in Figure 50. The maximum corrosion rate for a 90-degree elbow configuration is about 2.5 times greater than that for a straight pipe; the rate is $3.8 \mathrm{~mm} / \mathrm{yr}(0.15 \mathrm{in} / \mathrm{yr})$ for an elbow, and $1.5 \mathrm{~mm} / \mathrm{yr}(0.06 \mathrm{in} / \mathrm{yr})$ for a straight pipe. Geometric discontinuities at the joints between the $\mathrm{J}$-tubes and feedring piping have caused significant flow-accelerated corrosion damage, as shown in Figure 37(a).

Figure 51 illustrates the influence of fluid velocity on the flow-accelerated corrosion rates on the inside surfaces of a 102-mm (4-in.) diameter, 90-degree carbon steel elbow, as predicted by the Chexal-Horowitz model. As the velocity increases from 1.50 to $9.0 \mathrm{~m} / \mathrm{s}$ (5 to $30 \mathrm{f} / \mathrm{s})$, the corrosion rate increases by a factor of three, from about 1.65 to $5.0 \mathrm{~mm} / \mathrm{yr}(0.065$ to $0.195 \mathrm{in} . / \mathrm{yr})$. The maximum corrosion rate occurs at about $150^{\circ} \mathrm{C}$ $\left(300^{\circ} \mathrm{F}\right)$. When the fluid velocity is zero, the flowaccelerated corrosion rate is zero or very small. Therefore, flow-accelerated corrosion damage has not been reported in the auxiliary feedwater piping in which the fluid is typically stagnant during normal operation (Mode 1) and cold when flowing during plant startup, hot standby, and shutdown, and during design basis events. However, in some plants with preheaters, a small percentage of the main feedwater is bypassed through the auxiliary feedwater line during normal operation as shown in Figure 9. Flow-accelerated corrosion damage has been reported in these portions of the auxiliary feedwater line exposed to flowing hightemperature fluid during normal operation (see Section 6.4.1).

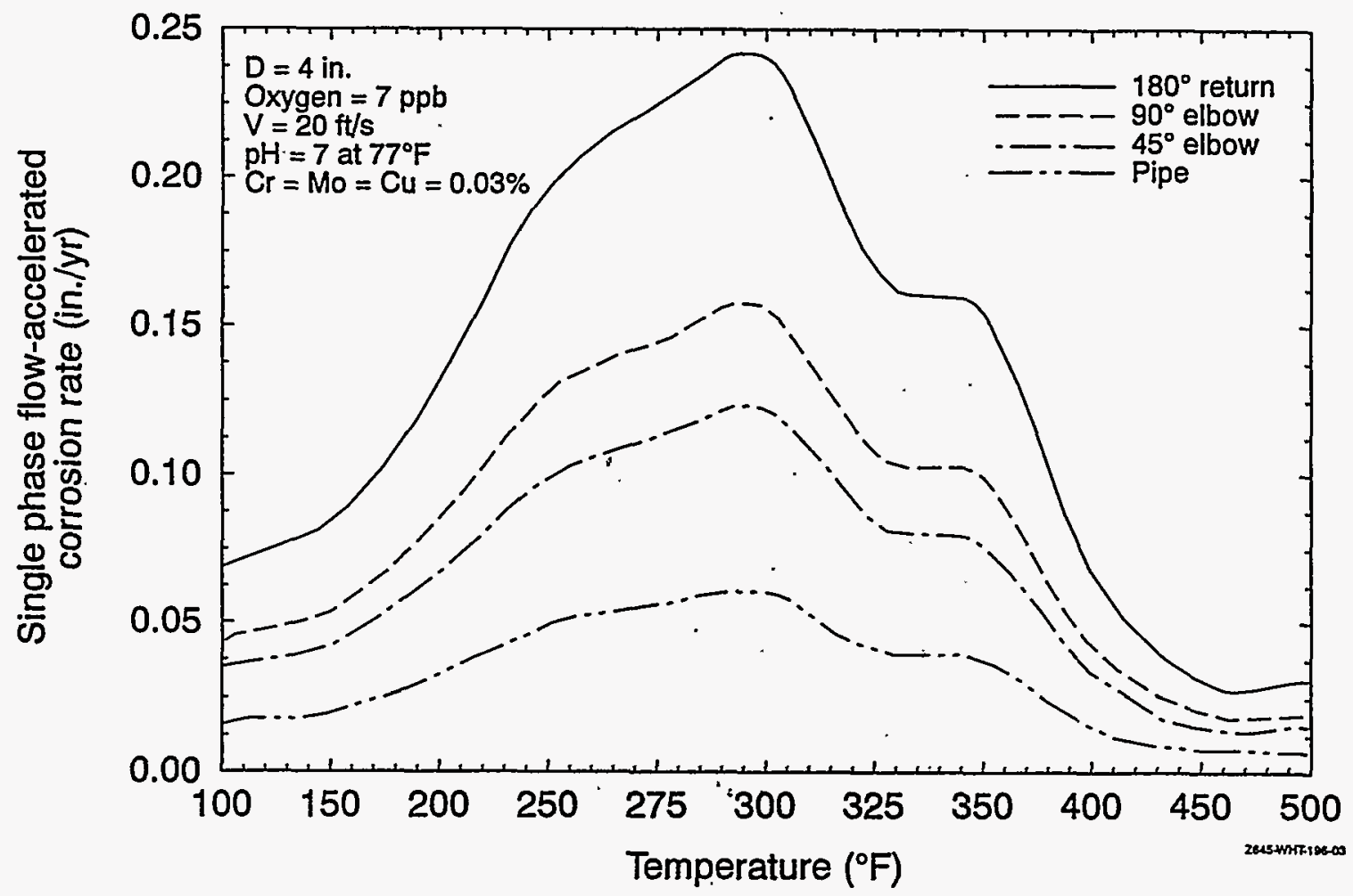

Figure 50. Influence of fluid temperature on flow-accelerated corrosion rates for carbon steel fittings estimated using the Chexal-Horowitz model (Chexal and Horowitz 1995). Copyright American Society of Mechanical Engineers; reprinted with permission. [ $1 \mathrm{in} .=25.4 \mathrm{~mm} ; 1 \mathrm{ft} / \mathrm{s}=0.3048 \mathrm{~m} / \mathrm{s} ; 0.5556\left({ }^{\circ} \mathrm{F}-32\right)=$ ${ }^{\circ} \mathrm{C}$ ]. 


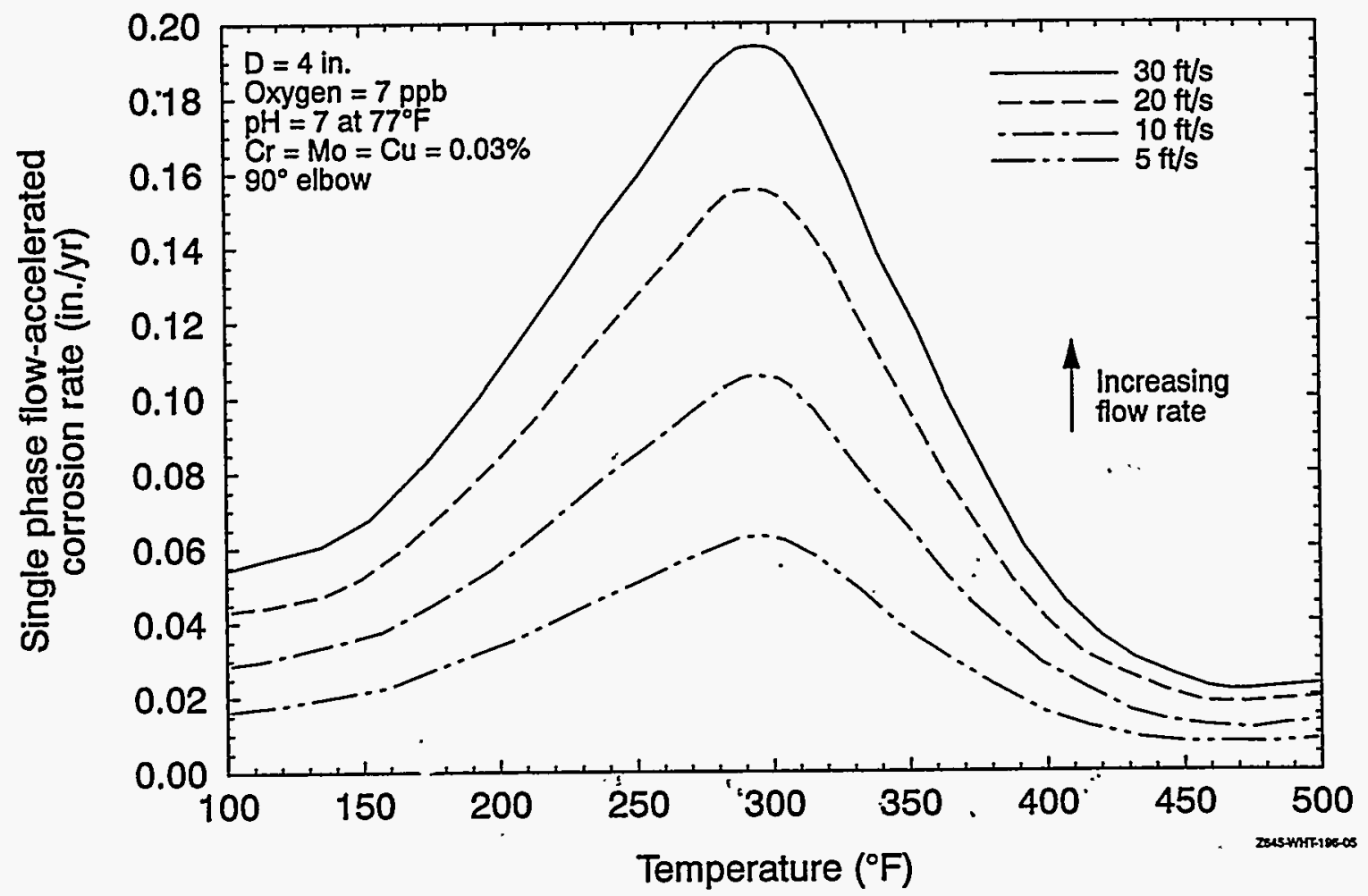

Figure 51. Influence of fluid velocity on flow-accelerated corrosion rates for a 90-degree carbon steel elbow, estimated using the Chexal-Horowitz model (Chexal and Horowitz 1995). Copyright American Society of Mechanical Engineers; reprinted with permission. $\left[1 \mathrm{in} .=25.4 \mathrm{~mm} ; 1 \mathrm{ft} / \mathrm{s}=0.3048 \mathrm{~m} / \mathrm{s} ; 0.5556\left({ }^{\circ} \mathrm{F}-32\right)=\right.$ $\left.{ }^{\circ} \mathrm{C}\right]$.

Metallurgical Variables. Trace amounts of chromium, molybdenum, and copper in carbon steel provide resistance to flow-accelerated corrosion. The corrosion rate is most sensitive to the weight percent ( $w t \%)$ of the chromium in the steel. Figure 52 illustrates flow-accelerated corrosion rate dependance on chromium content of the base metal as predicted by the Chexal-Horowitz model for a 90-degree carbon steel elbow subject to specific hydrodynamic and water chemistry variables. The maximum rate is equal to about 3.9 $\mathrm{mm} / \mathrm{yr}(0.155 \mathrm{in} . / \mathrm{yr})$ for $0.03 \mathrm{wt} \% \mathrm{Cr}$ and equal to about $0.4 \mathrm{~mm} / \mathrm{yr}(0.016 \mathrm{in} . / \mathrm{yr})$ for $0.50 \mathrm{wt} \% \mathrm{Cr}$. Thus a small amount of chromium significantly reduces the flow-accelerated corrosion rate. Wall thinning measurements for carbon steel feedrings and thermal sleeves at the four steam generators of Diablo Canyon Unit 2 indicate that no wall thinning was found in components that had a chromium content greater than $0.1 \mathrm{wt} \%$ (Thailer, Dalal, and Goyette 1995), which is also supported by the other field experience data (Chexal et al. 1996). The presence of chromium increases the stability of the oxide layer and reduces its solubility in deoxygenated feedwater.

Industry experience indicates that lightly alloyed steel such as 1 1/4 Cr-1/2Mo steel (SA-335, Grade P11), 2 1/4Cr-1Mo steel (SA-335, Grade P22), Type 304 stainless steel and Alloy 600 will provide full protection against flow-accelerated corrosion, and are now being used in replacing the carbon steel components. Flow-accelerated corrosion rates for these steels are significantly lower than that for carbon steel with a nominal composition (0 wt $\% \mathrm{Cr}$ and $0 \mathrm{wt} \% \mathrm{Mo}$ ). The results of the Chexal-Horowitz model show that the corrosion rate for Grade P11 steel is 39 times lower than that for the unalloyed carbon steel, for Grade P22 steel it is 76 times lower, and for Type 304 stainless steel it is more than 250 times lower (Chexal et al. 1996). 


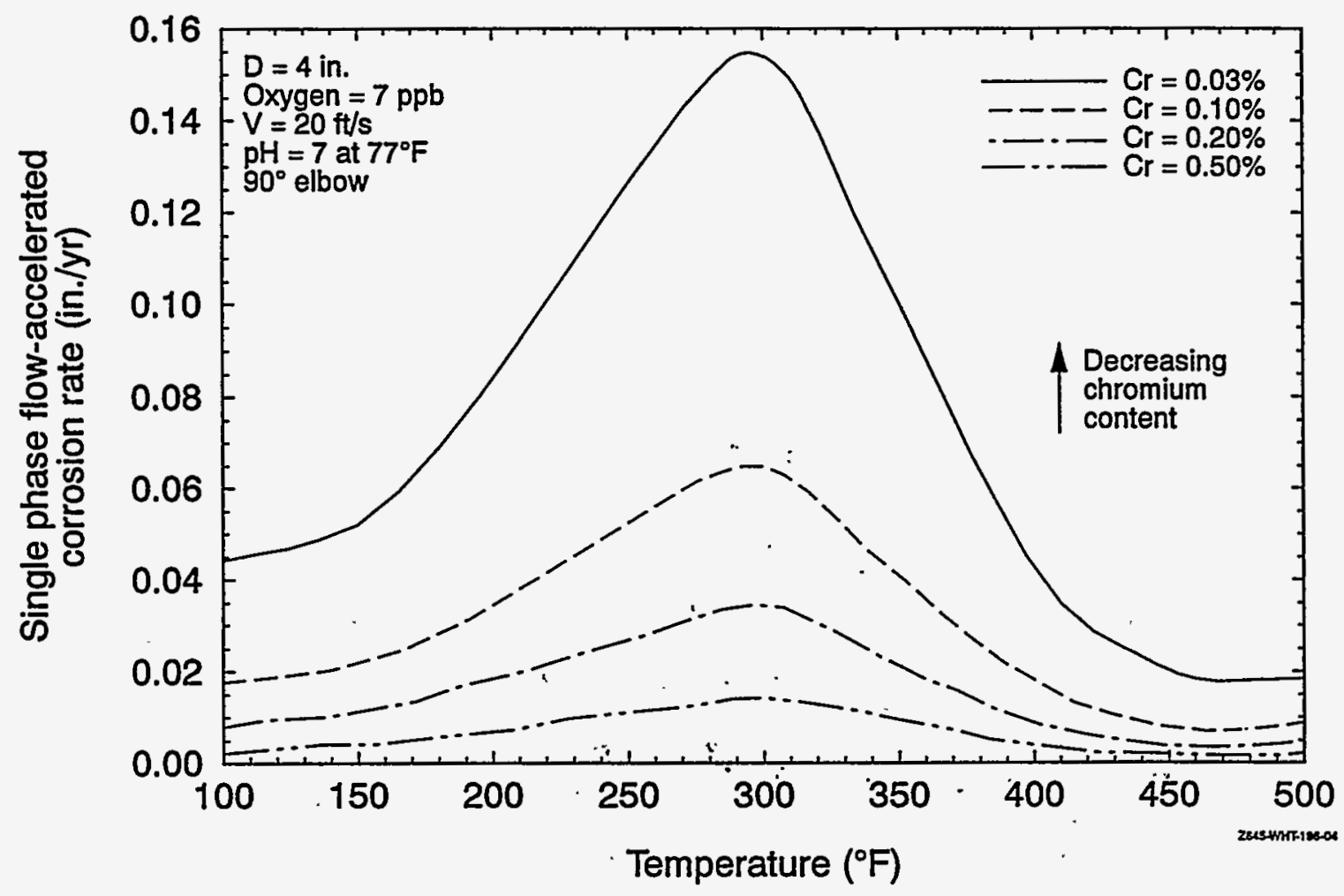

Figure 52. Influence of chromium content on flow-accelerated corrosion rates for a 90-degree carbon steel elbow, estimated using the Chexal-Horowitz model (Chexal and Horowitz 1995). Copyright American Society of Mechanical Engineers; reprinted with permission. [ $1 \mathrm{in} .=25.4 \mathrm{~mm} ; 1 \mathrm{ft} / \mathrm{s}=0.3048 \mathrm{~m} / \mathrm{s} ; 0.5556\left({ }^{\circ} \mathrm{F}-32\right)$ $\left.={ }^{\circ} \mathrm{C}\right]$.

Environmental Variables. Two main environmental variables that affect flowaccelerated corrosion rate are coolant temperature and water chemistry. The water chemistry includes dissolved oxygen, ferrous ion concentration, metallic impurities, and cold $\mathrm{pH}$ level. This section discusses the effect of these parameters on the flow accelerated corrosion of carbon steel components in the single phase feedwater system. Then it discusses how the optimum water chemistry for the PWR secondary water-steam system is achieved.

The fluid temperature influences both the ferrous ion production and the mass transfer of these ions into the bulk water (Remy and Bouchacourt 1992).
As the temperature increases, the ferrous ion concentration at the oxide-water interface decreases almost linearly. On the other hand, as the temperature increases, the ferrous ion diffusivity into the coolant increases, resulting in a mass transfer coefficient which increases about linearly. The resulting corrosion rate variation with temperature is a bell-shaped curve as shown in Figures 53 and several other figures in this section; the temperature at which the maximum corrosion rate occurs depends upon the other environmental conditions. For most feedwater piping conditions, the maximum corrosion rate occurs at about $150^{\circ} \mathrm{C}\left(300^{\circ} \mathrm{F}\right)(\mathrm{Chexal}$ and Horowitz 1995). 


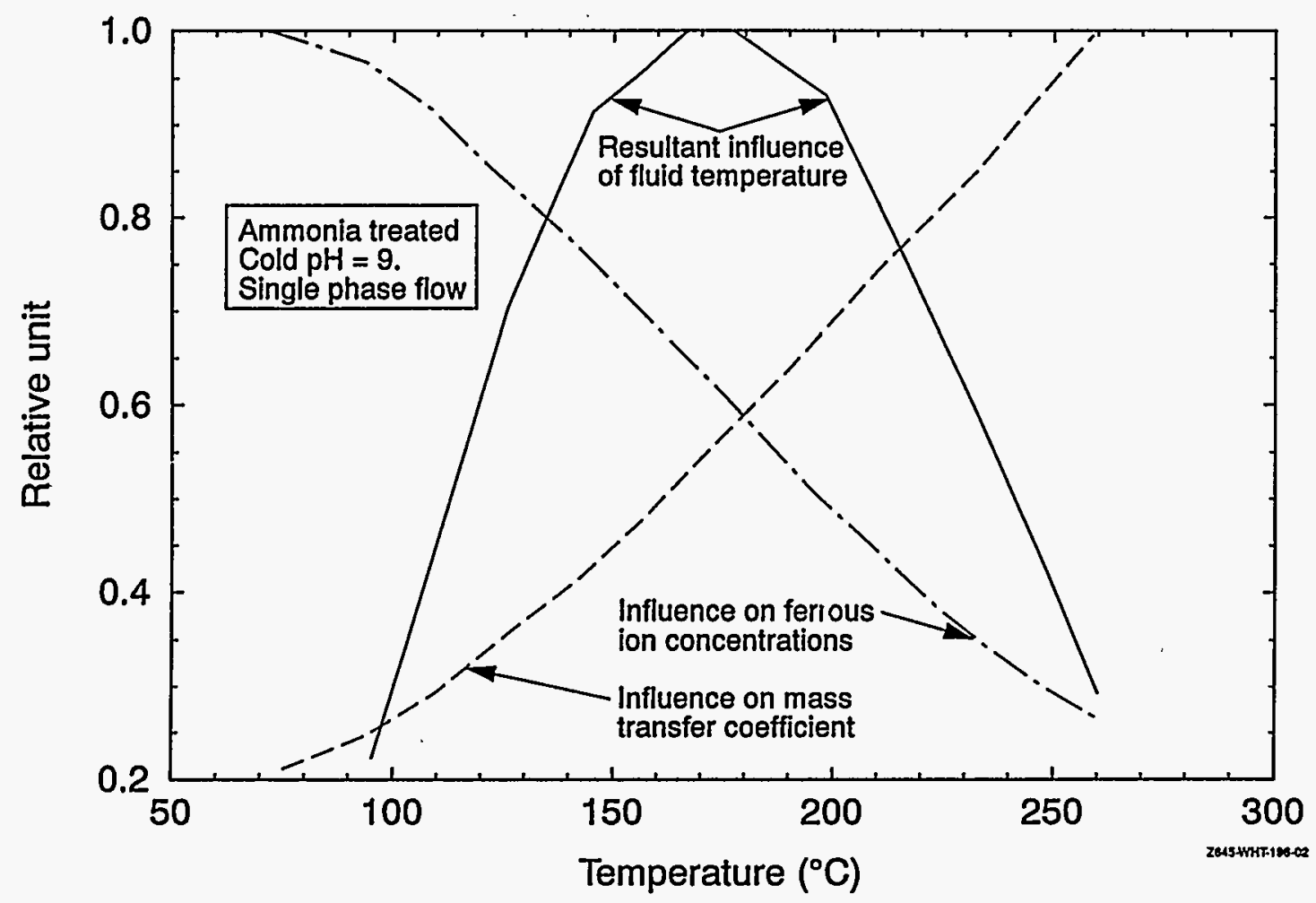

Figure 53. The calculated influence of fluid temperature on the ferrous ion concentration and on mass transfer of ferrous ions (Remy and Bouchacourt 1992). Copyright Elsevier Science Publishers; reprinted with permission.

The flow-accelerated corrosion rate varies inversely with the level of dissolved oxygen in the fluid. As the level of oxygen increases above a threshold value, a less porus oxide layer of hematite, instead of magnetite, is formed. Because the solubility of hematite in the feedwater is several orders of magnitude lower than that of magnetite, the flow-accelerated corrosion rate decreases significantly. Some laboratory test results show that the threshold value for dissolved oxygen is less than $15 \mathrm{ppb}$ (Remy and Bouchacourt 1992). The corresponding results using the Chexal-Horowitz model are presented in Figure 54, which shows a reduction in the maximum flow-accelerated corrosion rate from about 3.2 to $0.9 \mathrm{~mm} / \mathrm{yr}(0.125$ to $0.035 \mathrm{in} . / \mathrm{yr})$ as dissolved oxygen content increased from 10 to $30 \mathrm{ppb}$.
Ferrous ion concentration and metallic impurities in the water affects the flow-accelerated corrosion rate. The increase in the ferrous ion concentration in the bulk fluid reduces the mass transfer of ferrous ions from the oxide-coolant interface to the bulk coolant. An increased ferrous ion concentration can reduce or suppress flowaccelerated corrosion when the corrosion process is controlled by mass transfer. The metallic impurities such as metallic copper, precipitate into the pores of the oxide and reduce the flowaccelerated corrosion rate for a short time period, then the corrosion rates return to the original value. The presence of copper in the feedwater can be a result of corrosion of copper alloys used in feedwater system components such as condenser tubes and feedwater heater tubes (Chexal et al. 1996). 


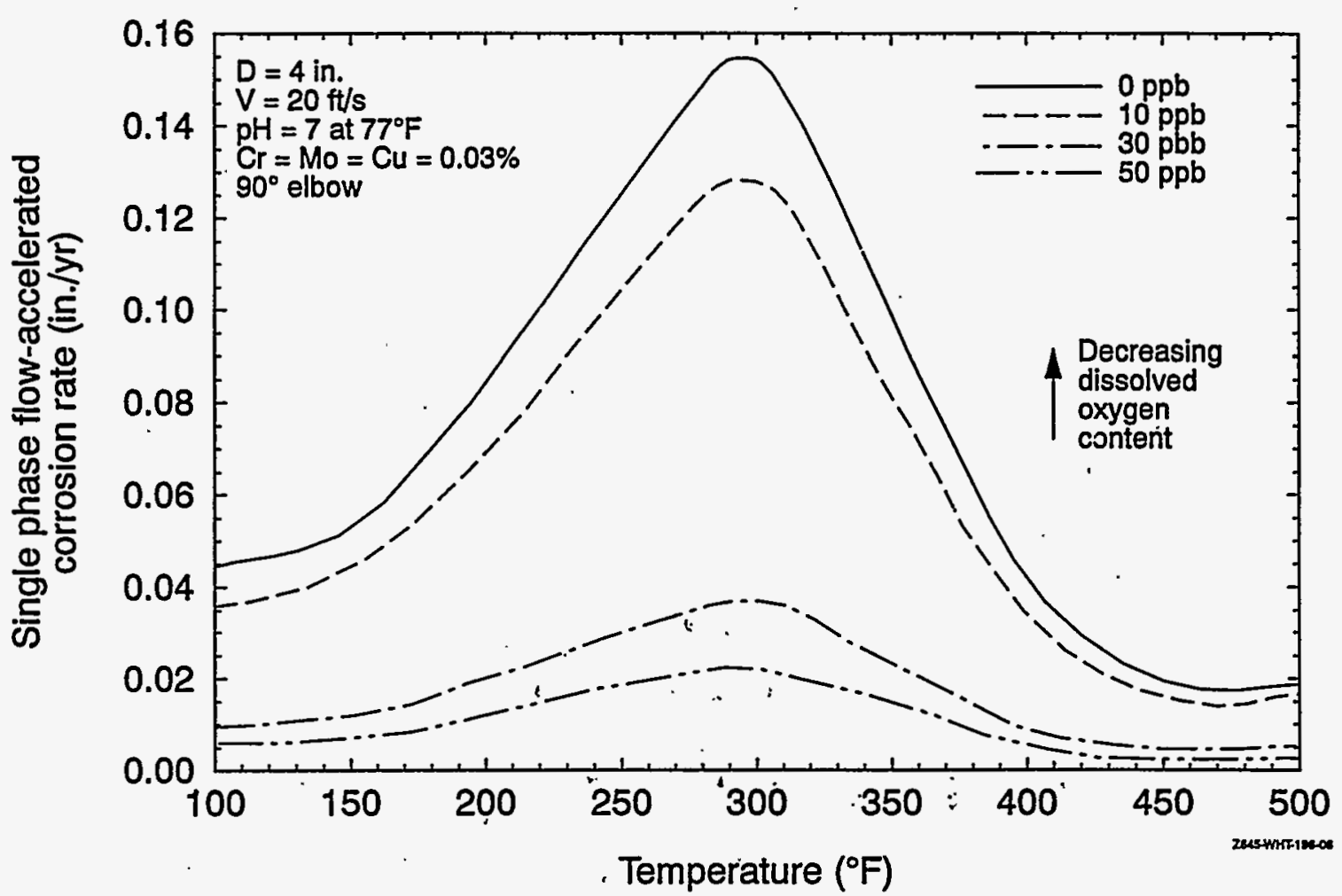

Figure 54. Influence of dissolved oxygen content on flow-accelerated corrosion rates for a 90-degree carbon steel elbow, estimated using the Chexal-Horowitz model (Chexal and Horowitz 1995). Copyright American Society of Mechanical Engineers; reprinted with permission. $\left[1 \mathrm{in} .=25.4 \mathrm{~mm} ; 1 \mathrm{ft} / \mathrm{s}=0.348 \mathrm{~m} / \mathrm{s} ; 0.5556\left({ }^{\circ} \mathrm{F}\right.\right.$ $\left.-32)={ }^{\circ} \mathrm{C}\right]$.

Flow-accelerated corrosion rates vary by an order of magnitude over the cold pH range of 8.5 to 9.5 , which is typical for feedwater systems (Shack and Jonas 1988). Figure 55 shows the effect of cold $\mathrm{pH}$ on the solubility of magnetite $\left(\mathrm{Fe}_{3} \mathrm{O}_{4}\right)$ in deoxygenated water over the temperature range of 25 to $250^{\circ} \mathrm{C}\left(77\right.$ to $\left.482^{\circ} \mathrm{F}\right)$ (Tremaine et al. 1977). The solubility of magnetite directly correlates with the flow-accelerated corrosion rate. First the solubility decreases as the cold $\mathrm{pH}$ increases from 3 to a certain value, which depends on the temperature, in the range of 10 to 12 , then the solubility increases as the cold $\mathrm{pH}$ increases. For example, at $150^{\circ} \mathrm{C}\left(300^{\circ} \mathrm{F}\right)$, the solubility decreases from $30 \mathrm{ppm}$ of ferrous ion concentration to $0.001 \mathrm{ppm}$ as the cold $\mathrm{pH}$ increases from 3 to 11 . At this tem- perature, the flow-accelerated corrosion rate increases rather dramatically as the $\mathrm{pH}$ is reduced below or increased above about 11.0. Figure 56 shows the dependence of the flow-accelerated corrosion rate on the cold $\mathrm{pH}$ as predicted using the Chexal-Horowitz model. The maximum flowaccelerated corrosion rate decreases from 1.7 to $0.38 \mathrm{~mm} / \mathrm{yr}$ ( 0.0675 to $0.015 \mathrm{in} . / \mathrm{yr})$ as the cold $\mathrm{pH}$ increases from 8.7 to 9.4 .

The optimum $\mathrm{pH}$ and water chemistry in the PWR secondary steam-water system are generally achieved by the addition of reagents such as ammonia, morpholine, and ethanolamine in the demineralized water. These amines are volatile and, therefore, maintain a slightly alkaline $\mathrm{pH}$ in 


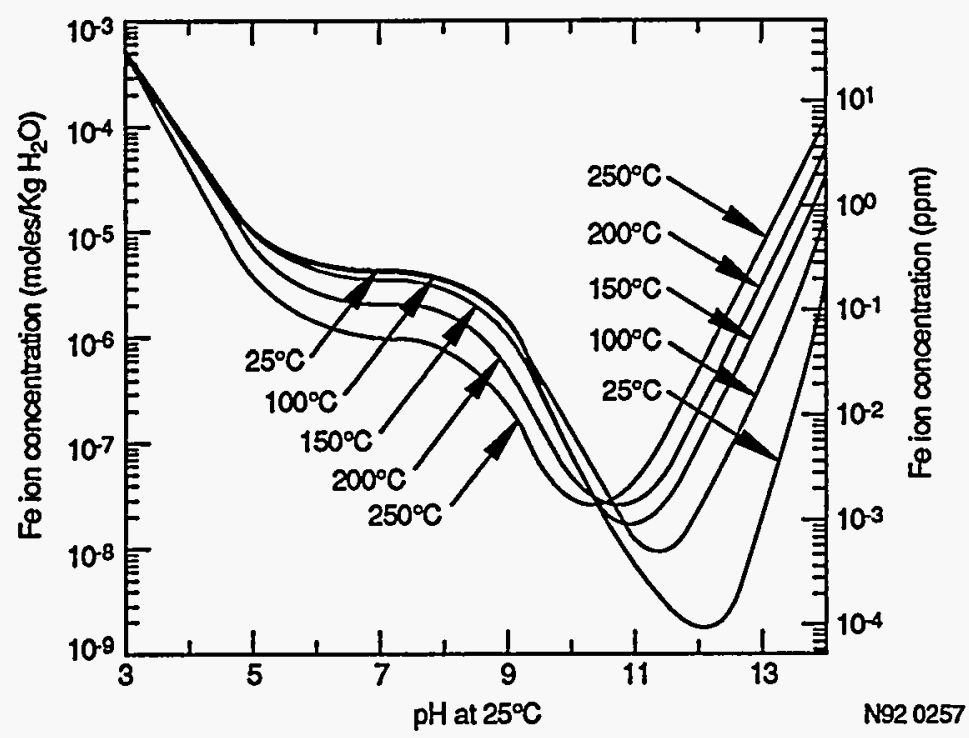

Figure 55. Effect of cold pH on solubility of magnetite in deoxygenated water (Tremaine et al. 1977). Copyright Elsevier Science Publishers; reprinted with permission.

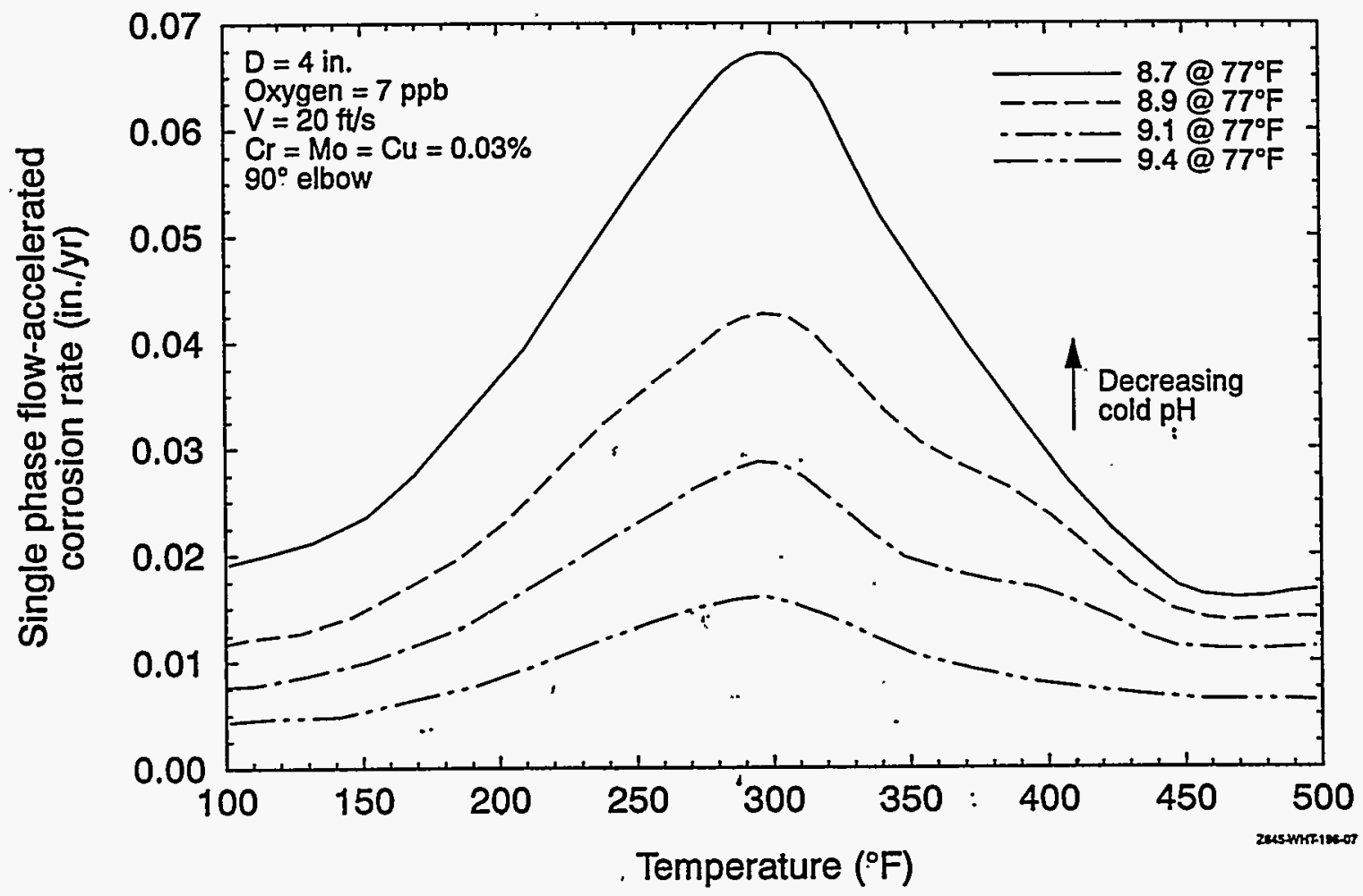

Figure 56. Influence of cold $\mathrm{pH}$ on flow-accelerated corrosion rates for a 90-degree carbon steel elbow, estimated using the Chexal-Horowitz model (Chexal and Horowitz 1995). Copyright American Society of Mechanical Engineers; reprinted with permission. $\left[1\right.$ in. $=25.4 \mathrm{~mm} ; 1 \mathrm{ft} / \mathrm{s}=0.348 \mathrm{~m} / \mathrm{s} ; 0.5556\left({ }^{\circ} \mathrm{F}-32\right)=$ ${ }^{\circ} \mathrm{C}$. 
both the single-phase and two-phase regimes of the secondary system and reduce the flow-accelerated corrosion damage in the entire system. However, the amount of partitioning into the liquid and steam phases is different for the various amines. Therefore, different concentrations of these amines are required to obtain a desired $\mathrm{pH}$ at the operating temperature. Different concentrations of amines correspond to different cold $\mathrm{pH}$ (Chexal et al. 1996). In addition to the amines, hydrazine is added as a reducing agent.

The selection of the $\mathrm{pH}$ and water chemistry is mainly a compromise between the acceptable corrosion of piping and components made of carbon steel and copper alloys. Corrosion of carbon steel is undesirable for three reasons: (1) the wall thinning of the piping and vessels by flowaccelerated corrosion, (2) the corrosion products transported to the steam generator, and (3) the fouling of condensate polishers. Corrosion of copper alloys is undesirable for three similar reasons: (1) the shortened life of the copper based components, (2) the transport of copper and oxygen to the steam generator, and (3) the fouling of the condensate polishers.

Systems with an absence of copper alloy materials can maintain a higher cold $\mathrm{pH}$ level to reduce the flow-accelerated corrosion of carbon steel components. If ammonia is used for $\mathrm{pH}$ control in these PWR feedwater systems, the cold $\mathrm{pH}$ should be increased, at least up to 9.7, to avoid flow-accelerated corrosion (Nordmann and Fiquet 1996). However, if the condensate polishers are present and continuously in operation, the regeneration frequency will be high. Therefore, use of ammonia with a cold $\mathrm{pH}$ of 9.7 may be acceptable only for plants without copper alloys and without condensate polishers being continuously in operation.

For feedwater systems with copper alloy materials in the condensers and certain water heaters, a cold $\mathrm{pH}$ level in the range of 8.8 to 9.2 should be maintained to prevent excessive copper pickup. Morpholine is widely used in these systems (all French PWRs and several U.S. PWRs) to maintain a cold $\mathrm{pH}$ in the range of 9.1 to 9.3 , provided the condensate polishers are absent. Ammonia is not used because it promotes corrosion of the copper alloy materials. Along with the use of morpholine, hydrazine is used to lower the dissolved oxygen content in the feedwater. However, the concentration of hydrazine is kept low because thermal decomposition of hydrazine generates ammonia (Bouchacourt et al. 1994).

As compared to ammonia, a smaller molar concentration of morpholine and a lower cold $\mathrm{pH}$ provide the same desired $\mathrm{pH}$ at the operating temperature. For example, to obtain a pH of 6.82 in the two-phase flow at an operating temperature of $175^{\circ} \mathrm{C}\left(347^{\circ} \mathrm{F}\right)$, use of ammonia will require a cold $\mathrm{pH}$ of 10.0 , whereas use of morpholine will require a cold $\mathrm{pH}$ of 9.3 . In addition, for the same cold $\mathrm{pH}$, the flow-accelerated corrosion rate associated with morpholine is lower than with ammonia (Chexal et al. 1996).

A further increase in cold $\mathrm{pH}$ can provide additional resistance to flow-accelerated corrosion. However, the $\mathrm{pH}$ level is limited by the use of ion exchanger resins for condensate polishing. Higher $\mathrm{pH}$ levels require higher amine concentrations, which in turn requires more frequent changing of these resins, resulting in an increase in the amount of waste and in the operating costs of the ion exchangers. Therefore, different amines are being tested to find one that is effective for the entire secondary system, including both single-phase and two-phase flow regimes. One such amine is ethanolamine. The main advantage of ethanolamine, as compared to morpholine, is the lower molar concentration needed to get the desired $\mathrm{pH}$ at the operating temperature. Consequently, the load on the condensate polishers will be lower and a reduced frequency of resin regeneration will be required. Therefore, the use of ethanolamine is beneficial when condensate polishers are used. In addition, general industry experience indicates that corrosion products transport is lower with ethanolamine than that with ammonia ${ }^{1}$ and even lower than that with morpholine. A large number of plants are currently switching or contemplating switching to ethanolamine. At this time, this

I V.N. Shah, private communication with L. Goyette, Pacific Gas and Electric, Avila Beach, California, August $16,1996$. 
amine or a combination of several amines are the preferred choice for a large number of U.S. plants (Chexal et al. 1996).

The flow-accelerated corrosion rate is a function of amine type and temperature. According to the Chexal-Horowitz model, the flow-accelerated corrosion rate in single-phase flow is highest for ammonia, lowest for morpholine, and in between for ethanolamine. For example, for a $102-\mathrm{mm}$ (4-in.) diameter, 90-degree carbon steel elbow $(\mathrm{Cr}=\mathrm{Mo}=\mathrm{Cu}=0.03 \mathrm{wt} \%$ ) exposed to water having a cold $\mathrm{pH}$ of 9 and flowing at $6.1-\mathrm{m} / \mathrm{s}(20-\mathrm{ft} / \mathrm{s})$ velocity, the flow-accelerated corrosion rates are about $0.5,0.75$, and $0.88 \mathrm{~mm} / \mathrm{yr}(0.02,0.03$, and $0.035 \mathrm{in} . / \mathrm{yr}$ ), respectively, for ammonia, ethanolamine, and morpholine.
The Chexal-Horowitz model has been validated by comparing the results with available laboratory data from EDF in France and CERL in the United Kingdom and data from 20 nuclear power plants. The comparison showed that predicted flowaccelerated corrosion rates are within $\pm 50 \%$ of measured rates. This model is incorporated in the CHECWORKS, a computer code developed by the EPRI. EPRI has developed several computer codes for estimating flow-accelerated corrosion rates at power plants. All these codes are now incorporated in CHECWORKS. These codes are currently being used by all U.S. utilities. Field applications of the CHECWORKS code is discussed in Section 6.4.1. 


\section{INSERVICE INSPECTION OF PRESSURIZED WATER REACTOR FEEDWATER NOZZLES AND PIPING}

The ASME Code, Section XI, provides preservice inspection (PSI) and inservice inspection (ISI) requirements for Class 1,2 , and 3 components. As a Class 2 component, the feedwater piping inside the containment is subject to surface and volumetric examination in accordance with the Code. These examinations focus specifically on the welds and the base metal immediately adjacent to the welds and are not sufficient for detecting damage caused by flow-accelerated corrosion or thermal fatigue in the base metal away from the welds (flow-accelerated corrosion and fatigue caused by thermal stratification were not considered when the Code rules were developed). This section examines past and present ISI requirements and activities related to the feedwater system. Also, relevant and emerging technologies for examination of piping systems are discussed, and the inservice inspection experiences at non-US PWR plants are summarized.

\subsection{Inservice Inspection Requirements}

The nondestructive examination requirements during fabrication of the feedwater piping welds, the preservice and inservice inspection requirements, and the revisions to these requirements are discussed in this section. We also summarize the inservice inspections performed in response to IE Bulletin 79-13 and the inspection related activities since close-out of the bulletin.

\subsubsection{Fabrication, Preservice Inspection, and Inservice Inspection Requirements}

Current industry inspection practice relies on three levels of nondestructive examinations (NDE) to establish confidence in the piping system integrity. These levels include examinations of the welds at the time of fabrication, prior to service, and at certain intervals during service. Fabrication examinations are performed to establish the initial quality of the weld. This is followed by a PSI to establish a baseline to compare future inservice in- spection results. Finally, ISI is performed at periodic intervals to detect service-induced degradation such as cracking and corrosion in the welds and adjacent base metal.

The fabrication examinations of Class 2 piping welds are performed in accordance with the applicable construction code, that is, USAS B31.1, USAS B31.7, or ASME Section III. These examinations typically include a $100 \%$ radiographic examination.

Preservice and inservice examinations are performed in accordance with appropriate editions of the ASME Code, Section XI, specifying a volumetric examination of the inner $1 / 3$ volume of the weld and adjacent base metal for a distance of $6 \mathrm{~mm}(0.25 \mathrm{in}$.) from the edge of the weld crown, and surface examination of the outside diameter (OD) surface of the weld and $13 \mathrm{~mm}(0.5 \mathrm{in}$.) of the adjacent base metal. These requirements are applied to piping welds including those at the structural discontinuities such as vessel nozzle-topiping welds. Early editions of the ASME Code required a volumetric examination of the entire weld volume. In the Summer 1976 Addenda, the Code was revised to the current inner $1 / 3$ volumetric examination and surface examination, because it was determined that degradation initiating on the inside or outside surfaces was the primary concern, rather than imbedded fabrication defects that do not tend to propagate (Bush 1980). Appendix III of the ASME Code, Section XI, specifies the basic technique and contains calibration and examination requirements. This includes specifications for the maximum transducer element sizes and beam angles. For most pipe weld inspections, a beam angle of 45 degrees is used. Other angles are allowed if the thickness or geometry impedes the effective use of a 45-degree angle beam examination. Appendix III also requires that scanning be performed at a minimum of $6 \mathrm{~dB}$ (a factor of two) above the primary reference level established during calibration. 
ISI examinations are required at 10-year intervals, and are performed on a minimum of $7.5 \%$ of the carbon steel and low-alloy steel welds in nonexempt ${ }^{1}$ Class 2 piping, but not less than 28 welds. Welds selected for examination must be distributed among terminal ends and structural discontinuities and prorated among systems. Typically, each plant has several hundred to 1000 nonexempt, Class 2 welds; therefore, 28 to 75 welds per unit are examined. Welds examined during the initial $10-$ year interval are re-examined during successive intervals. In addition to the piping welds, the Code requires a volumetric examination of the nozzle-tovessel welds and the nozzle inside blend radii for Class 2 vessels. For multiple vessels of similar design, such as the steam generators, examinations may be limited to nozzles of one vessel or the equivalent of one vessel distributed among the vessels.

Although PSI and ISI of Class 2 components such as feedwater piping are currently required across the nuclear industry, they were not part of Section XI prior to the Winter 1972 Addenda of the 1971 Edition. Thus, when cracking was discovered in the D. C. Cook nozzles, many plants had not performed preservice or inservice examinations of the feedwater system. The lack of preservice examination data is significant as many plants did not have baseline UT data for the UT examiners to use to identify the geometric reflectors, such as the counterbore and weld root, and discriminate them from the service-induced defects. This is especially important in the case of the feedwater piping cracking, which has generally initiated at geometric discontinuities such as the counterbore corner. Also, the examination volume at plants that are performing inspections of welds in accordance with later editions of ASME Section XI, may not extend far enough to include the discontinuity at the counterbore corner. However, some utilities are including an examination of the counterbore corners in the ISI of the feedwater system. The Code of Federal Regulations, 10 CFR 50.55a,

1 Certain piping systems are exempt from examination based on size and function. With the exception of the high pressure safety injection system (HPSI), piping 4 NPS (nominal pipe size) and smaller is not subject to examination. For the HPSI, piping 1-1/2 NPS and smaller is exempt from examination.
Codes and Standards rule currently endorses by reference the inservice inspection rules in the 1989 Edition of Section XI of the ASME Code. Efforts are underway to revise this regulation.

\subsubsection{Inspections in Response to IE Bulletin 79-13}

As stated in previous sections, the cracking discovered in all eight feedwater lines at D. C. Cook Units 1 and 2 (revealed by leakage and subsequent radiographic examinations) prompted the NRC to issue a letter (USNRC 1979b) to all PWR owners, advising them of the subject of feedwater piping cracking and requesting information on the fabrication and operating history, and preservice and inservice inspections performed for the feedwater system. Later, the NRC issued IE Bulletin 79-13 (USNRC 1979a), requesting volumetric examination of the feedwater nozzle-to-piping welds at all PWR facilities with steam generators fabricated by Westinghouse and Combustion Engineering that had not received volumetric examination since May 1979. Affected licensees had 90 days to conduct the examinations. The basis of the bulletin was, "the identified degradation of these joints in the absence of a routine inservice inspection requirement." The bulletin recommended a radiographic examination, supplemented by an ultrasonic examination of all feedwater nozzle-topiping welds and adjacent base metal.' If cracking was found in these areas, additional examinations were specified for the remaining welds in the feedwater system piping up to the first piping support or snubber and at high stress points located inside the containment. In addition, the feedwater system piping supports and snubbers in containment were to be visually inspected to verify operability and conformance to design.

The bulletin also specified that all licensees with PWR facilities perform additional volumetric examinations during the next outage of sufficient duration or at the next refueling outage after the inspections mentioned in the preceding paragraph are performed. Some requirements for these additional examinations follow: for steam generator designs with common main and auxiliary feedwater nozzles, inspection of all feedwater nozzle-to-piping weld areas and all feedwater 
piping weld areas inside containment was required; also, if the auxiliary feedwater line was connected to the main feedwater line outside the containment, volumetric examination of weld areas connecting these two lines was required; and for steam generators with separate auxiliary and main feedwater nozzles, volumetric examinations of all welds inside containment and upstream of the feedwater nozzle for each steam generator were required.

As a result of these inspections, cracking was detected in 18 operating PWRs. The cracks were generally oriented circumferentially and located either at the weld root location or at the reentrant corner of the counterbore on the upstream (pipe) side of the nozzle weld, as shown in Figure 57. The cracking was determined to be caused by thermal fatigue, possibly assisted by the corrosive environment of the secondary system. As shown in the figure, cracking occurred at some plants at the counterbore corner outside the Code examination volume and, therefore, could have been overlooked during previous periodic inservice inspections. Several plants also noted pitting, which was revealed by destructive analysis. Code ultrasonic examination methods employ angle beam techniques (i.e., 45-degree shear waves) designed to detect cracks but not pits. Pit detection requires use of specialized, small-diameter, focused 0 degree probes.

\subsubsection{Activities Since Close-out of IE Bulletin 79-13}

IE Bulletin 79-13 was closed in February 1991, based on actions implemented by licensees as a result of the bulletin. As part of those actions, a number of utility ISI programs incorporated augmented volumetric examinations consisting of radiographic and/or ultrasonic examination of feedwater piping weld areas and visual examination of feedwater piping and piping supports inside containment. As a result, degradation was detected at several facilities and is listed in Appendix B of the bulletin closeout document (Foley, Dean, and Hennick 1991).

Events since the 1991 closeout of the bulletin have illustrated the potential weaknesses in ISI techniques and practices. In March of 1992, throughwall cracking was discovered in a Sequoyah Unit 1 feedwater nozzle-to-transition piece (pipe) weld. Subsequent $R T$ examinations revealed that five of the eight nozzles (at Units 1 and 2) contained significant cracking. All these welds had been previously examined ultrasonically. Further investigation by NRC inspectors revealed that the UT examinations were conducted using the minimal Code requirements and the indications had been incorrectly identified as root geometry. No supplemental or enhanced techniques were used to

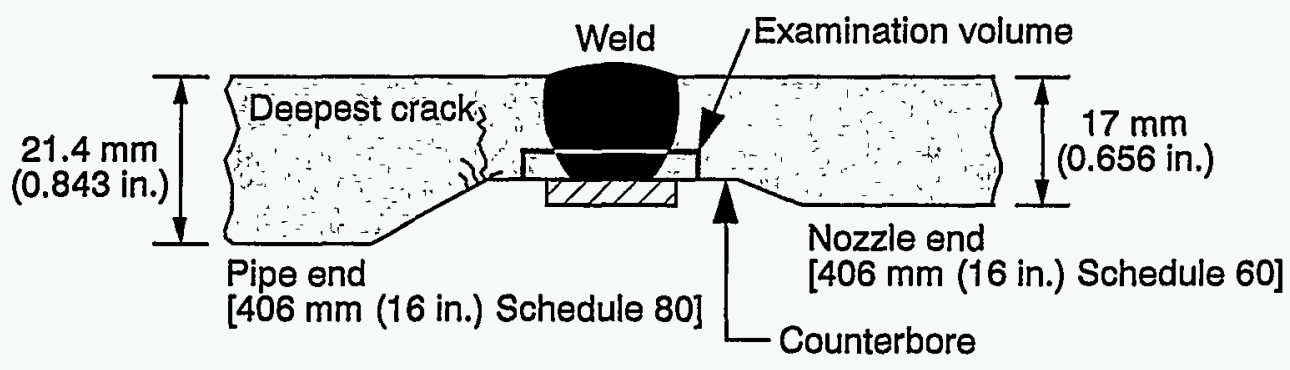

7605-WHT-795-03

Figure 57. Typical PWR feedwater nozzle-to-pipe weld with geometric discontinuity (counterbore) and cracking outside the Code examination volume.

\footnotetext{
1 A distance of at least two wall thicknesses.
} 
verify the indications. As a result of this cracking, the licensee upgraded its procedures for conducting ultrasonic examinations and expanded the examination volume for welds having the potential for being subjected to thermal stratification. The expanded volume includes the welds plus adjacent base metal for a distance of two wall thicknesses. ${ }^{1}$ In addition, the procedure requires $100 \%$ examination of the steam generator nozzle transition piece. The licensee has also incorporated into their procedures a number of enhanced ultrasonic techniques to aid in the evaluation of detected indications.

Another incident involving misinterpretation of crack indications occurred at Diablo Canyon, Unit 1. These cracks were oversized by ultrasonic examination, which resulted in removal of the affected weld. Subsequent metallurgical results indicated that the UT had oversized the $0.86-\mathrm{mm}$ (0.034-in.) deep crack by a factor of ten owing to inclusions in the weld area (PG\&E 1992). These same cracks were not detectable with $\mathrm{RT}$. In a follow-up meeting with the $\mathrm{NRC}$, the licensee concluded that Code examinations were not adequate for small thermal fatigue cracks and enhanced ultrasonic techniques, including automated scanning, were necessary to improve reliability, accuracy, and repeatability (Peterson 1992).

The concept of using enhanced UT techniques for thermal fatigue is not new. As a result of throughwall cracking in stainless steel piping, caused by thermal stratification, the NRC recommended in NRC Bulletin No. 88-08, Supplement 2, the use of enhanced UT techniques and procedures, and stated that UT procedures that qualified for the detection of IGSCC in BWR recirculation piping have demonstrated effectiveness for detecting thermal fatigue cracks (USNRC 1988d). Although the use of IGSCC-qualified techniques can provide improvement over basic Code-prescribed techniques, these enhanced techniques may not be effective "as is." As stated in Section 6.3.1.2 of

\footnotetext{
1 The extended examination of the adjacent base metal may not include the reentrant corner of the counterbore at some PWRs.
}

this report, a through-wall crack at Sequoyah Unit 1 was not detected during UT examinations using IGSCC-qualified techniques and procedures. Unoptimized IGSCC-qualified techniques and the inspectors' lack of experience with thermal fatigue cracks were cited as the cause.

Some optimization of the IGSCC-qualified techniques is necessary to accommodate material differences and to ensure reliable detection of cracking outside the heat-affected zone. First, carbon steel components exhibit less attenuation to ultrasound than stainless steel components. Thus, higher frequencies which provide greater sensitivity for detecting small defects, can be used for carbon steel. Second, an optimum scanning sensitivity can be established for thermal fatigue cracks in carbon steel to provide more reliable examination procedures. As mentioned, the Code requires a scanning sensitivity of at least $6 \mathrm{~dB}$ above the primary reference level. For IGSCC, industry practice is to use additional instrument gain. Such scanning is performed with the material grain noise amplitude set at 5 to $10 \%$ (EPRI 1983). This approach was intended to maximize the low amplitude responses from the IGSCC. Third, since cracking often occurs at geometric discontinuities outside the heat-affected zone, inspectors can be trained to look for and expect cracking in areas away from the weld. Several licensees are now using enhanced inspection techniques, such as tip-diffraction and creeping wave techniques, and providing training to their inspectors using the removed portions of the damaged feedwater piping.

\subsection{Advancements for Inservice Inspection of Fatigue Cracks}

The different inservice inspection techniques for detection and sizing thermal fatigue cracks in feedwater piping are discussed in this section. We also discuss the selection of the inservice inspection locations critical to plant safety or with high failure probabilities. 


\subsubsection{Emerging Inservice Inspection Methods}

Nuclear plant operators have the choice of two volumetric examination methods, $\mathrm{RT}$ and $\mathrm{UT}$, for the detection of cracks which initiate on the pipe inside surfaces in a weld or adjacent base metal. Each method has advantages and disadvantages, but the information provided by each method can complement the information provided by the other method. In particular, radiography can provide reliable information about the geometric characteristics of the inside surface, and enhanced ultrasonic examinations can provide reliable detection and sizing of fatigue cracks.

The inherent advantage of radiography is that the testing can be performed through the insulation and a permanent record is obtained, which can be compared with future examinations. The resulting image can also be used to characterize the weld geometry. Many disadvantages stem from convenience factors, including: radiological controls that may interfere with critical path activities, interference from contaminated and irradiated components, and access to the inside surface (which is available only at plants with gamma plugs installed in the pipe wall adjacent to the feedwater nozzle, otherwise, double wall techniques with reduced sensitivity must be used). The final consideration is that $R T$ is arguably a less sensitive method for crack detection compared to other NDE methods and is generally not capable of determining the through-wall extent of the cracks. Although RT is sensitive to defects that are volumetric in nature (e.g., wall thinning, slag inclusions, etc.), the density difference caused by a tight crack may be insufficient for detection if the orientation of the crack is not parallel to the gamma or $\mathrm{x}$-ray. However, the fatigue cracks in the feedwater piping are often open and filled with oxides and can be detected with radiography.

UT is the primary volumetric method used for inservice inspection, and, in accordance with ASME Section XI Code (1989), flaw detection is achieved by comparing the signal amplitude of a flaw indication to that of a known reflector, such as a notch or a hole in a calibration block. The responses from known calibration reflectors are used to construct a distance-amplitude correction (DAC) curve used to compensate for the attenuating effects of the material. This DAC curve is considered the primary reference level. Reflectors that produce a response greater than the specified percent of DAC are investigated and recorded. In the 1986 Edition of Section XI, this recording level was lowered from $50 \%$ to the current $20 \%$ DAC, largely due to the work performed in the Program for Inspection of Steel Components (PISC) project that indicated that the $50 \%$ recording level was unreliable and that recording levels lower than $20 \%$ DAC produced an excessive number of false calls (PISC-II 1985). In addition, a requirement was added to record any indication of a suspected flaw regardless of amplitude. In accordance with the Code, the endpoints or length of the flaw indication are estimated by moving the ultrasonic transducer parallel to the reflector until the signal amplitude is reduced to $50 \%$ of the maximum signal amplitude. As will be discussed later, a similar amplitudebased approach was used in the past to determine the through-wall extent of the flaw indication, but has been abandoned for more reliable techniques.

The conventional amplitude-based UT techniques can detect fatigue cracks in ferritic steel piping but have a very poor sizing capability for these cracks. This is illustrated by the round robin UT inspections of thermal fatigue cracks in LWR primary coolant piping conducted in 1981 using the 1977 Edition of the ASME Code, Section XI. The results for crack detection reliability are shown in Figure 58 and those for crack sizing accuracy shown in Figure 59 (Muscara 1990). The inspection results presented in Figure 58 show that conventional UT can reliably detect thermal fatigue cracks in clad ferritic steel piping whereas it usually can not detect such cracks in centrifugally cast stainless steel piping. This figure also shows that conventional UT can not detect IGSCC cracks in wrought stainless steel piping as reliably as thermal fatigue cracks in clad ferritic steel piping. For example, the probability of detecting a $20 \%$ through-wall crack was about $80 \%$ for clad ferritic steel, $55 \%$ for $250-\mathrm{mm}$ (10-in.) wrought austenitic steel, and $20 \%$ for cast austenitic piping. 
INSERVICE INSPECTION

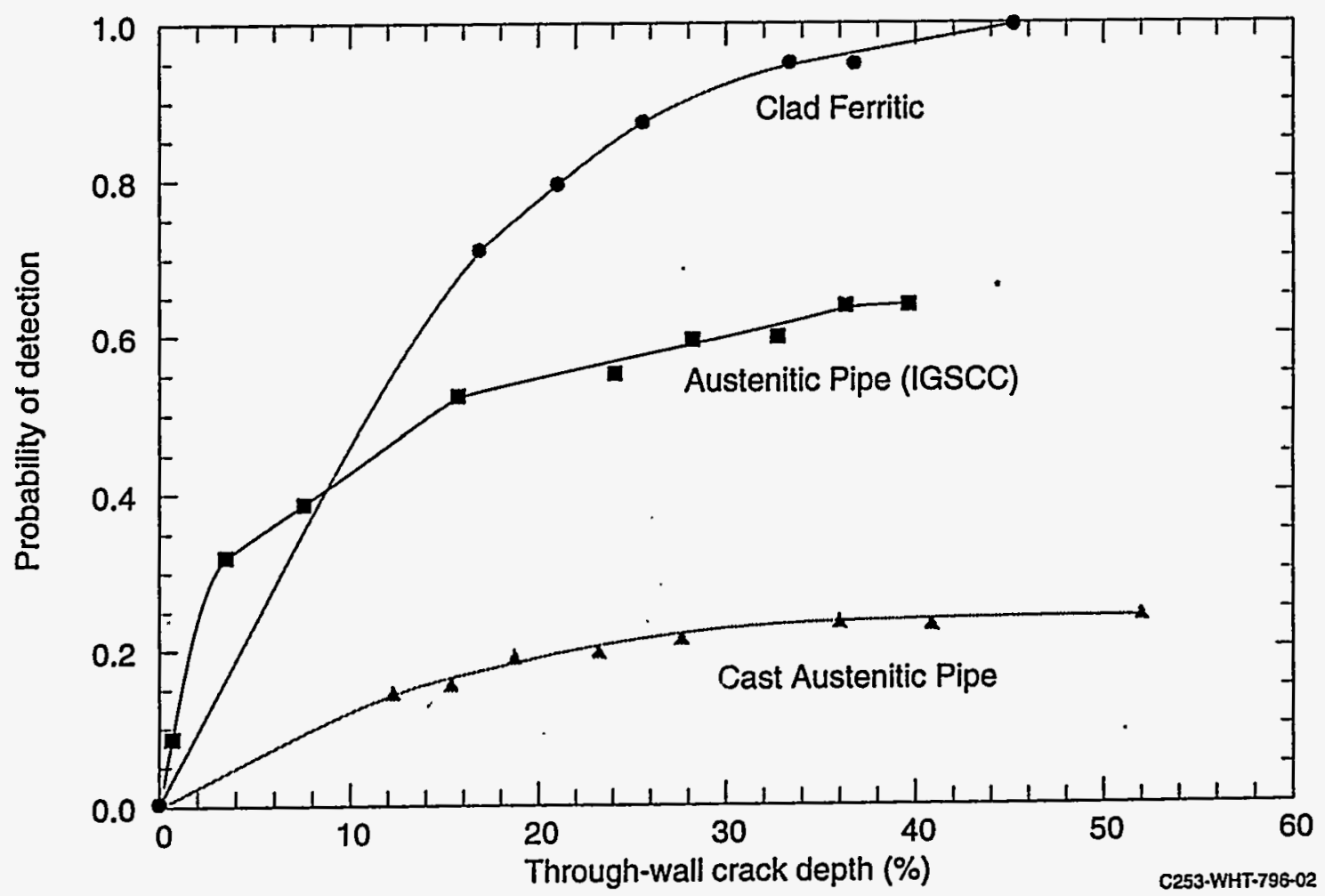

Figure 58. Probability of detection versus depth of thermal fatigue cracks in clad ferritic and cast austenitic pipe and of IGSCC cracks in wrought austenitic pipe - piping inspection round robin results (Muscara 1990). Copyright ASM International; reprinted with permission.

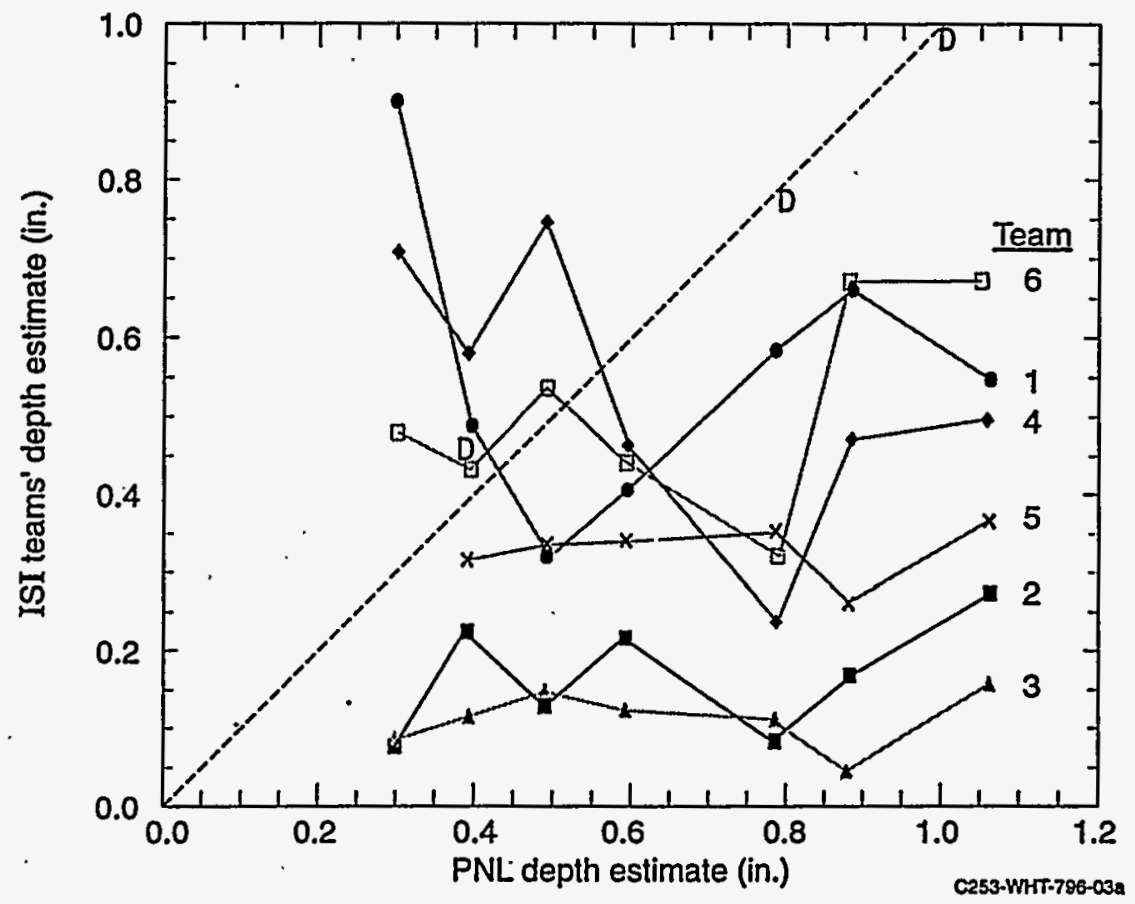

Figure 59. Depth of thermal fatigue cracks in clad ferritic material as estimated by the six inservice inspection teams with the conventional UT techniques versus that estimated by Pacific Northwest Laboratory with the enhanced UT techniques. Three destructive analysis results (D) are also plotted (Muscara 1990). Copyright ASM International; reprinted with permission. $(1 \mathrm{in} .=25.4 \mathrm{~mm})$ 
However, it is difficult to accurately size thermal fatigue cracks in ferritic steel piping using conventional UT techniques as shown in Figure 59 (Muscara 1990, Doctor 1984). The figure shows a comparison between the crack depths estimated by the six ISI teams using the conventional UT techniques and those estimated by the Pacific Northwest Laboratory (PNL) staff using enhanced UT techniques such as tip diffraction techniques. Figure 59 also shows that the PNL crack depth estimates compare well with three destructive evaluation results. Accurate crack sizing is needed for evaluation of the structural integrity of flawed piping. The national and international studies coordinated by the Pressure Vessel Research Committee and the PISC, respectively, have also revealed the poor capability of conventional UT for sizing of flaws in pressure vessels and nozzles. These studies indicate that there are large variabilities between different UT procedures.

Although UT is capable of detecting many types, sizes, and orientations of cracking, manual UT examinations have two inherent disadvantages: reliance on the inspectors' ability and judgement, and the lack of a permanent record. For the feedwater piping, these problems resulted in inconsistent results, miscalls of both cracks and weld geometry (often owing to the lack of baseline data), and a general lack of confidence in IIT. Because of these inconsistencies and miscalls, the limitations of the Code-prescribed techniques are well recognized. These failures illustrate the need to move beyond the minimum requirements of the Code to provide a more reliable examination, driving industry to develop enhanced inspection techniques.

Inservice inspections of IGSCC in BWR primary piping have also revealed some of the shortcomings of the conventional ultrasonic examination methods. The inability of ultrasonic inspection methods to detect IGSCC in the thickwall, largediameter, stainless steel recirculation piping at the Nine Mile Point Unit 1 resulted in the USNRC requiring specific performance capability demonstrations for this inspection technique (USNRC 1982,1983 a). In response to this need, the ASME Section XI Subcommittee on Inservice Inspection developed Appendix VIII, which is discussed later in this section. Several enhanced inspection techniques have been developed for reliable detection and sizing of IGSCC.

Knowledge gained from inspecting for IGSCC has provided improvements in three areas that apply to all examinations of piping welds. These areas are: (1) improved search units employing a variety of angles, modes, and configurations; (2) proactive procedures relying on numerous techniques to verify and discriminate inservice degradation from weld geometry; and (3) the use of automated inspection equipment to improve reliability and repeatability, and to provide a permanent record of the examination. Carbon steel is less attenuative acoustically than stainless steel; therefore, the same angles, modes, and configurations can be used to search for thermal fatigue cracks in carbon steel, with small adjustments in frequency to optimize for the material differences.

Improvements in search unit technology have moved far beyond the 45-degree shear wave approach prescribed by the Code. Manufacturers now build numerous types of search units with different wave modes (shear, longitudinal, and multimodes), angles, and configurations (single, dual element, tandem, phased arrays), designed to enhance the sensitivity of their equipment to cracks. Supplementing the Code techniques with these enhanced inspection techniques and using a proactive approach to examining components is far more effective than use of the Code requirements alone.

Another improvement to consider is the use of automated inspection equipment to collect and store ultrasonic data. Automated scanning of the feedwater nozzles was performed at San Onofre Unit 3 using the Introspect/98 volumetric inspection system (Mostafa and Ramsey 1994). Using computer processing, a 3-dimensional evaluation of the data was performed to enhance the ability of an analyst to characterize flaws and discriminate geometrical reflectors on the inside surface. Such enhanced evaluations are becoming routine and are possible with many modern-day scanning systems. 
Creeping Wave and Related Mode Conversion Techniques. An approach developed for IGSCC inspection that can be effective for the inspection of feedwater piping with thermal fatigue is the use of ID creeping wave and related mode conversion techniques to detect and qualitatively size the fatigue cracks. This family of techniques has gained wide acceptance in the nuclear industry because of its high sensitivity to ID connected flaws. The ID creeping wave is generated as a result of a high-angle refracted longitudinal wave. When an angle of incident, $\alpha$, for a longitudinal wave is slightly less than the first critical angle, $\alpha_{c r}$ four modes of ultrasonic waves are generated below the front surface (see Figure 60): shear wave $S$ at the refracted angle $\beta_{s}$, longitudinal wave $L$ at the refracted angle $\beta_{1}$, creeping wave $C_{f}$ along the front surface (also called an OD creeping wave), and an indirect shear wave, $S_{i}$, radiating from the creeping wave $C_{f}$ (Brook 1986, Davis 1991). Mode conversion takes place at the back surface because it is parallel to the front surface, and the indirect longitudinal wave, $\mathrm{L}_{\mathrm{i}}$, along with the shear wave, $\mathrm{S}$, are reflected from the back surface. In addition, the indirect shear wave mode converts at the back surface to produce a back surface creeping wave, $\mathrm{C}_{b}$, which is also called an ID creeping wave (Brook 1986). Creeping waves can be used to detect very shallow OD or ID defects, as shown in Figure 61(a) and (b) respectively, provided that the OD and ID surfaces are parallel.

In addition to the creeping wave, the multiple modes and high angle longitudinal wave make it possible to characterize and size cracks with the same search unit, as shown in Figure 61(c) (Brook 1986, Davis 1991). An indirect longitudinal wave $\left(L_{i}\right)$ is generated at the ID surface, which, if reflected off the crack face, returns to the transducer as a longitudinal wave. However, a shallow crack would not cause reflection of the indirect longitudinal wave. Thus, the indirect longitudinal wave can indicate the presence of deeper ID cracks (for example, deeper than $25 \%$ through-wall), which may be confirmed by the presence of a tip-diffracted signal from the direct $L$ wave, as shown in Figure 61(d). Using this multimode approach, the presence or absence of certain signals (i.e., $C_{f}, C_{b}$,
$\mathrm{L}_{\mathrm{i}}$ and $\mathrm{L}$ ) as a qualitative sizing tool, can provide inspectors with additional confidence when evaluating crack indications and help avoid miscalls. For example, as described in a previous section, shallow cracks detected at Diablo Canyon, Unit 1, were oversized owing to the presence of inclusions that were mistaken for the crack tip. Use of the multimode evaluation approach can help avoid this type of interpretation by allowing the inspectors to confirm the crack depth in a qualitative, but reliable, manner. The disadvantages of this approach are the complexity of signal interpretation and potential interference from nonparallel ID and OD component surfaces that may cause redirection of the reflected and mode converted waves.

Tip-Diffraction Techniques. A widely used method for crack depth sizing is the use of a diffracted wave from the crack tip. Techniques that use the tip-diffracted signal are generally known as tip-diffraction techniques. These techniques measure the time-of-flight to the crack tip to estimate the crack depth. As a result of the impinging sound beam, a diffracted wave is produced from the crack tip that radiates like a point source in all directions. Thus, the diffracted wave can be detected as it scatters backward or forward. An example of a backscatter technique is shown in Figure 61(d), using the direct L-wave from the creeping wave probe. The sound beam is transmitted and received from the same side of the crack. Other examples of backscatter tip diffraction techniques are the Satellite Pulse Observation Technique (SPOT), which measures the difference in time-of-flight between the tip and a corner signal, and PATT (pulse arrival time techniques) which measures the direct time to the tip signal.

An example of a forward scattering tip-diffraction technique is the time-of-flight diffraction (TOFD) method (Pers-Anderson 1993). This is a crack-tip diffraction method that employs opposing elements, as shown in Figure 62(a). Two signals are present in the absence of a crack: a direct lateral wave signal and a back wall reflection signal from the ID surface. Diffraction occurs when the in coming sound beam impinges upon a finite planar reflector such as a crack. The diffracted sound energy from the crack tip acts as a point source and 


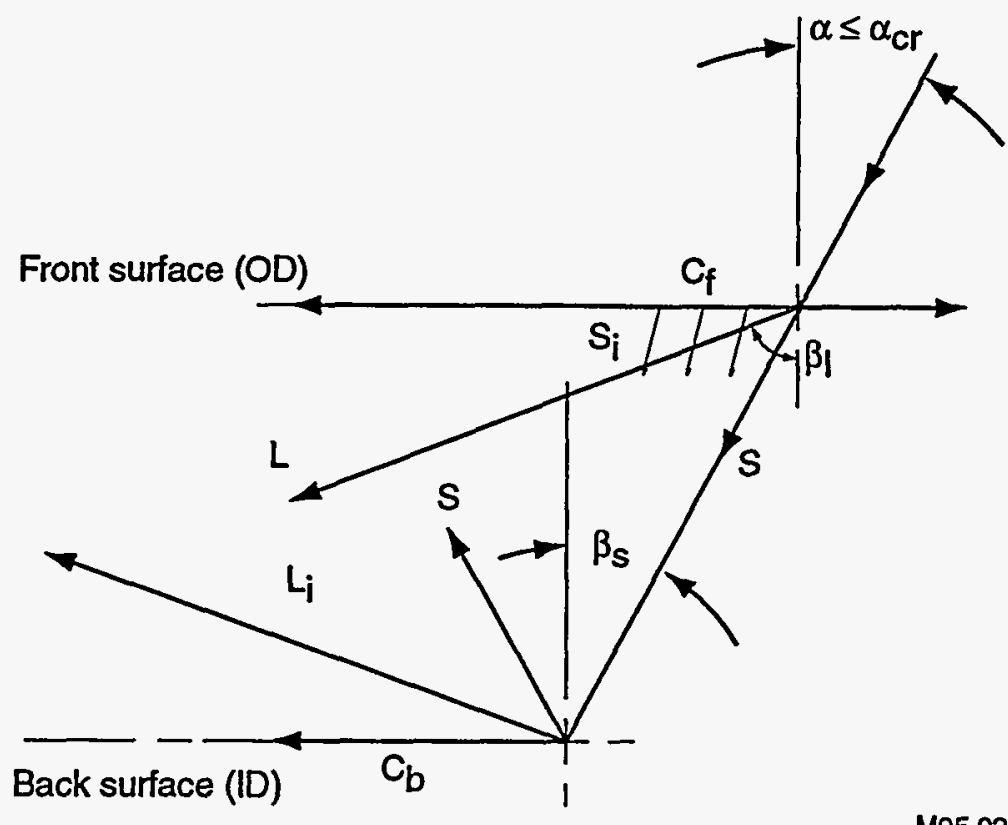

M95 0217

$\begin{array}{ll}C_{f} & \text { Front surface creeping wave } \\ C_{b} & \text { Back surface creeping wave } \\ L_{1} & \text { Direct longitudinal wave } \\ L_{i} & \text { Indirect longitudinal wave } \\ S & \text { Shear wave } \\ S_{i} & \text { Indirect shear wave } \\ \alpha & \text { Incident angle } \\ \alpha_{C r} & \text { Critical incident angle } \\ \beta_{I} & \text { Refraction angle for longitudinal wave, } L \\ \beta_{S} & \text { Incident angle at back surface }\end{array}$

Figure 60. Scheme of ultrasonic fields of creeping wave probe in test specimen depicting front and back surface creeping waves, direct and indirect longitudinal waves, and direct and indirect shear waves (Brook 1986). Copyright ASM International; reprinted with permission. 
(a) Detection of $\mathrm{OD}$ crack using front surface creeping wave $\left(C_{f}\right)$

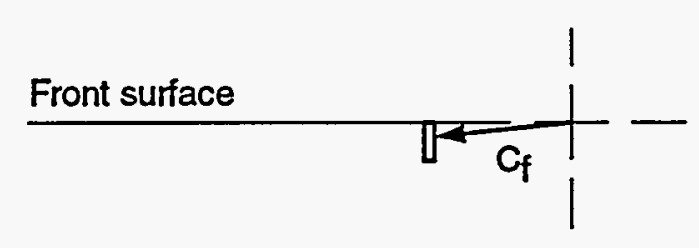

(b) Detection of ID crack using back surface creeping wave $\left(C_{b}\right)$

(c) Crack depth classification using indirect longitudinal wave $\left(L_{i}\right)$

\section{Back surface}
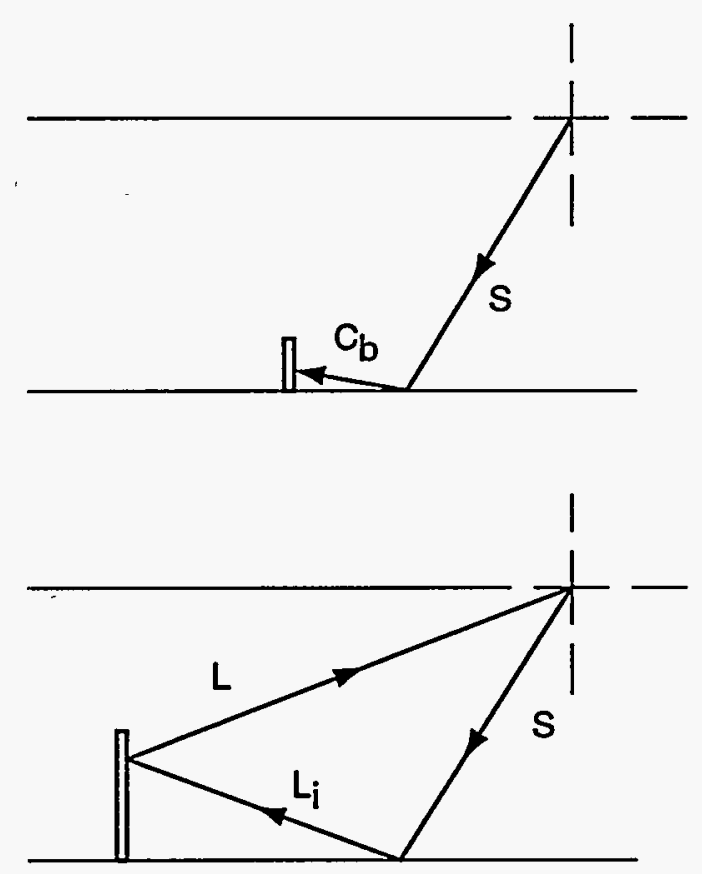

(d) Crack sizing using tip-diffracted direct longitudinal wave $(L)$

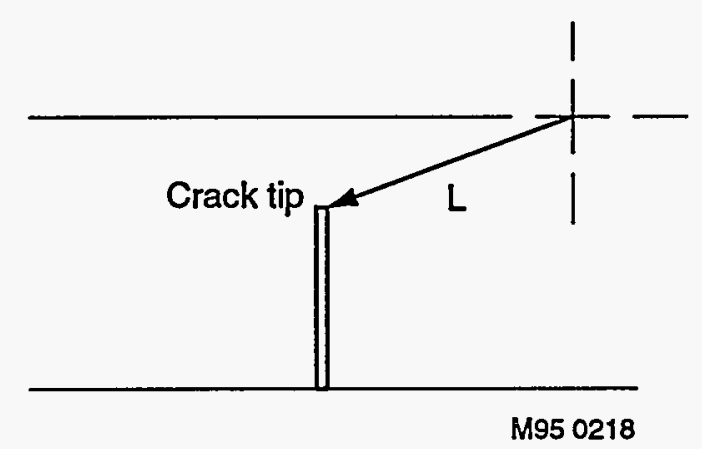

Figure 61. Potential beam propagation paths for multimode approach using creeping wave probe (Brook 1986). Copyright ASM International; reprinted with permission. 
(a)

No crack

(b)

Inside-diameter crack

(c)

Through-wall crack

(d)

Embedded crack
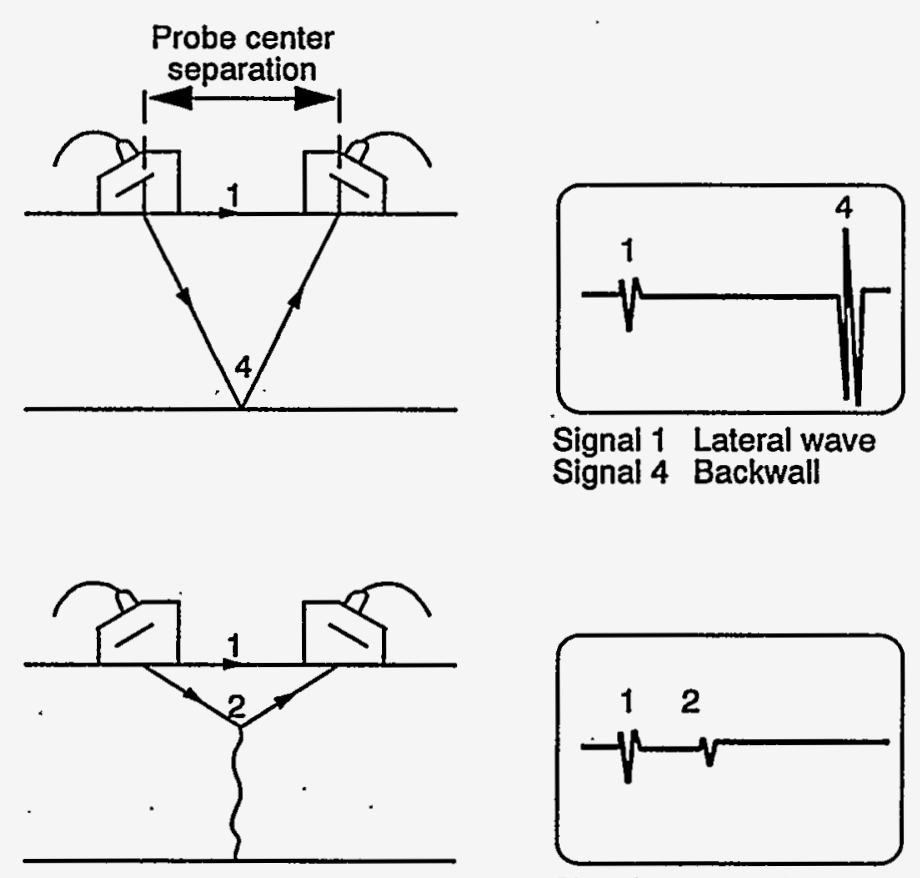

Signal 1 Lateral wave Signal 2 Upper crack tip

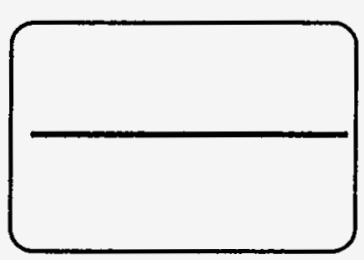

No signal
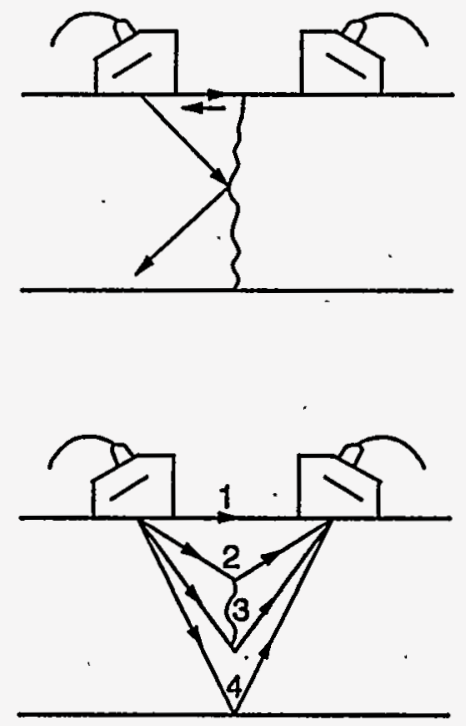

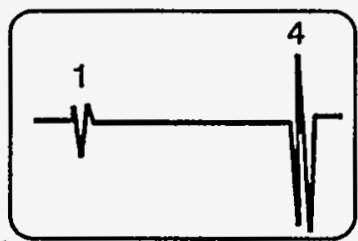

Signal 1 Lateral wave Signal 4 Backwall

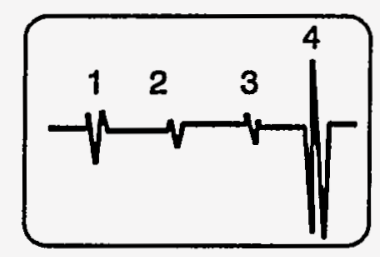

Signal 1 Lateral wave Signal 2 Upper crack tip Signal 3 Lower crack tip Signal 4 Backwall

2605-WHT-785-0ta

Figure 62. Examples of time-of-flight (TOFD) diffraction signals (Pers-Anderson 1993). Copyright TRC; reprinted with permission. 
radiates a sound wave to the receiving transducer. The time of arrival of this signal can then be used to pinpoint the tip of the crack and determine crack depth. Figure 62(b) illustrates such a diffracted signal produced by the tip of an insidediameter crack; note the absence of a back wall reflection signal and the presence of a lateral wave signal. As shown in Figure 62(c), a through-wall crack would of course eliminate all signals, and all signals would be present for an embedded crack, as shown in Figure 62(d). This approach provides a means of both sizing and verifying the extent of the crack, but can be hindered by weld geometry on the OD and ID surface which can cause a loss of surface contact and/or the loss of back wall and lateral wave signals for reasons other than the presence of a crack.

The improvement in sizing technology using the time-of-flight techniques is demonstrated by the data from the PISC II trials, which, as discussed above, showed that amplitude-based methods were unreliable for determining the through-wall extent of a crack (Cowfer 1989). Since that time, numerous transducer configurations (e.g., tandem, dual, multimode) have been developed to optimize the response from the crack tip and other portions of the crack (i.e., the tip, face, and base) to aid in crack sizing. Back scattering and time-of-flightdiffraction techniques are just two approaches to tip-diffraction techniques developed in recent years.

The tip-diffraction techniques and other UT techniques can overestimate the through-wall extent of a crack in carbon steel feedwater piping if inclusions such as $\mathrm{MnS}$ are present near the plane of a crack. For example, a tip-diffraction technique overestimated the depth of crack in the carbon steel feedwater piping at the Diablo Canyon Unit 1 because of inclusions present near the crack tip. ${ }^{1}$ Therefore, discrimination of reflectors (for example, inclusion, geometry effect, and crack tip) and use of more than one inspection technique for confirming the inspection results is advised. Also,

1 V. N. Shah, Private conversation with Dave Gonzalez, Pacific Gas and Electric, June 19, 1996. use of an imaging technique such as SAFT-UT can provide accurate sizing of a crack.

Phased Array Technique. Ultrasonic examination methods based on the phased array technique have been developed for inservice inspection of components such as feedwater nozzles which have a complex geometry, and have a very limited access and clearance. One such technique developed by Siemens has been used for inspection of the BWR feedwater nozzle inner radius region, nozzle bore, and nozzle to vessel weld; the BWR bottom head ligaments; and the PWR closure head ligaments (Rathgeb et al. 1992). This technique has also been used to inspect the inner radius regions of PWR feedwater nozzles.

A phased array transducer consists of multiple elements that can be controlled individually to create a variety of beam patterns. The use of multiple elements with a computer controlled pulsing sequence results in the ability to steer and/or focus the sound beam, as shown in Figure 63 (Bray and Stanley 1989). With an appropriate phase-shifting of the transducer elements, the focal length of the transducer can be changed and the specimen can be scanned in depth. The transducer design can be tailored to the needs of the specific examination. For example, the examination of a nozzle inner radius region employs a fixed incident angle with a variable skew angle whereas the vessel shell welds require a fixed skew angle with a variable incident angle.

Data collected during the inspection are digitized and then stored on removable computer hard disks. These data are analyzed using a personal computer program. The program provides several different displays to facilitate accurate analysis of reflectors: A-scan, B-scan, C-scan, and UT Echo Tomography, which requires that the echoes received in many cross-sectional directions are stored during inspection. The echo tomograph utilizes the spatial relationships of the signals in order to enhance the signal to noise ratio. The combination of these display modes allows a rapid and accurate analysis of the reflectors. Flaw sizing is typically done with a tip diffraction method (Fischer et al. 1992). 


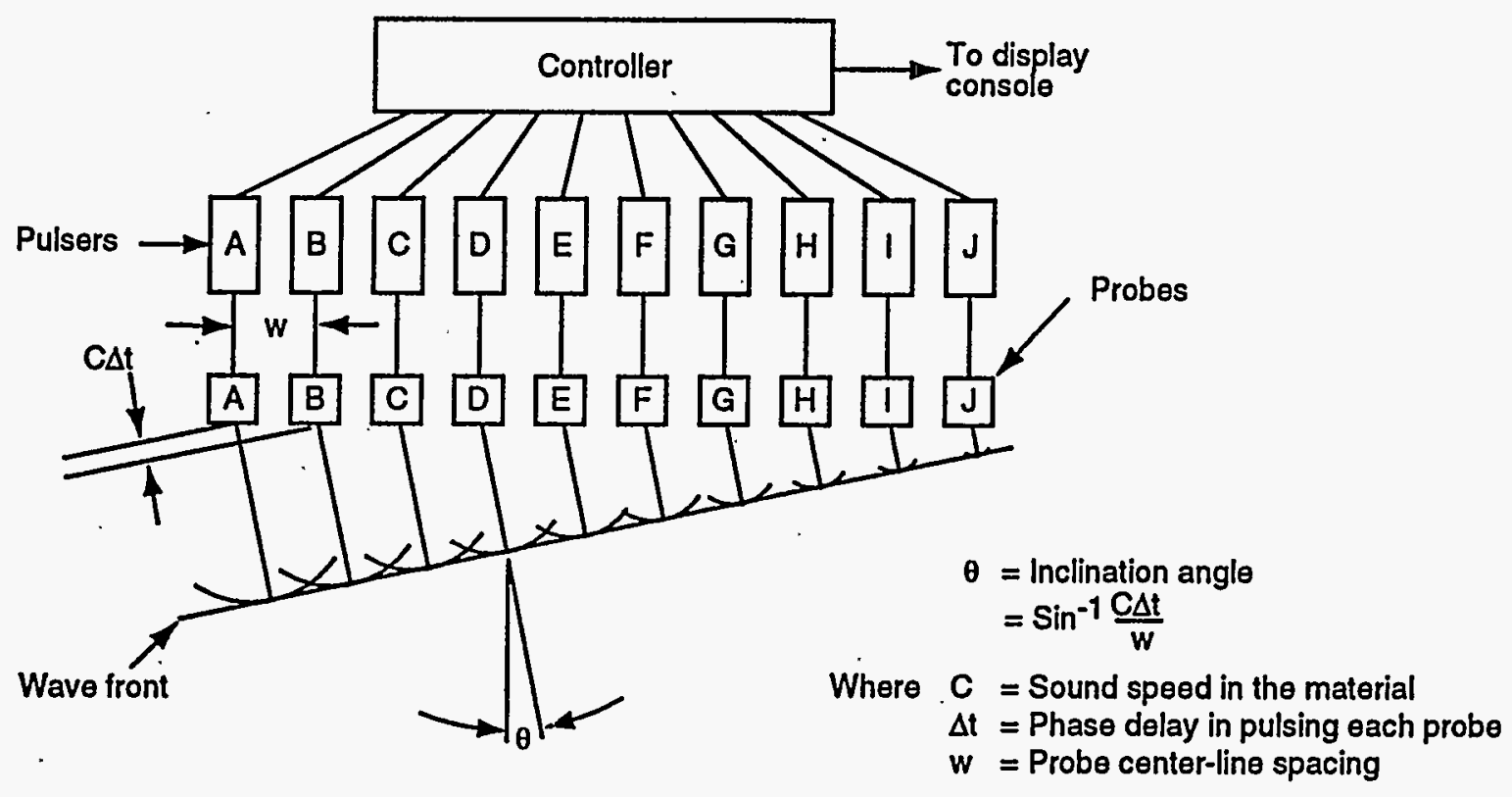

M96 0337

Figure 63. Typical phased-array transducer(Bray and Stanley 1989). Copyright McGraw-Hill; reprinted with permission.

Another example of the application of the phased array technique is the TestPro/FATS system (Bisbee 1994). FATS (Focused Array Transducer System) is a phased array technique, which allows the beam to be focused electronically to the area of interest. This method reduces beam spread and allows the beam to focus on the crack opening to enhance detection, or focus on the crack-tip to improve sizing accuracy. The focused array transducer system, combined with the TestPro ultrasonic acquisition system, results in a complete system for acquisition, analysis, imaging of ultrasonic data, and interfacing with scanning devices.

Computed Tomography. One of the problems with performing UT examinations on piping welds is discriminating the weld geometry from the cracks. Therefore, an accurate representation of the weld geometry is important. Owing to variation in weld geometry from weld to weld and to the inaccuracies of as-built drawings, weld profiles of each weld examined are a necessity. One method of obtaining this is by plotting thicknesses obtained by ultrasonic measurements. An alternate method used in Japan to visualize the weld geometry is the use of computed tomography (CT) imaging of radiographic data (Maeda and Yagawa 1991). The advantage of this approach is that an accurate cross section of any section of the weld, including the reentrant corner of the counterbore, can be obtained. The disadvantage is the expense and time required for performing such an examination.

Synthetic-Aperture Focusing Technique for UItrasonic Testing (SAFT-UT). SAFT-UT is an effective technique for characterizing flaw size, shape and orientation. This technique uses reflected ultrasonic waves to form a high quality image of a detected discontinuity that can be easily interpreted. The ultrasonic pulses 
returned from a test sample contain much more useful information (both amplitude and phase information) about the interaction between the ultrasound and the material than is commonly extracted from conventional ultrasonic displays. The image formed by SAFT-UT contains this information, which can be used to characterize many material discontinuities including thermal fatigue cracks.

The SAFT-UT method is based on the concept of collecting data from scanning with a small, highly divergent (unfocused) transducer element. The use of a large divergence is based on the idea that the more often a given discontinuity is seen by a transducer, the more information can be gathered about the discontinuity, and more precisely the discontinuity can be characterized. The first step in synthetic-aperture data processing is to choose a set of transducer element positions to be processed as a unit. The data are then processed electronically by introducing appropriate time shifts into the inspection data from each position, so as to simulate a larger transducer with much better resolution and signal-to-noise ratio. The electronic processing of the data results in focusing of the collected data. Thus the processing of the data in effect synthesizes the physical processes occurring in a large, but unobtainable, transducer (aperture). Therefore, this method is referred to as the synthetic-aperture focusing technique (Seydel 1982).

Three different tests have been performed since 1989 to validate SAFT-UT: (1) participation in the Miniature Round Robin conducted at the Pacific Northwest Laboratory, (2) tests at the EPRI NDE Center, and (3) tests conducted as part of the Programme for the Inspection of Steel Components, Phase 3 (PISC-III). The participation in the Miniature Round Robin was limited to an evaluation of the detection capability of SAFT-UT; no evaluation of its sizing capability was performed. For small cracks, average length of $7.4 \mathrm{~mm}$ (0.29 in.) and depth of $1.1 \mathrm{~mm}$ (0.043 in.), which is equivalent to $4 \%$ through wall, the probability of detection and false call probability were, respectively, $67 \%$ and $14 \%$. The corresponding values for large cracks, average length of $187.7 \mathrm{~mm}$ (7.4 in.) and depth in the range of 4.3 to $11.2 \mathrm{~mm}$
( 0.17 to 0.44 in.), were $95 \%$ and $18 \%$. SAFT team performance was better than the average of the manual or automated inspection teams participating in the Miniature Round Robin.

The blind tests conducted at the EPRINDE Center were for evaluation of SAFT-UT's capabilities for IGSCC detection and sizing. SAFT-UT detected seven out of 10 defects. The detection tests identified several weaknesses of the system and where improvements were needed. These improvements have been made. The sizing tests indicated that SAFT-UT has a tendency to undersize the deeper cracks.

Inspection of the PISC-III full scale reactor pressure vessel was selected as a blind test for evaluating SAFT-UT. The test involved characterization of twelve defects in the vessel. The SAFT-UT system was used to size 8 of the 12 defects. There was a reasonable agreement for the size of six of the eight defects. The comparison of the SAFTUT system with the other inspection systems will be made after the detailed analysis of the inspection results, which is currently in progress, is completed. The SAFT technology has been integrated into the ASME Code Section V, Article 4, Appendix E, which addresses computerized UT imaging systems, which also includes UT-phased arrays (Doctor et al. 1995).

Field application of the SAFT technology has included an inspection of a plate in the PISC II program, detection and sizing of IGSCC in the BWR recirculation piping at Dresden Unit 3 and Vermont Yankee, characterization of an indication in Indian Point 2 reactor pressure vessel, and a special ultrasonic examination of a statically cast stainless steel hot-leg elbow at Trojan. The SAFT analysis of the inspection data for the Indian Point 2 reactor pressure vessel showed that the defect was volumetric and was not connected to the surface. The application at Trojan showed that SAFT can be successfully coupled with commercial UT equipment and scanner systems in an onor off-line mode. This application also showed that the SAFT results are easy to understand and provide images that others can readily interpret (Doctor et al. 1995). 


\subsubsection{UT Performance Demonstration}

Nondestruictive examinations are now recognized as an essential element in the safe operation of nuclear power plants. They can be used for demonstrating that defects of a size sufficient to threaten the structural integrity of the plant are absent both prior to operation and at intervals during service. However, a number of events, such as inspection of the thermal fatigue cracks in the ferritic steel feedwater piping and the IGSCC in the wrought stainless steel piping during the 1970 s and $80 \mathrm{~s}$, have diminished confidence in the ability of the nondestructive methods to fulfil this role. These events have prompted the regulatory and Code bodies to adopt different approaches. In the past, the ASME Code used prescriptive standards for the nondestructive examinations. These standards described in detail how the nondestructive examination was to be performed. However, these prescriptive standards had several disadvantages. In particular, it was very difficult to introduce any improvements in these standards and they inhibited the introduction of new nondestructive examination methods. The ASME Code has addressed this problem by replacing the prescriptive standards with performance requirements. This change in the Code approach to inservice inspection leaves the responsibility for the nature and detail of the inspection entirely with the plant owner who is free to use whatever inspection method is judged to be appropriate. However, there must then be a demonstration that the method chosen is capable of meeting the requirements placed on it by the Code.

The 1989 edition of ASME Section XI (ASME 1989a) includes a mandatory Appendix VIII, Performance Demonstrations for Ultrasonic Examination Systems, which provides requirements for the performance demonstration of the ultrasonic examination personnel, procedures, and equipment used to detect and size flaws. The intent of Appendix VIII is to establish a minimum level of skill and effectiveness for ultrasonic inspection systems. It will be a requirement for the inservice inspection of both austenitic and ferritic piping welds, vessels, vessel nozzles including the nozzle inside radius sections, and bolts and studs. Although the implementation schedule is still uncertain, the U.S. industry is in the process of preparing the necessary test blocks for the performance demonstrations (Spanner et al. 1992, Becker et al. 1992). In order to minimize the number of samples needed and eliminate the need for site-specific qualifications, test blocks are being prepared to cover a range of pipe sizes and thicknesses rather than one block for each specific size. Performance demonstrations are to be carried out on test blocks with weld preparation, geometry, and access conditions representing those encountered during inservice inspection. The geometric conditions include those that normally require discrimination from flaws. One example of such a geometric condition is a counterbore at the feedwater nozzle. The test blocks must also contain a certain number of realistic defects to confirm inspection technique reliability. For ferritic piping welds, at least $75 \%$ of the defects must be either mechanical or thermal fatigue cracks.

Acceptance criteria for detection and sizing of flaws in the test specimens are provided in Appendix VIII. The detection specimens include both flawed and unflawed test specimens. A minimum of $1 / 3$ of the flaws are required to have depths between $5 \%$ and $30 \%$ of the nominal pipe thickness. At least $1 / 3$ of the flaws are required to have depths greater than $30 \%$ of the nominal pipe wall thickness. There are also requirements about the orientation of these flaws in the test specimens. At least one and a maximum of $10 \%$ of the flaws must be oriented axially. The remainder of the flaws must be oriented circumferentially. Serviceinduced flaws shall be included when available. For sizing samples, a minimum of $20 \%$ of the flaws in each of the following three groups of flaw depths is required: 5 to $30 \%, 31$ to $60 \%$, and 61 to $100 \%$ of the wall thickness.

The costs associated with compliance to Appendix VIII are high, especially for the feedwater nozzle inside radius section, because it requires a large number of mockups. Use of computer modeling of the ultrasonic examination process can result in a reduction of the resources needed to comply with Appendix VIII. By modeling the change in ultrasonic beam angle with changing test part geometry, the number of specimens required for 
performance demonstrations can be reduced. Computer modeling can also help in determining the best position and angle for a given probe for inspecting a crack of given size and orientation, located in the nozzle inside radius section. ASME Section XI Code Case N-552 Alternative Methods - Qualification for Nozzle Inside Radius Section from Outside Surface permits such modeling to reduce the number of specimens for demonstration of the ultrasonic systems used for nozzle examinations. ${ }^{1}$ A non-mandatory Appendix to Section XI of the ASME Code, covering validation of computer models is in the Code-approval process.

Silk (1996) discusses the use of computer processing of ultrasonic time-of-flight diffraction data to vary the level of noise in the signal and provide estimates of the probability of detection of flaws as a function of the noise level. This concept could be applied to other ultrasonic data. It should be possible to modify the data to add the effects of geometric signals and then evaluate the capability of the UT system to discriminate flaws from geometry. It should also be possible to move the locations of the recorded flaws and geometry signals to make new simulated qualification specimens.

\subsubsection{Risk-based Inspection (ASME Section XI Code Case)}

A proposed alternative to the weld selection criteria of ASME Section XI is the use of riskbased selection rules. A draft code case (Code Case N-XXX, Risk-Based Selection Rules for Class 1, 2, and 3 Piping, Section XI, Division 1) for this alternative is being developed by the Section XI working group on implementation of risk-based examination and is being supported by ASME research. In addition, pilot studies are underway to demonstrate suitability of risk-based technology for inservice inspection. One such study, being performed by the Westinghouse Owners Group at Northeast Utilities' Millstone 3

1 The Code Case $\mathrm{N}-552$ has been adopted by the ASME Boiler and Pressure Vessel Committee and is in the process of publication. plant, is expected to be completed in the first quarter of 1996 (Balkey 1995). Several other pilot studies are also underway and are expected to be completed in the latter part of 1996 or early 1997.

The basis for the Code Case is contained in an ASME Research White Paper entitled Risk-Based Alternative Selection Process for Inservice Inspection of LWR Nuclear Power Plant Components (ASME 1995a), which describes the risk-based selection process as an alternative to the selection sites specified by ASME Section XI. A primary concern with risk-based inspection has been how to implement it in a consistent manner across the nuclear industry. Appendix I Piping Risk-Based Selection Procedure of the white paper contains one approach for implementing a riskbased selection process at a nuclear power plant. This appendix has been incorporated into the draft Code Case to help alleviate concerns regarding the implementation of the risk-based inspection.

The intent of risk-based inspection criteria is to allow ISI examinations to be focused on critical components ${ }^{2}$. Components would be categorized as either high risk-significant or low risksignificant, and would receive examinations commensurate with their risk-significance and the expected failure mechanisms. The result would probably be an overall reduction in the quantity of examinations, but would concentrate activities on components critical to plant safety and areas prone to cracking, such as the counterbore areas in feedwater nozzle welds that currently fall outside the inspection volume required by Section XI.

\subsection{Inservice Inspection of Wall Thinning Caused by Flow-Accelerated Corrosion}

This section summarizes the inservice inspections performed subsequent to the pipe wall thinning (including feedwater pipe rupture) described in IE Bulletin 87-01 (USNRC 1987d). Emerging in-

\footnotetext{
2 For the purposes of this section, critical components are those that have a high failure probability or severe consequences associated with the failure.
} 
service inspection methods for more reliable and accurate estimation of wall thinning are discussed. The criteria and procedures developed for evaluating wall-thinning inspection results are summarized.

\subsubsection{Inspection in Response to Bulletin 87-01}

On December 9, 1986, a main feedwater pipe at Surry Unit 2 experienced a catastrophic failure as a result of wall thinning. In a 1987 refueling outage, wall thinning was also discovered in two straight sections of main feedwater piping at Trojan. Because of these incidents and concerns about high-energy, carbon steel piping systems, the NRC issued Bulletin 87-01, Thinning of Pipe Walls in Nuclear Power Plants, which requested the following information regarding high-energy, carbon steel piping:

a) The Codes and standards to which the piping was designed and fabricated,

b) The scope, extent, and sampling criteria of existing inspection programs to monitor pipe wall thinning of safety-related and nonsafety related systems,

c) Results of inspections performed to identify pipe wall thinning, and

d) Plans for revising existing pipe monitoring procedures or developing new or additional procedures.

The USNRC review of the licensees' responses to Bulletin 87-01 showed that wall thinning in single phase systems (feedwater and condensate systems) is more widespread in PWRs than in BWRs; 26 PWRs and $6 \mathrm{BWR}$ had identified various degrees of wall thinning in the feedwater piping and fittings. The PWR components where wall thinning was reported included elbows, reducers, straight piping runs, drain pump discharge piping, recirculation line, heater vent piping, fittings including feedwater pump suction line fittings, and straight runs including those downstream of the main feedwater loop isolation valves (Wu 1989). These components are listed in Table 7.

The review concluded that limited inspections of single-phase feedwater-condensate systems were conducted at most plants after the incident at Surry Unit 2. The review also found that inspection programs to detect wall thinning in two-phase, high-energy carbon steel piping systems had existed at all the plants. In general, inspection locations were established based on EPRI Document NP-3944, Erosion/Corrosion in Nuclear Plant Steam Piping: Causes and Inspection Program Guidelines, published in 1985. However, because the document guidelines were nonmandatory, there was significant variation in the piping systems included in the program and the number of sites selected for inspection among the plant inspection programs.

The primary inspection methods in response to NRC Bulletin 87-01 were reported to be manual UT, supplemented by visual examination of the inner surfaces of piping components. There were several cases where radiography was also used. Visual inspection is performed by direct observation through an opening in the piping system with borescopes and fiberscopes, and with crawlers that normally have television cameras. Use of crawlers generally requires that the piping system is drained of water. The advantage of performing visual examinations is that larger surface areas can be inspected rapidly if an access to the interior of the piping system is available; for example, through a disassembled valve or an inspection port. Visual examination can reveal the presence of worn areas but is not well suited for observing the wall thinning that occurs in singlephase flow. Visual examination is typically limited to the inside surface of the large diameter piping (Chexal et al. 1996).

Manual UT has been, and is the most commonly used inspection method for measuring wall thinning because it is relatively inexpensive and accurate. A properly conducted UT examination can estimate the pipe wall thickness within $5 \%$ of the actual value (Chexal et al. 1996). The industry 
practice for using UT to detect wall thinning caused by flow-accelerated corrosion is to draw or overlay a grid and then spot measure the wall thickness at each grid location. The grid size depends upon the pipe diameter; larger grid sizes are used for larger diameter pipes. The grid size varies from about $25 \times 25 \mathrm{~mm}$ to $150 \times 150 \mathrm{~mm}$ (1 $\mathrm{x} 1$ in. to $6 \times 6$ in.). If thinning is found, the common practice is to completely scan each grid space with UT and record the minimum thickness. Use of grids provides data that can be used for estimating long-term trends and also for evaluating the structural integrity of a thinned component.

The UT examinations are usually performed on components that are at an ambient temperature. Occasionally, a UT examination is performed on a component that is not taken out of service and the wall temperatures are higher. This type of examination is referred to as hot UT. Special UT transducers and couplant are used for this examination. The wall thickness measurements made with hot UT are less accurate than those made on components that are at ambient conditions because of the difficulties associated with working in a hazardous environment and the added precautions necessary to make accurate measurements at elevated temperatures (Chexal et al. 1996).

Most often, the examination frequency is based on previous inspection data used to trend flowaccelerated corrosion rates. In systems susceptible to wall thinning, the areas selected for inspection varied from plant to plant but were usually areas of abrupt changes in flow direction, immediately downstream of significant pressure drops (e.g., at orifices and control valves) and at other fittings that cause perturbations in flow (i.e., at reducers and branch connections). In some cases, the plant operators used EPRI's CHECMATE program to rank the pipe locations prone to flow-accelerated corrosion.

\subsubsection{Emerging Inservice Inspection Methods for Wall Thinning}

Ultrasonic Examinations. As stated above, manual UT is the most commonly used inspection method for the detection of wall thinning because of its accuracy and relatively low cost. It can be adapted to many complex geometries, and it posses no hazard to inspection personnel (as opposed to radiography). The testing can be accomplished using either a digital thickness gage or a standard flaw detector with an A-scan presentation. Digital thickness gages provide an instantaneous thickness measurement without relying on operator interpretation and are effective on clean, uncoated surfaces. However, digital readout devices can have problems in heavily corroded areas and may misrepresent small thinned areas or the edges of larger thinned areas (Fay 1987). This is primarily the result of the roughness of the corroded surface, which tends to scatter the ultrasonic beam and interfere with the automatic gating and measurement scheme of the digital thickness gage. Consequently, an A-scan presentation is still preferred by many inspectors because trained operators can more reliably interpret signal patterns that may be misinterpreted by digital instruments. Fortunately, many equipment vendors have developed compact equipment with both an A-scan display and digital readout, so thickness measurements can be verified using the A-scan presentation. For corroded surfaces such as those with pitting, focused transducers can provide a more accurate and reliable thickness measurement. Because of their smaller beam size, focused transducers examine smaller areas and are less prone to loss from scatter.

Although ultrasonic thickness measurements are widely accepted and used, there are several disadvantages to the ultrasonic method. UT requires direct access to the examination surface. Thus, removal of insulation is required, which is costly and time consuming. Another disadvantage is that manual methods do not provide a permanent inspection record, only a vast number of thickness measurements. In addition, manual UT is operator dependent and prone to error because of varying conditions and operator interpretation. In an independent study performed by Northern States Power (NSP), six experienced operators made thickness measurements on new clean components and corroded components that were removed from service. The results indicated an average error 
spread of $0.36 \mathrm{~mm}(0.014 \mathrm{in}$.) for the new components and average error spread of $0.91 \mathrm{~mm}$ (0.036 in.) for the corroded components (Shankar and Bridgeman 1990).

Automated ultrasonic scanning has also been used to map corrosion. It is less dependent on the operator and provides a permanent record of the inspection (Edelmann and Gribi 1990). Another advantage is that the entire area can be scanned and presented in a C-scan or plan view. This type of presentation displays UT data so that those not familiar with ultrasonic inspection techniques can view, interpret, and visualize trends. The primary disadvantages of automated UT is the higher cost, compared to manual techniques, and more clearance needed for the scanning devices. Field experience has found that automated UT examinations for thickness measurements are too cumbersome and time-consuming for effective use (Chexal et el. 1996). .

Another variation of UT is a multiple element array called PARIS (Portable Automated Remote Inspection System). PARIS is a flexible array that was adapted for characterization of flowaccelerated corrosion damage in steels (Harrington 1988). This array of transducers can conform and acoustically couple to complex geometries (i.e., elbows and tees) automatically with $100 \%$ coverage. Field demonstrations are still needed to validate this approach.

Radiographic Examinations. An alternative to UT thickness measurements is RT. RT is advantageous because it provides a permanent record of the inspection and can be performed while the system is on-line and without any removal of insulation. Radiographic examinations can detect wear, particularly in components with complex geometries, but the examination results are less useful in trending wall thickness over time. The other disadvantages of using RT are the higher cost of implementation for large bore piping and the radiation hazards it presents to plant personnel.

There are generally two methods of performing thickness measurements with conventional radiog- raphy. The first is a direct double-wall shot along with the use of a calibration curve of thickness versus film density as an indication of wall thickness. This method can be used for inspecting larger components and also geometrically complicated regions, which are difficult to inspect with UT. The second is tangential beam radiography, as shown in Figure 64. A technical limitation of using either of these RT techniques is that multiple shots are required to make measurements around the entire circumference. Therefore, achieving $100 \%$ coverage is a time-consuming process. However, for small diameter piping [for example, diameter less than $150 \mathrm{~mm}$ (6 in.)], tangential beam radiography has been found more economical than ultrasonic examinations.

Radiography of larger size components is limited by the strength of the source. Linear accelerators such as the miniature linear accelerator (MINAC) developed by EPRI can be used as a source for the inspection of larger size components. For example, the tangential beam radiography with an Iridium 192 source has been used for inspecting up to $200-\mathrm{mm}$ (8-in.) diameter pipes, and with a linear accelerator it has been used for inspecting larger up to 450 -mm (18-in.) diameter pipes (Chexal et al. 1996).

The most accurate method of displaying radiographic data is computed tomography, with which a complete cross-section of a component can be obtained. The Japan Power Engineering and Inspection Corporation (JAPEIC) is developing computed tomography to reliably look inside components to obtain dimensions and characterize complex geometries (Maeda 1991). Additional work has been performed to make the system more compact and to enhance image quality, so that flaws can be easily discriminated (Miyoshi, et al. 1992). This information is used as an aide in evaluating indications detected during inservice inspections. This same methodology could also be used to characterize wall-thinning damage in the feedwater piping and thermal sleeves. As mentioned in Section 6.4.2, thinning of the thermal sleeves at Diablo Canyon has occurred. Since conventional ultrasonic techniques are currently not effective, owing to the gap between the pipe 


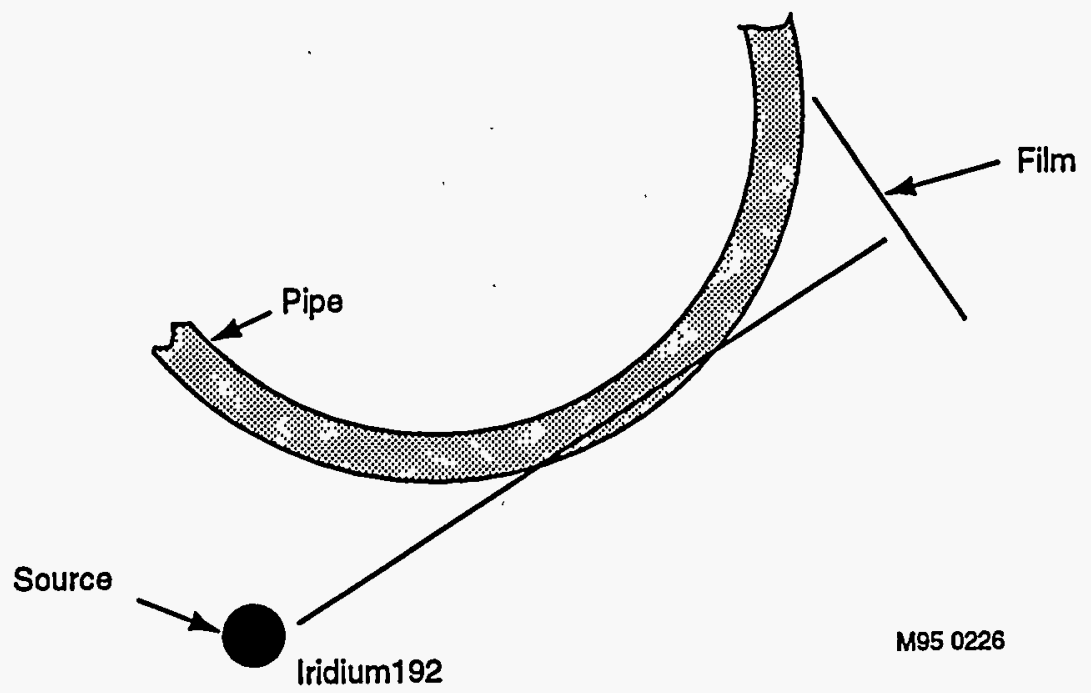

Figure 64. Tangential radiography.

wall and the thermal sleeve, computed tomography may offer a solution to this inspection problem. The disadvantage of computed tomography is the high cost and potentially long processing time to create an image. However, advances in computerized systems are reducing processing time and cost and making tomography a more viable approach for nuclear power plant applications.

Another radiographic technique suggested for use in wall thinning inspection is compton backscatter imaging (Lee and Kenney 1992). Compton scattering is a direct interaction of the incident radiation with orbital electrons of the material under test. The resulting photon energy is scattered in all directions at a lesser energy and wavelength and is monitored with detectors on the same side of the component as the source. The degree of scattering varies directly with atomic number (Metals Handbook 1989). The obvious advantage of this tech- nique is that access to the far side or inside of the pipe is not required. In addition, removal of insulation can be avoided. This technology has been used to examine aircraft components (Lawson 1995), and at least one commercially available system (COMSCAN) ${ }^{1}$ has been developed which is used primarily for lightweight airframe materials. For steels, the use of this technique presents practical problems due to greater absorption losses and reduced resolution. Thus, because of the difficulties working with steel and high implementation cost, compton backscatter has not yet gained widespread acceptance as a reliable field inspection tool. However, because of the potential advantages and benefits, additional investigation is warranted.

1 COMSCAN is Philips' trade name for its Compton $\mathrm{X}$-ray Backscatter Inspection System. 
The EPRI NDE Center is currently looking for technology improvements that will make flowaccelerated corrosion inspection better, faster, and cheaper. ${ }^{1}$ Because radiographic examination has a potential to provide these advantages, EPRI is looking at technologies employing this examination method that will reduce inspection times, safety hazards and costs, while improving the quality of inspections. One approach is the use of a real time radiography (RTR) system that employs multiple detectors to perform double-wall thickness measurements through insulation. The current effort is aimed at adapting the system to work on complex geometries such as elbows and tees, and to add the capability of making tangential measurements. A second approach is the use of phosphor plates in lieu of film. Phosphor plates are expected to reduce exposure time or radiation intensity by a factor of 20 , which can significantly reduce inspection time and/or personnel safety concerns associated with performing RT within a plant. Use of phosphor plates is now being evaluated in the field.

Other Inspection Methods for Wall Thinning. The Transient Electro-Magnetic Probe (TEMP) was developed by ARCO for monitoring general wall thinning in piping and tanks in the petro-chemical industry (Walker and Martinez 1994). TEMP monitors the decay of an eddy current pulse within the wall and has been used successfully by ARCO as a high speed survey tool. ${ }^{2}$ An earlier EPRI evaluation of this probe concluded that TEMP could reliably measure wall thickness to within $5 \%$ for uniform thinning through insulation, but could not detect localized thinning of an area as large as $130 \mathrm{~mm}$ (5 in.) in diameter. Detection of local thinning would require the probe head to be redesigned and the measurement algorithm to be modified. TEMP has been licensed to an inspection equipment vendor,

${ }^{1}$ A. M. Porter, private communication with Steve Kenefick at the EPRI NDE Center, December 12, 1995.

${ }^{2}$ A. M. Porter, private communication with James E. Mitchell of ARCO, November 23, 1995 .
Röntgen Technische Dienst B.V. (RTD), for commercialization of the technology. TEMP is no longer being evaluated by EPRI.

\subsubsection{Wall-Thinning Inspection Criteria}

Once the inservice inspection is completed, an evaluation must be made as to whether the piping is acceptable for service for the next full duty cycle. This evaluation must consider the measured thickness, the flow-accelerated corrosion rate, the factors affecting the corrosion rate, the projected operating time before the next inspection, and the requirements for minimum wall thickness.

EPRI has developed a three-step process for evaluating flow-accelerated corrosion damage that includes: (a) screening to determine if further evaluation is warranted, (b) comparison of any general wall thinning with the design minimum wall thickness requirements, and (c) evaluation of any local wall thicknesses less than the design minimum based on three alternate acceptance criteria (Gerber et al. 1989). The acceptability of any local wall thinning is based on the axial extent of the corrosion-induced thinning along the pipe length, branch reinforcing requirements, and local membrane stress rules.

Hoemann and Berak (1989) developed a three-stage evaluation procedure, based partly on the EPRI method, using a combination of UT results and analysis. In the first stage, ultrasonic measurements are taken using a coarse grid network extending approximately one pipe diameter upstream and two diameters downstream from the component of interest. The component is judged to be acceptable if the lowest ultrasonic measurement shows that wall thickness will remain above the minimum required thickness by the next inspection period. If the Stage 1 criterion is not met, areas around low readings are reexamined, using a reduced grid size, and a combination of ultrasonic measurements and analysis is used to evaluate the area. If the component cannot then be qualified, fracture mechanics and limit load analyses are performed. Of the piping components evaluated as part of the analysis, $47 \%$ were found to be acceptable during initial evaluation, $41 \%$ required further 
analysis to satisfy acceptance criteria, and $12 \%$ required repair or replacement.

ASME Code Case N-480 also presents acceptance standards based on the EPRI evaluation process for pipe wall thinning caused by flow-accelerated corrosion (ASME 1990). If the pipe thickness is less than $87.5 \%$ of the nominal pipe wall thickness, the pipe must be repaired or replaced unless an analytical evaluation shows that an acceptable safety margin exists. Also, if the piping component predicted wall thickness at the next inspection is less than $87.5 \%$ of the nominal wall thickness, pipe repair, replacement, or acceptance by analytical evaluation is required for continued service. The Code Case requires that the component be repaired or replaced if the predicted wall thickness of a piping component at the next inspection is calculated to be less than $30 \%$ of the nominal wall thickness. The analytical evaluation procedure has three alternate requirements for acceptance of any local wall thinning which are a function of depth and extent of the area thinned by flow-accelerated corrosion. If an analytical evaluation is required for areas damaged by flowaccelerated corrosion and the requirements for acceptance of local wall thinning are satisfied, the affected areas should be examined during the next three inservice examinations, at a frequency determined by a flow-accelerated corrosion rate estimated from the inservice examination results.

\subsubsection{USNRC Audits and Inspections}

As discussed in Section 8.3.1, the USNRC issued Bulletin 87-01 because of the catastrophic failure of the main feedwater piping at Surry Unit 2 and the wall thinning of the straight sections of feedwater piping inside the containment at Trojan, both caused by flow-accelerated corrosion. ${ }^{1}$ The inspections performed by the NRC licensees in response to the bulletin are also summarized in Section 8.3.1. Since publishing the bulletin, the USNRC staff have made several visits to selected

1 The term erosion/corrosion instead of flowaccelerated corrosion is generally used in the USNRC information notices, bulletin, generic letter, letters, and reports.
PWRs to assess the licensees' efforts toward implementing their flow-accelerated corrosion monitoring programs. The results of those visits are summarized here (Taylor 1995).

The USNRC staff audited 10 plants during 1988 , 7 PWRs and 3 BWRs. The major finding of these audits was that all the licensees had performed initial inspections for estimating the wall thinning caused by flow-accelerated corrosion and had programs that meet the intent of the industry guidelines for monitoring this damage. However, these were short-term programs and not all the licensees were committed to implementing administrative controls and formalized procedures needed for long-term monitoring. For example, in many instances, the record keeping that would allow for future reproducibility of grids identifying the inspection locations and trending of wall thickness reductions was nonexistent. Also, in several instances where outside contractors performed the inspections, the contractor's guidelines rather than licensees' guidelines were followed; this may lead to inconsistency in the future (Wu 1989).

In response to this finding, the USNRC issued Generic Letter 89-08, Erosion/Corrosion-Induced Wall Thinning, specifically requesting the licensees to affirm that they have implemented, or will implement by a specified date, long-term flowaccelerated corrosion monitoring programs to ensure that flow-accelerated corrosion will not lead to unacceptable wall thinning of high-energy carbon steel piping in either single or two-phase systems. The Generic Letter did not specify the scope and content of these programs.

The USNRC staff conducted audits and inspections at 3 PWRs and 5 BWRs at 5 randomly selected nuclear plant sites during the first half of 1992. The main objective of these plant visits was to assess the general response of the nuclear industry to Generic Letter 89-08. The second objective was to evaluate the procedure that provides guidance to the NRC inspectors for inspecting components susceptible to flowaccelerated corrosion. In addition to these audits and inspections, the Region I staff conducted 
supplemental inspections at 10 plants, 5 PWRs and 5 BWRs at 7 nuclear plant sites. The main finding was that all the licensees that were audited had implemented flow-accelerated corrosion programs in accordance with Generic Letter 89-08. However, the following specific findings imply that a number of improvements could be made (Richardson 1992).

- The flow-accelerated corrosion programs varied widely. Some licensees selected ultrasonic examination locations using analytical models which ranked the systems and components for their susceptibility to flow-accelerated corrosion damage, whereas others used engineering judgement.

- Several licensees had excluded the high energy, carbon steel components in the safetyrelated portion of the feedwater and steam generator blowdown systems inside containment from the scope of their flow-accelerated corrosion programs. The components may be located in non-isolable portions of the coolant systems and they should be included in the flow-accelerated corrosion programs.

- Several errors were found in either inputting the proper parameters into a predictive model such as CHECMATE or in calculating Code minimum wall thickness acceptance criteria.

- Some inconsistencies were found in reproducing the inspection grids during subsequent ultrasonic examination of previously inspected components.

- All of the NRC licensees audited had performed repairs or replacement of the carbon steel components which failed to meet the licensee's minimum wall thickness or alternate acceptance criteria. The replacementmaterials varied from carbon steels, to chromiummolybdenum steels, to austenitic stainless steels.

- Some repairs of the safety-related piping worn by flow-accelerated corrosion may not meet code repair requirements. For example, a licensee repaired a worn Class 1 feedwater component inside the containment with a weld buildup on the exterior of the pipe.

- Most licensees did not perform baseline thickness measurements on new or replaced piping prior to placing the piping in service.

The USNRC staff were interested in evaluating the use of engineering judgement by some licensees to choose locations for inspections. It started, therefore, a program where predictions were made using the CHECMATE code and then compared to the licensee's predictions using engineering judgement. The evaluation at one plant is completed and good agreement between the components selected by the NRC staff with the CHECMATE code and those selected by the plant operator with engineering judgement. However, the main concern remains that the component selection based on engineering judgement largely depends on the plant operators experience and, therefore, the selection may vary significantly from plant to plant. Initially NRC planned to continue this program at one more plant. However, this further evaluation may not be needed because all the plants now use the predictive codes for selecting the components for inspection.

\subsection{Inservice Inspections at Non-US Plants}

As discussed in Section 7, fatigue caused by thermal stratification and flow-accelerated corrosion have damaged feedwater piping in non-US plants. Conventional and enhanced inspection techniques have been used to characterize the damage. However, these inspections are not required on a periodic basis in the responding countries. Several non-US countries have provided varying amounts of information about relevant inspection activities carried out at their PWR plants.

\subsubsection{Inservice Inspections of Fatigue Cracks at Non-US Plants}

Several countries use the ASME Section XI Code for detecting and sizing thermal fatigue cracks. 
Some countries have performed inspections based on NRC Bulletin 79-13. Generally, conventional or enhanced manual ultrasonic inspection techniques are used. However, according to the Finnish response, these techniques are not qualified for detection of thermal fatigue cracks, which is the present situation in the whole of Europe. This is also the present situation in other countries, including the United States. Finland has performed volumetric and surface examinations of the complete piping between the feedwater nozzle and the first check valve upstream of the nozzle, including both base metal and welds. These examinations were performed at each of the six steam generators at one plant. No fatigue cracking has been detected outside the inspection areas required by the ASME Code, which include welds and the adjacent base metal. The amplitude drop technique is never used alone for sizing a fatigue crack. Supplemental ultrasonic examination techniques such as PATT or SPOT are always used in parallel.

In Belgium, ultrasonic examination with shear wave probes is used for detecting cracks in feedwater piping welds and the adjacent base metal. The crack-tip-diffraction technique with an angle beam or a straight beam is used to size fatigue cracks in the feedwater piping. If the crack tip diffraction technique is not applicable and the flaw apparently has a small through-wall extent, then the amplitude comparison method is used. In all other cases, the $6 \mathrm{~dB}$ drop method is used. The operator discriminates flaw indications from geometry by using a full-scale sketch of the weld and repositioning the probes and ultrasonic beams.

Advanced ultrasonic methods are being developed in France for detecting and sizing fatigue cracks produced by thermal stratification. Mockup samples and samples from replaced steam generators are used to qualify these methods. Two main difficulties faced in application of these methods are limited access to the zones that have to be inspected and rough surface conditions. It was expected that development and field testing would be completed by the end of 1995 . Gamma radiography inspection is also used at French PWR plants; however, this inspection method has never detected indications in the feedwater systems.

In Switzerland, inservice inspection of the feedwater systems includes weld surface and volumetric examinations performed by magnetic particle testing and UT, respectively. The inspection zone includes the entire volume of the weld and $13 \mathrm{~mm}(0.5 \mathrm{in}$.) of the adjacent base metal on each side of the weld. The crack-tipdiffraction technique is used for crack sizing; however, this technique is not yet qualified. The amplitude-drop method is considered to be unreliable for crack sizing. The discrimination between geometrical and flaw indications is performed by localization of an indication with scanning from both sides of the weld and using additional scanning angles.

Ontario Hydro Nuclear of Canada does not inspect the feedwater lines in its CANDU units for fatigue cracks, possibly because such cracking is considered unlikely. However, if such inspections were to be performed, Ontario Hydro Nuclear would use baseline inspection results, radiography results when applicable, and geometry data for weld joints along with ultrasonic inspections, using special tools such as tip-diffraction techniques coupled with creeping wave probes. These probes are currently being developed and used during the inspections required by the code Periodic Inspection of CANDU Nuclear Power Plant Components to look for surface breaking flaws.

\subsubsection{Inservice Inspections of Wall Thinning at Non-US Plants}

Apparently, wall thinning caused by flowaccelerated corrosion is more wide spread in the non-US plants than fatigue cracking caused by thermal stratification. Each responding country has inservice inspection activities associated with wall thinning. Generally, these inspections are performed with ultrasonic techniques using a gridbased system. In Finland, all the feedwater piping is included in the inservice inspection program. The WATHEC computer code developed by Siemens is used to analyze the system and select 
locations for inservice inspections. In addition to ultrasonic examinations, visual examinations of discontinuities on the inside surfaces, especially the inside surfaces of welds, are performed using a video camera. Supplemental locations, in addition to those recommended by the WATHEC code, are also inspected.

In Belgium, the feedwater system locations to be inspected are selected after taking into account various factors affecting flow-accelerated corrosion: water temperature and $\mathrm{pH}$, flow velocity and diameter of pipe, piping material composition, and local geometry. The following components are usually inspected in the selected piping: all elements downstream of control valves, including valve bodies; all tee fittings and pipe expansion pieces; and $10 \%$ of the elbows, including all elbows in series. Elbows with a large angle are selected over ones with a small angle. Ultrasonic examinations with the use of a transmitter-receiver probe are performed to measure the extent of the wall thinning. Both minimum and average thicknesses are estimated.

Manual ultrasonic examinations are typically performed to detect wall thinning in Swiss PWRs. Selection of inspection areas is made by the utilities, considering recommendations from plant manufacturers and their own experience. No enhanced examinations are performed because no indications of wall thinning in feedwater lines have been found until recently.

Ontario Hydro Nuclear uses manual ultrasonic examination techniques for estimating wall thinning at the Bruce B units. Extensive use of fiberglass templets is made for accurately and efficiently reproducing the grid at each inspection location. The inspection locations are selected and ranked by taking into account the various factors affecting the flow-accelerated corrosion damage including fluid temperature and velocity and piping geometry. Additional factors such as dissolved oxygen concentration and $\mathrm{pH}$ level are considered to prioritize closely ranked components. The Atomic Energy Control Board of Canada reports that the accuracy of the wall-thickness measurement using ultrasonic examinations is on the order of $75 \mu \mathrm{m}$ (0.003 in.).

No significant wall thinning has been found in the Dutch PWR plant because the feedwater system was built with low-alloy steels, and the flow velocities are moderate. In Japan, wall thinning inspections are performed by each utility but they are not required to report the inspection results to the regulatory body. Ultrasonic examinations are used for wall thickness measurements in Spanish PWRs. A typical surveillance program includes inspection of about 75 areas in the feedwater system. 


\section{MITIGATION AND MONITORING OF FATIGUE, FLOW- ACCELERATED CORROSION, AND WATER HAMIMER DAMAGE}

Methods employed to prevent or mitigate thermal fatigue damage are discussed in this section. The methods include modifications to the operating procedures for the feedwater systems and structural design changes of the feedwater piping and other components. We then briefly review the on-line fatigue monitoring of feedwater lines. We follow this with a discussion on the methods employed to prevent or mitigate wall thinning caused by flowaccelerated corrosion. Finally, mitigation methods for water hammer are discussed.

\subsection{Mitigation of Thermal Fatigue Damage}

As discussed in the previous sections of this report, flow stratification in PWR feedwater piping can cause significant thermal fatigue damage. Flow stratification takes place when the incoming feedwater flow rate is low and there is a large temperature difference between the incoming feedwater and the steam generator coolant. Fluctuations in the elevation of the interface between the hot and cold coolants causes thermal fatigue damage. This damage generally takes place at plants where the cold auxiliary feedwater is injected directly into the main feedwater line. Therefore, several plants have modified their operating procedures and made design changes to their feedwater systems to reduce the stresses produced by stratified flows. In addition, new design features have been incorporated in replacement steam generators and in steam generators for new plants so that flow stratification does not take place.

An effective modification to the operating procedure is to use a continuous flow of auxiliary feedwater instead of intermittent flow. This modification does not eliminate stratification or reduce the thermal stresses produced by the stratification but does significantly reduce the number of fluctuations in these stresses and, therefore, the resulting fatigue damage. This change in the operating procedure may require manual operation of the auxiliary feedwater system instead of automatic operation as discussed in Section 6.3.1. Manual operation at the Sequoyah plant, for example, supplies a continuous flow of auxiliary feedwater at a nearly constant flow rate of about 300 to $340 \mathrm{~g} / \mathrm{min}$ ( 80 to $90 \mathrm{gpm}$ ), whereas the automatic operation supplied auxiliary feedwater with a flow rate cycling between 0 and $833 \mathrm{l} / \mathrm{min}(220 \mathrm{gpm})$ at a frequency of about 3 cycles per hour. Thus, the fatigue damage is significantly smaller using the manual mode of operation.

Another effective modification to the plant operating procedure is to use heated main feedwater during plant startup and hot standby conditions. As discussed in Section 2.1, in two Westinghouse plants, Wolf Creek and Callaway, the main feedwater system includes a special startup system that provides heated feedwater to the steam generators during startup, hot standby, and shutdown operations of the plant. Heated feedwater is also used in Japanese PWRs during startup and hot standby. This may be the reason that fatigue cracks have not been found in the feedwater nozzle in the Japanese PWRs since 1974.

Three modifications in the feedwater piping design or layout have also been made to reduce or eliminate the thermal stresses produced by stratified flows. These modifications include a redesign of the counterbore to remove the stress raiser, installation of a thermal liner to protect the counterbore and other susceptible sites from thermal fatigue damage, and a modified piping layout to introduce the auxiliary feedwater directly into the steam generator instead of into the main feedwater line. The end of the feedwater nozzle can be built up with weld metal so there is no change in wall thickness from the feedwater nozzle to the transition piece; this modification eliminates the counterbore, a stress raiser, where fatigue cracking has occurred at several PWR plants. An example of this type of modification is shown in 
Figure 31. Installation of a thermal liner that protects the counterbore region, feedwater nozzle, and adjacent piping and elbow from the flow stratification stresses is shown in Figures 13 and 30.

The feedwater piping layout was modified at the Palisades plant to introduce the auxiliary feedwater directly into the steam generator, after finding cracks in the main feedwater nozzle in 1979. The Palisades steam generators had originally been designed with an auxiliary feedwater nozzle located some distance above the main feedwater nozzle and connected to the auxiliary feedwater distribution system including a thermal sleeve and a sparger inside the steam generator. However, the auxiliary feedwater nozzle was capped during installation and the auxiliary feedwater piping was instead connected to the main feedwater piping. The piping layout modification performed after the 1979 cracking event included connecting the auxiliary feedwater piping to the auxiliary feedwater nozzle as originally planned. However, this layout modification led to a water hammer event in the auxiliary feedwater system and various components were damaged as discussed in Section 6.5. Another concern with this modification is the possible leakage of the auxiliary feedwater into the gap between the auxiliary feedwater nozzle and thermal sleeve and the resulting fatigue damage to the nozzle. Such damage to an auxiliary feedwater nozzle has been reported at one plant (Westinghouse 1989).

Several design changes have been made in the steam generators designed by Siemens/KWU to reduce or eliminate the possibility of flow stratification taking place. Flow stratification occurred in the horizontal portion of the main feedwater piping attached to the original Siemens steam generators when the flow rate of the main feedwater was low, as shown in Figure 65. This caused cracking in the heat-affected zone and in the base metal near the weld between the feedwater nozzle and the piping (Braschel, Miksch, and Schucktanz 1984). To prevent flow stratification from taking place, an upward bend has been incorporated in the piping connecting the thermal sleeve to the feedring inside the steam generator as shown in Figure 66.
Two other design changes in the Siemens/KWU steam generators include: (a) distribution of the cold auxiliary feedwater through a spraying device located in the main feedwater pipe upstream of the feedwater nozzle, which mixes the cold auxiliary feedwater with the hot water present in the horizontal pipe, and (b) installation of a recirculation loop to inject a part of the steam generator blowdown flow back into the feedwater line upstream of the feedwater nozzle.

The flow stratification phenomenon has been avoided in some new or replacement steam generators by diverting the auxiliary feedwater flow directly into the steam generator through a separate smaller diameter nozzle. This arrangement eliminates the thermal stratification conditions in the main feedwater nozzle and adjacent piping. In addition, it does not result in thermal stratification in the auxiliary nozzle because of its smaller diameter.

The flow stratification phenomena was also avoided in some new or replacement steam generators by installing an antistratification device that breaks down the stratification by mixing the hot and cold coolants. Framatome developed such an antistratification device, called a helix, consisting of a central hub and four helical blades, extending from the hub to the sleeve inner wall, as shown in Figure 67 (Slama 1994). Each blade makes 1.35 revolutions and is welded to the inner wall of the thermal sleeve and to the hub. A helix was installed in the replacement steam generator for Beznau Unit 1. Field test results showed that stratification does not take place even in the presence of cold feedwater $\left[40^{\circ} \mathrm{C}\left(104^{\circ} \mathrm{F}\right)\right]$ flowing at less than about $600 \mathrm{l} / \mathrm{min}$ (159 gpm).

\subsection{Fatigue Monitoring of Feedwater Lines}

The flow rate and temperature of the feedwater are relatively constant through the feedwater system during power operation. However, during startup and hot standby operations (Modes 2 and 3, respectively) when auxiliary feedwater is injected, the flow rate and temperatures may fluctuate. Reasonable estimates of these two parameters can 


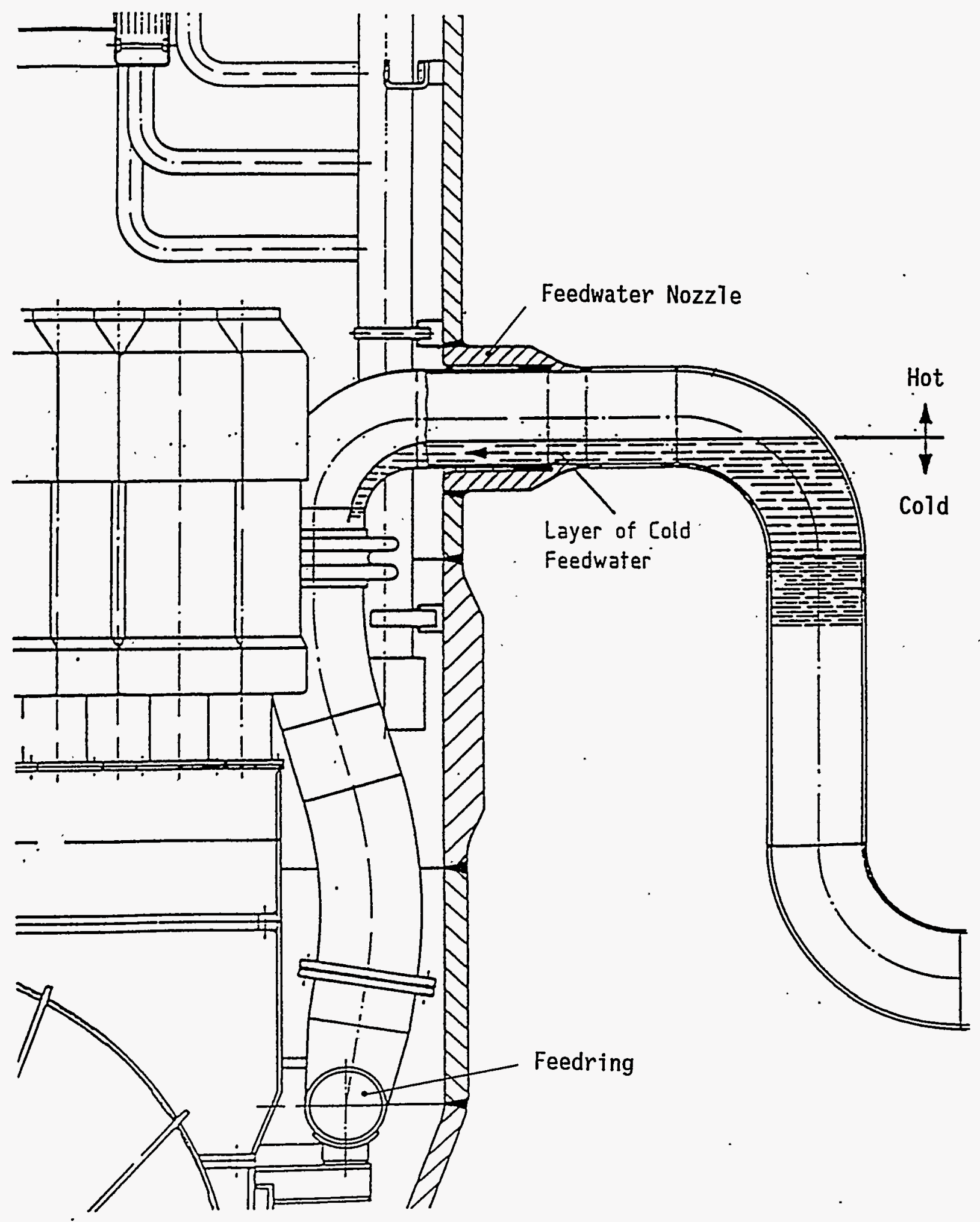

Figure 65. Original layout of the feedwater distribution piping inside Siemens/KWU steam generators. Courtesy of P.-J. Meyer, Siemens/KWU. 


\section{MITIGATION AND MONITORING}

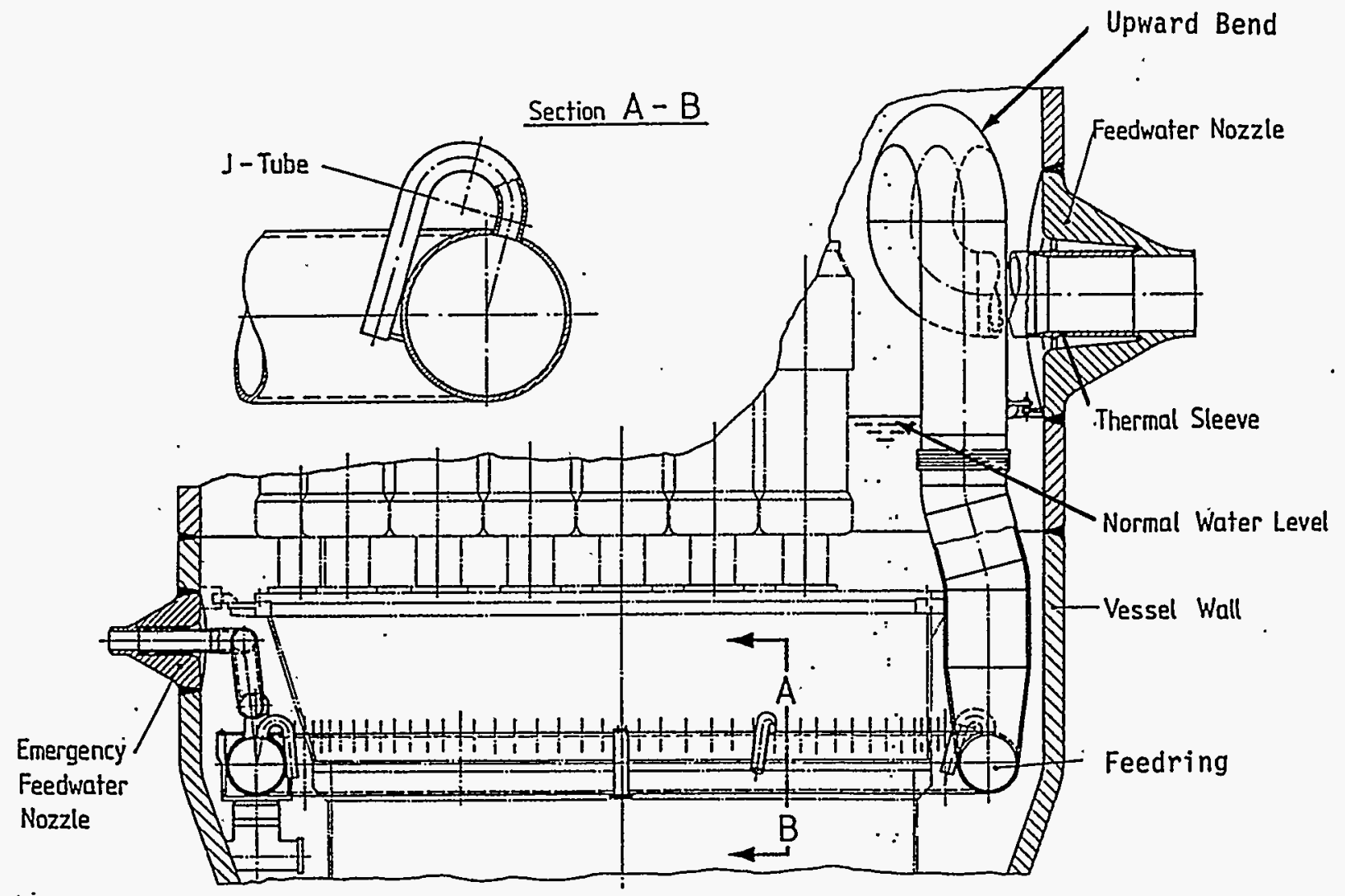

Figure 66. Modified layout of the feedwater distribution piping inside Siemens/KWU steam generators. The upward bend in the piping prevents flow stratification. Courtesy of P.-J. Meyer, Siemens/KWU.

only be obtained by on-line monitoring. A circumferential distribution of the feedwater pipe wall temperatures must be measured to determine the presence and extent of the thermal stratification; such monitoring of a local temperature distribution is sometimes referred to as local fatigue monitoring. The measured temperatures can be used to calculate the thermal stresses caused by stratification and, then, to estimate the fatigue usage for the piping and nozzles. This information can also be used as part of an overall plant on-line fatigue monitoring program. The calculated thermal stresses can also be used for estimating the growth of existing cracks.
Local fatigue monitoring of feedwater piping has been performed at several U.S. and foreign nuclear power plants and the information used to estimate the auxiliary feedwater flow rates and temperatures during startup and hot standby operations. The online fatigue monitoring system installed at Diablo Canyon Unit 1, Steam Generator 2, provides a typical example. RTDs were attached to the outside surface of the feedwater nozzle-to-pipe weld underneath the insulation, as shown in Figure 68 (Shvarts et al., 199.4). Data were acquired once per minute for a twelve day period during a plant heatup. In addition, data for five plant process parameters (feedwater pressure, 


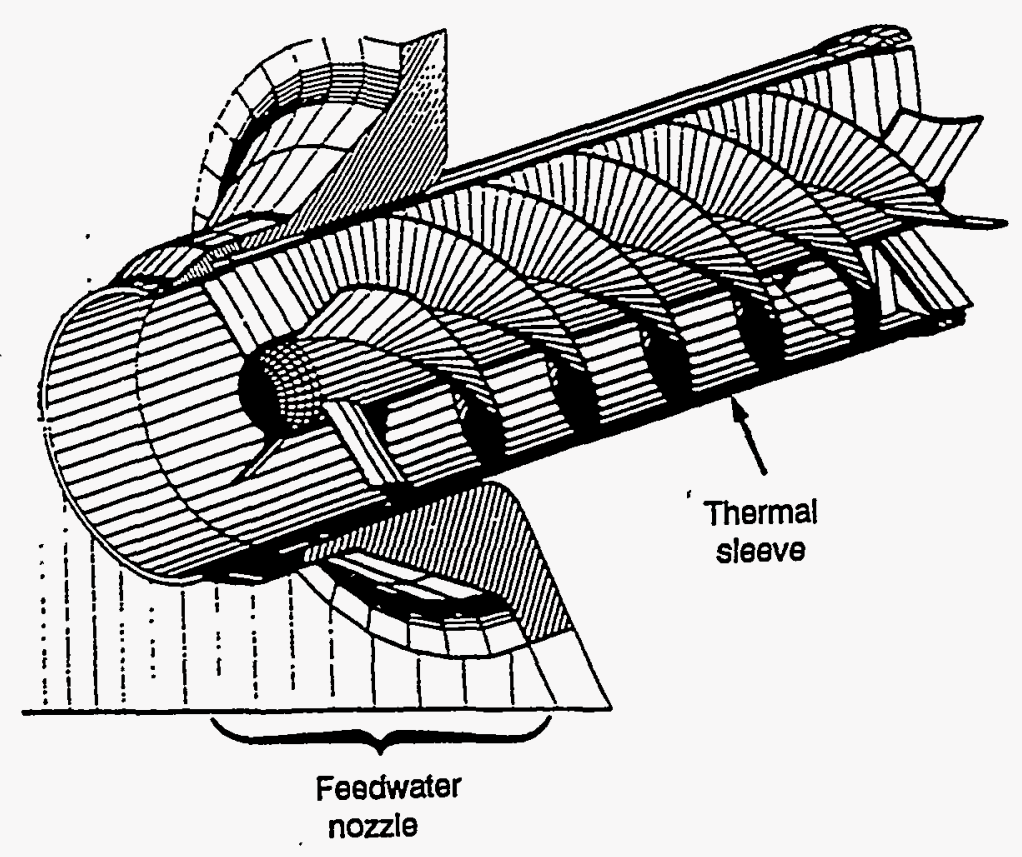

Figure 67. Antistratification device for effective mixing of hot and cold coolants in the feedwater nozzle (Slama 1994). Copyright Canadian Nuclear Society; reprinted with permission.

temperature, and flow rate; auxiliary feedwater flow rate; and reactor coolant loop 2 temperature) were collected for the same time period at the same time intervals. The nozzle region was subjected to thermal stratification with a maximum top-tobottom temperature difference of approximately $232^{\circ} \mathrm{C}\left(450^{\circ} \mathrm{F}\right)$ for about $3 \frac{1}{2}$ days. The steam generator was fed exclusively with auxiliary feedwater during this time period. Then the main feedwater flow was established and the auxiliary feedwater flow was terminated during Mode 2 operations and there was no stratification.

Figure 69 shows typical data from five of the nine RTDs and also the auxiliary feedwater flow rate over a 33-hour period. A finite element analysis was used to determine the height of the interface layer of the stratified coolant that would match the measured temperature distribution at the outside surface. Four parameters were varied for this analysis: the inside surface convective heat transfer coefficients for the hot and cold coolants, and the height and width of the thermal stratification interface. Thus a correlation between the auxiliary feedwater flow rates and the height of the interface layer was established. However, the correlation will vary from plant to plant because of differences in the piping layouts including feedring arrangements and in the coolant temperatures and flow rates. The data gathered from the fatigue monitoring system were used for the design of new transition pieces for the Diablo Canyon feedwater nozzle.

Similar fatigue monitoring systems have been in intermittent operation at the Sequoyah plants since 1991 (Cofie et al. 1994). The data were used to evaluate the flaws found in the Sequoyah plant in 1993. The data gathered from these monitoring systems can also be used by plant operations personnel to limit auxiliary feedwater cycling and thereby reduce crack growth. 


\section{MITIGATION AND MONITORING}

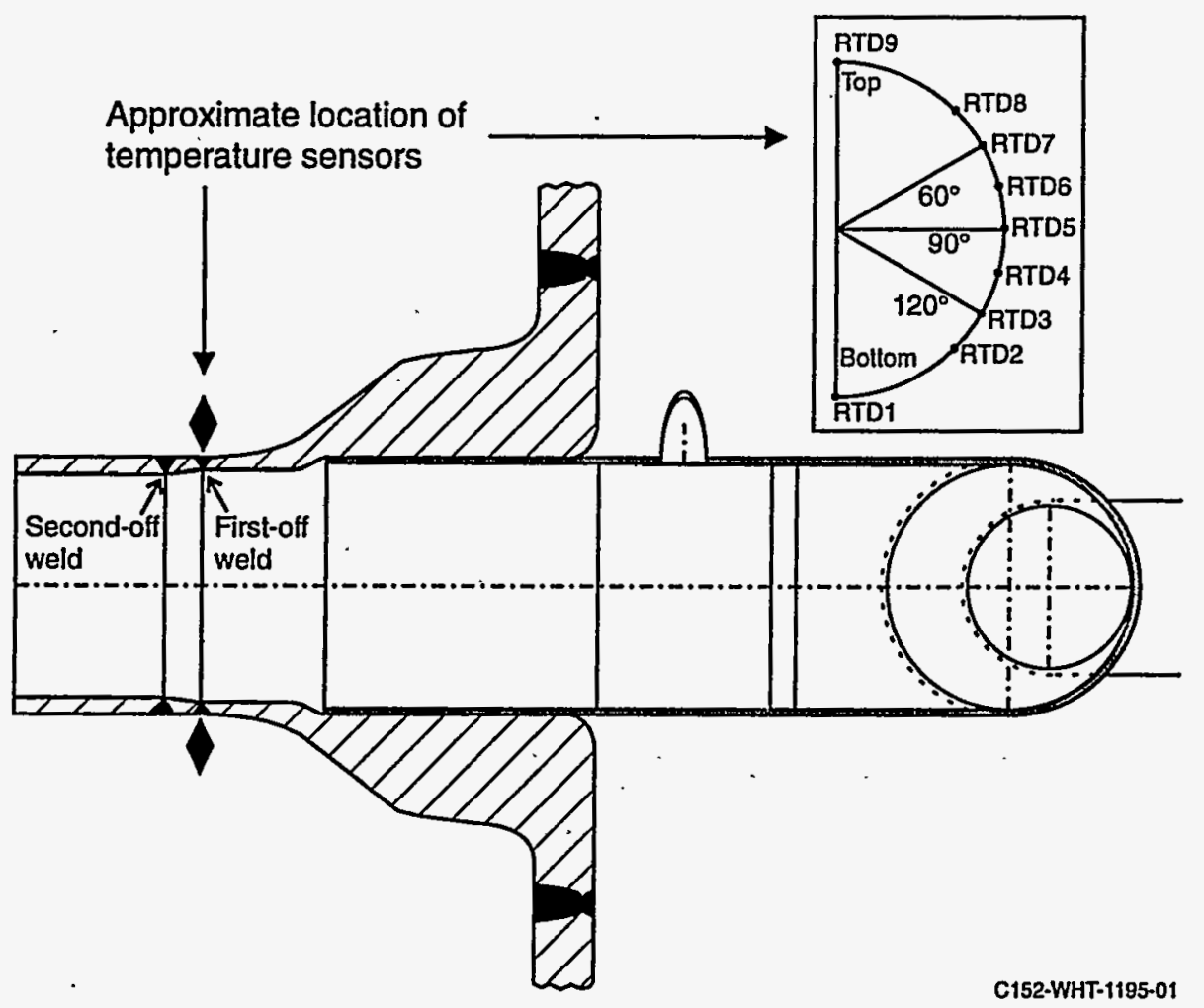

Figure 68. Local on-line fatigue monitoring of feedwater nozzle-to-pipe weld at Diablo Canyon Unit 1 (Shvarts et al. 1994). Copyright American Society of Mechanical Engineers; reprinted with permission.

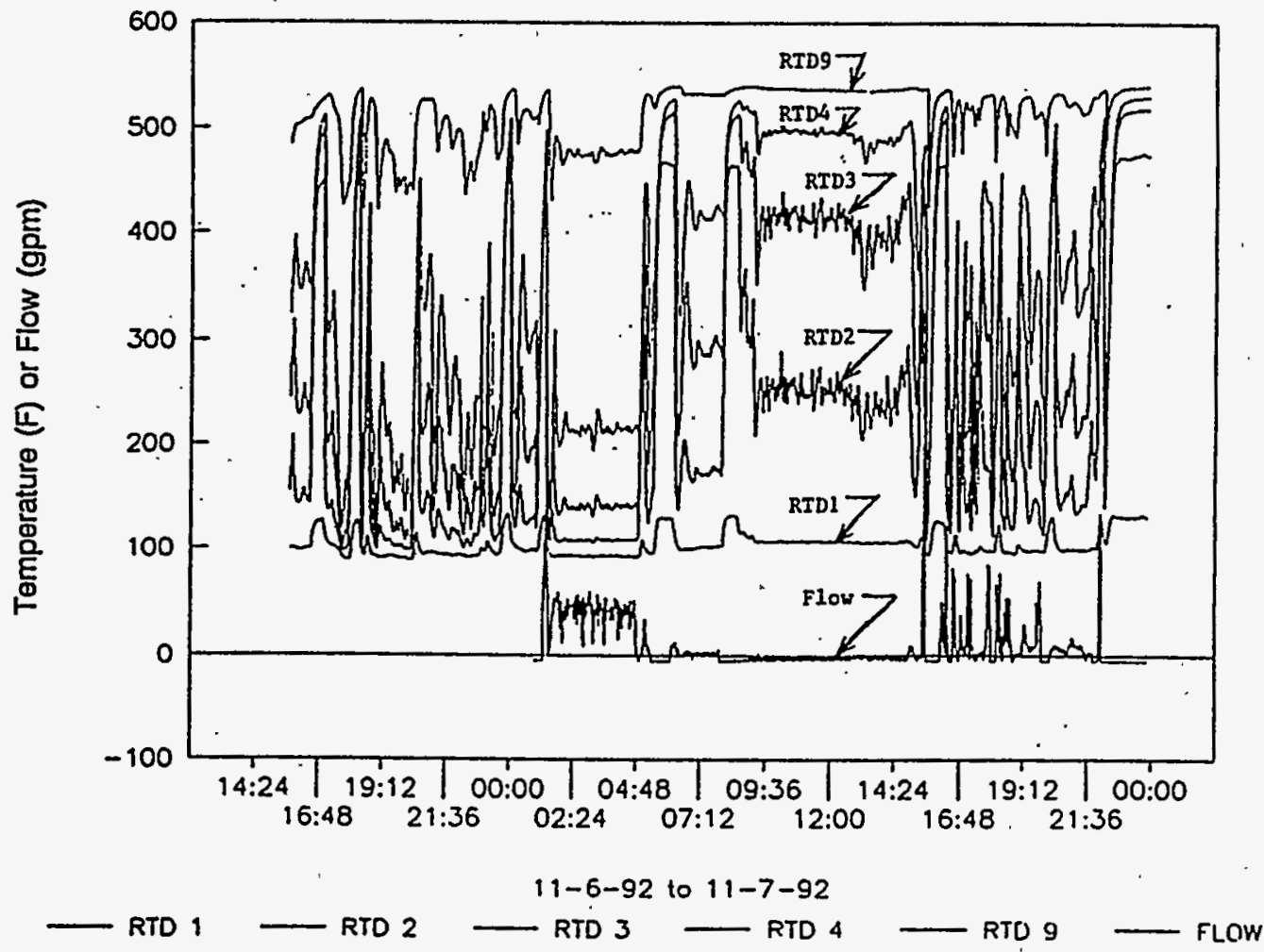

Figure 69. Local on-line fatigue monitoring results for feedwater nozzle-to-pipe weld at Diablo Canyon Unit 1 (Shvarts et al. 1994). Copyright American Society of Mechanical Engineers; reprinted with permission. 
Local monitoring of a long horizontal section of the feedwater piping at Beaver Valley Unit 1, a Westinghouse 3-loop plant, was performed following a reactor trip at 29\% power (USNRC 1991c; Van Duyne et al. 1991). The reactor trip event was followed by the injection of cold auxiliary feedwater at $10^{\circ} \mathrm{C}\left(50^{\circ} \mathrm{F}\right)$ into the main feedwater, which was at $168^{\circ} \mathrm{C}\left(335^{\circ} \mathrm{F}\right)$. The auxiliary feedwater flow rate was $1,400 \mathrm{l} / \mathrm{min}$ (370 gpm) per steam generator. The feedwater piping is particularly susceptible to global thermal stratification because it contains a long horizontal run inside the containment, and its connection to the auxiliary feedwater line is located outside the containment. However, it had not previously been identified as subject to thermal stratification. The instrumentation included 12 thermocouples, 5 strain gages, 8 lanyard potentiometers (to measure displacement), 1 pressure transducer, and 1 linear variable differential transformer (LVDT). Locations of these instruments are shown in Figure 70. The six thermocouples mounted around the circumference of the pipe at two locations detected a top-to-bottom temperature difference that varied by as much as $110^{\circ} \mathrm{C}\left(200^{\circ} \mathrm{F}\right)$. Flow stratification was estimated to occur when cold fluid, such as auxiliary feedwater, is injected into the system at flow rates of $3,800 \mathrm{l} / \mathrm{min}(1,000$ $\mathrm{gpm}$ ) or less per steam generator. Stratification has also been observed during power reductions to levels below $30 \%$ and a subsequent reduction in the feedwater flow rate.

\subsection{Mitigation of Flow- Accelerated Corrosion Damage}

Several carbon steel components in the PWR feedwater systems have experienced material loss due to flow-accelerated corrosion, as discussed in Section 6.4. The components which have been damaged by flow-accelerated corrosion include elbows, tees, branch connections, reducers, valves, flow control orifices, etc. in the feedwater piping outside the steam generator, and J-tubes, feedrings, and thermal sleeves in the feedwater distribution piping inside the steam generator. The damage caused by flow-accelerated corrosion can be reduced in a number of ways, including use of op- timized feedwater chemistry, use of replacement materials with a chromium content greater than 0.1 $\mathrm{wt} \%$, and other modifications such as reducing the flow velocity or protecting the susceptible material from being exposed to large flow velocities. As discussed in Section 7.2.2, two other reasons for reducing the flow-accelerated corrosion rates are to reduce the amount of corrosion products transported to steam generators and to reduce the fouling of the condensate polishers.

\subsubsection{Optimized Feedwater Chemistry}

Flow-accelerated corrosion rates vary by an order of magnitude over the cold $\mathrm{pH}$ range of 8.5 to 9.5, which is typical of feedwater systems. The rate increases rather dramatically when the cold $\mathrm{pH}$ is below about 9.5 . Therefore, a relatively high feedwater cold $\mathrm{pH}$ is beneficial in reducing the extent of flow-accelerated corrosion damage. However, as discussed in Section 7.2.2, high cold $\mathrm{pH}$ levels are not compatible if copper alloy materials are present in the condensers and feedwater heaters because of corrosion of copper alloy materials. Also, high cold $\mathrm{pH}$ levels are not desirable if the condensate polishers are present and continuously in operation because the regeneration frequency will be high.

An optimum $\mathrm{pH}$ and water chemistry in a PWR secondary steamwater system is generally achieved by the addition of amines such as ammonia, morpholine, and ethanolamine in the demineralized water. For feedwater systems with copper alloy materials, a cold $\mathrm{pH}$ level in the range of 8.8 to 9.2 should be maintained to prevent excessive copper pickup. Morpholine is widely used in these systems (all French PWRs and several U.S. PWRs) to maintain a cold $\mathrm{pH}$ in the range of 9.1 to 9.3 , provided the condensate polishers are absent. Along with the use of morpholine, a low concentration of hydrazine is used to lower the dissolved oxygen content in the feedwater.

Systems with an absence of copper alloy materials can maintain a higher cold $\mathrm{pH}$ level to reduce the flow-accelerated corrosion of carbon steel components. If ammonia is used for $\mathrm{pH}$ control in 

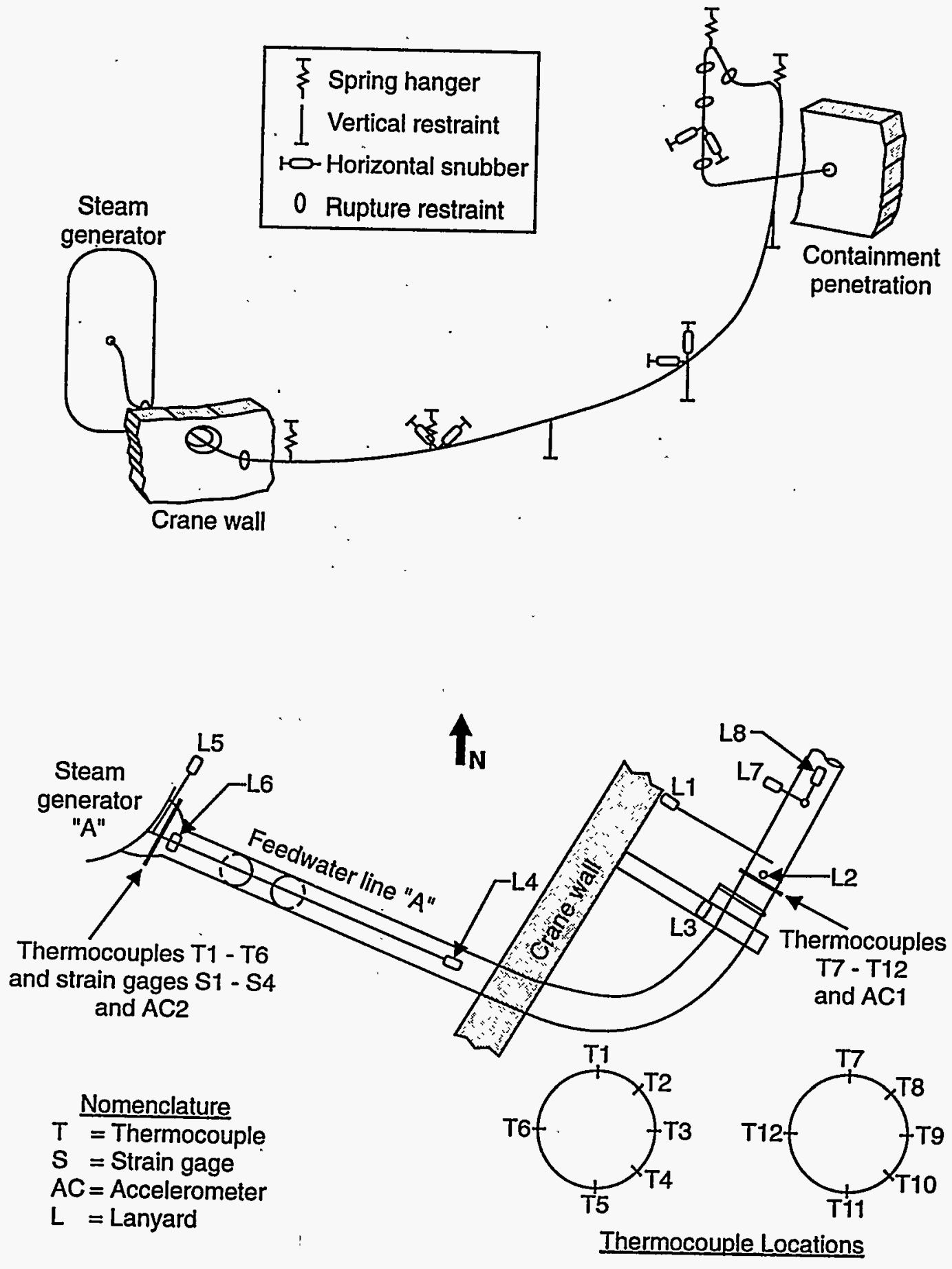

C152-WHT-1195-02

Figure 70. Local on-line fatigue monitoring of Beaver Valley Unit 1 feedwater line (USNRC 1991c). 
these PWR feedwater systems, the cold $\mathrm{pH}$ should be increased, at least up to 9.7, to avoid flowaccelerated corrosion provided that the condensate polishers are not in continuous operation.

As discussed in Section 7.2, test results have shown that ethanolamine is effective for the entire secondary system, including both the single-phase and two-phase flow regimes. Use of ethanolamine is also compatible with the continuous operation of the condensate polishers. In addition, the corrosion product transport with ethanolamine is lower than that with ammonia and even lower than that with morpholine. A large number of U.S. plants are currently switching or contemplating switching to this amine or a combination of several amines.

Despite these feedwater conditioning enhancements, use of the most effective reagent or combination of reagents for feedwater conditioning will not completely eliminate the risk of wall thinning during long-term operation, such as a 40-year operation. Research results show that the maximum wall thinning rates are still about 0.1 to 0.2 $\mathrm{mm} / \mathrm{yr}(0.004$ to $0.008 \mathrm{in}$./yr), even when the water chemistry is optimum (Bouchacourt et al. 1994). Therefore, comprehensive, exhaustive, and conservative analyses of the feedwater system need to be performed to identify all sites susceptible to flowaccelerated corrosion and these sites need to be inspected periodically for wall thickness loss.

\subsubsection{Use of Corrosion Resistant Materials}

The risks of wall thinning can be significantly reduced if the susceptible sections of the feedwater piping are replaced with piping made from materials, such as SA-335 Grade P11 and P22 steel and Type 304 stainless steel, with a higher chromium content. The experience at the Diablo Canyon plants show that flow-accelerated corrosion of carbon steel components took place only if the chromium content was less than 0.1 wt\%, as discussed in Section 7. Several PWR plants have made such replacements. For example, the replacement steel piping at Surry Unit 1 contains 2.5 wt $\%$ chromium.
The availability of the material, allowable stresses and thermal expansion coefficient of the material, and required heat treatments play a role in selecting the replacement material. The P11 steel tends to be less available than P22 steel. The allowable stress and the thermal expansion coefficients for the SA-335, Grade P11 and P22 steels are similar to those for carbon steels, and a new stress analysis is, therefore, not normally required. However, pre- and post-weld heat treatment is usually required (Chexal et al. 1996).

Type 304 stainless steel is widely available but its allowable stress is lower than that of carbon steel and its thermal expansion coefficient is greater. Therefore, a new stress analysis is required when an appreciable length of carbon steel piping is replaced with stainless steel piping. Another difficulty with the use of stainless steel is the special precautions required for making the bimetallic welds between the stainless steel and carbon steel sections of the piping. In addition, the susceptibility of the stainless steel piping to stress corrosion cracking needs to be considered.

Similarly, carbon steel piping with a stainless steel cladding or coating on the inside surface is immune to flow-accelerated corrosion. A three-layer stainless steel coating designed to prevent flow-accelerated corrosion damage to carbon steel piping was developed and successfully applied to pipes containing wet steam at 10 power plants in Europe, $6 \mathrm{BWRs}$ and 4 PWRs (NEI 1989). The first application was in a BWR plant in 1977. The coating is flame-sprayed on the interior of the piping. The top layer is Type 304 stainless steel, which is very resistant to flow-accelerated corrosion. The bottom layer is chosen to provide a sufficient mechanical bond to the carbon steel pipe, and an intermediate layer provides bonding between the top and bottom layers. The total thickness of the three layers is usually about 0.5 $\mathrm{mm}(0.020 \mathrm{in}$.). In situ application requires a minimum pipe diameter of about $600 \mathrm{~mm}$ (24 in.), whereas shop application requires a minimum pipe diameter of about $100 \mathrm{~mm}$ (4 in.). A similar coating can be applied to the feedwater piping, which carries single-phase fluid. Similarly, carbon 
steel piping clad with stainless steel will provide protection against flow-accelerated corrosion.

Several other carbon steel components in the feedwater distribution system have also been replaced with components made from corrosion resistant steels. The carbon steel J-tubes have been replaced with Alloy 600 ( $16 \mathrm{wt} \% \mathrm{Cr}$ ) J-tubes in all the Westinghouse steam generators. In some Combustion Engineering plants, the carbon steel discharge elbows have been replaced with elbows made of P22 steel. In some Combustion Engineer-, ing plants, the distribution box has experienced local thinning and has been repaired with weld buildup, whereas in some other plants the damaged distribution boxes were replaced with ones made of Alloy 690 , which has a chromium content of about $30 \mathrm{wt} \%$.

\subsubsection{Other Modifications}

The role played by high flow velocities was not recognized at the time of the J-tube failures. So, in some instances, installation of the replacement Jtubes led to a geometric discontinuity at the inside surface of the feedring around the entrance to the J-tubes. As shown in Figure 37(a), this discontinuity resulted in high flow velocities that caused wall thinning of the feedring in one PWR plant. The feedring was repaired and the J-tube design and installation were modified to lower the flow velocities. The modification included an Alloy 600 reducer welded to the feedring to lower the flow velocity. The reducer is ground flush with the feedring inside diameter to reduce turbulence, as shown in Figure 37(b).

Wall thinning of thermal sleeves has been reported at some plants. The possible reason is damage to the leading edge of the sleeve caused by impingement of feedwater on its square edge, followed by flow-accelerated corrosion of the outside surface of the sleeve caused by the high flow velocity of the bypass coolant leaking through the gap between the sleeve and the feedwater nozzle. As shown in Figure 38, in one PWR plant, a redesigned transition piece was installed so that a leading edge is not exposed to the flowing feedwater. The chromium content in the transition piece and other replacement components was kept higher than $0.1 \mathrm{wt} \%$ to mitigate any future flow-accelerated corrosion damage. The thermal liners installed in several feedwater nozzles (see Figure 30) for protecting the feedwater nozzle and elbow from thermal stratification also protect the leading edge of the thermal sleeve from being exposed to flowing water.

\subsection{Mitigation of Steam Generator Water Hammer Damage}

Over 30 steam generator water hammer events have been reported in the PWR feedwater piping, as summarized in Section 6.5. Some events did not cause any damage, but several others distorted the internals of the steam generator, especially the feedrings, and damaged the piping supports. Few steam generator water hammer events caused cracking in the feedwater piping.

In the older Westinghouse and Combustion Engineering plants with top-feed steam generators, the water level is normally well above the feedring. Under certain plant transients, such as a main feedwater pump trip, the feedwater flow decreases rapidly, and the water level in the steam generator may drop below the feedring and the feedring will be uncovered. It takes about 1 to 2 minutes to drain the feedring if it is designed with bottomdischarge holes shown in Figure 41, which was a typical design for the original feedrings in the older plants. The draining of a feedring can lead to a water hammer as explained in Section 6.5.1. Malfunction of check valves has also played a major role in some water hammer events.

The steam generator water hammer problems were not expected in some newer Westinghouse and Combustion Engineering plants with preheat steam generators because, as discussed in Section 2.2.1, a forward flushing practice is followed at the startup of the plant. In addition, the design changes identified for preventing water hammer in older top-feed steam generators were incorporated in preheat steam generators. However, a steam generator water hammer did occur in the auxiliary 
feedwater line of a preheat steam generator at a non-U.S.PWR, possibly because of multiple check valve failures.

Steam generator water hammer problems are not expected with the B\&W once-through steam generator design because it has separate main and auxiliary feedwater headers located external to the steam generator shell as shown in Figure 7. The feedwater from the headers is introduced in the steam generator through several risers which function like J-tubes and keep the headers full of water (Han and Anderson 1982, Serkiz 1983).

Several design modifications and operational procedure changes were implemented to prevent or mitigate water hammer in the top-feed steam generators. The most effective method for preventing water hammer is to keep the feedring and piping filled with water so that steam does not enter into them. This is generally accomplished by plugging the bottom discharge holes shown in Figure 41 and installing J-tubes on the top of the feedring as shown in Figure 5. The J-tubes prevent rapid draining, but do not stop it. A slow leakage of the feedwater takes place through the annular gap between the thermal sleeve and the feedwater nozzle and through the closed feedwater valve. In addition, evaporation of feedwater also takes places. As a result of these leaks and the evaporation, it takes about 20 minutes or more to drain feedrings with J-tubes. Therefore, installation of Jtubes is effective only if the feedwater flow is reestablished before a significant amount of steam enters the feedring and piping. However, the resumed feedwater flow rate should be limited so that a water slug does not form. The explanation of the water hammer phenomenon presented in Section 6.5.1 indicates that a shorter horizontal feedwater pipe at the feedwater nozzle would reduce the magnitude of the pressure pulse resulting from a water hammer. These design and operation modifications are summarized as follows:

- Plug the holes in the bottom-discharge feedring and install J-tubes on the top of the feedring,
- Reduce the length of the horizontal run of pipe to less than $2.44 \mathrm{~m}(8 \mathrm{ft})$ at the steam generator inlet nozzle, and

- Promptly resume feedwater flow into the steam generator to minimize the amount of steam that enters the feedring and piping. However, limit the feedwater flow rate to about $570 \mathrm{l} / \mathrm{min}$ (150 gpm) per steam generator so that a slug of cold water does not form.

Design guidelines and preoperational test requirements for preventing water hammers and minimizing the consequences of water hammers in top-feed steam generators were incorporated into Section 10.4.7 of the Standard Review Plan in 1975. Starting with Trojan, all licensed Westinghouse and Combustion Engineering plants equipped with top-feed steam generators have Jtubes installed on the top of the feedring as shown in Figures 5 and 14, and have short horizontal runs of inlet piping. The plant operators have performed a test to confirm the adequacy of plant operating procedures to avoid damaging water hammers (USNRC 1979c). In addition, several operating plants have made specific modifications in the hardware or procedures. For example, some plants installed a separate nozzle to inject cold auxiliary feedwater into the steam generator when the main feedwater line is isolated. In this case, the cold auxiliary feedwater will not enter a steamfilled feedring during steam generator refilling. In some newer steam generators, such as the Delta 75 model designed by Westinghouse, the thermal sleeve is welded to the feedwater pipe to stop the leakage through the gap between the thermal sleeve and the feedwater nozzle in the event the feedring is uncovered. The thermal sleeve is also welded to the feedwater nozzle in the steam generators designed by Siemens/KWU.

Other approaches used at the design stage to reduce the impact of potential steam generator water hammer include: (a) use of vents such as the one shown in Figure 14, (b) inspection of check valves, and (c) installation of redundant check valves on feedwater piping. Other preventative 
measures include increased operator awareness and training, and utilization of surveillance equipment such as temperature sensors to detect voids in systems with a history of steam generator water hammer events (Serkiz 1983). 


\section{FINDINGS}

The main objective of the study reported here was to evaluate the effectiveness of industry efforts for managing thermal fatigue, flow-accelerated corrosion, and water hammer damage that has occurred in the feedwater piping. This includes an evaluation of design modifications, operational procedure changes, augmented inspection programs, and repair and replacement activities. Four specific actions were taken to accomplish the objective: (a) review of field experience to identify trends of operating events, (b) review of related technical literature, (c) visits to three PWR plants and a $P W R$ vendor, and (d) solicitation of information from eight other countries.

Our assessment of field experience related to PWR feedwater nozzle cracking is that the USNRC licensees have apparently taken sufficient action to minimize the feedwater nozzle cracking caused by thermal fatigue. As a result of the examinations conducted in response to Bulletin 79-13, feedwater nozzle fatigue cracking was detected in 18 PWRs during 1979 to 1983 . Then, there was about one fatigue cracking event per year from 1983 to the bulletin closure in 1991. The frequency of feedwater nozzle cracking events increased to six per year during 1992 and 1993. But since then through 1996, we have not identified any additional feedwater nozzle cracking event.

Our assessment of field experience related to flowaccelerated corrosion damage shows four components in the portion of the feedwater piping within the scope of this report that have experienced significant wall thinning: carbon steel J-tubes, feedrings, and thermal sleeves in the top-feed steam generators, and auxiliary feedwater lines in the preheat steam generators. The USNRC licensees have taken sufficient action to minimize the wall thinning in J-tubes and auxiliary feedwater lines. However, we did not find specific industry actions to minimize the wall thinning in feedrings and thermal sleeves, but we found visual inspection being performed and repair when needed.
Our assessment of field experience related to steam generator water hammer damage indicates that the USNRC licensees have taken sufficient actions to minimize water hammer in both top-feed and preheat steam generators. However, we have not evaluated the industry efforts to minimize the multiple check valve failures that have played a major role in several steam generator water hammer events.

\subsection{Major Findings}

- The characteristics of the damage caused by thermal fatigue are different than those caused by flow-accelerated corrosion. Thermal fatigue cracking generally occurs in a relatively local, safety-related portion of the feedwater piping inside the containment, whereas wall-thinning caused by flowaccelerated corrosion typically occurs, with few exceptions, in the non-safety related balance-of-plant piping outside the containment.

- A through-wall crack caused by thermal fatigue will generally leak long before the component ruptures. However, in the unlikely event of a large overload, a pipe with fatigue cracks might fail catastrophically without any prior leakage. A component damaged by flowaccelerated corrosion loses its strength and can fail under normal operating pressure; a large fitting or pipe might fail catastrophically without any warning.

- Sites susceptible to thermal fatigue cracking are found in those portions of the feedwater piping and nozzles where stratified flows and coolant leakage, respectively, are present; these locations are generally well identified. Sites susceptible to flow-accelerated corrosion are found throughout the feedwater system and are difficult to identify without predictive analysis because several factors are involved. 
- The factors causing thermal fatigue and flowaccelerated corrosion damage are well understood. Advanced ultrasonic examination techniques can be used to reliably characterize thermal fatigue cracks. Cost-effective radiographic techniques for estimating wall thickness are being developed as a means to assess flow-accelerated corrosion damage.

- Several effective techniques have been developed for monitoring, mitigating, and repairing the damage caused by thermal fatigue and flow-accelerated corrosion.

The above findings indicate that appropriate analysis, inspection, monitoring, mitigation, and replacement techniques have been developed for managing thermal fatigue and flow-accelerated corrosion damage to feedwater nozzles, piping, and feedrings. Adequate training and appropriate applications of these techniques can ensure effective management of the damage. Several PWR plant operators have been proactive in managing this type of damage.

The major findings are supported by the following specific findings, which are grouped in three categories: (a) damage caused by degradation mechanisms, (b) inservice inspection methods for characterizing the damage, and (c) techniques used to mitigate and repair the damage.

\subsection{Specific Findings - Degradation Mechanisms}

Effective management of aging damage requires that the degradation mechanisms causing damage be well understood. The nuclear industry has accumulated considerable plant experience, performed flow stratification and flow-accelerated corrosion tests to determine the factors affecting the damage, and developed tools to predict the flow-accelerated corrosion. The plant operating experience and our review of the related literature indicate these mechanisms are adequately understood. Our specific findings for thermal fatigue and flow-accelerated corrosion of PWR feedwater piping are as follow.

\subsubsection{Thermal Fatigue}

- Thermal fatigue cracking of the main feedwater piping has not occurred at plants where the auxiliary feedwater is directly introduced into the steam generator shell and not into the main feedwater line. Such plants include Babcock \& Wilcox PWRs with oncethrough steam generators and Westinghouse and Combustion Engineering PWRs with recirculating steam generators equipped with preheaters.

- Use of cold auxiliary feedwater with cyclic on/off flow control is mainly responsible for the flow stratification which causes thermal fatigue damage.

- The major fatigue cracking is caused by local thermal stratification. Factors which cause high stresses during thermal stratification are the temperature difference between the hot steam generator coolant and cold auxiliary feedwater and the geometric discontinuities on the inside surface of the feedwater piping. Major cracks have generally been found at geometric discontinuities (such as counterbores and welds) where large, throughwall stresses develop and cause crack growth.

- The stress distribution resulting from local thermal stratification is complex because of the short length of the piping exposed to the stratified flow, the feedwater nozzle and elbow end constraint effects, and the geometric discontinuities at the inside surface of the feedwater piping.

- The temperature distribution in a pipe wall is plant specific, because in addition to the hot and cold coolant temperatures and flow rates, it depends on piping layout. Therefore, the results from laboratory tests or from other plants may not be directly applicable to a given plant. 
- Thermal striping takes place in a stratified fluid when large relative velocities between hot and cold coolants are present. Stresses produced by thermal striping can initiate cracks on the inside surface but do not cause through-wall crack propagation because through-thickness stresses attenuate rapidly.

- It appears from the available data, that the recent fatigue cracking of feedwater piping is limited to U.S. PWRs. Information obtained from foreign countries does not mention any recent fatigue cracking events.

- Bypass leakage through the gap between the thermal sleeve and feedwater nozzle has caused fatigue cracking in the nozzle bore, nozzle inside radius, and steam generator shell regions. At least two main feedwater nozzles and one auxiliary feedwater nozzle have experienced such cracking.

- Thermal cycling could cause cracking in the auxiliary feedwater piping where it connects to the main feedwater line. However, such cracking has not been reported.

\subsubsection{Flow-Accelerated Corrosion}

- Flow-accelerated corrosion is widespread; it has been reported at both U.S. and foreign PWRs.

- The main factors affecting feedwater piping flow-accelerated corrosion are fluid temperature, bulk and local flow velocities, material composition, and water chemistry. These factors may vary along the feedwater piping and, therefore, play important roles in making some locations more susceptible to flowaccelerated corrosion than other locations.

- The maximum corrosion rate for most feedwater piping conditions occurs at about $150^{\circ} \mathrm{C}\left(300^{\circ} \mathrm{F}\right)$.
- Piping configuration (elbow, tee, nozzle, orifice, etc.) and piping inside surface irregularities determine the local velocities of the feedwater. Inside surface irregularities are developed during the fabrication process or caused by design related features such as weld discontinuities and surface damage caused by fatigue cracks or cavitation pitting. The piping configuration has a primary effect on the local flow velocities of the feedwater, whereas the surface irregularities have a secondary effect.

- Components in carbon steel (SA-106 GrB) feedwater piping containing a very small amount of chromium (less than $0.1 \mathrm{wt} \%$ ) and exposed to high local velocity fluids are more susceptible to flow-accelerated corrosion.

- The coolant chemistry (dissolved oxygen and $\mathrm{pH}$ level) also affects the flow-accelerated corrosion rates. A lower dissolved oxygen content and $\mathrm{pH}$ level are associated with higher corrosion rates. Even though the cold $\mathrm{pH}$ level is the same for the entire feedwater system, the hot $\mathrm{pH}$ level varies throughout the system. As a result, the susceptibility to flow-accelerated corrosion also varies throughout the system.

- Use of optimum water chemistry reduces wall thinning rates but does not eliminate them; some research results show that the maximum rates are still about 0.1 to 0.2 $\mathrm{mm} / \mathrm{yr}(0.004$ to $0.008 \mathrm{in} . / \mathrm{yr})$, even when the water chemistry is optimum.

- Several uncertainties are present when estimating flow-accelerated corrosion rates. These uncertainties are associated with the original piping component thickness, the exact amounts of the trace alloys present in the material, the actual number of operating hours, the plant chemistry history, and the presence of discontinuities on the inside surface of the piping. 
- Flow-accelerated corrosion has caused wall thinning of steam generator feedrings and distribution boxes. Many utilities have modeled these components in CHECWORKS to determine their susceptibility to such damage.

- It is not known whether thinning of thermal sleeves is a widespread phenomenon. It appears that flow-accelerated corrosion could have caused this thinning. Monitoring of nozzle wall temperature can detect leakage taking place because of thinning.

- Flow-accelerated corrosion generally does not cause wall thinning in auxiliary feedwater lines because the coolant in these lines is stagnant during power operations and it is cold when it is flowing. One exception is PWRs with preheat steam generators where a small portion of the main feedwater is diverted through the auxiliary feedwater lines during normal operation. A portion of these lines exposed to hot main feedwater flowing at high velocities have experienced significant wall thinning.

- Valve leakage has also caused flowaccelerated corrosion damage in piping containing stagnant fluid.

\subsection{Specific Findings - Inservice Inspections}

\subsubsection{Characterization of Fatigue Cracks}

- Conventional ultrasonic examinations are reliable in detecting thermal fatigue cracks in carbon steel feedwater piping, but have a very poor sizing capability.

- Ultrasonic examinations conducted using the minimum ASME Code requirements are reliable for estimating the length of a fatigue crack, but not the through-wall extent of the crack.
- Advanced ultrasonic techniques such as tipdiffraction techniques can reliably size crack depths.

- Discrimination of reflectors, such as geometry effects, inclusions, and crack tips, is essential for reliable detection and accurate sizing of fatigue cracks. Use of more than one inspection technique provides more reliable sizing of cracks.

- Radiographic examinations are not adequate for detecting tight fatigue cracks but can detect cracks that are open and filled with corrosion products.

- Field experience shows that counterbores at the feedwater nozzle-to-pipe welds have experienced thermal fatigue cracking. The cracking locations have often been outside the ASME Code examination volume and, therefore, not inspected during ISI.

- The phased array technique can be used for inspection of the feedwater nozzle inner radius region. This technique has been used at several BWR plants to inspect the feedwater nozzle inner radius region, which is also susceptible to fatigue damage, and its performance has been demonstrated with nozzle mockups.

\subsubsection{Characterization of Wall Thinning}

- Use of conventional radiographic testing for thickness measurements is limited to smalldiameter piping; inspection of large-diameter piping requires longer exposure times resulting in higher costs and increased personnel exposure. The main advantage of $\mathrm{RT}$ is that it does not require removal of the insulation.

- Use of filmless radiography with phosphor plates is being evaluated in the field. This technique is expected to dramatically reduce the exposure dose and significantly reduce inspection time and personnel safety concerns associated with performing RT within a plant. 
- Manual UT is the most commonly used inspection method for the detection and trending of wall thickness changes because of its accuracy and relatively low cost. A properly conducted UT examination can estimate the pipe wall thickness within $5 \%$ of the actual value. Industry practice is to overlay a grid on the pipe wall and then spot measure the thickness at each grid location.

- Field experience has found that use of automated UT for thickness measurements is too cumbersome and time consuming.

- Computed tomography, an advanced radiographic examination technology, can be used to characterize wall-thinning damage in piping and thermal sleeves. However, this technology is slow and expensive, and the equipment is too large for use in the field.

- The computer code CHECWORKS (or its earlier versions) is used by all U.S. PWR utilities for estimating flow-accelerated corrosion rates and identifying inservice inspection locations in feedwater piping. Utilities perform inspections at additional locations based on industry experience and because of the uncertainties associated with several input parameters to the code.

\subsection{Specific Findings - Mitigation, Monitoring, Repair, and Replacement}

- Use of continuous auxiliary feedwater flow rather than intermittent flow significantly reduces the thermal fatigue damage to the feedwater piping. Several utilities have implemented continuous auxiliary feedwater flow by making modifications to the feedwater system and changes in the operating procedures.

- Some plants use heated main feedwater during plant startup and hot standby conditions to mitigate thermal fatigue damage in the feedwater nozzle region.
- Several plants have redesigned the feedwater nozzle counterbores to eliminate the stress raisers and installed thermal liners to protect the counterbores and other susceptible sites from thermal fatigue damage. One plant has modified the feedwater piping layout to introduce the auxiliary feedwater directly into the steam generators instead of into the main feedwater lines. (These steam generators originally had auxiliary feedwater nozzles that were not used.)

- In one plant, the feedwater nozzle-to-piping connection has been redesigned to protect the leading edge of the thermal sleeve from flowaccelerated corrosion. This design also prevents feedwater leakage through the gap between the nozzle and the thermal sleeve and, thus, protects the nozzle bore and inner radius region from fatigue damage. Use of a thermal liner also provides similar protection to the thermal sleeve and feedwater nozzle.

- Use of a fatigue monitoring system can assist in detecting the presence of thermal stratification and in predicting temperature distributions and flow rates so that the fatigue usage and crack growth rates can be estimated more accurately.

- Low-alloy steels such as $1 \frac{1}{4} \mathrm{Cr}-1 / 2 \mathrm{Mo}$ steel (SA335, Grade P11) and 21/4Cr-1Mo steel (SA335, Grade P22), austenitic stainless steel, and Alloy 600 provide protection against flowaccelerated corrosion.

- Ammonia may be used for the $\mathrm{pH}$ control in the feedwater systems with no copper alloy materials and no condensate polishers present; however, the cold $\mathrm{pH}$ should be increased, at least up to 9.7, to avoid flow-accelerated corrosion damage.

- Morpholine is widely used in the feedwater systems with copper alloy materials in the water heaters and condensers to maintain the cold $\mathrm{pH}$ in the range of 8.8 to 9.2 , provided the condensate polishers are absent. Ethanolamine instead of morpholine may be used when condensate polishers are present. 
- Nuclear industry experience indicates that the corrosion products transport with ethanolamine is lower than that with ammonia and even lower than that with morpholine.

- Several piping design modifications and operational procedure changes made to the feedwater system appear to be adequate for preventing water hammer in top-feed steam generators; no water hammer events have been reported recently.
- The most effective method for preventing water hammer is to keep the feedring and piping filled with water so that steam does not enter into them. Therefore, the thermal sleeve in several newer or replacement steam generators is welded to the feedwater piping to stop leakage through the gap between the thermal sleeve and the feedwater nozzle, in the event the feedring is uncovered. This change also protects the thermal sleeve from flowaccelerated corrosion damage and the feedwater nozzle bore and inside radius section from thermal fatigue damage. 


\section{REFERENCES}

Aguiar, D. J., 1993. Failure Investigation of Diablo Canyon Power Plant Unit \#1 Feedwater Nozzle Piping Adjacent to Steam Generators 1-1 and 1-3, Report 420DC-93.19, Pacific Gas \& Electric.

ASME 1995a. Risk-Based Alternative Selection Process for Inservice Inspection of LWR Nuclear Power Plant Components, ASME Research Task Force on Risk-Based Inspection Guidelines - LWR Nuclear Power Plant Application, November.

ASME 1995b. Section LX - Qualification Standard for Welding and Brazing Procedures, Welders, Brazers, and Welding and Brazing Operators, ASME Boiler and Pressure Vessel Committee, Subcommittee on Welding, pp. 65-89.

ASME 1990. "Case N-480: Examination Requirements for Pipe Wall Thinning Due to Single Phase Erosion Corrosion," Cases of ASME Boiler and Pressure Vessel Code, Section XI, Division 1, American Society of Mechanical Engineers, New York.

Bain, R. A., S. O. Collins, and M. F. Testa 1992. "New Insights into Thermal Stratification of Feedwater Piping in PWR Plants," PVP-Vol. 235, American Society of Mechanical Engineers, pp. 113-118.

Balkey, K. R., 1995. "Recent Industry, Regulatory and ASME Developments," American Society of Mechanical Engineers Research Task Force on Risk-Based Inspection, San Francisco, California, November 28.

Bamford, W. H., A. Thurman, and M. Mahlab 1981. "Fatigue Crack Growth in Pressurized Water Reactor Feedwater Lines," American Society of Mechanical Engineers 8I-PVP-2.

Bamford, W. H., et al. 1987. "Integrity Issues in PWR Steam Generators and Feedwater Systems," American Society of Mechanical Engineers PVP-Vol. 119, pp. 19-30.

Bamford, W. H., G. V. Rao, and J. L. Houtman 1992. "Investigation of Service-Induced Degradation of Steam Generator Shell Materials," Proceedings of the Fifth International Symposium on Environmental Degradation of Materials in Nuclear Power Systems - Water Reactors, August 25-29, 1991, Monterey, California, pp. 588-595.

Becker, F. L., et al. 1992. "Performance Demonstration Test Blocks to Meet the Requirements of the ASME Code," Proceedings of the 11th International Conference on NDE in the Nuclear and Pressure Vessel Industries, April 1992, Albuquerque, New Mexico, ASM International, pp. 213-218.

Bisbee, L. H., 1994. "Enhanced Ultrasonic Examination of Feedwater Pipe-to-Nozzle Welds," Nuclear Plant Journal, March-April, pp. 42-53.

Block, J. A., et al. 1976. Evaluation of PWR Steam Generator Water Hammer, NUREG-0291, U.S. Nuclear Regulatory Commission.

Bosnak, R. J., 1987. "Meeting Minutes of 1/15/87 Technical Panel Discussion of Surry-2 Pipe Failure Implications," Memorandum to T. P. Speis, January 15, 1982, U.S. Nuclear Regulatory Commission. 


\section{REFERENCES}

Bouchacourt, M., et al. 1994. "The BRT-Cicero Code, An Exhaustive Approach to Predicting Flow Accelerated Corrosion," Proceedings of the International Symposium on Contribution of Materials Investigation to the Resolution of Problems encountered in Pressurized Water Reactors (Fontevraud III), 1986, Volume 2, Royal Abbey of Fontevraud, France, pp. 761-768.

Braschel, R., M. Miksch, and G. Schücktanz 1984. "Thermal Stratification in Steam Generator Feedwater Lines," Journal of Pressure Vessel Technology, Vol. 106, February, pp. 78-85.

Bray, D. E., and R. K. Stanley 1989. Nondestructive Evaluation - A Tool for Design, Manufacturing, and Service, McGraw-Hill, New York, pp. 98-99.

Bressler, M. N., 1994. An Integrated Approach to Address Engineering of Operating Nuclear Power Plants, Part I, Codes \& Standards, PVP-16, notes from tutorial presented at the 1994 ASME Pressure Vessels and Piping Conference, Minneapolis, Minnesota, June 1994.

Brook, M. V., 1986. "Ultrasonic Transducers Design for Detection and Characterization of Cracks in Nuclear Primary Pressure Piping," Proceedings of the 8th International Conference on NDE in the Nuclear Industry, 17-20 November 1986, Kissimmee, Florida, American Society for Metals, Materials Park, Ohio, pp. 439-445.

Bush, S. H., 1980. "Nondestructive Examination and Component Reliability - What Should We Be Looking For," Presented at the Third International Conference on NDE, Salt Lake City.

Chexal, B., et al. 1996. Flow-Accelerated Corrosion in Power Plants, EPRI TR-106611, Electric Power Research Institute, Palo Alto.

Chexal, V. K., and J. S. Horowitz 1995. "Chexal-Horowitz Flow-Accelerated Corrosion Model -Parameters and Influences," Current Perspectives of International Pressure Vessels and Piping Codes and Standards, PVP-Vol. B, pp. 231-243. American Society of Mechanical Engineers, New York.

Chexal, V. K., and R. L. Jones 1988. "Implications of the Surry Piping Failure for Other Nuclear and Fossil Units," International Journal of Pressure Vessels \& Piping, 34, pp. 331-343.

Cockfield, D. W. (Portland General Electric), 1988. Letter to USNRC, April 27.

Cofie, N. G., et al. 1994. "Management of Steam Generator Feedwater Nozzle Cracking in PWRs," American Society of Mechanical Engineers, PVP Volume 286, pp. 31-43.

Coley, J. L., 1992. "Inspection reports 50-327/92-09 and 50-328/92-09, Sequoyah 1 and 2," U.S. Nuclear Regulatory Commission, Region II.

Consolidated Edison 1991. Indian Point Unit 21991 Steam Generator Inspection, Evaluation and Repair Activities, Consolidated Edison Company, New York, NY, pp. 8-1 to 8-11.

Consumers Power 1979. "Meeting with NRC on October 25, 1979 - Feedwater Pipe Cracking Problem," Consumers Power Company, Michigan. 
Cowfer, C. D., 1989. "Basis/Background for ASME Code Section XI Proposed Appendix VII: Ultrasonic Examination Performance Demonstration," Nondestructive Evaluation Planning and Application, $R$. D. Streit (ed.), Presented at The Pressure Vessels and Piping Conference, Honolulu, Hawaii, July 2327, 1989, NDE-Vol. 5, American Society of Mechanical Engineers, New York.

Czajkowski, C. J., 1987. Metallurgical Evaluation of an 18-inch Feedwater Line Failure at the Surry Unit 2 Power Station, NUREG/CR-4868, BNL-NUREG-52057.

Davis, J. M., 1991. "ID Creeping Wave Techniques for Detection, Characterization, and Sizing of Planar Flaws," NDE: Applications, Advanced Methods, And Codes and Standards, PVP-Vol. 216/NDE-Vol. 9, American Society of Mechanical Engineers, New York.

Deardorff, A. F., et al. 1990. "Development of a Thermal Striping Spectrum for Use in Evaluating Pressurizer Surge Line Fatigue," Advances in Dynamics of Piping and Structural components, PVP- Vol. 198, American Society of Mechanical Engineering, New York, pp. 23-28.

Delp, G. A., et al. 1985. "Erosion/Corrosion in Nuclear Plant Steam Piping: Causes and Inspection Program Guidelines, " EPRI NP-3944, Electric Power Research Institute, Palo Alto.

Diablo Canyon FSAR. “Accident Analysis,” Chapter 15, DCPP Units 1 \& 2 FSAR Update.

Doctor, S. R., et al. 1995. Development and Validation of a Real-Time SAFT-UT System for the Inspection of Light Water Reactor Components, NUREG/CR-4583 (draft), PNL-5822, Vol. 4, February.

Doctor, S. R., 1984. "NDE Reliability Assessment," Non-Destructive Examination of Pressurized Components, Proceedings of the Third International Seminar on Non-Destructive Examination in Relation to Structural Integrity, Monterey, California, USA, 30-31 August, 1983, Elsevier, pp. 323335.

Duke Power 1979. “Oconee Nuclear Station, Docket Nos. 50-269, -270, -287, Information Requested on PWR Feedwater Lines," letter from W. O. Parker, Jr. (Duke Power) to H. R. Denton (U.S. Nuclear Regulatory Commission), docket Nos. 50-269, 270-287, July 27.

Duquesne Light 1993. "Design Stress for the Auxiliary Feedwater System Exceeded due to Water Hammer," Licensee Event Report 93-01, Beaver Valley Unit 2.

Edelmann, X., and M. Gribi 1990. "Mechanized wall thickness inspection measures up to its cost," Nuclear Engineering International, pp. 54-55.

EPRI 1983. UT Operator Training for Intergranular Stress Corrosion Cracking (IGSCC), Competency Area 910.

Fay, C. W., 1987. Response to IE Bulletin 87-01, Point Beach Nuclear Plant, Units 1 and 2, September 10.

Finn, S., 1989. Nuclear Power Plant System Sourcebook - Zion $1 \&$ 2, SAIC 89/1532, prepared for U.S. Nuclear Regulatory Commission. 
Fischer, E., et al. 1992. "A New Approach for the Inservice Inspection of BWR Reactor Pressure Vessels," Proceedings of the 11th International Conference on NDE in the Nuclear and Pressure Vessel Industries, Albuquerque, New Mexico, USA, April 30 - May 2, ASM International, pp. 87-91.

Florida Power \& Light. St. Lucie Final Safety Analysis Report, Docket 50-389.

Florida Power \& Light 1984. "Steam Generators Feedwater Nozzles Cracking," Licensee Event Report 84005, Turkey Point Unit 4.

Foley, W. J., R. S. Dean, and A. Hennick 1991. Closeout of IE Bulletin 79-13: Cracking in Feedwater System Piping, NUREG/CR-5285, PARAMETER IE-176.

Garrity, J. H. (Maine Yankee Atomic Power Company), 1983. Letter to the U.S. Nuclear Regulatory Commission, "Main Feedwater System," February 17.

Gerber, T. L., et al. 1989. "Acceptance Criteria for Structural Evaluation of Erosion/Corrosion Thinning in Carbon Steel Piping," Transactions of the 10th International Conference on Structural Mechanics in Reactor Technology, Anaheim, California, 1989, Association for Structural Mechanics in Reactor Technology, Los Angeles, Vol. D, pp. 93-101.

Goldberg, A., R. D. Streit, and R. G. Scott 1980. Evaluation of Cracking in Feedwater Piping Adjacent to the Steam Generators in Nine Pressurized Water Reactor Plants, NUREG/CR-1603, UCRL-53000.

Gordon, B. M., et al. 1987. "Service Experience of BWR Pressure Vessels," Performance and Evaluation of Light Water Reactor Pressure Vessels, PVP-Vol. 119, American Society of Mechanical Engineers, New York, pp. 9-17.

Hafner, W., and J. H. Spurk 1990. "Formation of Waves in Thermal Stratified Flow," presented at the International Conference on Physical Modeling of Transport and Dispersion, MIT, Cambridge, Massachusetts, August 7-10, 1990.

Han, J. T., and N. Anderson 1982. Prevention and Mitigation of Steam Generator Water Hammer Events in PWR Plants, NUREG-0918.

Harrington, T. P., 1988. Adaptation of the PARIS Technology for Measuring Wall Thinning in Ferritic Steel Components, EPRI NP-5961, Electric Power Research Institute, Palo Alto.

Higuchi, M., and K. Iida 1992. "Fatigue Strength Data of LWR Structural Materials in Japan (Effects of LWR Water Environment on Fatigue Strength)," Technical Information from Workshop on Cyclic Life on Environmental Effects in Nuclear Applications, PVRC Volume 2, Clearwater Beach, Florida, January 20-21, 1992, Welding Research Council, Inc., New York.

Hoemann, C. S., and E. G. Berak 1989. "Engineering Evaluation of Erosion/Corrosion in Piping Systems" Transactions of the 10th International Conference on Structural Mechanics in Reactor Technology, Anaheim, California, Vol. D, American Association for Structural Mechanics in Reactor Technology, Los Angeles, pp. 117-122. 
Hu, M. H., J. L. Houtman, and D. H. White 1981. "Flow Model Test for the Investigation of Feedwater Line Cracking for PWR Steam Generators," American Society of Mechanical Engineers paper 81-4, American Society of Mechanical Engineers, New York.

Iida, K., et al. 1988. "Abstract of DBA Committee Report, 1988-Survey of Fatigue Strength Data of Nuclear Structural Materials in Japan," unpublished article sent to V. N. Shah (K. Iida is Professor Emeritus, University of Tokyo, Tokyo).

Izenson, M. G., P. H. Rothe, G. B. Wallis 1988. Diagnosis of Condensation-Induced Waterhammer, NUREG/CR-5220, Creare TM-1189, Vol. 1, pp. 48-49.

Jonas, O,, 1988. Erosion-Corrosion of PWR Feedwater Piping-Survey of Experience, Design, Water Chemistry, and Materials, NUREG/CR-5149, ANL-88-23.

Kim, J. H., et al. 1993. "Thermal Stratification and Reactor Piping Integrity," Nuclear Engineering and Design, 139, pp. 83-95.

Lawson, L., 1995. "Compton X-Ray Backscatter Depth Profilometry for Aircraft Corrosion Inspection," Materials Evaluation, November, pp. 936-941.

Lee, H., and E. S. Kenney 1992. "A New Pipe Wall Thinning Inspection System," Nuclear Technology, October, pp. 70-78.

Maeda, N., and G. Yagawa 1991. "Some experiences and development in Japan related to nondestructive examination and fracture mechanics in structural integrity assessment of nuclear power plant components," Nuclear Engineering and Design, 131, May, pp. 329-336.

Martin, J. H., et al. 1990. Safety Engineering Root Cause Report, Root Cause Report 90-001, Southern California Edison.

Martin, J., 1993. "ANO-2 Shutdown Cooling Line Stratification," presented at the EPRI Workshop on Thermal Stratification, Cycling, and Striping (TASCS) Evaluation, June 17-18, 1993, Orlando, Florida, Electric Power Research Institute, Palo Alto.

McBrearty, R. A., 1993. "Report of June 21-25, 1993, Inspection at Haddam Neck, Report No. 93-11," U.S. Nuclear Regulatory Commission Region I.

Mattu, R. K., et al. 1988. Utility Response to NRC Bulletin 87-01, Thinning of Pipe Walls in Nuclear Power Plants, EPRI NP-6066, Electric Power Research Institute, Palo Alto.

Metals Handbook 1989. "Nondestructive Evaluation and Quality Control". Metals Handbook, Ninth Edition, Volume 17, American Society for Metals International, Materials Paris, Ohio.

Miksch, M., et al. 1985. "Loading Conditions in Horizontal Feedwater Pipes of LWRs Influenced by Thermal Shock and Thermal Stratification Effects," Nuclear Engineering and Design, 84, pp.179-187. 


\section{REFERENCES}

Miyoshi, S., H. Fukui, A. Uehara, and M. Yoshida 1992. "Development of the X-Ray CT Scanner for the Piping in Nuclear Power Stations", Proceedings of the 11th International Conference on NDE in the Nuclear and Pressure Vessel Industries, Albuquerque, New Mexico, April 30-May 2, American Society for Metals International, Materials Park, Ohio, pp. 263-265.

Mostafa, S., and M. B. Ramsey. 1994. Unit 3 Steam Generator Feedwater Nozzle Pipe Cracking, San Onofre Unit 3, RCE 93-024, Southern California Edison.

Muscara, J., 1990. "NDE Reliability: A Major Element in the Defence-in-Depth Concept," Proceedings of the 10th International Conference on NDE in the Nuclear and Pressure Vessel Industries, Glasgow, Scotland, 11-14 June, 1990, ASM International, pp. 17-23.

NEA (Nuclear Energy Agency) 1990. Feedwater Pipe Rupture at Loviisa 1 Nuclear Power Plant Unit 1, NEA \#1102.02, Organization of European Community Development (OECD).

NEA (Nuclear Energy Agency) 1993. Feedwater Pipe Rupture at Loviisa 2 Nuclear Power Plant Unit, NEA \#1352.02, Organization of European Community Development (OECD).

NEI 1989. "How Stainless Steel Coating Combats Erosion/Corrosion in Wet Steam," Nuclear Engineering International, May, pp. 16-18.

Nordmann, F., and Fiquet, J. 1996. "Selection Criteria for the Best Secondary Water Chemistry," Nuclear Engineering and Design, pp. 193-201.

Pers-Anderson, E., 1993. "PWR Vessel Head Penetration Inspections," Assuring Structural Integrity of Steel Reactor Pressure Boundary Components, 12th SMiRT-Post conference Seminar No. 2, Paris France, 23-25 August, 1993.

Peterson, S. R., 1992. Summary of October 20, 1992, Public Meeting to Discuss Steam Generator Feedwater Nozzle Cracking, U.S. Nuclear Regulatory Commission, November 23, 1992.

PG\&E 1992. Indications on the Main Feedwater Piping Near the Steam Generator Feedwater Nozzles Due to Thermal Fatigue, Licensee Event Report 92-022-01, Diablo Canyon Unit 1.

PISC-II 1985. A summary of the Program for the Inspection of Steel Components-II (PISC-II) project, PISC II Report No. 1, June.

PSE\&G 1992. "Steam Generator Feedwater Piping Linear Indications," Licensee Event Report 92-014-00, Salem Generating Station, Unit 1.

Rathgeb, W., et al. 1992. "Recent Applications of UT Phased Array Techniques for Inservice Inspection of Primary Components," Proceedings of the 11th International Conference on NDE in the Nuclear and Pressure Vessel Industries, Albuquerque, New Mexico, USA, April 30 - May 2, ASM International, pp. 317-321.

Remy, F. N., and M. Bouchacourt 1992. "Flow-Assisted Corrosion: A Method to Avoid Damage," Nuclear Engineering and Design, 133, pp. 23-30. 
Richardson, J. E., 1992. "Summary of the Erosion/Corrosion Audits: Related Events and Proposed Future Actions," USNRC Memorandum for W. T. Russell, December 1, 1992.

Roarty, D., 1993. "Overview of TASCS (Thermal Stratification, Cycling, and Striping) Testing Program," presented at the EPRI Workshop on Thermal Stratification, Cycling, and Striping (TASCS) Evaluation, June 17-18, 1993, Orlando, Florida, Electric Power Research Institute, Palo Alto.

Roarty, J. D., 1986. "Corrosion-Erosion of Steam Generator J-Tubes," Proceedings of the International Meeting on Nuclear Power Plant Maintenance, March 23-27, 1986, Salt Lake City, Utah, pp. 7-53 to 7-62, American Nuclear Society, LaGrange Park, Illinois.

Scherer, A. E. (Combustion Engineering), 1981. Letter to Mr. Stello (U.S. Nuclear Regulatory Commission), "Steam Generator Feedring Damage," July 17.

Serkiz, A. W., 1983. Thermal-Hydraulics of Nuclear Reactors, Vol. II, papers presented at The Second International Topical Meeting on Nuclear Reactor Thermal-Hydraulics, Santa Barbara, California, January 11-14, American Nuclear Society, pp. 803-805.

Sexton, D. E., M. Kasahara, and R. A. Uffer 1982. Evaluation of Water Hammer Potential in Preheat Steam Generators, NUREG/CR-3090, December.

Seydal, J., 1982. "Ultrasonic Synthetic-Aperture Focusing Techniques in NDT," Research Techniques in Nondestructive Testing, Volume 1, Sharpe, R. S. (editor), Academic Press, pp. 1-47.

Shack, W. J., and O. Jonas 1988. "Investigation of Erosion-Corrosion in Reactor Piping," presented at the Workshop on Structural Integrity of Reactor Piping Systems, May16-19, Tokyo, Japan, U.S. Nuclear Regulatory Commission and Japanese Ministry of International Trade and Industry.

Shah, V.N., and P. E. MacDonald (editors) 1993. "Aging and Life Extension of Major Light Water Reactor Components," Elsevier Science Publishers, pp.535-539.

Shankar, R., and J. Bridgeman, 1990. "Erosion/Corrosion Data Handling for Reliable NDE", 10th International Conference on NDE in the Nuclear and Pressure Vessel Industries, Glasgow, Scotland, June 11-14, pp. 397-401.

Shvarts, S., et al. 1994. "Development of Methodology for Evaluating and Monitoring Steam Generator Feedwater Nozzle Cracking in PWRs," Plant Systems/Components Aging Management, PVP-Vol. 283, American Society of Mechanical Engineering, New York, pp. 97-109.

Silk, M. G., 1996. "Estimates of the Probability of Detection of Flaws in TOFD Data with Varying Levels of Noise," Insight, Vol. 38, No. 1, January, pp. 31-36.

Slama, G., 1994. "Steam Generator Towards Greater Reliability," Steam Generator and Heat Exchanger Conference Proceedings, Volume 1, Canadian Nuclear Society, Toronto, pp. 1.35-1.45.

Snaider, R., 1980. BWR Feedwater Nozzle and Control Rod Drive Return Line Nozzle Cracking, NUREG0619. 


\section{REFERENCES}

Spanner, J. C., et al. 1992. "Performance Demonstrations for Inservice Inspection of Nuclear Power Plant Components," Proceedings of the 11th International Conference on NDE in the Nuclear and Pressure Vessel Industries, April 1992, Albuquerque, New Mexico, ASM International, pp. 205-212.

Sperber, M., 1988. "Inspection of Surry Feedwater Piping Uncovers New Thinning Problems," Inside NRC, October 10, p. 9.

Stoller (S. M. Stoller Corporation) 1979. "Cracked FW-to-Nozzle Pipe Elbow Welds," Nuclear Power Experience, PWR-2, VI.E.211.

Stoller (S. M. Stoller Corporation) 1983. "Reactor Trip - Water Hammer During SG Level Restoration -FW Pipe Weld Cracks," Nuclear Power Experience, PWR-2, VI.E.435.

Stoller (S. M. Stoller Corporation) 1985. "Heater Drain Pump Discharge Pipe Ruptured, Personnel Burned-FW Pressure Transient During Turbine, Reactor Trips--Pipe Eroded/Corroded," Nuclear Power Experience, PWR-2, III.

Stoller (S. M. Stoller Corporation) 1986. "Addition to VI.E.561 re: Aux FW Pumps Inoperable - Steam Supply Line Hangers Damaged - Water Hammer from Condensed Steam," Nuclear Power Experience, PWR-2, VI.E.627.

Stoller (S. M. Stoller Corporation) 1987. Characterization of the Performance of Major LWR Components, EPRI NP-5001, Electric Power Research Institute, Palo Alto.

Stoller (S. M. Stoller Corporation) 1991. "SG FW Sparger Damage - Metal Debris - Feedring Weld Thermal Stress, Vent Assembly Erosion \& Corrosion - Inadequate Design, "Nuclear Power Experience, PWR2, V.D.551.

Stoller(S. M. Stoller Corporation) 1992a. "IN 92-07 re: Rapid Flow-Induced Erosion/Corrosion of FW Piping - Westinghouse SG Design Deficiency," Nuclear Power Experience, PWR-2, VI.E.1131.

Stoller (S. M. Stoller Corporation) 1992b. "Linear Indications on Weld in SG Piping - Thermal Fatigue Suspected," Nuclear Power Experience, PWR-2, V.D.590.

Su, N. T., 1990. Special Study Report-Review of Thermal Stratification Operating Experience, AEOD/S902, U.S.Nuclear Regulatory Commission, Office of Analysis and Evaluation of Operational Data, March.

Talja, A., and E. Hansjosten 1990. "Results of Thermal Stratification Tests in a Horizontal Pipe Line at the HDR-Facility," Nuclear Engineering and Design, 118, pp. 29-41.

Taylor, J. M., 1995. "Erosion/Corrosion (Flow-Accelerated Corrosion)- Induced Pipe Thinning in U.S. Nuclear Plants - Update on NRC and Industry Activities," USNRC Memorandum for The Commissioners, February 7, 1995, SECY-95-026, U.S. Nuclear Regulatory Commission.

Terrell, J. B., 1988. Fatigue Life Characterization of Smooth and Notched Piping Steel Specimens in $288^{\circ} \mathrm{C}$ Air Environments, NUREG/CR-5013, MEA-2232.

Thailer, H. J., K. J. Dalal, and L. F. Goyette 1995. "Flow-accelerated Corrosion in Steam Generators," presented at the 1995 ASME PVP Conference, Honolulu, Hawaii, June 1995. 
Tremaine, P. R., et al. 1977. "Calculation of Gibbs Free Energies for Ferrous Ions and the Solubility of Magnetite in $\mathrm{H}_{2} \mathrm{O}$ and $\mathrm{D}_{2} \mathrm{O}$ to $300^{\circ} \mathrm{C}$," Thermochim Acta, Netherlands, p. 287.

Turner, J. S., 1973. Buoyancy Effects in Fluids, Cambridge University Press, Cambridge.

Thurman, A. L., M. S. Mahlab, and R. E. Boylstein 1981. "3-D Finite Element Analysis for the Investigation of Feedwater Line Cracking in PWR Steam Generators," 81-PVP-3, American Society of Mechanical Engineers.

TVA 1973. "Mechanical Transition - Feedwater to S. G. Nozzle," Drawing 47B17-4, Revision 1, Sequoyah Nuclear Plant.

TVA 1992a. “Cracking of Feedwater Piping," handout at TVA/NRC Management Meeting, April 3.

TVA 1992b. Feedwater Nozzle Crack, Steam Generator Loop 3, Sequoyah Nuclear Plant, Unit 1, Report Number 92-7334, June 22.

Uffer, R. A., et al. 1982. Evaluation of Water Hammer Events in Light Water Reactor Plants, NUREG/CR2781, QUAD-1-82-018, EGG-2203, pp. 5-1 to 5-3.

Uffer, R., 1987. "Nuclear Plant Water Hammer - Current Status," Paper No. 87-PVP-17, presented at the Pressure Vessel and Piping Conference, San Diego, California, June 28 - July 2, 1987, American Society of Mechanical Engineers, New York.

USNRC, 1979a. Cracking in Feedwater System Piping, IE Bulletin No. 79-13, Revisions 0, 1, 2,

U.S. Nuclear Regulatory Commission.

USNRC 1979b. Letter from V. Stello (NRC) to all PWR licensees, Information requested on PWR Feedwater Piping pursuant to 10 CFR K50.54(f), May 25.

USNRC 1979c. Water Hammer in Nuclear Power Plants, NUREG-0582, U.S. Nuclear Regulatory Commission, Washington, D. C., July.

U'SNRC 1980. USNRC Investigation and Evaluation of Cracking Incidents in Piping in Pressurized Water Reactors, NUREG-0691.

USNRC 1982. "Stress Corrosion Cracking in Thick Wall, Large-Diameter, Stainless Steel Recirculation System Piping at BWR Plants," USNRC Bulletin 82-03, Revision 1.

USNRC 1983a. "Stress Corrosion Cracking in Large-Diameter Stainless Steel Recirculation System Piping at BWR Plants," USNRC Bulletin 83-02.

USNRC 1983b. Inspection Report 50-348/83-08, St. Lucie Unit 1.

USNRC 1984a. “Auxiliary Feedwater Sparger and Pipe Hanger Damage,” USNRC Information Notice 84-32.

USNRC 1984b. Inspection Reports 84-07, 84-10, and 85-22, Joseph M. Farley Unit 1.

USNRC 1985. "Recent Water Hammer Events," USNRC Information Notice 85-76. 


\section{REFERENCES}

USNRC 1986a. "Failure of Main Feedwater Check Valves Causes Loss of Feedwater System Integrity and Water-Hammer Damage," USNRC Information Notice 86-01.

USNRC 1986b. Loss of Power and Water Hammer Event at San Onofre, Unit 1, on November 21, 1985, NUREG-1190, U.S. Nuclear Regulatory Commission.

USNRC 1987a. "Significant Unexpected Erosion of Feedwater Lines," USNRC Information Notice 87-36.

USNRC 1987b. Inspection Report 88-01, Beaver Valley Unit 1.

USNRC 1987c. “Feedwater Line Break,” USNRC Information Notice 86-106, Supplement 1.

USNRC 1987d. “Thinning of Pipe Walls in Nuclear Power Plants,” USNRC Bulletin 87-01.

USNRC 1988a. "Summary of Responses to NRC Bulletin 87-01," USNRC Information Notice 88-17.

USNRC 1988b. “Feedwater Line Break," USNRC Information Notice 86-106, Supplement 2.

USNRC 1988c. NRC Integrated Program for the Resolution of Unresolved Safety Issues A-3, A-4, and A-5 Regarding Steam Generator Tube Integrity, NUREG-0844.

USNRC 1988d. “Thermal Stresses in Piping Connected to Reactor Coolant System," USNRC Bulletin 88-08, Supplement 2.

USNRC 1989. Erosion/Corrosion-Induced Pipe Wall Thinning, USNRC Generic Letter 89-08, May 2.

USNRC 1991a. "High-Energy Piping Failures Caused by Wall Thinning," USNRC Information Notice 91-18.

USNRC 1991b. "Steam Generator Feedwater Distribution Piping Damage," USNRC Information Notice No. 91-19.

USNRC 1991c. “Thermal Stratification in Feedwater System Piping,” USNRC Information Notice No. 91-38.

USNRC 1991d. Erosion of Steam Generator Feed Nozzle Thermal Sleeve Update, Morning Report,-Region IV, March 15, 1991.

USNRC 1992. "Rapid Flow-Induced Erosion/Corrosion of Feedwater Piping," USNRC Information Notice No. 92-07.

USNRC 1993. "Thermal Fatigue Cracking of Feedwater Piping to Steam Generators," USNRC Information Notice 93-20.

Van Duyne, D. A., et al. 1991. "Global Stratification Effects in Feedwater Line to Steam Generator in PWR Power Plant," PVP-Vol. 218, pp. 9-12, American Society of Mechanical Engineers.

Virginia Power 1987. Surry Unit 2 Reactor Trip and Feedwater Pipe Failure Report, Rev. 0. 
Walker, S. M., and E. Martinez, 1994. "Evaluation of New Technology for Detection of Erosion-Corrosion," 12th International Conference on NDE in the Nuclear and Pressure Vessel Industries, Philadelphia, Pennsylvania, October 11-13, pp. 147-150

Westinghouse (Westinghouse Electric Corporation) 1989. Indian Point Unit 2, Steam Generator Girth Weld, Feedwater Nozzles Report, Spring, 1989 Outage, Consolidated Edison of New York, WCAP 12294, Revision 1.

Westinghouse (Westinghouse Electric Corporation) 1990. Indian Point Unit 2, Steam Generator Inspection, Repair, and Restoration Program, WCAP 12574, SG-05-022.

Wilson, J. L. (Tennessee Valley Authority), 1992. Letter to the U.S. Nuclear Regulatory Commission, "Sequoyah Nuclear Plant (SNP) - Request for Relief from the American Society of Mechanical Engineers (ASME), Section XI, Hydrostatic Pressure Test Requirements," March 23.

Wolf, L., et al. 1987. "Results of Thermal Mixing Tests at the HDR-Facility and Comparisons with Best-Estimate and Simple Codes," Nuclear Engineering and Design, 99, pp. 287-304.

Woodward, W. S., 1983. "Fatigue of LMFBR Piping Due to Flow Stratification," Paper 83-PVP-59, American Society of Mechanical Engineers, New York.

Wu, P. C., 1989. Erosion/Corrosion-Induced Pipe Wall Thinning in U.S. Nuclear Power Plants, NUREG1344, April. 
APPENDIX 


\section{APPENDIX}

\section{QUESTIONNAIRE SUBMITTED TO FOREIGN COUNTRIES}

1. What are your current ISI practices/requirements regarding the examination of the feedwater (FW) system? What documents imposed these requirements.

2. Has your utility experienced cracking and/or erosion/corrosion in the feedwater system? If so, provide a brief description of the problem.

3. Provide a brief description of current or past supplemental examinations that have been implemented for the FW system. Considering that some cracking has taken place outside the Code required examination volume, has any effort been made to extend examination volume; has any effort been made to extend examination coverage into the adjacent base metal.

4. Provide a description of the examination techniques that are being used to detect fatigue cracks in the FW system. Have the inspection techniques been qualified for the detection of fatigue? If so, provide a brief description of the qualification process (e.g., flaw types, blind tests, etc.).

5. It has been shown that sizing the through-wall extent of cracks with the amplitude drop technique is unreliable. Describe the standard or supplemental ultrasonic techniques used to size cracks.

6. Describe the methodology used to discriminate geometry from flaw indications. What percentage of the ultrasonic examinations performed on the FW system are performed with automated systems? What system(s) are used?

7. Provide a brief description of the examination techniques used to detect erosion/corrosion. What area of the FW system are examined and how are they selected? Are any enhanced inspection techniques being considered? 


\begin{tabular}{l} 
NRC FORM 325 \\
$\begin{array}{l}\text { (2-89) } \\
\text { NRCM } 1102, \\
3201,3202\end{array}$ \\
$\begin{array}{l}\text { BSE NUCLEAR REGULATORY COMMISSION } \\
\text { (Seo instuctions on the reverse) }\end{array}$ \\
\hline
\end{tabular}

\section{TITLE AND SUBTITLE}

Review of Industry Efforts to Manage Pressurized Water Reactor Feedwater Nozzle,

\section{NUREG/CR-6456 INEL-96/0089}

\section{Piping, and Feodring Cracking and Wall Thinning}

5. AUTHOR(S)

V. N. Shah, A. G. Ware, A. M. Porter

6. TYPE OF REPORT

3. DATE REPORT PUBLISHED

\begin{tabular}{l|l} 
MONTH & YEAR
\end{tabular}

March 1997

4. FIN OR GRANT NUMBER E8238

Technical

7. PERKOD COVERED (Inclusive Datwos)

8. PERFORMING ORGANIZATION - NANE AND ADDRESS (INNRC, provide Division, Ofice or Region, U.S. Nucloer Regulatory Commission, end meiting edtrass; if contractor, provide name and melling eddrass.)

Idaho National Engineering Laboratory

Lockheed Martin Idaho Technologies Company

P.O. Box 1625

Idaho Falls, ID 83415

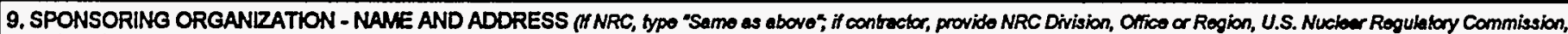
and mailing addrass.)

Safety Programs Division

Office for Analysis and Evaluation of Operational Data

U.S. Nuclear Regulatory Commission

Washington, DC 20555-0001

10. SUPPLEMENTARY NOTES

E. J. Brown, NRC Technical Monitor, E. A. Trager, NRC Project Manager

11. ABSTRACT (200 words or loss)

Review of industry efforts to manage thermal fatigue, flow-accelerated corrosion, and steam generator water hammer damage to Pressurized Water Reactor (PWR) feedwater nozzles, piping, and feedrings is presented in this report. The review includes an evaluation of design modifications, operating procedure changes, augmented inspection and monitoring programs, and mitigation, repair and replacement activities. Four specific actions were taken to perform the evaluation (a) review of field experience to identify trends of operating events; (b) review of the related technical literature; (c) visits to three PWR plants and a PWR vendor, and (d) solicitation of information from foreign utilities. Our assessment of field experience indicates the USNRC licensees have apparently taken sufficient action to minimize the feectwater nozze cracking caused by thermal fatigue, wall thinning of $J$-tubes and feedwater piping, and steam generator water hammer in both top-feed and preheat steam generators. A major finding of this review is that the analysis, inspection, monitoring, mitigation, and replacement techniques have been developed for managing thermal fatigue and flow-accelerated corrosion damage to feedwater nozzles, piping, and feedrings. Adequate training and appropriate applications of these techniques would ensure effective management of this damage. Several PWR plant operators have been proactive in managing this damage.

12, KEY WORDSIDESCRIPTORS (List words or phrases that will essist rosowchers in locating the report)

Pressurized water reactor feedwater nozzle, piping, feedring, J-tubes, flow stratification, thermal fatigue, flow-accelerated corrosion, erosion-corrosion, inspection and monitoring, field experience, water hammer

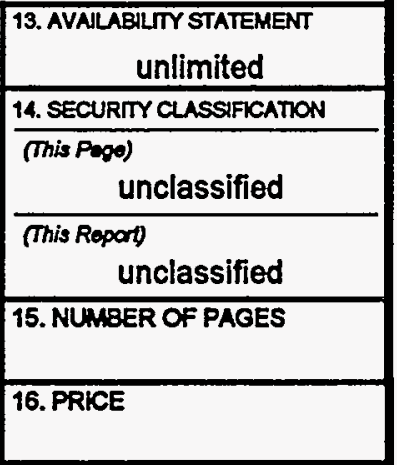

